\title{
IntechOpen
}

\section{Promotion and Marketing Communications}

Edited by Umut Ayman and Anul Kemal Kaya

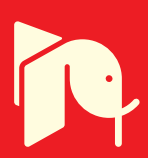





\title{
Promotion and Marketing Communications
}

\author{
Edited by Umut Ayman \\ and Anul Kemal Kaya
}



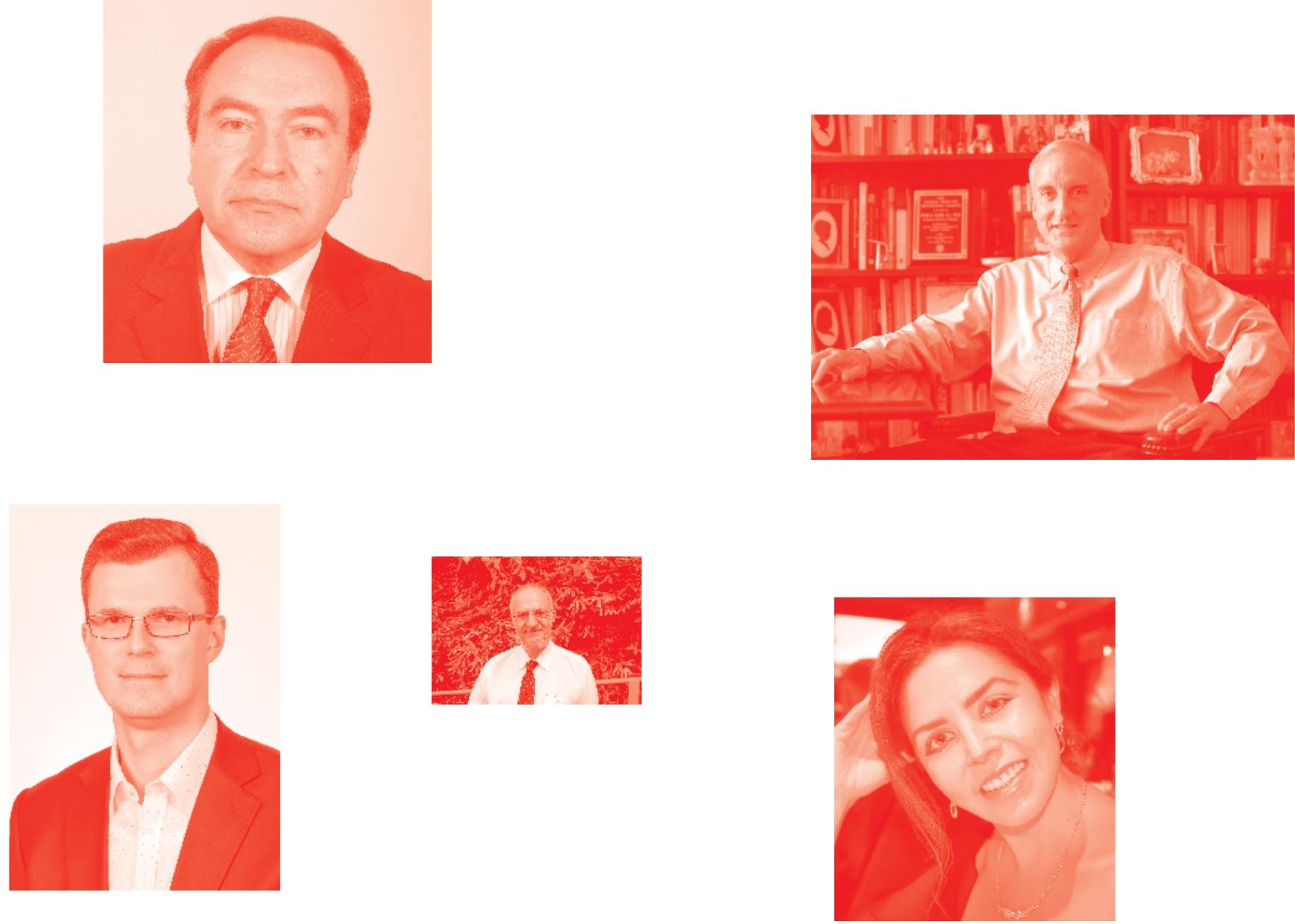

Supporting open minds since 2005
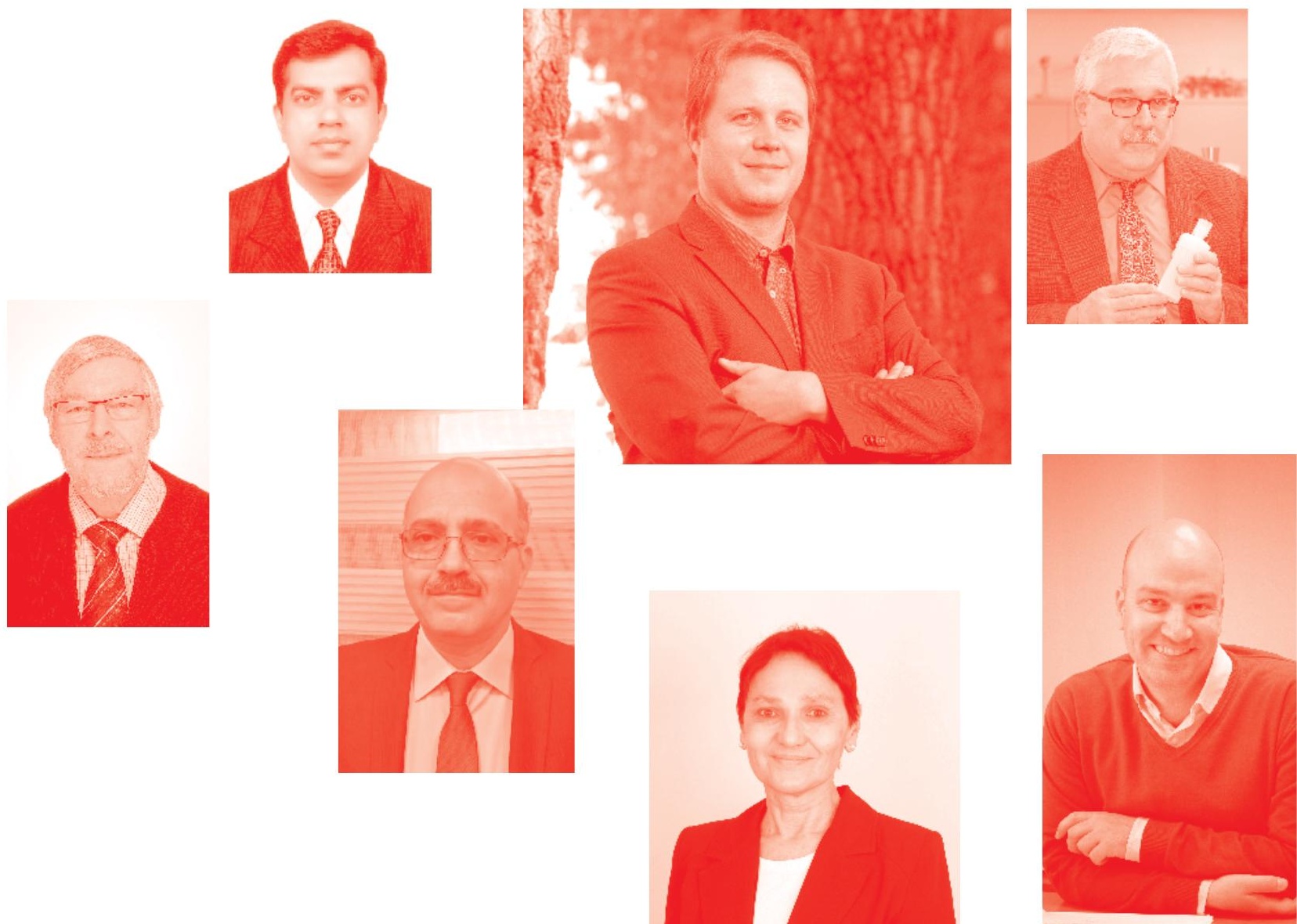
Promotion and Marketing Communications

http: //dx. doi. org/10.5772/intechopen . 83011

Edited by Umut Ayman and Anıl Kemal Kaya

Contributors

Rouxelle De Villiers, Pornchanoke Tipgomut, Drew Franklin, Aykut Ekiyor, Fatih Altan, Sumitro Sarkum, Ilko Getov, Stefan Balkanski, Diana A. Filipescu, Noelia Jiménez-Asenjo, Carlos Gonzalo-Penela, Umut Ayman, Anıl Kemal Kaya, Arooj Rashid, Peter Markovič, František Pollák, Peter Dorčák, Chandan Kumar Mishra

๑) The Editor(s) and the Author(s) 2020

The rights of the editor(s) and the author(s) have been asserted in accordance with the Copyright, Designs and Patents Act 1988. All rights to the book as a whole are reserved by INTECHOPEN LIMITED . The book as a whole (compilation) cannot be reproduced, distributed or used for commercial or non-commercial purposes without INTECHOPEN LIMITED's written permission. Enquiries concerning the use of the book should be directed to INTECHOPEN LIMITED rights and permissions department (permissions@intechopen.com).

Violations are liable to prosecution under the governing Copyright Law .

\section{(cc) BY}

Individual chapters of this publication are distributed under the terms of the Creative Commons Attribution 3. 0 Unported License which permits commercial use, distribution and reproduction of the individual chapters, provided the original author(s) and source publication are appropriately acknowledged. If so indicated, certain images may not be included under the Creative Commons license. In such cases users will need to obtain permission from the license holder to reproduce the material. More details and guidelines concerning content reuse and adaptation can be found at http : //www . intechopen . com/copyright-policy . html .

\section{Notice}

Statements and opinions expressed in the chapters are these of the individual contributors and not necessarily those of the editors or publisher. No responsibility is accepted for the accuracy of information contained in the published chapters. The publisher assumes no responsibility for any damage or injury to persons or property arising out of the use of any materials, instructions, methods or ideas contained in the book.

First published in London, United Kingdom, 2020 by IntechOpen IntechOpen is the global imprint of INTECHOPEN LIMITED, registered in England and Wales, registration number: 11086078, 7th floor, 10 Lower Thames Street, London,

EC3R 6AF, United Kingdom

Printed in Croatia

British Library Cataloguing-in-Publication Data

A catalogue record for this book is available from the British Library

Additional hard and PDF copies can be obtained from orders@intechopen.com

Promotion and Marketing Communications

Edited by Umut Ayman and Anıl Kemal Kaya

p. cm.

Print ISBN 978-1-83880-227-1

Online ISBN 978-1-83880-228-8

eBook (PDF) ISBN 978-1-78984-699-7 


\section{We are IntechOpen, \\ the world's leading publisher of Open Access books}

\section{Built by scientists, for scientists}

\section{$4,900+$ \\ Open access books available \\ $123,000+$ \\ International authors and editors \\ $140 \mathrm{M}+$ \\ Downloads}

151

Countries delivered to

Our authors are among the

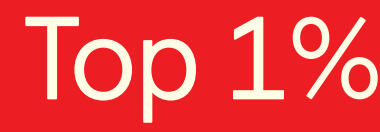

most cited scientists

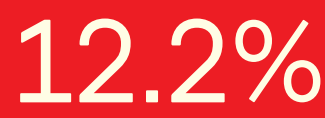

Contributors from top 500 universities

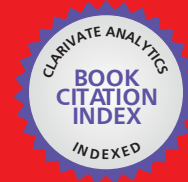

WEB OF SCIENCE ${ }^{\mathrm{M}}$

Selection of our books indexed in the Book Citation Index in Web of Science ${ }^{\mathrm{TM}}$ Core Collection (BKCI)

Interested in publishing with us?

Contact book.department@intechopen.com

Numbers displayed above are based on latest data collected.

For more information visit www.intechopen.com

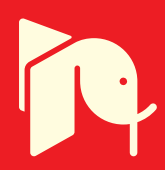





\section{Meet the editors}

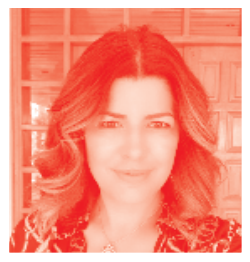

Umut Ayman completed her Bachelor's degree in Business at the Eastern Mediterranean University (EMU) and completed her MBA in 1999. Within the EMU Community Involvement Center, Ayman pioneers and provides consultancy services for social responsibility projects. She completed her Communication and Media studies PhD in 2015 and in her thesis she focused on consumption patterns in branded apparel products, its communication and consumers' decision-making styles from a marketing communication perspective. She also works on campaign designs and launches for products/services for various sectors and is involved in $\mathrm{A}$ to $\mathrm{Z}$ integrated marketing communication models including luxury consumption, branding, and fashion marketing communication issues. She lectures on an introduction to marketing communication, integrated marketing communication, marketing oriented public relations, marketing communication for social responsibility, IMC research methods, fashion marketing communication, branding and brand management, IMC campaign, and senior project courses. She is working as an Assistant Professor and Vice-chair at EMU, Faculty of Communication, Public Relations and Advertisement Department.

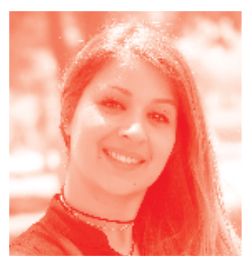

Anıl Kemal Kaya is an Associate Professor in the Public Relations and Advertising Department in the Eastern Mediterranean University, North Cyprus. She has been Chair of the Public Relations and Advertising Department in the Communication Faculty since 2016 and Chair of the Community İnvolvement Center in the Eastern Mediterranean University since 2013. Her research interests are integrated marketing communication, marketing communication, advertising, public relations, consumer behavior, brand management, strategic communication, and women studies. She has many publications in index journals and international conference papers. Currently she is researching her field topics, lecturing both undergraduate and graduate level in Integrated Marketing Communication, Marketing Communication Campaign Design, Strategic Communication, and Advertising. Also, she supervises many MA theses and $\mathrm{PhD}$ theses on Marketing Communication, Branding, Public Relations, and Advertising. For many years she has supervised many social responsibility projects at the Eastern Mediterranean University. 



\section{Contents}

Preface

Section 1

Marketing Communication in Real Sector Investments

Chapter 1

International Market Segmentation across Consumption and Communication Categories: Identity, Demographics, and Consumer Decisions and Online Habits

by Rouxelle de Villiers, Pornchanoke Tipgomut and Drew Franklin

Chapter 2

Repositioning of PR Field in Developing Countries by Anul Kemal Kaya and Umut Ayman

Chapter 3

Reputation Management

by František Pollák, Peter Dorčák and Peter Markovič

\section{Section 2}

Inevitable Digitalization

Chapter 4

E-Detailing: Keyways for Successful Implementation of Digital Technologies in the Pharmaceutical Marketing by Stefan Balkanski and Ilko Getov

Chapter 5

Cheers in UK: How Visible Are Spanish Sparkling Wines on Google.co.uk?

by Carlos Gonzalo-Penela, Noelia Jiménez-Asenjo and Diana A. Filipescu

Chapter 6

Digital Marketing: Scope Opportunities and Challenges by Chandan Kumar Mishra 
Section 3

Sectoral Developments

Chapter 7

Dissecting Changes in Consumer Characteristics through

Psychographics

by Sumitro Sarkum

Chapter 8

The Media Effect: Implications for Manifesting Maintainable Body Image in the Context of Global Fashion Industry

by Arooj Rashid

Chapter 9

173

Marketing Communication and Promotion in Health Services by Aykut Ekiyor and Fatih Altan 


\section{Preface}

This edited Promotion and Marketing Communications book is an original volume that presents a collection of chapters authored by various researchers and edited by marketing communication professionals. There are three main sections: Marketing Communication in Real Sector Investments, Inevitable Digitalization, and Sectoral Developments. In total, the book has nine chapters categorized in sections with each having three chapters that involve theoretical exploratory and empirical analysis. To survive in the competitive world, companies feel an urge to achieve a competitive advantage by applying accurate marketing communication tactics. Understanding marketing communication is an essential aspect for any field and any country. Hence, in this volume there is the latest research about marketing communication under which marketing strategies are delicately discussed. This book does not only contribute to the marketing and marketing communication intellectuals but also serves different sector company managerial positions and provides a guideline for people who want to attain a career in this field giving them a chance to acquire the knowledge regarding consumer behavior, public relations, and digital marketing themes.

Umut Ayman and Anıl Kemal Kaya

Eastern Mediterranean University,

North Cyprus 

Section 1

\section{Marketing \\ Communication in Real Sector Investments}





\title{
International Market
}

Segmentation across Consumption and Communication Categories: Identity, Demographics, and Consumer Decisions and Online

\section{Habits}

\author{
Rouxelle de Villiers, Pornchanoke Tipgomut \\ and Drew Franklin
}

\begin{abstract}
In this chapter we will discuss the different approaches to market segmentation and selection and explore how the selection process influences the company's culture, its brand positioning, and how it is impacted upon by the overall marketing and communication strategy and vice versa. Some questions this chapter considers and discusses are: Which segments should firms' international marketing activities (including financial, human resources, and the firm's capabilities) focus on? How do multinationals decide if segmentation efforts are effective? Finally, we will explore how organizations ${ }^{1}$ can monitor and control the various activities and outcomes, in order to ensure sustainable competitive advantage(s) in a highly competitive marketplace and online marketspace.
\end{abstract}

Keywords: brand alignment, consumption categories, niche communication, positioning, selection, SCA, segmentation

\footnotetext{
${ }^{1}$ Note that we use the terms "firms,"” organizations," "multi-nationals," and "businesses" interchangeably in this chapter. We do not refer to the vendors' legal ownership structures when we use these terms but merely wish to differentiate the collection of individuals jointly called vendors or sellers, from individual, nonaligned entrepreneurs or small business owners. Although we use the term "marketers" for the marketing professionals in these firms, they might have alternative official titles and roles such as CEO, VP Marketing, sales manager, business development manager, customer acquisition and retention officers, sellers, etc.
} 


\section{Introduction}

\subsection{Marketing as a process to ensure needs satisfaction}

The global marketplace is highly competitive. In these hyper-competitive marketplace manufacturers, distributors and marketers trade goods and services for money, time, testimonials, information, and referrals from consumers across country borders. For organizations (representing manufacturers and other stakeholders in the distribution and sales of products) to most suitably develop/focus their product and service offerings on satisfying the unique needs and demands of a variety of prospects and consumers, marketers divide the market into groups, called segments. Understanding the needs and wants of a select group of consumers is imperative to sustainable business success in this hyper-competitive space. Marketing is the process of identifying and studying consumers' dynamic needs, thus enabling marketers to create, capture, and communicate offerings that represent value to customers, clients, and society at large. Marketing communication aims to deliver value exchange between the marketing entities and consumers [1]. The exchange between an organization (a person, firms, retailers, wholesalers, NGOs, governments, associations, industries) and a consumer (individual customer or business buyer) will only take place if the offering (product, service, idea, knowledge, information, experience) is seen as "of value" to the prospective buyer(s). Also, an acceptable level of trust needs to exist between the parties involved in the exchange. Therefore, good marketing communication that delivers an exchange that satisfies both parties (buyer, seller, and other stakeholders), requires a clear vision, thoughtful planning, and well-targeted activities. To offer genuine value to current and future customers, the overall market is segmented into categories of consumers with fairly similar, homogeneous needs and wants, similar access points and of whom engage with similar communication channels to gather product knowledge and information. Several segmentation models exist, and we will discuss those later in this chapter.

"Marketing is aimed at satisfying customer needs and wants".

Consumers are only likely to purchase products and services (combined we call them offerings) that satisfy conscious needs and wants or when awareness of offerings results in impulsive buying due to perceived value or perceived benefits. These needs and wants become demands when consumers have both the intention to purchase an offering and the money to turn their wants into a purchase-often of a very specific (sometimes branded) product or service. Needs may range from physiological needs like thirst and hunger to psychological needs such as acceptance to a particular group. Hedonic needs and desires such as aspiring to be recognized as a top achiever may also impact consumers' decisions. For example, some consumers may buy a leather case for its functionality durability (functional needs), while others may buy a leather briefcase to fit into their professional dress code (social needs), while another group of briefcase buyers may simply buy it for the implied status of and recognition that comes with carrying an expensive (a hedonic need to indicate status), Louis Vuitton briefcase.

"Two basic types of information needs: functional needs and hedonic needs. Utilitarian needs are those linked to the function of the product, service, or good 
being purchased (e.g., a lawnmower must cut tough tufts of grass well). Hedonic needs refer to the emotional and psychological needs of the various consumers (e.g., fantasies, ambitions, aspirations)".

\title{
1.2 Segmenting, targeting, and positioning in the consumer market
}

A segmenting, targeting, and positioning (STP) plan starts with the organizations' overall strategy. A clear understanding and articulation of the organizations' mission and objectives are essential to a worthy-to-follow STP. As an example, the Swedish car manufacturer Volvo's mission is "Our solutions to global challenges are driven by our mission to drive prosperity through transport solutions" [2]. Further, an investigation into and adaptation of the plan to suit the context within which it competes is necessary.

"Understanding the environment within which the firm operates is called contextual intelligence $=$ CiQ”.

This contextual intelligence is also called a SWOT analysis. A SWOT analysis is based on evidence about the strengths, weaknesses of the resources, capabilities, and competencies within the organization and the opportunities and threats of the political, economic, social, technological, legal, and natural environment external to the organization [3]. For example, marketers bringing out an electronic vehicle (EV) will benefit from knowing if the government will support the necessary hosts of new charging stations; what additional features consumers may expect; what consumers' attitudes are towards environmental issues as they relate to EVs; and what pricing and promotion strategies competitors are likely to adopt these innovative cars [3].

Segmenting the market into niche groups in order to identify large and profitable market segments is imperative to new firms and new products, before many competitors select their preferred market segments. Coke No Sugar CNS (no sugar, original taste, also called $Z E R O$ in some markets) offered Coca-Cola an opportunity to market ZERO to a large new market segment, namely, healthconscious men [4]. But Coca-Cola's mainstream competitor, Pepsi, and other smaller competitors (e.g., diet Schweppes), responded with similar no-sugar, lowcalorie fizzy drinks such as Pepsi Max that may potentially turn this opportunity into a threat.

\begin{abstract}
"Segmentation is a way to cut the larger population into smaller groups or categories of people with similar needs, wants, and demands. Adept marketers also consider lifestyles (value of the product to their way of life) and product usage (how compatible the product is to their way of life and other purchasing choices)".
\end{abstract}

So another tool in the marketers' toolkit to create awareness, interest, and desire for their product offering ${ }^{2}$ (the solution for a consumers' problem) in order to create actions (sales, reviews, membership, etc.) is to diversify the offering to suit different market segments. Similarly, organizations will need to decide how to diversify the marketing channels to target (focus resources and efforts) each different audience (niche segment) they wish to attract and, ultimately, engage with

${ }^{2}$ AIDA model $=$ attention, interest, desire, and action 
as loyal customers (firms move customers from prospects to engaged customers and ultimately to loyal clients-the latter is also called fans or supporters). With the growth of social media (communication facilitated by online and mobile media) as an information search and communication channel for consumers, it is fast becoming an integral component of any integrated marketing communication (IMC) plan. Marketers apply the 4-E framework to think about the objectives of marketing objectives, aimed at various preselected and highly focused audiences: $\mathrm{E}_{1}=$ Excite, $\mathrm{E}_{2}=$ Educate, $\mathrm{E}_{3}=$ Experience, and $\mathrm{E}_{4}=$ Engage (Figure 1).

To excite a prospective buyer or consumer, the offer has to be relevant to them and be seen to be of some value, in other words, a worthy solution to some problem or issue they perceive (e.g., a problem could be that they want to upgrade their phone to a later model with a better camera and a longer lifetime for the battery of their mobile device). The relevancy can be improved by studying the needs of a particular target audience and personalizing the firm's offering to suit their needshopefully, better than those offered by direct and indirect competitors. (Indirect competitors solve the same problem, but not necessarily with the same product. For example, Disprin can reduce headaches, as does Advil and Tylenol. But an indirect competitor might be a physiotherapy session or even acupuncture as they may also reduce the customer's headache, but they are not chemical medicines in tablet form and dispensed over the counter.) To personalize ${ }^{3}$ offers, insights are gained using online data gathering and analysis tools such as Google Analytics, a listening system such as Radian6, or current customer information from databases such as Act or Salesforce CRM [5].

"Marketing is an exchange of value between customers and marketers. This exchange will only take place if there are trust and value between the two parties of the exchange. To personalize or customize an offer is likely to lead to better alignment of perceived and real value and therefore more sales".

One way to engage various audiences is by positioning your offering or brand as a particular solution, so those prospective buyers will think of your brand as a solution, or particularly valuable, relative to their needs. A firm's positioning within a target audience's mind is how and what they think about your brand when your communication cuts through the various channels to reach them and more importantly why the marketers' offerings are going to meet their respective needs better than other competitive offerings. For example, Volvo's core activity is the production, distribution, and sale of trucks, busses, and construction equipment [2]. Volvo is positioned in the automotive market (buyer need: mobility) as a safe and reliable car, whereas $B M W$ in contrast is positioned as a car for the driving enthusiast, with their well-known slogan "designed for driving pleasure" addressing these buyers' needs [6]. According to authors Al Ries and Jack Trout [7], creating a unique new category might be profitable, especially when a strong leading brand already occupies a large section of the market for that particular offer. A good example is K-Pop bands, who are taking the music market (even in the USA and Europe) by storm. K-pop is a genre of popular music originating in South Korea, aimed at young adults. The boy band BTS is a recent global phenomenon, using a combination of heavy pop, hip-hop, and emotional appeal with a sense of authenticity plus clever multimedia marketing to promote their albums. They are the first non-USA band

\footnotetext{
${ }^{3}$ Personalization (verb: to personalize) is the optimizing of experiences and messages to individuals themselves, not the grouping or sub-segment they belong to.
} 


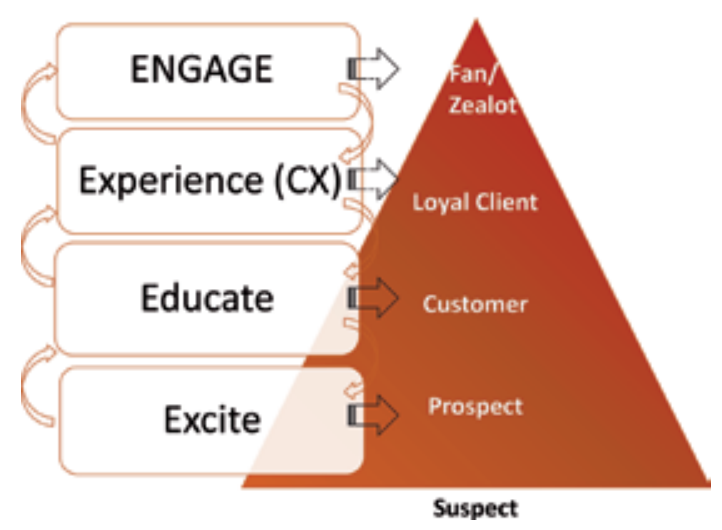

Figure 1.

The 4 E-framework using integrated marketing communication channels.

to appear on the US Top 200 charts for a number of weeks. Their studio has created an entirely new music segment where they can rule the air waves (and young adults' hearts and minds). According to Vox News [8], the reason why BTS broke the culture barrier to succeed in the USA is market driven. "The answer lies in a combination of factors, and most of them are about change: the changing nature of K-pop's studio culture and the way "idols" are produced; changing depictions of masculinity in South Korea; changing ranges of acceptable expression in K-pop; and, above all, the approach BTS has taken to building its fan base and interacting with its fans."

A way marketers set the offering/product apart from competitors is to establish a new product category that differentiates them clearly and positions them in a new way with modified, improved benefits for certain customers. For example, marketers for a new soft drink, filled with additional vitamins and energy boosters (such as guarana, taurine, or caffeine), position the sugary soft drink as an "energy drink," in contrast to a regular soda. (e.g., Red Bull is the leading brand in the energy drinks category, whereas Coke Cola or Pepsi may be the leading soda in the same consumer market).

\section{Market segmentation}

Buyers differ in their needs, wants, and demands. Marketers further differentiate between buyers and segment them into smaller segments that are fairly homogeneous in terms of either needs, resources, locations, buying attitudes, or buying practices. The main purpose of segmentation activities are to ensure that potential and current customers can be reached more effectively and that communication, product, and service offerings can be matched to the unique needs of the different buyers. A market segment is defined as a group or category of customers who can be reached with a distinct and differentiated marketing mix. Marketers create segments likely to react somewhat similarly to a unique mix of the marketing and promotional tools available to the firm, namely, product, price, promotion, place, people, physical evidence, processes, and partners (influencers and stakeholders). In this section of the chapter, we will discuss four segmentation topics: segmenting consumer markets, segmenting business markets, segmenting international markets, and segmenting online market. In Section 3 we discuss the requirements 


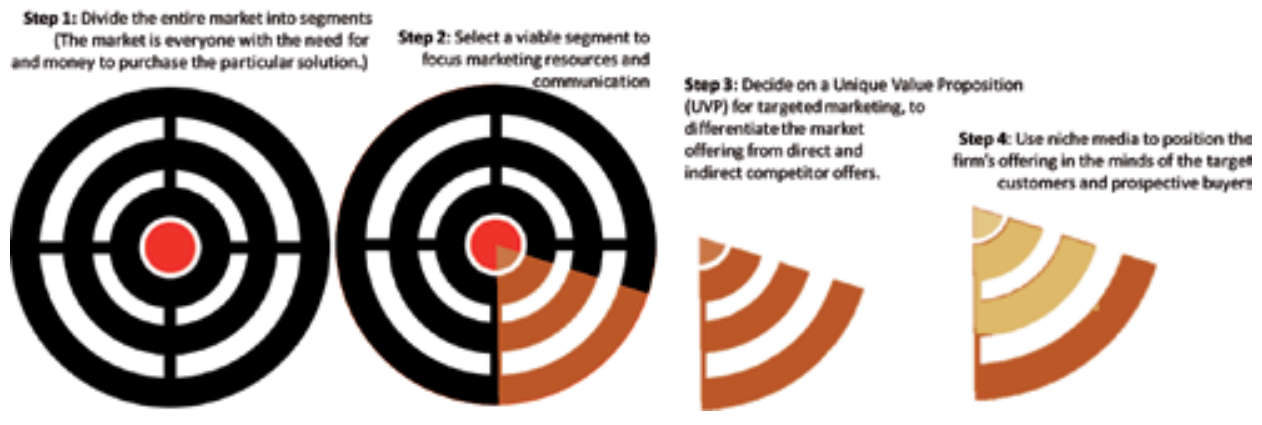

Figure 2.

Designing a market segmentation plan (MSP).

for effective market segmentation plans (MSPs) and how adept marketers monitor and control segment data to ensure sustainable competitive advantages (SCA) (Figure 2).

\begin{abstract}
"The central question for any marketing plan is: WHO? Who will we serve? Who is most likely to perceive our offering as a valuable solution for a problem they might have? Who will have the money, authority, and desire to buy from our firm?"
\end{abstract}

\title{
2.1 Segmenting consumer markets
}

\subsubsection{Bases to create consumer categories: consumer segmentation}

Consumers differ in many aspects, even when they share the same need or if they are searching for a solution to the same problem. Prospective buyers differ in what they are willing to pay (and other limited resources such as time, willingness, or ability to travel to buy an item) and buying attitude (these may vary from hostile to an active, engaged fan or supporter) to buying practices (impulse buying via shopping channels, low involvement shopping via online channels, unplanned buying in retail outlets, and high involvement searches of authoritative information before active retail searches of a very specific product or service).

As market segmentation involves subdividing the market into distinct subgroups that can be served with a distinct marketing mix [9], there are many ways to segment any market, but all of the segmentation approaches start with four basic questions. (1) Who has a need or desire for our service/product/offering (need or desire)? (2) Do they have the discretionary budget or money to afford the product or service in any of the various forms (or do we have to/wish to adapt our pricing strategy to serve the target audiences?) (money)? (3) Who is the decision-maker or has the authority to approve this purchase (authority)? If we concentrate efforts on these consumers as a group, (4) do they have distinctive needs, habits, and attitudes to be able to approach and serve them as a group or segment (Distinctive)? These four questions deliver the acronym MADD. The MADD model helps marketers to divide the larger market into groups of buyers who might require separate products or marketing and communication mixes. The last D in MADD provides some way to predict how the vendor can differentiate to offer distinguishable, relevant, and superior customer value.

There is no single approach to follow, but a range of likely segmentation opportunities are sought by considering main segmentation variables, i.e., geographic, demographic, psychographic, and behavioral characteristics. For geographic segmentation, a large population of prospective consumers is divided into clusters of 
geographical concentration, such as nations, states, provinces, regions, cities, and suburban, even down to postal code areas or neighborhoods. For some offerings, climate and city size or population density might be key to successful categorizing of prospective buyers. When marketers use demographic segmentation approaches, they consider clusters or groups based on gender, age, life cycle stage (unmarried, married, retired) and income, education, occupation, religion, and family life cycle (no children, with children, empty nest-married but adult children) [10]. For psychographic segmentation, different groups of different socioeconomic status or lifestyle groupings such as conventional family life, a fairer deal, basic needs, visible achievement, etc. are considered. A key indicator for lifestyle in a variety of products aimed at hedonic needs or addressing status and exclusivity desires of consumers is personality. Personality traits, such as ambitiousness, openness, conscientiousness, sophistication, compulsiveness, etc., are considered during marketers' segmentations decision. Behavioral characteristics include benefits sought (a wide range including service, quality, financing, performance); purchase occasion (regular or special occasions); usage rate (light, medium and heavy users); user status (non-user, orphan/past/lost users, first-time user, regular user); buyer readiness (unaware, aware, informed, interested, desirous, intention to buy); attitude towards the firms' offerings (hostile; negative, indifferent, positive, enthusiastic); and loyalty (skeptic, none/indifferent, mid-level, strong, supporter/ fan). Lastly, these behavioral aspects may also be linked to the online behavior of prospective customers. This may range from their likelihood to accept innovations to their online search behavior and their willingness to search for information and follow influencers or to act as influencer offering reviews and promoting the firms' offerings to their circle of influence. We discuss online segmentation in more depth in Section 2.4 (Table 1).

\subsubsection{Multivariate segmentation}

It is most often necessary to use multiple geographic and demographic segmentation variables in combination with each other to ensure access, differentiation, and a useful model to predict behavioral responses to the firms' marketing communication and marketing efforts. To ensure precise and viable categories with fairly homogeneous needs and access channels, marketers use multivariate segmentation. For example OurDeal, a direct competitor of the well-established Groupon, that offers discount deals to the mass market, via Channel Ten TV, carefully uses both geographic and several demographic variables to focus their offers [11, 12]. OurDeal CEO and founder Julian Holman says: "TEN is the undisputed leader in the under50s market and this means OurDeal merchants can extend the reach of the existing OurDeal online and social media outreach activity through the power of mass marketing television and online advertising."

\subsubsection{In pursuit of 1:1 marketing}

The ultimate aim of targeted marketing is highly customized offers and highly personalized marketing communication. Adept marketers suggest that personalized interactions nurture loyalty, greater engagement, and thus better return on marketing investments [13]. One-on-one (also written as 1:1 marketing) relies on understanding the unique preferences, behavior, and decisions of individual consumers and then adapting the marketing offers of the firm to ensure preference or choice in favor of the marketers' brand or offering. The personal tastes and preferences rely on very accurate knowledge of the consumer, to the point where the product and service are so highly adapted to the individual's need, that he/she feels 


\begin{tabular}{|c|c|c|}
\hline $\begin{array}{l}\text { Segmentation } \\
\text { variable }\end{array}$ & Typical breakdown & Examples and comments \\
\hline $\begin{array}{l}\text { Benefits } \\
\text { sought }\end{array}$ & $\begin{array}{l}\text { Marketers offer a range of benefits } \\
\text { that may address a particular need, } \\
\text { or range of needs, for consumers. } \\
\text { These additional benefits may include, } \\
\text { among others, services (e.g., B\&B } \\
\text { with or without washing and ironing), } \\
\text { quality (e.g., leather or pleather bags), } \\
\text { financing (e.g., car purchases with } \\
\text { lease or 48-month financing options), } \\
\text { and performance (cars with ABS and } \\
\text { 4-wheel drive, DOHC functions) }\end{array}$ & $\begin{array}{l}\text { Qantas offers a range of flight offers for } \\
\text { air travelers, ranging from price-sensitive } \\
\text { travelers (who are likely to fly no-frills } \\
\text { economy class) to full-service extra } \\
\text { comfort business class with more personal } \\
\text { space and the ability to sleep flat } \\
\text { Colgate offers "whitening," "herbal," } \\
\text { "sensitive," and "fresh breath" toothpaste } \\
\text { options to address the various benefits } \\
\text { sought by consumers } \\
\text { Mobile phone brand Samsung offers } \\
\text { different screen sizes, lens quality and } \\
\text { zooming ability, battery lifespan, and } \\
\text { other features that relate to benefits } \\
\text { sought, such as using the phone as a mobile } \\
\text { office, as a camera, and in traveling long } \\
\text { distances }\end{array}$ \\
\hline $\begin{array}{l}\text { Purchase } \\
\text { occasion }\end{array}$ & $\begin{array}{l}\text { The purchase occasion links to when the } \\
\text { idea to buy occurs or when the actual } \\
\text { purchase will be made OR when the } \\
\text { product will be used }\end{array}$ & $\begin{array}{l}\text { Hallmark cards for special holiday such } \\
\text { as Valentine's day, Mothers' Day, and } \\
\text { Christmas or “Get well” cards. } \\
\text { L'Oreal makeup for everyday use; special } \\
\text { events; evening glamor; sensitive skins; } \\
\text { refreshing after late nights or illness }\end{array}$ \\
\hline User rate & $\begin{array}{l}\text { User rate refers to consumers that are } \\
\text { either light, medium, or heavy users }\end{array}$ & $\begin{array}{l}\text { In most industries, approximately } 80 \% \\
\text { of the business comes from about } 20 \% \\
\text { of consumers-in some cases as high as } \\
95 \% \text { comes from } 15 \% \text { of consumers. So, } \\
\text { it is important to provide the products } \\
\text { and services those clients buy. E.g., if an } \\
\text { ice cream store (e.g., Wendy's) runs out } \\
\text { of chocolate or vanilla flavor, they will } \\
\text { quickly react by refilling these flavors, } \\
\text { while, should a flavor like pistachio or } \\
\text { rum run out, consumers are likely to } \\
\text { simply purchase another favorite. In } \\
\text { contrast, should a consumer want a } \\
\text { chocolate ice cream, they may purchase } \\
\text { from the store's closest competitor } \\
\text { rather than select the next best option in } \\
\text { the store }\end{array}$ \\
\hline User status & $\begin{array}{l}\text { Firms record user status on their CRM } \\
\text { or customer databases to determine } \\
\text { which type of marketing tactics they } \\
\text { should employ to increase their share } \\
\text { of wallet (\% of business from this } \\
\text { customer) and market share. Status } \\
\text { varies from nonusers to potential, } \\
\text { first-time, and regular users. Past, } \\
\text { lapsed, or ex-users (also called orphans } \\
\text { within the firm) are customers who } \\
\text { may have bought from the firm but no } \\
\text { longer do so }\end{array}$ & $\begin{array}{l}\text { The marketing strategy of start-ups may } \\
\text { be to attract new users and retain them } \\
\text { as regular users, while well-established } \\
\text { businesses are likely to pursue recurring } \\
\text { business from existing customers, } \\
\text { re-interest lapsed customers, and poach } \\
\text { clients from competitors } \\
\text { Many firms spend a large portion of } \\
\text { their marketing budget and resources on } \\
\text { retaining, cross-selling, and up-selling } \\
\text { existing customers. This is a cost-effective } \\
\text { strategy, since past purchasers have } \\
\text { indicated their interest in and desire for } \\
\text { the firm's offerings. Adept marketers also } \\
\text { try to regain interest from lapsed or past } \\
\text { users or determine why they have left, to } \\
\text { see if the firm can improve their retention } \\
\text { rate and keep current and future customers } \\
\text { satisfied }\end{array}$ \\
\hline
\end{tabular}


International Market Segmentation across Consumption and Communication Categories... DOI: $h$ ttp://dx.doi.org/10.5772/intechopen.89988

\begin{tabular}{|c|c|c|}
\hline $\begin{array}{l}\text { Segmentation } \\
\text { variable }\end{array}$ & Typical breakdown & Examples and comments \\
\hline $\begin{array}{l}\text { Buyer } \\
\text { readiness }\end{array}$ & $\begin{array}{l}\text { Consumers are at various stages of } \\
\text { readiness: unaware of the firm's offering; } \\
\text { aware; informed, interested, desirous; } \\
\text { or already have the intention to buy- } \\
\text { thus fully ready }\end{array}$ & $\begin{array}{l}\text { When a new product is launched into } \\
\text { the marketplace, for example, an electric } \\
\text { vehicle (EV), say Range Rover's first priority } \\
\text { is to raise awareness and educate consumers } \\
\text { and potential buyers. In contrast, potential } \\
\text { buyers may be very aware and highly } \\
\text { informed of solar energy panels, but the } \\
\text { uptake and purchase levels are low. Thus, } \\
\text { entirely different marketing objectives and } \\
\text { tactics are required to communicate with } \\
\text { these various buyer-readiness segments }\end{array}$ \\
\hline Loyalty status & $\begin{array}{l}\text { The degree of loyalty to a brand and } \\
\text { their offerings may vary substantially } \\
\text { from a brand skeptic (negative feelings), } \\
\text { to neutral, indifferent, or no-loyalty, } \\
\text { to somewhat loyal (mid-level loyalty } \\
\text { status), to the ideal brand loyalty status } \\
\text { of fan/supporter/zealot }\end{array}$ & $\begin{array}{l}\text { Consumers can be loyal to products } \\
\text { (Google Maps) or brands (Coca-Cola and } \\
\text { Apple) or a store (Gap NY), a sales person } \\
\text { (Ray White estate agent), or a company } \\
\text { (General Life Insurance). Loyalty patterns } \\
\text { inform marketers about what appeals } \\
\text { to a particular market segment, and by } \\
\text { studying less-loyal customers, marketers } \\
\text { can learn about competitive offers and how } \\
\text { to adapt (or die). Marketers need to take } \\
\text { great care when studying loyalty, since } \\
\text { various contextual and personal factors } \\
\text { such as convenience, price sensitivity, and } \\
\text { product availability might impact loyalty }\end{array}$ \\
\hline $\begin{array}{l}\text { Attitude } \\
\text { towards the } \\
\text { firm's offerings }\end{array}$ & $\begin{array}{l}\text { Consumers can be placed on a } \\
\text { continuum of attitudes towards the } \\
\text { firm's offerings, ranging from hostile, } \\
\text { negative, and indifferent to positive and } \\
\text { enthusiastic }\end{array}$ & $\begin{array}{l}\text { Positive word-of-mouth (WOM) and } \\
\text { electronic WOM (eWOM) are very } \\
\text { valuable to marketers to build the } \\
\text { brand reputation and perception of } \\
\text { trust and value in prospective buyers. } \\
\text { Many companies monitor the social } \\
\text { media comments, rating, and reviews to } \\
\text { determine the attitude towards the brand } \\
\text { and its offerings. For example, FlightStar } \\
\text { (a travel agency) may adapt its tours to } \\
\text { exclude a particular hotel or destination if } \\
\text { many consumers give bad reviews or leave } \\
\text { negative comments on Twitter or Facebook } \\
\text { about these particular hospitality providers }\end{array}$ \\
\hline $\begin{array}{l}\text { Online } \\
\text { behavior }\end{array}$ & $\begin{array}{l}\text { Online behavior ranges from the } \\
\text { likelihood to accept innovations to } \\
\text { online search behavior; willingness } \\
\text { to search for information (level } \\
\text { of involvement); to willingness to } \\
\text { follow influencers and offer reviews; } \\
\text { willingness to promote the firms' } \\
\text { offerings to their personal circle of } \\
\text { influence (called advocacy) }\end{array}$ & $\begin{array}{l}\text { Marketers track individual's buying } \\
\text { behavior, including payment methods, } \\
\text { click-throughs, minutes spent on a page, } \\
\text { and influencers followed, to improve } \\
\text { search results and the likelihood to stumble } \\
\text { upon and/or reach the firm's online } \\
\text { advertisements or website. For example, a } \\
\text { consumer opening a picture of a particular } \\
\text { pair of jeans on Pinterest may be directed } \\
\text { to Levi's (jeans) website or a similar denim } \\
\text { jacket on Levi's site. A web-surfer looking at } \\
\text { scenic pictures of a particular destination, } \\
\text { say Italy, may be directed to travel products } \\
\text { (e.g., MSC Cruises to Italy). But they might } \\
\text { even be sent travel advertising at other } \\
\text { times, when they are on sites unrelated to } \\
\text { travel. }\end{array}$ \\
\hline
\end{tabular}

Table 1.

Behavioral segmentation approaches for consumer markets. 
treated like the marketers' only customer (hence 1:1). In today's highly automated and digital environment, most of this information about habits and behavior, personal choices, and interests are collected during the various interactions with the firm. For example, online searches and clickthroughs are recorded on Google Analytics; personal interactions with salespeople are recorded on CRM databases; purchasing and payment habits are recorded via electronic funds transfer (EFT) systems. The firm learns the preferences and customizes a marketing plan for them. Ideally each interaction will be highly customized to suit each customer, but this highly unique customized marketing mix may be rather costly, and thus the firm will have to maximize benefit (to both parties) and minimize cost. So, after a 1:1 marketing strategy, the next best and most viable option is to create segments of customers with very similar needs, habits, decision and choice patterns, access points, and lifestyle choices. Access to consumers' eyes, ears, and hearts is at the crux of good marketing strategies. Which channels can marketers use to communicate with their most likely prospective buyers? What should the message say to convince them to trust the brand? What should the message be to persuade them of the value of our offer? How should the firm best approach prospective customers to ensure their action and loyalty? These are the questions marketers have to ask to consider creating fairly homogeneous groups of prospects, customers, and loyal supporters.

Companies who continually listen to customers, improve their offerings, and stay competitive and relevant are likely to succeed in the hyper-competitive marketplace. The CEO of General Electric (GE), Jack Welch, once said: "we have only two sources of competitive advantage: the ability to learn more about our customers faster than the competition and the ability to turn that learning into action faster than the competition" [14].

\subsection{Segmenting business markets (B2B)}

Business-to-business marketing or B2B marketing is the marketing of products and services to a variety of organizations such as companies, government bodies, nongovernmental organizations (NGOs), and not-for-profit (NFP) businesses (such as schools, hospitals, libraries) and other firms. These may vary from small, single-person entrepreneurial firms, to family-operated local companies, retail chains, and franchisors, to large global conglomerates with various purchasing agents and complex decision-making procedures. In B2B marketing, buyers use the products and services they purchase, either to produce their own products and service offering, or use them in their daily operations, or use them to sell to other B2B customers. A university buys copiers, computers, mobile phones, books, desks, filing cabinets, and carpet, among other products, for their daily operations, while a research laboratory may buy chemicals, gas for burners, benches, white coats, copiers, mobile phones, and computers. A car manufacturer like BMW purchases pre-made seats and carpeting and some instruments like car radios and electronic dashboards to ensure a high quality interior that is both pleasing and functional [15] and compatible with drivers' current habits. As an example, the new BMW i3 includes Apple CarPlay in their dashboard to allow drivers' smartphones to interface with their vehicles, thus meeting current technology habits and needs of $B M W$ drivers. As another example, we specifically chose mobile phones to appear in two of the aforementioned lists, since it could be argued that all B2B products are also consumer products, since they are bought to be used by consumers with specific needs and purposes for these products. When one of the employees of the university or research lab buys a mobile phone 
for personal use, it is classified as a consumer product. But, even for an identical phone, the product is considered a B2B product (phone), when an employee uses it for work purposes. Buying motives for a business customer, though, is likely to differ from that of the individual end-user (consumer). For example, a consultant using his/her phone as a mobile office is likely to have different needs such as large memory, long battery life, and various pre-loaded office management software. In contrast a private individual consumer may be more interested in the quality of the camera and the media speakers than those criteria listed by business customers.

Organizational buying behavior is a complex combination of individual decisions and organizational buying processes and procedures. Although the final purchasing budget may belong to the organization, individuals may be procurement officers, users, and people with the power to veto a decision. A key characteristic of B2B buying behavior is that several individuals from different backgrounds, with different buying motive and different levels of decisionmaking power, may be involved in the buying decision. For example, the purchasing process for the research laboratory to buy new laboratory equipment may involve the lab technicians (functional needs), the maintenance staff (for cleaning), accounting (for budgeting and price setting), a legal advisor (for servicing contracts), and a business unit manager (opportunities to optimize resources and competitive advantages). This group is called the decision-making unit (DMU). Therefore, B2B marketing is mainly about relationships of trust and transactions between organizations as represented by individuals within the two trading organizations. As said earlier, marketing is about creating or adding value for consumers. Similarly, B2B marketing is helping business customers to be successful by delivering superior value to enable the DMU to produce their own valued products and services for their internal and external customers. Thus, just like in consumer marketing, the success of B2B marketing depends largely on marketers' understanding of what DMUs value and ideally understanding what each individual role player in the DMU values and the style and channel each member of the DMU prefers.

Marketers who sell to large international companies, or conglomerates with several divisions, business units (BUs), or plants, may subdivide the large customer as a set of sub-segments. In this case, the different SBUs with different needs and different buying behavior can be clumped together as segments, allowing each $\mathrm{BU}$ to be targeted using different marketing and promotional mixes and different communication channels and targeted messages. For this type of segmentation, large BUs are likely to receive highly personalized attention by key account managers to serve their unique needs, while regional offices and medium-sized BUs may be served by using regional sales teams. The small (or micro) accounts can be served via online order-taking systems or telemarking sales-and-support officers. An example of this is travel agents like ORBIT Travel. Their large corporate clients each have a dedicated key account manager (KAM) at their regional travel agencies, while smaller firms will deal with a team of specialists serving a particular niche (e.g., one B2B sales professional serve banking clients, while another may serve education institutions). Small business owners are treated in the same way as individual consumers, by asking them to either book online or visit the branch to make their bookings via any one of the available travel agents on site at the time of their booking.

B2B marketers combine use mainly three common approaches to segment business markets: the two-stage approach; the three-dimension approach; and the nested approach. We discuss them here: 


\subsubsection{Two-stage approach}

This approach, designed by Wind and Cardozo [16], combines customer firm characteristics such as size, industry, and product application with the nature of the decision-making processes of the BU. The first macro-segmentation step is to group firm of similar size, location, and industry together. For example, B2B marketers might group large corporate accounts, SMEs, and small customers into three separate clusters. A promotional signage company may, for example, segment their corporate clients into segments such as packaging, signage and displays, outdoor, vehicles, and trade shows OR by industry, e.g., healthcare, construction, beverages, printing, automotive, and fashion apparel. To ensure a competitive advantage, the next stage is to find clusters within the macrosegments that demonstrate similar buying behavior (micro-segments) or similar decision procedures by the DMUs. For example, within the cluster of healthcare professionals, large B2B customers have purchasing agents (BUs) that buy on behalf of five to ten franchisees, whereas pharmacists who manage their own small pharmacies act as their own marketing specialist and purchasing agent for their pharmacies. Where the large franchises use expensive point-of-purchase displays and window-dressing to communicate season offers such as cold remedies, the smaller pharmacies only use branded items offered for free by large pharmaceutical suppliers. Although this second sub-division of macro-segments into micro-segments offers insight into individual decision-making processes, this second stage is difficult (due to access to this type of information) and costly to collect (due to a long time it takes to learn about different practices and decisionmaking procedures).

\subsubsection{Three-dimensions approach}

The three dimensions to consider when executing the three-dimensions segmentation plan are customer groups (who), customer functions (what), and technologies (how) [17]. The customer groups dimension refers to the standard consumer/customer-based segmentation using demographics, geographic categories (e.g., province, state, nation, postal codes, suburbs), nature of the customer (e.g., academic, professional, sales organization, law firm, government, etc.), or product usage characteristics (DMU, first-time client, loyal customer, buying situation). Customer functions are related to the application or solution sought, e.g., for the travel industry, it might range from conference attendance, site inspection, convention, movie premiers and PR events, honeymoon, family holiday, sales award functions, etc. For the third dimension, the marketer considers how the product or service may be communicated, applied, best used, enhanced or distributed, and supported. For example, a book publisher might deliver hardcover printed books, or paperback, e-books, or part downloads. Returning to our travel example, prospective buyers may be divided into walk-in clients, call-in clients, online leads, outbound calls, corporate deals via key account managers (personal selling), and trade show sales (Figure 3).

\subsubsection{Nested approach}

In the B2B environment, Bonoma and Shapiro [18] suggest that marketers use a "nested approach" to segmentation. This approach consists of five segmentation categories with increasingly more detailed information about the buyer organization's buying behavior, set out below. It is important to note that the required information needs to be meticulously gathered to be as accurate as possible and therefore 


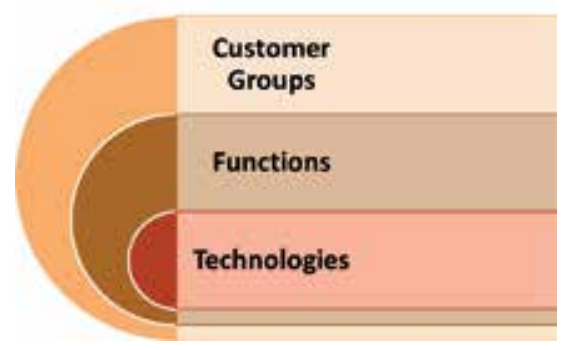

Figure 3.

Three-dimension approach to $B_{2} B$ segmentation

is often costly in time and resources. The more detailed, the costlier to gather. The information contained in each of the levels set out below gets more difficult to get accurate and thus more costly as you go down the list:

Demographics: industry, size, location, international spread-this information is easily obtained from various databases and other secondary (public or purchased) data sources.

Process characteristics: buyers' operations such as technology employed, type of product application (e.g., how they will apply/adapt the marketers' product or service) - this information is more difficult to come by but can often be found in annual reports and websites, through the sales representatives and via various forms of primary and secondary research.

Purchasing approach: buyers' specific processes and structures within the firm, as well as their procurement procedures and purchasing policies, should be determined through research but also personal relationship building experiences with potential and current clients.

Situational factors: a whole host of situational factors, including the size and urgency of the order(s), whether the order is a regular recurring order or an unusual ad hoc order or perhaps an entirely new client. Further considerations are, among others, the number of users and their experience with the product, the sales professional and support staff, and the trading firm.

Personal characteristics: motivation, risk profile, and relationship.

Although Bonoma and Shapiro suggest using all five levels in the nested approach, the authors advise firms to balance cost and rigor. But using all five levels ensures a systematic and hierarchical approach that will prevent marketers from missing relevant indicators to ensure distinctive, viable, and measurable market segments (Figure 4).

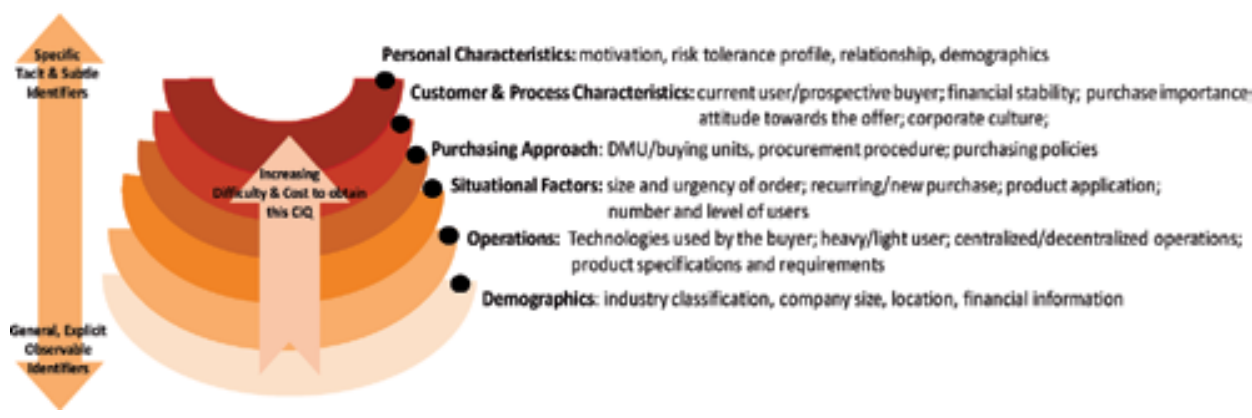

Figure 4.

Nested approach to $\mathrm{B}_{2} \mathrm{~B}$ segmentation (adopted from [18]). 


\subsection{International markets}

Exchanging products between countries, as a form of international marketing, has existed since the earliest recorded histories of mankind. A key factor affecting the need for international bartering and economic exchange is the uneven distribution of and access to natural resources across the globe [19]. For example, by far the largest producers of useable iron are Australia, Brazil, and China, who severally produce more than $75 \%$ of the world's useable iron ore [20]; India is the largest producer of mangos [21], and $\pm 70 \%$ of all wool exports come from Australia and New Zealand [22], and India is the top cotton producer in the world [23]. Technological advancements (including innovation in transport, information technology (IT), and business processes) have contributed to international trade and economic cooperation. Certain countries and some companies develop competitive advantages due to new efficiencies, new more cost-effective processes improved capabilities, or economies of scale and scope, thereby making their inventions or services (e.g., cheaper labor for telemarketing services) preferred. In some cases, beneficial trade agreements and political alliances result in increased trade between particular countries. With continuous, radical, and often disruptive improvements in data and telecommunications technology, opportunities for marketing communication, sales, and transferring data (money and information) continue to improve in quality and increase in quantity.

International markets concern attracting and servicing customers abroad-away from either the manufacturing or the main location of the organization's head office (HQ). International marketing can be binational (only one country away from local markets) or multinational (more than one country the firm may market to, away from $\mathrm{HQ}$ or manufacturing plants). For example, a multinational company like Coca-Cola sells in more than 200 countries, with the "Coca-Cola logo is recognized by $94 \%$ of the world's population" [24], while the global electronic company Samsung operates in 73 countries, with 39 production sites, 35 R\&D offices, and 7 design sites worldwide [25]. Operating in such a diverse set of nations obviously adds a whole host of complications. In addition, the mode of operation in various countries may take several forms, from servicing markets directly in foreign markets or indirectly through franchises, licensors, distributors, agents, or brokers or remotely via online providers and a host of supply chain members (including raw products, distribution - the case of Coca-Cola bottling plants; for Samsung assembly plants in partnership with FedEx, DHL and other express couriers to deliver online purchases).

To reduce complication and optimize available resources, firms segment their international markets into target markets with distinct buying needs; differential benefits sought; and/or unique behaviors. There are six main international segmentation approaches that this chapter discusses: geographic/location; economic factors; political/legal factors; cultural factors; cross-market segmentation; and micro-marketing.

The most logical or obvious segmentation variable seems to be to divide the global marketplace into geographic segments, either by region (e.g., Africa, Western Europe, Australasia, North America, Latin America, etc.) or by country (e.g., China, Canada, Nigeria, Peru, etc.). Although this seems a fairly logical segmentation model, it is somewhat flawed, as the main principle for segmentation is to ensure homogeneous needs (from the consumers' perspective), access, and buying habits. Some value lies in location segmentation. Three factors that are likely to ease trade and exchange in these large regions are (i) the monetary denominations (e.g., Euros in Europe and US\$ in North America), (ii) trade agreements (e.g., the North America Free Trade Agreement and the European Free Trade Association), and (iii) reduced trade barriers (European Union). In many ways though, the assumption 
of homogeny is flawed, as these groupings by location/nation often share minimal common traits or behaviors. For example, business executives in Sydney have little in common with the rural sheep stations in Homerton Victoria, the tour operators on the Barrier Reef, or the iron ore miners on the west coast of Australia. However, regional segmentation is often used as a first, categorical segmentation in order to find a hierarchical structure that will allow for some economies of scale in traveling, distribution, and human resource allocation. For example, Samsung boasts 15 regional offices and 7 design sites, while Coca-Cola reports 5 main operating regions, namely, Asia Pacific, Europe, Middle East and Africa, Latin America, and North America.

Global markets for multinational firms may segment markets on the basis of economic factors. For this approach, income levels or economic well-being and the overall level of economic development of the country and the potential consumers are considered. Segments may, for example, include "developing countries" as a segment, which may be India, Chile, Fiji, Angola, and Argentina [26], whereas the USA, Britain, France, Germany, and Japan (members of the G7) are considered developed or highly industrialized economies.

A slightly less macro-level approach is to consider the local political and legal factors that are likely to influence the willingness to do business with foreign firms, the number of regulations, and bureaucracy. Of serious consideration for the long-term well-being of the firm and its entire supply chain is the political stability of the government. Civil war or the threat of cross-border attacks not only affects consumer confidence but also affects various contracted suppliers up and down the supply chain. Political unrest is likely to impact exchange rates but may even reach [27] as far as impacting the message content and channel firms used to educate and communicate with consumers. A good example of the impact of political unrest or crises on sales is in the area of international tourism [28, 29]. Cultural factors such as language, religion, norms, customs, values, rites, and other behavioral patterns are considered by some marketers to group consumers into segments. A wedding event planner may consider offering a diverse range of events to satisfy her Jewish customers, a segment of Christian brides, and perhaps consumers who have no interest in a religious ceremony but merely wants a family gathering or a party with friends. In contrast proofreaders may decide to segment their prospects (to attract new market segments) as those students who are not first language Englishspeakers but who may be studying at an English-teaching university. For example, the Universities in Australia attract a large number of Chinese students, who may require proofreading services for their postgraduate theses. A Sydney-based proofreading service WriteWell may offer students a valuable service of translation and/or proofreading, specifically focused on ESOL Chinese students studying at Australian universities [30]. The final approach in this discussion of international market segmentation planning (MSP) is cross-market segmentation. In this approach-even if these consumers are situated in different countries-the main criteria marketers used to collect consumers into segments are consumer needs and buying behavior. For example, the eyewear company Ray-Ban positions themselves as "Timeless style, authenticity and freedom of expression are the core values of Ray-Ban, a leader in sun and prescription eyewear for generations" [31]. Ray-Ban is now available in 213 countries, but despite the geographic spread, the main segment the markets by self-image and self-expression groupings, using music festivals and various sport celebrities to influence future buyers [32].

Local marketing (a form of micro-marketing) entails dividing the large global market into concentrated groupings, most likely by cities, by neighborhoods, and in some cases even down to specific stores within a neighborhood. Global brand SPAR (food retail, groceries, fresh produce, and in some cases small delis, pharmacies, fresh 
flower sales units, and jewelry counters) adapts both the width and the depth ${ }^{4}$ of their product offerings to each local area. For example, the SPAR in Morano (previously DeSpar), Italy, sells a huge variety of Italian cheeses and local wines like Prosecco, whereas the SPAR in the small rural town of Moorreesburg, South Africa, sells various spiced biltong (a favorite dried meat snack) flavors and a huge variety of barbeque accessories. A major advantage is an agility and responsiveness of the smaller localized stores (business units of the group) to contextual events and market forces specific to that area. Marketing mixes and marketing communication can be customized to suit the norms, habits, values, and language needs of the local market segment. Specific niche media may be available on a local level that is not available on a national or global scale (e.g., a local newspaper or niche magazine like the North Shore Times may only serve a small sector of a state or region). This local or micro-marketing approach is much closer to the idealized segmentation model of 1:1 marketing but has some important drawbacks for marketers to consider. Foremost, the consistency and reputation of the brand (and its unique value proposition, see later) need to be respected and are often difficult to maintain, given the varied and fragmented markets. Secondly, the widely spread and small nature of the markets pose a big threat to the sought-after economies of scale and add to various sourcing and distribution costs (e.g., delivering highly customized, uniquely adapted products to two different countries, many miles apart). Fortunately, online media and technology has simplified communicating with and targeting highly dispersed (or tightly localized) market segments.

\subsection{Segmenting online markets}

It is quite natural to think that online consumer segments must be the same as other consumer segments. They are simply put as people searching for solutions products and service that can meet their needs and add value to their lives, aren't they? In a way this is true, but since the Internet offers so many alternative sources of product and service information, scholars [33] suggest that a different approach to categorizing online buyers is required. In addition, prospective customer activities, online behavior, and habits differ substantially from traditional retail behavior. Consumers are better informed, are more mobile and traveled, and have more choice due to technological advancements. Forbes [34] reported that social media usage would see the largest growth $(31 \%)$ in marketing expenditure of all available brand communication media. Therefore, marketers use a different set of criteria to categorize online segments, aiming for these customized approaches to deliver more relevant communications and more valued offers. Luckily these technological advancements also enable online marketing, making it is easier than ever to tailor marketing messages to different demographics and consumer categories. Artificial intelligence (AI) and machine learning algorithms (MLA) and tools to analyze big data about consumers with some immediacy (CRM dashboards) make it possible for marketers to now predict website visitors' likes of products and brands based on similar users' behavior [35]. Current models divide online consumers into three basic categories: non-purchaser, purchaser, and potential purchaser segments [36]. In this chapter we will also differentiate between segments by considering information search habits, propensity to shop online, shopping behavior, and site attributes

\footnotetext{
${ }^{4}$ The width of a product range refers to the number of types of products offered, whereas the depth refers to the differentiation within the product range. So, for example, SPAR may offer a small narrow range of shampoos (only three or four brands), but the depth might include a host of types of shampoos from 2-in-1 shampoo-conditioner types to shampoos with color additives and shampoos for babies-all from the same brand.
} 
sought by prospective buyers and current users. Several typologies exist, and new ones are constantly added, due to the fast-changing nature of web developments but also because shoppers get more experienced using the web and online services, and therefore also adapt their habits and behavioral patterns.

Online information technology (the Internet) provides consumers with the ability and tools to share product and brand information online. In 1995, Amazon already offered customers the options to post comments and reviews online [37]. In more recent years, it has become a fairly common phenomenon for companies to seek ratings and after-sales feedback via web-pages-asking only a few seconds from customers to complete firm-generated rating scales or add self-generated review comments [38]. Research evidences indicate that consumer reviews have become important sources of information and guidance for prospective buyers' purchasing decisions and affect brand reputations and product quality perceptions dramatically [37]. But, it is not all good news! Disgruntled consumers are quick to post bad reviews and scathing comments either on the company's website [39-41] or review sites like TripAdvisor, Manta, Angie's List, or Foursquare [40]. Social media offers an outlet for customers to express disappointment, stories about poor service, and claims about unethical actions by firms, arrange boycotts, and spread bad electronic word-of-mouth (eWOM) on various online platforms-all likely to be harmful to the brand. These comments are read, with more than $80 \%$ of prospective buyers indicating that they read reviews to determine the quality of a local business [39]. These reviews and social posts shape a firm's online reputation outside of the planned marketing communications of the firm. Upset consumers go as far as starting anti-brand communities (e.g., Anti-Apple; anti-Wal-Mart [42]) to express their disdain and dissatisfaction with a product or brand or even a social movement to place hurdles in the path of brand growth. User-generated discontent (UGD) and negative ads for products can be easily found on YouTube-some simply making fun of a brand (e.g., Dove [43-45]), others more negative in its comment on the value or acceptability of the brand's practices.

In some cases it is a good marketing strategy to "license third parties" to comment and, in so doing, ensure a sufficient level of review informativeness [37]. Further, proactive marketers create opportunities for consumers and current customers to engage at various levels with the brand and its various products. Marketers consider higher levels of engagement the desired outcome, because customized IMC should result in better engagement, response rates, and thus increased purchase and loyalty levels. The ideal outcome for a firm is to move consumers up the ladder of engagement (in figure $\mathrm{ABC}$ ) to co-create products, thus creating their own demand. Companies use various systems of communication, registration, processing, feedback, and rewards to ensure customer action.

At the first level of engagement, firms merely have a like/dislike button to allow users feedback by clicking the relevant icon. At the next level, online firms like Amazon ask for customer ratings (providing a sliding scale or point system). Customer reviews are fairly common to the travel and hospitality industry, with consumers leaving long or short, often highly detailed reviews of hotels, restaurants, and Airbnb home rentals [46]. Discussions, as the first level of co-creation, are a two-way communication between the brand and its consumers. Home Depot, as example of this fourth level of engagement of discussion and idea-sharing, allows consumers to answer questions regarding DIY projects posed by other consumers, on their website $[47,48]$. At the next level, customers co-create advertisements with the branding team at a firm. In Greece, Kraft Foods published several long-form user-generated advertisements for Lacta chocolate [49]. The sixth level of consumer engagement for online products and brands is co-created brand naming. In 2008, Boeing renamed the 7E7 airplane to Dreamliner, responding to consumers' choice, as 
recorded on newairplain.com by 500,000 consumer-voters [50, 51]. The last, highest level of firm-consumer co-creation is where customers co-create products. At this level, facilitated by social media and other online communication channels (firm websites), customer ideas are sourced (also called crowd-sourcing), and new product modifications or the next generation of product innovations is suggested by consumers and implemented by the firm. Procter \& Gamble uses a forum called InnoCentive, to allow approximately 180,000 freelance students, academics, artists, engineers, and scientists to solve problems that can impact humankind in areas ranging from the environment to medical advancements [52]. Sites like Constant Comedy.com and Dry Bar Comedy [53] on YouTube assist budding comedians to launch their careers using the short-clip user-generated content (UGC) to test and rate users' jokes. Short videos are uploaded to the site and viewers' vote on the performances. Somewhat similarly, but using big data generated by consumers, Netflix analyzes customer selections and binge-watching data to create new series, films, and watch lists for prospective viewers and to recommend films and soap operas to their loyal customers.

Social media consultants [54] of Marsello suggest segmenting online users by actual, measured levels of participation, which is also some indication of their common interests and online surfing and activity habits. When measuring actual engagement and true online media usage, seven segments emerge: segments based on (i) recency, frequency, and money spent (RFM) and customers' engagement into (ii) six sectors, namely, curators (keeping and reposting content), producers (authentic content created by consumers UGC), commentators (consumers' comment on firm content, products, or activities), sharers (consumers sharing advise or experiences), watchers (observing trends and fads and adding to the dispersion or adoption of new products or improvements), and, finally, advocates/detractors (fans and supporters, sharing reviews, links, or eWOM via Facebook, LinkedIn groups, and Google + Circles) [55].

There are several specific approaches to break the entire market into smaller, reasonably homogeneous groups, but e-commerce personalization depends on the data sources marketers can access and personalize against. These segments are decided, based on usage (channel engagement; web search habits, time spent, purchasing behavior) and where trust resides (influencers followed, time habits, likes and dislikes). Figure 5 displays 16 possible segmentation criteria used in e-commerce (Figure 6).

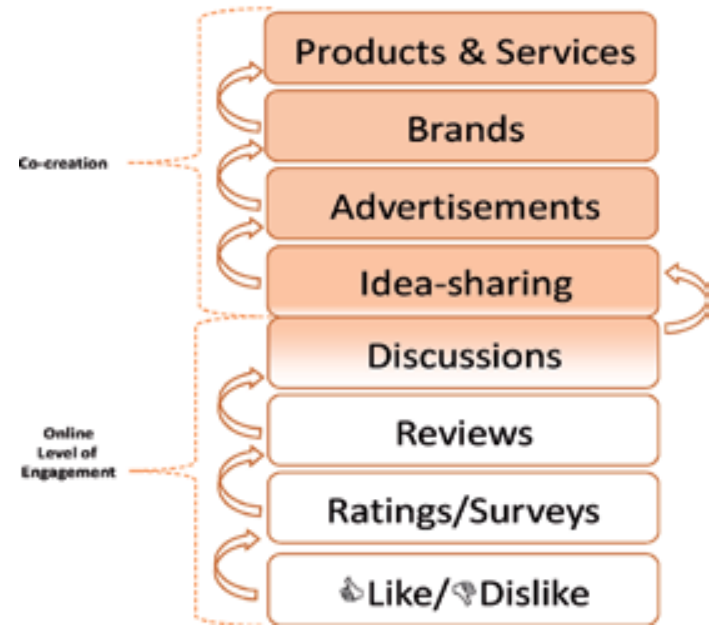

Figure 5.

The ladder of collaborative co-creation for online engagement. 
International Market Segmentation across Consumption and Communication Categories... DOI: http://dx.doi.org/10.5772/intechopen.89988

\begin{tabular}{|c|c|c|c|}
\hline Icons: & Personalization Criteria & Icons & Personalization Criterth \\
\hline & Weacher 8 Season & & Time kabits \\
\hline & Lockeson: Nution $8 \mathrm{Cty}$ & & Lines 5 Disthes \\
\hline & Browsing Habits: Current and past searches & & Aesponse to firm Campaisns \\
\hline & Browsing Habits: Currene and past floeting views & & Aoword Campagens \\
\hline & Rurcharie Sehwiour: Pavment mechods & & Web browsers \\
\hline & Purchane Gehwour: Cat contents & & Search Devike \\
\hline & Age \& Gender & & Metwork, inflivencers 8 , Nliances \\
\hline & Account Trpe (1028 manty): Bricine/Mrodsat fier & & Referrats \\
\hline
\end{tabular}

\begin{tabular}{|c|c|c|}
\hline icon & Personalization Criteria & Description and Impact \\
\hline & Weather \& Season & $\begin{array}{l}\text { Specific products and users may be influenced by environmental } \\
\text { factors such as seasons (fruit, fashion, harvesting equipment) and } \\
\text { the weather (travel, hikine. stiine, divine. etc.) }\end{array}$ \\
\hline & Location: Nation \& Cty & $\begin{array}{l}\text { Marketers can track viser' location when engagine, from country to } \\
\text { city for rural area), dowa to neighbourhood or retail area } \\
\text { frequented. }\end{array}$ \\
\hline & $\begin{array}{l}\text { Visitor Types/Profiles: Carrent and } \\
\text { past purchaves }\end{array}$ & $\begin{array}{l}\text { Profile-based sezments are based on what kind of customer they } \\
\text { are to the business, for eample, Vip, infrequent visitors, first time } \\
\text { visitor. This segmentation allows businesses to upsell, cross sell and } \\
\text { incentivise to buy azain. }\end{array}$ \\
\hline & $\begin{array}{l}\text { Browsing Habits: Current and past } \\
\text { (fleeting/lastingl visitors/searches }\end{array}$ & $\begin{array}{l}\text { New visitors or returning visitors can be identified in analytics. This } \\
\text { is a commonly used technique for personaliastion. E.g. offering new } \\
\text { visitors a discount on first putchase or creating welcoming rewards } \\
\text { for repert purchasers. }\end{array}$ \\
\hline & $\begin{array}{l}\text { Parchase Behaviour: Paymeot } \\
\text { methods }\end{array}$ & $\begin{array}{l}\text { This variable refor to both the total value in the cart and } \\
\text { payment method selected by the online buyer. }\end{array}$ \\
\hline & Purchase Behaviour: Cart contents & $\begin{array}{l}\text { The most common segmentation technique used in eretail is based } \\
\text { on individual products viewed. Related products of a similar style can } \\
\text { be shown, or substituses and value-sdd enhancements can be } \\
\text { offered. Colour, style, quality, materials, them, sizing and other } \\
\text { indicators are valuable to direct future offers or personalize items. }\end{array}$ \\
\hline & Ase \& Gender \& Demographics & $\begin{array}{l}\text { Standard consamer demographics such as age. gender, education, } \\
\text { income, lifestyle, lfe-stage, hobbies and interest are still of value to } \\
\text { marketers of enline prodicts and services. }\end{array}$ \\
\hline & Account Type: Pricing/Product Tier & $\begin{array}{l}\text { This criterium is of ereat importance to } 828 \text { marketers and clients. } \\
\text { Prospects and customers can be segmented based on products and } \\
\text { support services available to themc as well as customited offerings. }\end{array}$ \\
\hline & Time Habits & $\begin{array}{l}\text { Time habits refer to the time spent on a ste, the number of pages } \\
\text { vewed or the time retumed to the page. Consumers' time-based } \\
\text { behavior also vary based on day or week or time of day. }\end{array}$ \\
\hline & Vikes \& Divikes & $\begin{array}{l}\text { What type of response leves can we expect from this group, to our } \\
\text { firm-generate "push" advertisements? Which type of offers. } \\
\text { mesuges, contem and campaien design works best for this group? }\end{array}$ \\
\hline & Response to Firm Campaigns & $\begin{array}{l}\text { What type of retponse level can we cupect from this group, to our } \\
\text { firm-geterate "push" advertisements? Which type of oflers. } \\
\text { messages, content and campaign design worls best for this group? }\end{array}$ \\
\hline & AdWord Campaizes & $\begin{array}{l}\text { Can we use specific add words that are more likely to land cur mast } \\
\text { sought after prospects on our website? }\end{array}$ \\
\hline & Web-browsers & $\begin{array}{l}\text { Which caline search engine is most lialy to provide searching } \\
\text { prospects with access to our firm's web site and other online } \\
\text { information sources? }\end{array}$ \\
\hline & Search Device & $\begin{array}{l}\text { Which search devise do these users most often use to access our } \\
\text { firm's information: table or large screen format, smart phones, etc? } \\
\text { A is able to identify multi-devise tracking including Apps usage. }\end{array}$ \\
\hline & Networks, Influencers \& Alliances & $\begin{array}{l}\text { Who are the most likely influencers to engage, education and } \\
\text { persuade this group of online users? Are these influencers alliances } \\
\text { (other web-sites and collaborators, or other consumers? }\end{array}$ \\
\hline & Referrals: & $\begin{array}{l}\text { Which site did your visitoc come from, prioc to landing on your } \\
\text { website? What can we learn about offers that work best for } \\
\text { visitors from referrat sites, social media, or from pald link ads. }\end{array}$ \\
\hline
\end{tabular}

Figure 6.

16 online segmentation/personalization criteria (adapted from smart insights [55]). 


\begin{tabular}{|c|c|}
\hline $\begin{array}{l}\text { Typology/ } \\
\text { Classifications }\end{array}$ & Description \\
\hline The Simplifiers & $\begin{array}{l}\text { These online users spend only } \pm 7 \text { h p.w. online, but } \\
\text { accounts for }>50 \% \text { of all online-transactions. }\end{array}$ \\
\hline The Surfers & $\begin{array}{l}\text { These consumers spend approximately } 32 \% \text { of their time } \\
\text { online and visit } \pm 4 \mathrm{X} \text { more sites than other users. }\end{array}$ \\
\hline The Connectors & $\begin{array}{l}\text { These consumers normally prefer "brick-and-mortar" } \\
\text { retail, and is fairly new to the internet. }\end{array}$ \\
\hline The Bargain Hunters & $\begin{array}{l}\text { These are consumers who like to find bargains and enjoy } \\
\text { finding "deals". }\end{array}$ \\
\hline $\begin{array}{l}\text { The Routine } \\
\text { Followers }\end{array}$ & $\begin{array}{l}\text { Online addicts who seek mainly information but use the } \\
\text { net to access the information sought. }\end{array}$ \\
\hline The Sportsters & Sport Enthusiasts and Entertainment seekers. \\
\hline
\end{tabular}

Figure 7 .

Media matrix of McKinsey (2000) online shopper typology.

\begin{tabular}{|l|l|l|}
\hline \multicolumn{1}{|c|}{6 Clusters } & \multicolumn{1}{c}{ Description } \\
\hline Brand Comparison & $\begin{array}{l}\text { These shoppers compare product features, prices and } \\
\text { brands before shopping, actively seeking promotional } \\
\text { offers. (More likely in the age-group 25-29) }\end{array}$ \\
\hline Dual-Shopper & $\begin{array}{l}\text { Dual shoppers are more likely to be single male and in the } \\
\text { age group 15-24. They rely on the Internet for information, } \\
\text { but are not deal prone. }\end{array}$ \\
\hline $\begin{array}{l}\text { Traditional Offline } \\
\text { Shoppers }\end{array}$ & $\begin{array}{l}\text { These are mostly in the age bracket } 40-49 \text { and do not look } \\
\text { for bargains or comparative information on the Internet. } \\
\text { They prefer buying from brick-and-mortar stores. }\end{array}$ \\
\hline On-Off Shopper & $\begin{array}{l}\text { These are consumers who like to surf the Internet for } \\
\text { information, but prefer to shop offline. They use } \\
\text { bookmarks and the same search engine regularly. This } \\
\text { group is most likely between } 15 \text { and } 24 \text { a. and of both }\end{array}$ \\
\hline genders. \\
\hline $\begin{array}{l}\text { Information } \\
\text { Surfer/Ad } \\
\text { Orientation }\end{array}$ & $\begin{array}{l}\text { The info surfer is more likely to be married, loves banner } \\
\text { adverts and click thru on them. They look out for } \\
\text { promotional offers. They are expert navigators and has } \\
\text { extensive online purchasing experience. }\end{array}$ \\
\hline E-Laggard & $\begin{array}{l}\text { E-Laggards are likely to be female (>37 a.). He/she has a } \\
\text { low interest in finding information online. After the } \\
\text { traditional shoppers, they are the group with the lowest } \\
\text { Internet navigation expertise }\end{array}$ \\
\hline
\end{tabular}

Figure 8.

Kau-Tang-Ghose (KTG) clusters of online surfers and shoppers.

Marketers have the ability to share information with a vast range of audiences and potential customers, using blogs, photographs (Instagram, Flickr, and Pinterest), videos (YouTube, own site, directed communication), personalized direct e-mail campaigns, and corporate website content. Social media widens the range and reach of firms' communication mixes and a range of channels and formats. Various goals can be addressed in various ways (but consistency in value, look-and-feel; thus 


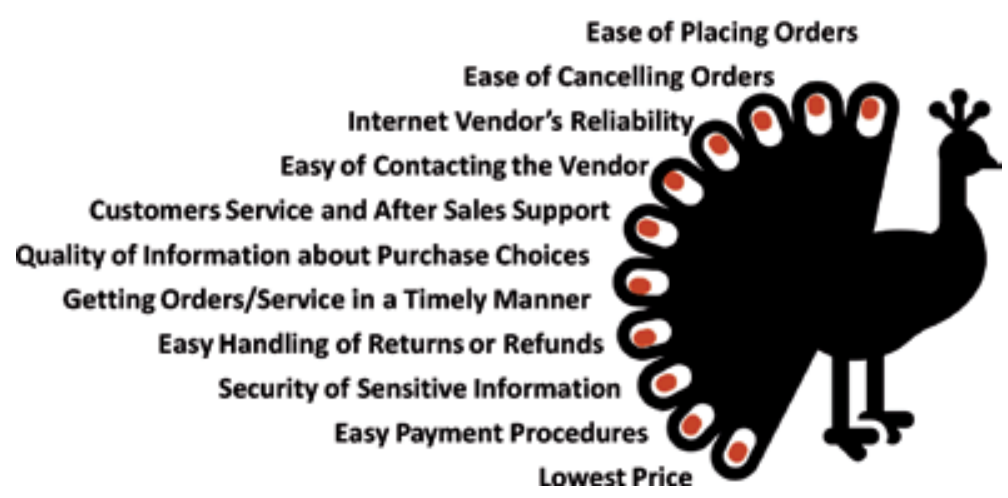

Figure 9.

Fantail of attributes sought by e-shoppers (adapted from [60]).

IMC is essential to build recall, recognition, and brand reputation). For example, Pinterest can be used to inform and excite (gain interest), whereas YouTube can be used to entertain, educate, or add multimedia (sight, sound, subtitles, etc.). A highly valued feature of social media is the ability to bookmark sites [56].

Bookmarking facilities on social sites allow visitors to post the firms' messages to their own Facebook pages, link them to their LinkedIn profiles, or share links with their own networks of colleagues, associates, and friends. This e-word of mouth (eWOM or word-of-mouth) is very valuable to marketers, as these shared links add credibility and trust to the message and widen the reach and impact of the firm's marketing communication [56]. Twitter, with its 140-character limit, is hugely popular to the blogging online community, with 336 million (66 m in USA and $40 \mathrm{~m}$ in Japan) monthly active users (MAU) and 500 million tweets per day. Firms listen to the Twitter chatter about brands to see which key phrases are associated with their brand and product offerings. According to Reuters Press [57], Dell computer company, Twitter played an important role in selling millions of dollars' worth of online products (Figure 7).

Departing from the original study by McKinsey (2000) reported by Hamilton [58], Kau et al. [59] studied 3172 shoppers to review and expand the typology developed by McKinsey, to link demographics to behavior indicators and find a more sophisticated matrix to combine on- and offline shopping behavior. This is important for marketers, as demographics are normally easy to source and identify for targeted communications and segmented marketing mixes, whereas behavioral characteristics are more difficult to investigate [59] (Figure 8).

The KTG typology is useful to marketers, since each group has different demographic and psychographic characteristics. The clusters also display different (homogeneous within clusters, but different between clusters) online and offline purchasing behavior. A SMP based on these segments will assist marketers in devising promotional and communication plans to suit specific segments of shoppers. Marketers can build on the fundamentals of direct, personalized marketing applied offline and combine it with the capabilities of machine learning to deliver the nearest thing to 1:1 marketing. According to KTG [59], "the access to information, the ability to easily compare, the convenience of not having to go down to the mall and the use of familiar brands-drive e-commerce" (p. 156). E-Shoppers value various online service aspects, ranging from the quality of information, the ease of placing orders and returning goods, to pricing, security of personal information, and vendor's reliability in getting the order to the buyer in a timely manner (Figure 6 for the full range of 11 sought-after attributes) [60] (Figure 9). 


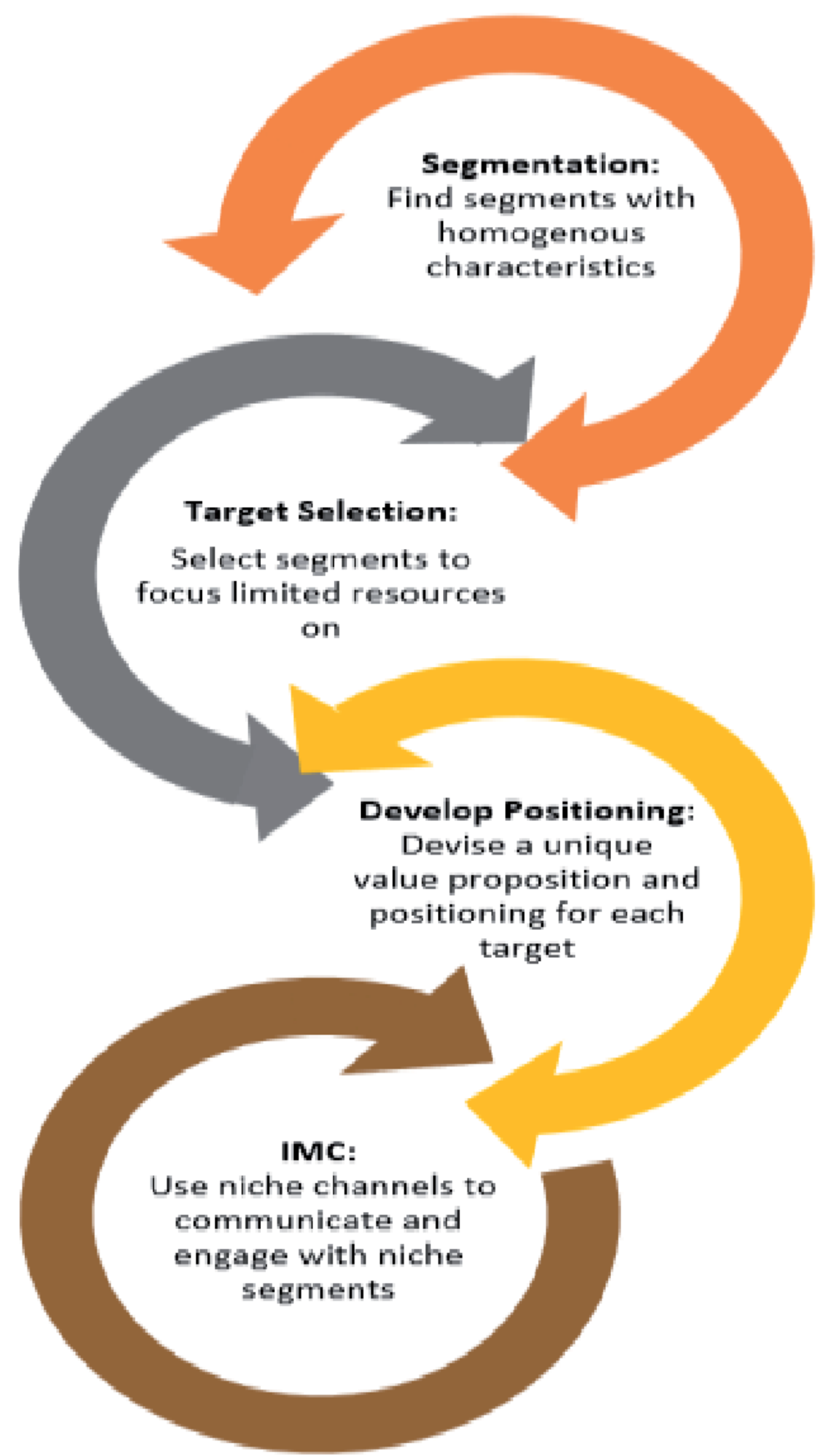

Figure 10.

The relationship between segmenting, targeting, positioning, and niche marketing (adapted from [3]). 
Selecting the right cluster of online shoppers (segments) for the firm's offers is thus of great importance, not only to determine the clusters' unique communication needs but also to understand what motivates particular clusters of Internet users and focus the firm's efforts on those attributes most valued by the firm's target audience(s).

\section{Targeting specific segments}

Whichever approach marketers use to segment the market (or choose to eliminate suspects to find possible prospects to qualify, inform, and ultimately engage), viability, and usefulness needs to be determined. The two most important strategic marketing decisions a business will make are choosing the most rewarding market segments and determining how to position its offers. Selecting rewarding (in terms of various objectives including maximizing profitability, maximizing market share, entering a new strategic market, building brand reputation, etc.) segmentation is the first of a three-step strategic process. The next stages are selecting the targets for the firm's marketing efforts; positioning the firm's offer or brand in the most attractive way to attract and engage the preferred segments; and, finally, allocating marketing resources to pursue prospective groups of customers [61]. In the past, scholars suggested these stages are consecutive, linear stages, but today scholars concur that segmentation is an ongoing, iterative process that needs to be regularly (even continuously) re-examined and reconsidered. Business market segments are highly dynamic due to the quick response of marketplace competitors to demands from customers, new technological and other radical innovations, as well as economic up-and-down turns. Sophisticated marketers will even attempt to anticipate and predict contextual instabilities to prevent having to play "catch-up" to more astute competitors $[62,63]$. It is marketing, sales, and new business managers' responsibility to continually reassess the original bases for current segments and to remain vigilant about the personal, situational, and contextual factors that might impact their current and future customers (Figure 10).

\subsection{Targeting to optimize market share and profitability}

Most organizations have moved away from mass (undifferentiated) marketing to targeted (differentiated/segmented) marketing: identifying and dividing the likely buyers into somewhat homogeneous segments to serve and then selecting a few to focus the firm's limited resources on. Even the wealthiest firms cannot afford to serve all customers and prospects equally. For the undifferentiated marketing strategy, marketers focus on common needs, shared by consumers in the mass market, rather than the differentiated needs, shared by similar consumers. The communication strategy is aimed at messages that appeal to as large aroup as possible. Communication and marketing tactics are directed at the whole market rather than a particular niche audience. This strategy is not one most marketers would pursue, despite the economies of scale due to lower production and distribution costs, because, despite minimal cost spent on research and niche messages for niche audiences, most marketers fear that discerning customers who are spoilt for choice may not respond well to generalized marketing messages. Marketers fear that less satisfaction is likely when offers are not customized. A concern with a large number of direct and indirect competitors in such an undiversified marketplace results in firms focusing efforts on a select few, well-differentiated market offerings. General Motors offered "a car for every purse and purpose." A buyer might start with a Chevrolet and gradually trade up to a more exclusive Buick or Cadillac [64]. Today 
Toyota tries to emulate this strategy with a car for every purpose and personality, with the Rav4 aimed at the more outdoorsy, adventurous types, the Camry for the more conservative, money-conscious family buyers, and the Toyota Lexus for the elite luxury seekers. The third type of targeting strategy is a concentrated marketing strategy. This is always called niche marketing or a niche market strategy. When firms have very limited resources, a niche strategy is one where a firm focuses on gaining a large market share of a small sub-segment (as opposed to a small share of a large market segment). The main benefit of niche market segmentation is that the firm is likely to have fewer direct competitors in the chosen niche segment. With the niche media and direct channels offered by social media and the World Wide Web, it is today easier than ever to focus efforts and resources on a small niche group. For example, on TradeMe, consumers can buy and sell good-as-new used goods to private buyers. Small online traders can focus on a high niche sub-segment. For example, small galleries may focus on handcrafted pottery or sell their uniquely crafted, handmade items via Etsy. Etsy was launched in 2005 in Brooklyn, USA. Today Etsy has more than 60 million items and more than 40 million users-connecting 2.1 million sellers with 39.4 million buyers for a gross merchandise sales (GMS) of approximately \$US 4 billion $[65,64]$.

"For a differentiated MSP, the firm targets a selection of market segments, and designs separate uniquely differentiated offers for each target audience".

There are four main steps to market targeting:

1. Dividing the market into buyers who might have different needs, requiring separate marketing (product, price, promotions, distributions) and communication (channels, niche media, targeted messages, content, and stories) mixes, which we have discussed above.

2. Selecting a segment (two or three) to target, which is attractive and viable.

3. After that the firm designs a unique value proposition (UVP or USP = unique sales proposition) to differentiate itself from competitor offerings.

4. The final step in the MSP is to integrate all communication and promotional efforts to offer a clear, distinctive, and desirable place in the mind of its potential target audience(s).

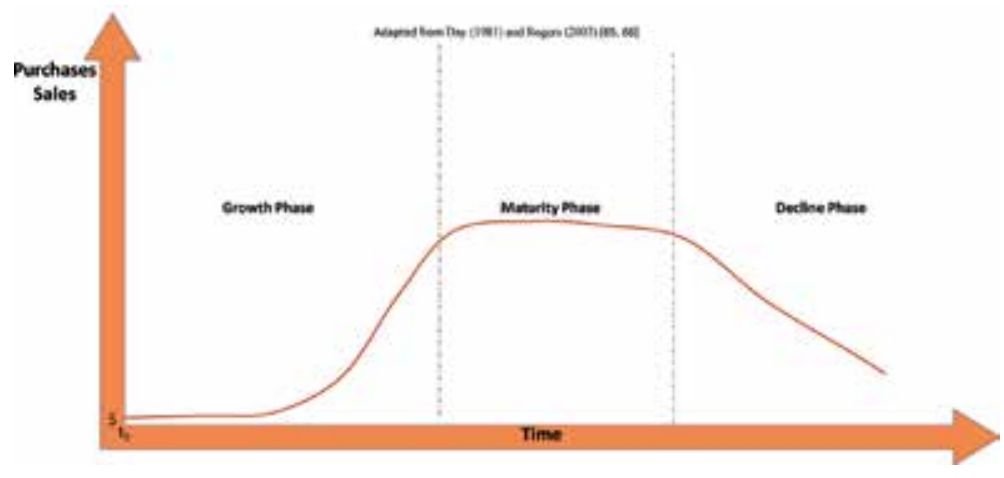

Figure 11.

The product life cycle (PLC) in three stages (adapted from [66, 67]). 
Selecting the firm's targeting strategy is based on a series of five important factors. First, the firm's resources (or lack thereof) are likely to play an important role in this decision. With limited resources, highly concentrated or niche segments are likely to be the more viable market-targeting strategy. Second, the particular product and the firm's ability to differentiate the product/service offering will also impact the segmentation strategy (Figure 11). Third, the product life cycle (PLC) stage needs to be considered during the decision-making process (Figure 5).

A sound choice will concentrate efforts for new products, launching one or two versions of the product initially or perhaps launching only one product type to an undifferentiated market. When the product achieves higher levels of awareness, adoption, and growth, the firm might select a more differentiated targeting strategy. In the next section, this chapter considers the tests for effective segmentation.

\subsection{Implementing MSP: tests for effective segmentation}

Developing market segments and assessing their viability rely on detailed analysis of marketing research, sales data, customer and buyer information, and contextual and competitive information. Some firms though focus on segmentation purely by product type or product size (e.g., this would be similar to Coca-Cola deciding to segment the market by those who purchase $330 \mathrm{ml}$ cans and those who purchase $2 \mathrm{~L}$ bottles). In contrast another segmentation error is seeing the entire industry as one segment. For example, a firm making sails for boats might see themselves as selling "sailboat sails," missing out on a whole section of potential customers like umbrellas, tents, or other outdoor equipment and protection. This is termed marketing macropia [68]. An overly broad view of an industry could be linked closely to firms' inability to identify a range of core needs for which the firm's offers are solutions. For example, a service like hair dressing does not merely sell "haircuts" or serve only to solve untidiness or unruly hair problems. Hair styling artists of Se Salon may serve customers' need to look more fashionable (contemporary styling), or look a bit younger (ageappropriate but modern styling), or fit in with regulations (police and service people styles) or merely to be pampered (an hour away from obligations and responsibilities while being pampered-including a scalp massage). Seeing themselves as "personal grooming professionals," Se Salon might even extend their market segments to include beard grooming, shaving, eyebrow shaping, and other related services.
"Marketing myopia is an approach to marketing that fails to define the firm's products in terms of the customers' needs and wants. It results in the failure to see and adjust to the rapid changes in their markets" [69].

It is therefore important for marketers to assess (and reassess as we will discuss later) the effectiveness of their segmentation analysis and answer the question: "Which market segment will we serve?" By considering all likely segments and selecting viable segments based on five main criteria that are substantial (large enough to make the firms' efforts and investment of resources worthwhile as they relate to our marketing objectives); differentiable (can the firm create offers and a marketing mix that is of value to the segment, and the segments are homogeneous within and heterogeneous between segments); measurable (reliable information about the segments need to be obtained via primary or secondary sources); accessible (are there available and uniquely targeted channels to reach them), and fairly stable (the market must not decline, reduce or fluctuate unpredictably). The segment size and growth (or not) are a relative issue. Firms would obviously prefer segments that are large in current sales and likely to produce high volume and size in future transactions, with a high profit margin. Unfortunately, some fast-growing 
segments might not always be the most attractive ones, as they may be high in restructuring or re-engineering costs. The firm might not have the right equipment and/or talent to serve the target market. It might be in the interest of the firm to select segments that are smaller at the outset and somewhat less attractive for current transaction size but are potentially more profitable.

"Segments can be labeled as "large" based on current transaction size, potential purchases, or even their ability to generate leads for the firms' clients—with their own clients as referees and referrers".

A good example is HSBC Bank who might offer savings accounts and fee-less ATM cards for young teenagers, in the hope to retain their business well into their high earning years, where profit will be gained from these future employees' salary income, credit cards, house bonds, education policies, insurance, and other interest-bearing and fee-bearing transactions. Some segments might even be chosen purely on their ability to refer business, so the indirect income from reciprocal business is important to the firm. An example to illustrate this principle is a lawyer Smith \& Samson, who might do legal work for an estate agent, says Pam Golding, not because the estate agent industry is particularly lucrative or a key account but because the estate agents at Pam Golding have large housing developers, landlords, and homeowners as clients, whom they can refer to the lawyer in a mutually beneficial, noncompetitive lead generation networking relationship. They might share clients without competing for business in any way or form.

Firms need to be attentive to the number of segments they choose to focus their limited resources on-both selecting too many or too few segments can cause problems in the long run [70]. Too many might not make the firm's scarce resources stretch far and wide enough to tailor differentiable value to the specific needs of

\begin{tabular}{ll}
\hline Segmentation selection criteria & Concepts and considerations \\
\hline Firm strategy & Corporate vision and direction \\
& Brand positioning and reputation \\
& Management commitments \\
& Organizational requirements \\
& Marketing objectives \\
& Competitive positioning \\
\hline Resource demands & Technology \\
& Relationships \\
& Human resources, purchasing of resources \\
& Services and sales \\
& Production \\
& Image \\
& Capital investment required \\
& New product development (R\&D) \\
& Size and growth \\
& Profitability \\
Future attractiveness & Relative risk \\
& Competition \\
& Government considerations \\
& Contextual considerations \\
& Technological demands (of the firm, from clients) \\
Current relationships \\
Development of new relationships \\
\hline
\end{tabular}

Table 2.

Segmentation selection criteria (adapted from [71]). 
consumers; and too few segments might lead to a marketing plan that fails due to the demise of certain segments, as the context shifts.

Once the market is divided into a select few, likely segments (seen from the perspective of the marketer), marketers need to evaluate the segments' attractiveness by asking four basic questions: Is the market large, growing and likely to be profitable enough to pursue (MONEY)? Would the marketing communications and our marketing mix allow us to access these prospective customers, OR would we be able to reach this segment via particular, customized, or well-targeted media (MARKETING ACCESS for ACQUISITION)? Does targeting this segment fit in with the vision, mission, and strategies of our firm (CONCENTRATED) and the capabilities the firm has, or is it able to acquire within a fairly concentrated time (CAPABILITIES)? Used as an acronym, these four questions spell out MACC. Marketing experts Freytag and Clarke [71] suggest evaluating potential segments by considering three strategic imperatives: (i) firm strategy; (ii) resource demands; and (iii) future attractiveness. Table 2 illustrates the construct and the building blocks of each off these selection criteria. In some cases, the firm will develop its own new market segments to align with the need they wish to fill. For example, Swatch watch producers educated consumers that a watch can be more than a time-keeper and an inheritance-it can be a statement of style, fashion, and personality - thus creating a new category with new demands and thus an entirely new segment of watch wearers. The Sony Walkman portable audio player, launched in 1979, was the first truly "totally portable" stereo cassette recorded music player [72]. It was much smaller than an 8-track player of the earlier cassette recorder/players, was listened to with stereophonic headphones (unlike previous equipment which used small loudspeakers), and was small enough to be carried around. Sony educated consumers that they can compile their own music playlists (no need to buy the full record/cassette) and that buyers could take their playlist wherever they went. Today's music lovers can download the Sony Walkman Music Player Android App APK for high-definition music player only for Android smartphones and listen to "your own playlist of....stylish, sizzling music" [73].

Once a firm has considered the viability, they need to focus efforts on a few segments they wish to serve. This set of prospects, buyers, and customers with a set of homogeneous characteristics is called a target market. When firms select highly similar segments and focus on the commonalities of all segments, they are essentially undifferentiating the marketing mix. This is only a viable strategy if the competition is limited. For a differentiated marketing strategy, marketers design specific marketing communication and marketing mixes for each target segment. When represented as a web of activities, Figure 8 depicts how a variety of tools and investments at various levels could be used to best satisfy the unique needs of different segments. For Target 1 consumers, a large number of product offerings (willingness to personalize products, e.g., luxury robots) are available, while the firm offers a very low range of unsophisticated products to Target 2 customers (this might be the very basic products with no frills). So, for Target 2 customers, the price band is narrow (small variances in price). The budget to promote the product is also low. These "basic" products could be sold in a variety of outlets, including online sites, while the luxury, highly customized products for Target 1 are sold only in exclusive boutique stores. The physical evidence (such a packaging, branded material, and point-of-sale items) and people (sales professionals and customer care officers) for Target 2 may be more varied, due to a large number of outlets involved in the sales process. Partners such as franchisees and the various site owners will be numerous for the marketing strategy to reach and distribute to Target 2 consumers (Figure 12). 


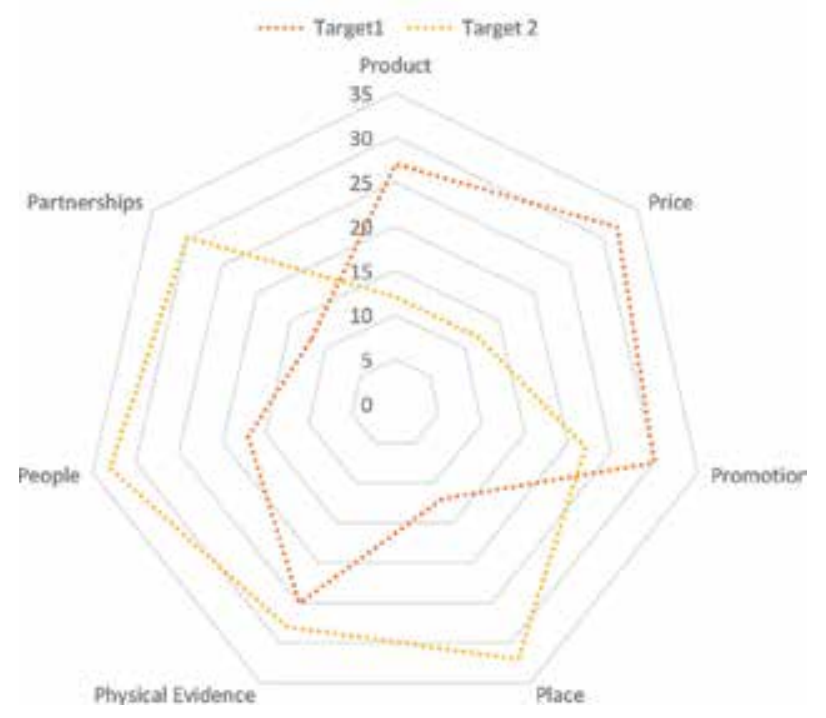

Figure 12.

The marketing mix for two unique target markets.

To facilitate the integration of all communication from the firm with the selected target markets (IMC), all segments need to firstly be aligned with and secondly keep in pace with changes in firm strategy, culture, tactics, structure, capabilities, and resources [74]. Authors Dibb and Simkin [74] suggest that internal (to the firm) audiences need to be identified who play key roles in communicating and liaising with customers, to allow them to make changes to marketing plans and communication programs to stay congruent with the MSP. To implement the selected or revised segmentation plan, managers will need to be given specific responsibilities and resource (time, money, staff, equipment) to roll our solutions to these segments. Finally, various business units will need to develop methods to monitor and control the effective implementation of the SMP.

\subsection{Targeting and positioning for sustainable competitive advantage}

Once upon a time, filling stations sold petrol and supermarkets sold food and groceries. Today, filing stations sell a wide range of products from oil, diesel, and petrol to automated car washes, fresh coffee, pastries, groceries, and a wide range of snacks. Grocery stores sell everything from fresh produce to kitchen utensils, clothing, pharmaceuticals, magazines to garden furniture, flowers, and DIY tools. Some category-less firms take a large share of wallet (\% of consumers' discretionary budgets), offering a wide range of products, services, and solutions. For example, Walmart and Tesco brands can probably sell customers anything, including legal advice and wedding planning. In New Zealand, grocery giant Foodstuff's grocery stores, New World, sell everything from bread and milk to socks, medicine, glassware, gardening equipment, and electric blankets.

Adept marketers understand the power of the brand and the role of "positioning" in accessing their larger-than-fair share of wallet. It is critical in this hypercompetitive, borderless marketplace to understand how to attain and retain a sustainable competitive advantage. Marketers use a variety of positioning activities to develop a meaningful distinction from competitors in the mind of current and future customers [7]. Several possible sources of SCA can be found in the eight Ps 
of the marketing mix: product differentiation, competitive pricing (based on cost efficiencies), distribution channels (including online and global logistics), promotions and special offers, and innovation (including R\&D, patents, and intellectual property) [75]. A key selection criterion to determine possible sources of differentiation is that the selected target markets of the firm must see these attributes, characteristics, and variables as valuable, as discussed in the next section.

\subsection{Positioning, unique value propositions and perceptual maps}

Once a firm has selected the (few) target markets to focus its limited resources on, it must determine a differentiation and positioning strategy. There are four distinct (but iterative) steps in this process:

Step 1: Identify a set of possible differentiators that are likely to create a sustainable competitive advantage.

Step 2: Choose advantages that are valuable to the firm and to the target audience(s) and on which the firm hopes to build a position (in the minds of those prospective consumers.

Step 3: Select and design an overall positioning strategy.

Step 4: Design and implement integrated marketing and communication tactics to support the overall positioning strategy. It is imperative to sustained success that marketers review these four steps and decisions related to those steps regularly (as they review target segments as well) and renew and refresh ideas and strategies regarding their SCA and the tactics to create and maintain distinctive benefits and distinguishable advantages (Figure 13).

A brand's full positioning is defined [61] as developing a theme that will produce a meaningful distinction for customers. According to Kotler [3], a product's positioning is the complex set of perceptions, impression, and feelings that consumers hold for the product compared to its competitors' products (goods and services). Therefore, brand positions are essentially a place made in the mind of consumers, whereas products are made in factories [7]. Firms can decide on the feature and include benefits in the products and services to ensure a particular set of attributes is associated with the product. In this way, firms can ensure that their product-service offering occupies a specific (predetermined) place in the mind of potential and existing customers. For example, Volvo is positioned as safe care, due to the manufacturer's emphasis on safety through technological advancements [76], whereas $B M W$ owns the brand position space of quality and excellence in the driving experience, due to its constantly reinforced brand message of "sheer driving pleasure" and more recently "ultimate driving machine" [77] and "designed for driving pleasure" [6]. In fact, it seems the slogan "Vorsprung Durch Technik" has transformed the entire positioning of the national brand of German products, and in particular family cars, to a position of quality, efficiency, progress, and technological innovations [78]. Marketers cannot leave their positioning to chance or to the consumer to decide-because consumer will position products and brand with or without the intervention of marketers. But, to get the greatest competitive advantage, marketers have to design and actively pursue planned positions.

To identify perception gaps or to identify positioning opportunities in the marketplace, marketers use perceptual maps. A perceptual map can be used to display comparative brands' positions-as they relate to benefits sought by particular target audiences. Marketers use several perceptual maps contrasting a variety of key attributes (as sought by consumers and prospective buyers) to plan differentiation and positioning strategies and tactics. To allow for easy interpretation, and to clearly identify opportunities and threats, only two attributes are displayed at any one 
time, creating four quadrants. Figure 10 portrays such a comparative analysis of Australia/Pacific Airlines. On this particular perceptual map, the desirable positions are fairly close to the central point, OR the entire quadrant $A$, the top right hand corner of quadrant B (where the airline still has an acceptable status), or, if achievable, quadrant D. Airlines are unlikely to occupy quadrant C (high quality and low status) - unless they are not achieving well on another key attribute (say departing and landing on time). Airlines occupying quadrant D have high status and low quality of service. This is unlikely as most customers demand high quality of service despite paying less, and the airline will therefore have to achieve extremely high levels of satisfaction on other key attributes not portrayed on this particular comparison of attributes (say personalized onboarding, shorter waiting times, better luggage allowances, and other highly rated product and service attributes).

The orange dots on the perceptual map of airlines in Australia and New Zealand (Figure 10) indicate that Qantas and Air New Zealand are perceived as offering high-quality service and in-flight food and have achieved a high level of status in the minds of consumers in that region [79]. The red dots in the top right corner, adding Emirates and Cathay Pacific Airlines, indicate that a study among international students at a university in New Zealand added two airlines that are not normally seen as Australia/Pacific airlines, to the perceptual map. This study indicates that "real-world" surveys of target segments of consumers bring their unique perceptions of their own rankings into a brand's perceptual map. Probing questions indicate that students often fly from New Zealand to their home countries (China, Japan, Saudi Arabia) using Emirates and Cathay Pacific and these airlines are ranked higher in status and quality of service than the best Australia/Pacific airline brands.

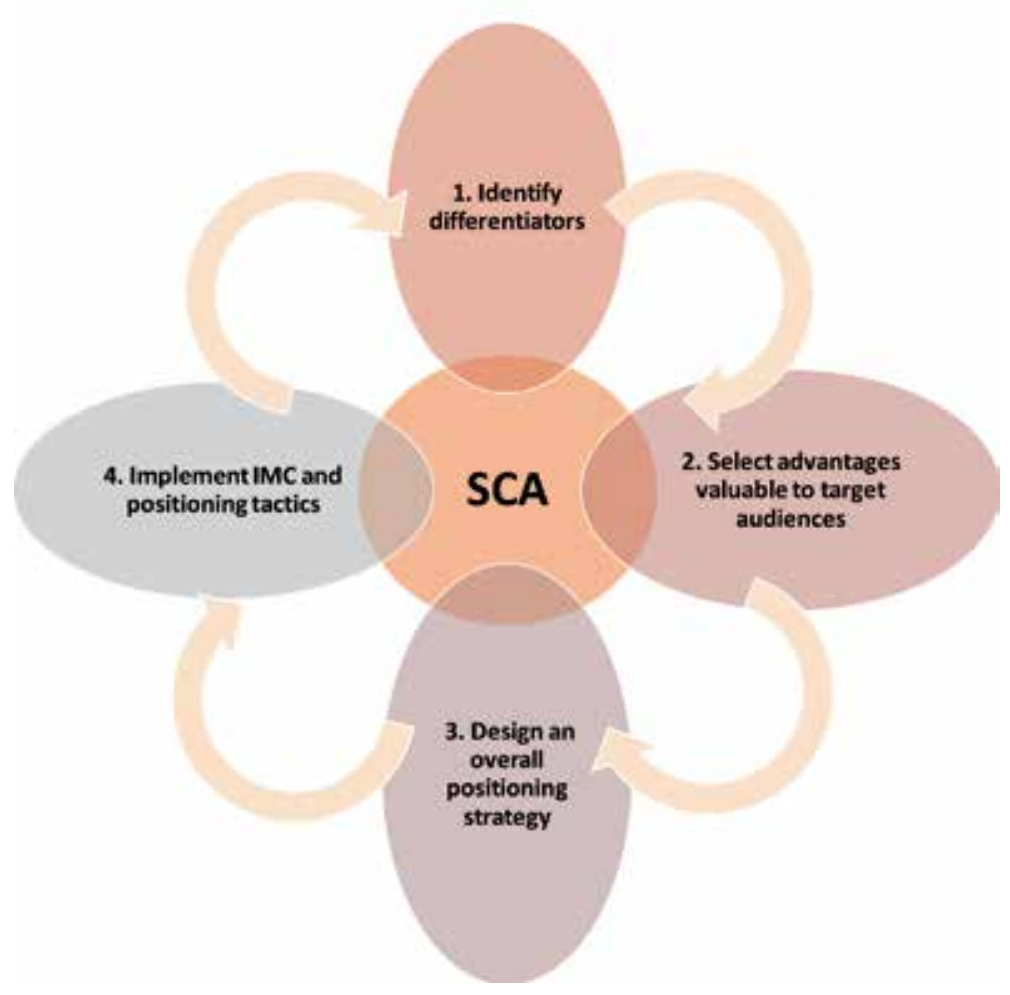

Figure 13.

Four iterative stages in creating a positioning strategy. 
Marketers should take from this that it is really important to survey real consumers and current customers to see what the true current reality looks like (Figure 14).

The cluster in quadrant $B$ indicates that there is very little differentiation in either food quality or status of the six airlines competing in this space. Although Jetstar is perceived as of higher status, consumers' perception of its service and food quality is barely different from Fiji Air. So, should Fiji Air decide to improve their service and food quality substantially, they may become a threat to Jetstar's position in the marketplace-if all other attributes stay equal [79].

Students of marketing communications and SMP might ask: How many differences should a brand promote to attract a specific market segment or segments? Is it not confusing when a brand promotes several differences for the same productservice combination? For example, a shampoo by Schwarzkopf offers benefits such as treatment for dandruff, softening hair, adding gloss and shine, reducing breakages, and maintaining highlights or artificial color [80]. Clearly some customers would want all these benefits. The challenge though is for the brand to decide how to deliver on all four product benefits, without confusing the brand positioning. Should the brand consider just promoting one or two or three of these benefits? Should Schwarzkopf focus on one benefit per target audience, for example, just concentrate on adding gloss to highlighted hair, thus focusing on consumers who have their hair colored regularly. Or should the brand only focus on one offering towards consumers with dandruff problems and another on consumers with color-treated hair? Should these feature as separate benefits offered to separate target audiences? Should all the be combined and risk loss of clear positioning, but gain a wider appeal to diverse target audiences?

A brand's value proposition is a clear statement that explains what benefits the brand provides for who and how the brand does it uniquely well. It describes the target buyer, the pain points it offers solutions for, and why the brand is better than any competitive substitutes or alternative solutions [81].

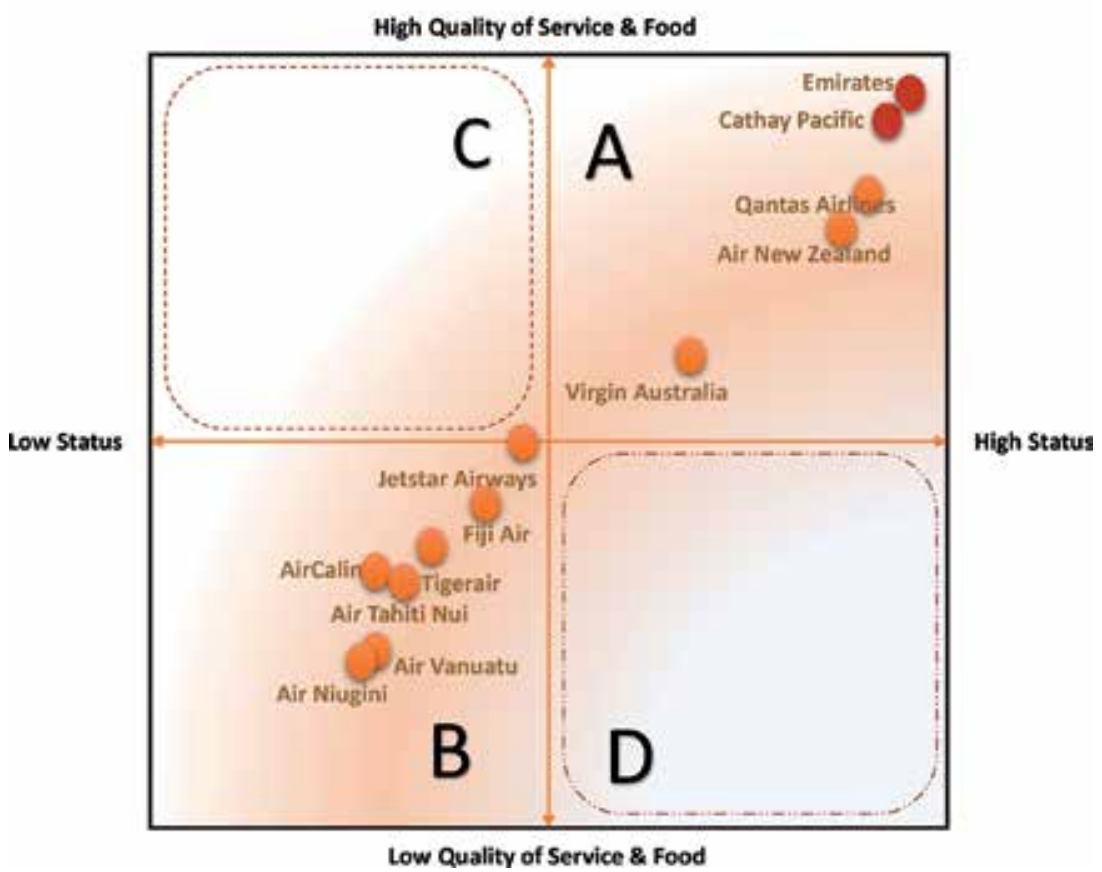

Figure 14 .

Perceptual map of Australia/Pacific airlines 2018 (source: world airline awards [79]). 


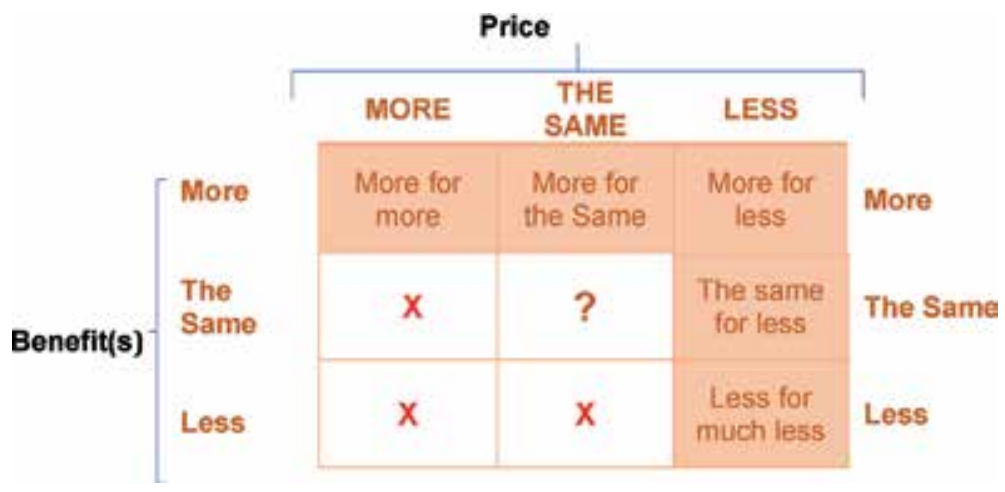

Figure 15.

Various winning and losing differentiating strategies.

"The full mix of benefits a brand offers to a range of segments is called the brand's value proposition".

Some examples of carefully crafted, single-sentence statements by brands are Lyft, "Rides in Minutes"; Budweiser beer, "The Great American Lager"; and Walmart, "Save Money. Live better." According to scholars, there are only five combinations of benefits and price combinations which are "winning value propositions," namely, offering more value (benefits to the customer) for a lower price (more for less strategy) or offering more value for a higher price (more for more = luxury and top-tier products at a higher price tag, e.g., Louis Vuitton Bags) or more value for the same price (more for same = comparable product quality but at a lower price, e.g., Lexus versus Mercedes) or the same value but for a lower price (same for less = or lower-tier brand such as Maybelline as a L'Oréal) or fewer benefits for a much lower price (less for much less = discount store or every-day-low-price stores such Pak'nSave, Checkers Warehouse stores, or Formula1 Hotels). Other alternatives on the price/benefit matrix are losing value propositions [82, 83]. (See Figure 3 for the winning value propositions highlighted in orange. Losing propositions are marked with a red $\mathrm{X}$ ) (Figure 15).

\subsection{Implementing MSP: monitors and controls of segments}

According to Consulting Group Symmetrics [84], a market segmentation strategy should answer five key questions:

1. What markets do we pursue?

2. Which customers do we target?

3. Which marketing and sales channels fit with how our customers buy?

4. How do our offerings fit with our markets and channels?

5. What is our unique value proposition to each target customer?

From this chapter, it is clear there are many market segments a particular firm can profitably pursue. So, marketers have to carefully define which offerings and 
messages most likely to resonate with their target markets and differentiate the firm from the competition. So, conducting highly focused competitor analyses regularly is a STP imperative. These competitor analyses are aimed at finding ways to counter or improve what does or does not work, to guide business decisions regarding redefining, contracting, or expanding target markets. Marketing managers (including sales, PR, sponsorship, advertising, management) need to monitor if the STP plans work continually. Firms need to measure, monitor, and track your key performance metrics via weekly, monthly, and quarterly reports (also called dashboards of big data) to ensure mid-course adjustments to strategies, tactics, and the use of marketing and sales resources. Consultants Tracey and Wiersema $[85,86]$ suggest that firms can deliver superior value to their target segments, by following three value principles: (i) operational excellence which delivers superior value by leading price and convenience; (ii) by tailoring products and services to exactly match targeted customers' needs termed customer intimacy, responding quickly to changing needs; and (iii) by offering a stream

\begin{tabular}{|c|c|c|}
\hline \multirow[t]{4}{*}{$\begin{array}{l}\text { Segments or } \\
\text { markets }\end{array}$} & Market share (revenue \%) (RMS) & $\begin{array}{l}\text { Number of sales or gross sales revenue by } \\
\text { market segment as a } \% \text { of total market } \\
\text { sales or size }\end{array}$ \\
\hline & Relative market share (RMS) & $\begin{array}{l}\text { Compare market share between top } 5 \\
\text { competitors }\end{array}$ \\
\hline & Competitiveness (comp) & $\begin{array}{l}\% \text { customers for whom the firm is the first } \\
\text { choice supplier or } \% \text { market sectors in } \\
\text { which the firm is the first choice supplier }\end{array}$ \\
\hline & Market contribution (MC) & $\begin{array}{l}\text { Measure concentration, growth, and } \\
\text { trends }\end{array}$ \\
\hline \multirow[t]{4}{*}{ Orders } & Market penetration (MP) & $\begin{array}{l}\text { Numbers of orders (per segment) as } \\
\text { a percentage of total orders' overall } \\
\text { categories }\end{array}$ \\
\hline & New product adoption (NPA) & $\begin{array}{l}\% \text { of sales turnover that is generated } \\
\text { from new products/services in a given } \\
\text { time period OR the } \% \text { of orders that is } \\
\text { generated from new products/services in a } \\
\text { given time period }\end{array}$ \\
\hline & Customer relationships (CRM) & $\begin{array}{l}\text { Customer contact, e.g., number of } \\
\text { contacts between staff and key customers. } \\
\text { This provides an indication of the strength } \\
\text { of the relationship being developed in the } \\
\text { segment }\end{array}$ \\
\hline & New customer acquisition (CU) & $\begin{array}{l}\text { Number of new customers over the past } \\
\text { year as a } \% \text { of a number of customers in } \\
\text { total or value of new customer sales as a } \% \\
\text { of total sales }\end{array}$ \\
\hline \multirow[t]{4}{*}{ Customers } & Customer experience index (CXI) & $\begin{array}{l}\text { Combine various CX values to the firm } \\
\text { such as satisfaction, retention, and } \\
\text { referrals }\end{array}$ \\
\hline & Share of wallet \% (SoW) & $\begin{array}{l}\text { The firm's share of addressable spent by } \\
\text { customers in the segment }\end{array}$ \\
\hline & Customer loyalty \% (CLTV) & $\begin{array}{l}\text { Quantify from an aggregation of loyalty } \\
\text { measures such as repeat purchases, the } \\
\text { number of different products purchased, } \\
\text { relationship duration, and loyal customers }\end{array}$ \\
\hline & $\begin{array}{l}\text { Returns per customer per segment } \\
\text { (RoR) }\end{array}$ & $\begin{array}{l}\text { Average ratio of returns per customer over } \\
\text { a specified period: } 30 / 60 / 90 \text { days }\end{array}$ \\
\hline
\end{tabular}




\begin{tabular}{|c|c|c|}
\hline \multirow[t]{3}{*}{ Channels } & Expense per revenue \% (E/R) & Expense and revenue of each channel \\
\hline & Channel mix \% (CM) & Channel concentration and growth trends \\
\hline & Channel performance/plan (CPP) & $\begin{array}{l}\text { Channel performance vs. budget/forecast/ } \\
\text { event/plan }\end{array}$ \\
\hline \multirow[t]{3}{*}{ Offerings } & Offering \% & $\begin{array}{l}\text { Year-over-year performance of each } \\
\text { offering (product/service) }\end{array}$ \\
\hline & Profitability \% per offering $(\mathrm{P} / \mathrm{O})$ & $\begin{array}{l}\text { Realization of value message in the } \\
\text { profitability of purchases }\end{array}$ \\
\hline & Revenue $\%$ of new offerings (R/NO) & $\begin{array}{l}\text { Use period of a typical life cycle of a client } \\
\text { (can be }<1 \text { year) }\end{array}$ \\
\hline \multirow{3}{*}{$\begin{array}{l}\text { Unique value } \\
\text { proposition }\end{array}$} & Win ratio $\%$ (wins/C) & How many new clients or $\$$ do we win? \\
\hline & Competitive replacement \% (CR) & Are you able to displace the competition? \\
\hline & Margin $\%$ trends (margin $\mathrm{T}$ ) & Gross, operating, and net value \\
\hline
\end{tabular}

Table 3.

Quantitative measure of segmentation success.

of innovative, leading-edge products and services through relentless pursuit of new solutions relevant for the firm's focus segments, labeled product leadership. An example of operational excellence (lowest net-land cost) and customer intimacy excellence comes from office stationery supplier Staples USA. This chain focuses on a particular segment, namely, SMEs with fewer than 50 staff, and builds customer intimacy through loyalty cards and a club. Every time buyers use the card-which they need to access the discount-Staples capture data that allows the firm to monitor changing needs and applications and respond immediately to innovate to satisfy the market.

Constant evaluation and re-evaluation of each segment ensure that the firm does not waste resources on segments that will not value your firm's offerings or do business with the brand. Adept markets are clear on the need to match the characteristics of the marketing segment to the qualities of their product offering(s) and the abilities of the firm to achieve sales performance objectives through a segmented marketing plan (STP).

There are both qualitative and quantitative tests to select, monitor, and control the MSP. Qualitative tests relate to the alignment with the firm's vision, mission, and competitive positioning. Further qualitative tests relate to the four main questions, namely, "Do consumers in the segment (in both B2C and B2B segmentation plans) see our firm, its brand, and the products in the same light as the firm does, and vice versa?" In other words, “Do customers' comments, reviews, responses, and other forms of communication (WOM) add to (or distract from) the unique positioning the firm envisages for its UVP and brand positioning? Are the selected marketing (sales, distribution, and communication) channels well aligned with customer channel preferences? A fourth question about the selected marketing and communication channels is: Can the channel handle consumer demands and two-way dialog?"

In terms of implementation, marketers need to develop and monitor the firm's ability to communicate the desired positioning of the firm to target customers. Also, controls need to establish if all the firm's efforts in the marketing mix support the MSP and positioning strategy (and vice versa).

Basic customer/market/sales quantitative performance and process measures applied to the firm's targeted segments can provide measurements and an indication of success. Quantitative measures are specific to a particular firm, its selection of target segments and the firm's channels, and sales and distribution practices. Further quantitative measures to determine segmentation success are set out in Table 3 and cover the four areas of markets, customers, channels, offerings, and value propositions. 


\subsubsection{Measure success to control innovation and reset targets}

Set out below are some of the measures that are relevant to determine if a target segment is viable and likely to generate profitable business in the long term. These measures link well with the MADD MACC model discussed earlier and are used by marketers to assess their segmentation and target market plans.

1. Responsiveness: homogeneous, unique response within a segment, heterogeneous between segments.

2. Actionability: segments and firm's goals/competencies should match.

3. Substantiality: segments should be large enough.

4.Identifiability: easily measurable segmentation variables.

5. Accessibility: effective promotional/distributional tools needed.

6. Stability: composition of segments should not change rapidly.

\section{Conclusion}

Market segmentation will become more complex and more varied as the solutions consumers need and are able to demand become more easily available and more globally diverse. Understanding the challenges, opportunities, and the complexity of factors to consider will therefore become even more important to marketers. Unfortunately there is no one recipe to suit all products, all firms, or even similar segments. The success of marketing interventions is likely to depend on marketers' ability to gather consumer insights, firms' ability to adapt and innovate fast to become and remain the provider of preference, and constantly collaborating with various stakeholders to co-create solutions of value to target audiences. With a marketplace of more than 7 billion people, constant innovation will be the only constant, and marketers will constantly need to find new ways to understand, influence, and provide value to a wide range of divergent markets.

\section{Appendix: list of brands in alphabetical order}

\begin{tabular}{ll}
\hline Advil & L'Oreal \\
\hline AirBnB & Lyft \\
\hline Amazon & Maybelline \\
\hline Android smartphones & Mercedes \\
\hline Apple & MSC Cruises \\
\hline BMW & New World \\
\hline Boeing & Orbit Travel \\
\hline BTS & Pack'n Save \\
\hline Budweiser & Pam Golding \\
\hline Coca-Cola & Pepsi \\
\hline
\end{tabular}




\begin{tabular}{|c|c|}
\hline Colgate & Pinterest \\
\hline Constant Comedy.com & Prosecco \\
\hline Cosco & $P \& G$ \\
\hline Dell & Qantas \\
\hline DeSpar & Radian6 \\
\hline Disprin & Range Rover \\
\hline DHL & Ray Ban \\
\hline Dreamliner & Ray White Properties \\
\hline Dry Bar Comedy & Red Bull \\
\hline Etsy Inc. & Reuters \\
\hline Facebook & Salesforce \\
\hline FedEx & Samsung \\
\hline Flickr & Schwarzkopf \\
\hline Flight Star & Sony, Sony Walkman \\
\hline Foodstuff & SPAR \\
\hline Gap NY & Staples USA \\
\hline$G E$ & Tesco \\
\hline General Life (Insurance) & TradeMe \\
\hline Google; Google Plus, Google Circles; Google Analytics & TV10 \\
\hline Hallmark & Twitter \\
\hline $\mathrm{HBO}$ & Tylenol \\
\hline HSBC Banks & University of Sydney, Australia \\
\hline Instagram & VOLVO \\
\hline K-Pop & Vox News \\
\hline Lacta & Walmart \\
\hline Levis's & Wendy's \\
\hline Lexus & WriteWell \\
\hline LinkedIn & YouTube \\
\hline
\end{tabular}

\section{Author details}

Rouxelle de Villiers*, Pornchanoke Tipgomut and Drew Franklin Auckland University of Technology, Auckland, New Zealand

*Address all correspondence to: rdevilli@aut.ac.nz

\section{IntechOpen}

(C) 2019 The Author(s). Licensee IntechOpen. This chapter is distributed under the terms of the Creative Commons Attribution License (http://creativecommons.org/licenses/ by/3.0), which permits unrestricted use, distribution, and reproduction in any medium, provided the original work is properly cited. (cc) BY 


\section{References}

[1] American Marketing Association. Definitions of Marketing [Internet]. 2019. Available from: https://www. ama.org/the-definition-of-marketing/ [Accessed: 16 May 2019]

[2] Volvo Car Group. Our Mission and Vision [Internet]. 2019. Available from: https://www.volvogroup.com/en-en/ about-us/our-mission-and-vision.html [Accessed: 12 May 2019]

[3] Kotler P. Marketing Management. Upper Saddle River, NJ: Prentice-Hall; 2003

[4] Byrne C. A New Front Is Opened Up in the Cola Wars: Diet-Conscious Men [Internet]. 2005. Available from: https:// www.independent.co.uk/news/a-newfront-is-opened-up-in-the-cola-warsdiet-conscious-men-5384904.html [Accessed: 14 May 2019]

[5] Salesforce. See What Salesforce Can Do for Your Company [Internet]. 2019. Available from: https://www.salesforce. com/au/form/sem/crm-demo_b/ [Accessed: 12 May 2019]

[6] Vijayenthiran V. BMW's New Ad Slogan Is "Designed for Driving Pleasure": Video [Internet]. 2013. Available from: https://www.motorauthority.com/ news/1082409_bmws-new-ad-sloganis-designed-for-driving-pleasure-video [Accessed: 14 May 2019]

[7] Ries A, Trout J. The 22 Immutable Laws of Marketing. London, UK: Profile Books Limited; 1994

[8] Romano A. BTS, the Band that Changed K-Pop, Explained [Internet]. 2019. Available from: https://www.vox. com/culture/2018/6/13/17426350/btshistory-members-explained [Accessed: 10 May 2019]

[9] Perry B. Enterprise Operations. Burlington, MA: CIMA Publishing; 2009
[10] Gilligan C, Wilson RMS. Strategic Marketing Planning. 2nd ed. New York, NY: Taylor \& Francis Group; 2009

[11] Olsen D. Groupon Clone 'Ourdeal' Gets Investment from Network Ten [Internet]. 2010. Available from: https:// www.dynamicbusiness.com.au/news/ groupon-ourdeal-network-ten-2191. html [Accessed: 16 May 2019]

[12] Lee J. Daily Deals, and They're Done Dirt Cheap [Internet]. 2010. Available from: https://www.smh.com. au/business/companies/daily-dealsand-theyre-done-dirt-cheap-201012281998w.html [Accessed: 16 May 2019]

[13] Peppers D, Rogers M. The One to One Future: Building Relationships One Customer at a Time. New York, NY: Crown Business; 1993

[14] Welch J, Byrne JA. Jack: Straight from the Gut. New York, NY: Warner Books, Inc.; 2003

[15] BMW ConnectedDrive. The New BMW Connected Drive Packages [Internet]. 2019. Available from: https:// www.bmw-connecteddrive.co.za/ app/index.html?gclid=CjwKCAjwqqrm BRAAEiwAdpDXtCpj7CGoDq WUNnoyqNANQhsKZdIrfyJo 5SPduJx6eQaCtICgrnqdvho CAwkQAvD_BwE\#/portal/store [Accessed: 09 May 2019]

[16] Wind Y, Cardozo RN. Industrial market segmentation. Industrial Marketing Management. 1974;3(3):153-165

[17] Biemans WG. Business to Business Marketing: A Value-Driven Approach. London, UK: McGraw-Hill Education; 2010

[18] Bonoma TV, Shapiro BP. Segmenting the Industrial Market. Lexington, MA: Lexington Books; 1983 
[19] Solberg CA. International Marketing: Strategy Development and Implementation. 1st ed. New York, NY: Routledge; 2018

[20] Maps of World. What are the Top 10 Iron Ore Producing Nations? [Internet]. 2018. Available from: https://www. mapsofworld.com/answers/economics/ top-10-iron-ore-producing-nations/ [Accessed: 16 May 2019]

[21] Maps of World. Top 10 Mango Producing Countries in the World [Internet]. 2018. Available from: https:// www.mapsofworld.com/world-topten/mango-producing-countries.html [Accessed: 20 May 2019]

[22] Yarns and Fibers. Wool Industry in New Zealand [Internet]. 2010. Available from: http://www.yarnsandfibers.com/ preferredsupplier/reports_fullstory. php?id =548\&section $=\&$ p type $=$ Wool\&country $=$ New $\% 20 Z$ Zealand [Accessed: 16 May 2019]

[23] Yarns and Fibers. World Cotton Fibre-Trend in Demand \& Supply 2015 [Internet]. 2016. Available from: http:// www.yarnsandfibers.com/industryreport/2015/world-cotton-report [Accessed: 10 May 2019]

[24] Coca Cola Journey. Coca-Cola At A Glance: Infographic [Internet]. 2018. Available from: https://www. coca-colacompany.com/our-company/ infographic-coca-cola-at-a-glance [Accessed: 16 May 2019]

[25] Samsung Newsroom. About Us: Fast Facts [Internet]. 2019. Available from: https://news.samsung.com/global/fastfacts [Accessed: 05 June 2019]

[26] International Society of Gynecological Endocrinology. List of Developing Countries [Internet]. 2019. Available from: https://isge2018. isgesociety.com/registration/list-ofdeveloping-countries/ [Accessed: 16 May 2019]
[27] Diabat A, Govindan K, Panicker VV. Supply chain risk management and its mitigation in a food industry. International Journal of Production Research. 2012;50(11):3039-3050

[28] Avraham E. Destination image repair during crisis: Attracting tourism during the Arab spring uprisings. Tourism Management. 2015;47:224-232

[29] Stepchenkova S, Eales JS.

Destination image as quantified media messages: The effect of news on tourism demand. Journal of Travel Research. 2011;50(2):198-212

[30] The Sydney Morning Herald. Vice-Chancellor Warns of Falling Chinese Student Numbers [Internet]. 2019. Available from: https://www. universityworldnews.com/post. php?story $=20190309050636603$ [Accessed: 22 May 2019]

[31] Luxottica. Ray-Ban [Internet]. 2019. Available from: http://www.luxottica. com/en/eyewear-brands/ray-ban [Accessed: 16 May 2019]

[32] Luxottica. Ray-Ban Studios: Feel Your Beat [Internet]. 2019. Available from: http://www.luxottica.com/en/rayban-studios-feel-your-beat [Accessed: 10 May 2019]

[33] Cummins S, Peltier JW, Schibrowsky JA, Nill A. Consumer behavior in the online context. Journal of Research in Interactive Marketing. 2014;8(3):169-202

[34] Forbes LP, Vespoli EM. Does social media influence consumer buying behavior? An investigation of recommendations and purchases. Journal of Business \& Economics Research. 2013;11(2):107-112

[35] Alghalith N. Web analytics: Enhancing customer relationship management. Journal of Strategic Innovation and Sustainability. 2015;10(2):11 
[36] Liu Y, Li H, Peng G, Lv B, Zhang C. Online purchaser segmentation and promotion strategy selection: Evidence from Chinese E-commerce market. Ann. Oper. Res. 2015;233(1):263-279

[37] Chen Y, Xie J. Online consumer review: Word-of-mouth as a new element of marketing communication mix. Management Science.

2008;54(3):477-491

[38] Hennig-Thurau T, Hofacker CF, Bloching B. Marketing the pinball way: Understanding how social media change the generation of value for consumers and companies. Journal of Interactive Marketing. 2013;27(4):237-241

[39] Anderson M. 88\% of Consumers Trust Online Reviews As Much As Personal Recommendations [Internet]. 2014. Available from: https:// searchengineland.com/88-consumerstrust-online-reviews-much-personalrecommendations-195803 [Accessed: 09 May 2019]

[40] Vendasta. The Top 10 Review Websites [Internet]. 2019. Available from: https://www.vendasta.com/ content-library/confirmationredirect/?url=top-10-review-websites [Accessed: 05 May 2019]

[41] Popp B, Germelmann CC, Jung B. We love to hate them! Social media-based anti-brand communities in professional football. International Journal of Sports Marketing and Sponsorship. 2016;17(4):349-367

[42] Hollenbeck CR, Zinkhan GM. Antisbrand communities, negotiation of brand meaning, and the learning process: The case of Wal-Mart. Consumption, Markets and Culture. 2010;13(3):325-345

[43] Youtube. Dove Evolution [Internet]. 2013. Available from: https://www. youtube.com/watch?v=eNoo-ivduNw [Accessed: 16 May 2019]
[44] Flickr. Stop Dove Destroying Rainforests [Internet]. 2019. Available from: https://www.flickr.com/groups/ stopdove/pool/ [Accessed: 21 May 2019]

[45] Youtube. Dove Onslaught(er) [Internet]. 2008. Available from: https:// www.youtube.com/watch?v=odI7pQ Fyjso\&gl=GB\&hl=en-GB [Accessed: 04 May 2019]

[46] Consumer Affairs. Airbnb [Internet]. 2019. Available from: https:// www.consumeraffairs.com/travel/ airbnb.html [Accessed: 16 May 2019]

[47] Dallaire J. Home Depot Shows the Pains and Gains of DIY [Internet]. 2018. Available from: http://strategyonline. ca/2018/05/22/home-depot-shows-thepains-and-gains-of-diy/ [Accessed: 16 May 2019]

[48] Bhattacharyya S. How Home Depot Is Driving People Back Into Its Stores [Internet]. 2018. Available from: https:// digiday.com/retail/home-depot-drivingpeople-back-stores/ [Accessed: 06 May 2019]

[49] Brenzel H. 5 Creative Ways Top Brands Use Long-Form Video [Internet]. 2014. Available from: https://www. viralgains.com/resources/pressblog/2014/02/5-creative-ways-brandslong-form-video/ [Accessed: 16 May 2019]

[50] Tinseth R. Behind the Scenes Story on Naming the Dreamliner [Internet]. 2018. Available from: https://randy. newairplane.com/2011/03/28/behindthe-scenes-story-on-naming-thedreamliner/ [Accessed: 01 May 2019]

[51] O’Dea A. Innovation. Marketing Age. 2008 (September/October)

[52] InnoCentive. Challenge Center [Internet]. 2019. Available from: https:// www.innocentive.com/ar/challenge/ browse [Accessed: 16 April 2019] 
[53] Youtube. Dry Bar Comedy. [Internet] 2019. Available from: https://www.youtube.com/channel/ UCvlVuntLjdURVD3b3Hx7kxw [Accessed: 20 April 2019]

[54] Marsello. Marketing Automation Features Designed to Increase Sales \& Loyalty at Every Stage of the Customer Lifecycle [Internet]. 2019. Available from: https://www.marsello.com/ features [Accessed: 22 April 2019]

[55] ViaPoint. Market Segmentation: How Does It Work with Online Social Networks? [Internet]. 2019. Available from: https://marketingtechnews.net/ media/1440-viapoint-paulfennemore. pdf [Accessed: 23 April 2019]

[56] Smith PR, Zook Z. Marketing Communications: Integrating Offline and Online with Social Media. 5th ed. Kogan Page; 2011

[57] Baldwin C. Twitter Helps Dell Rake in Sales [Internet]. 2009. Available from: https://www.reuters.com/article/ us-twitter-dell/twitter-helps-dell-rakein-sales-idUSTRE55B0NU20090612 [Accessed: 20 April 2019]

[58] Hamilton A. What Are Your e-Shopping Habits? [Internet]. 2000. Available from: https://www.zdnet. com/article/what-are-your-e-shoppinghabits/ [Accessed: 23 April 2019]

[59] Keng Kau A, Tang YE, Ghose S. Typology of online shoppers. Journal of Consumer Marketing. 2003;20(2):139-156

[60] Bhatnagar A, Ghose S. A latent class segmentation analysis of e-shoppers. Journal of Business Research. 2004;57(7):758-767

[61] Day GS. Market Driven Strategy: Processes for Creating Value. New York, NY: Free Press; 1990
[62] Blocker CP, Flint DJ. Exploring the dynamics of customer value in crosscultural business relationships. Journal of Business \& Industrial Marketing. 2007;22(4):249-259

[63] Harrison D, Kjellberg $H$.

Segmenting a market in the making: Industrial market segmentation as construction. Industrial Marketing Management. 2010;39(5):784-792

[64] Motor Trend Staff. 2019 Toyota RAV4 Adventure First Test: Shy Torque Vectoring [Internet]. 2018. Available from: https://www.msn.com/en-ca/ autos/research/2019-toyota-rav4adventure-first-test-shy-torquevectoring/ar-BBRqNAS [Accessed: 16 April 2019]

[65] Etsy. Etsy, Inc. Reports Fourth Quarter and Full Year 2018 Financial Results [Internet]. Cision PR Newswire. 2019. Available from: https://www. prnewswire.com/news-releases/etsyinc-reports-fourth-quarter-and-fullyear-2018-financial-results-300801469. html [Accessed: 20 April 2019]

[66] Day GS. The product life cycle: Analysis and applications issues. Journal of Marketing. 1981;45(4):60-67

[67] Rogers EM. Diffusion of Innovations. 5th ed. New York, NY: Simon \& Schuster; 2003

[68] Baughman JP. Problems and Performance of the Role of the Chief Executive in General Electric. Internal Report; 1974

[69] Levitt T. Marketing Myopia [Internet]. 2004. Available from: https://hbr.org/2004/07/marketingmyopia [Accessed: 02 May 2019]

[70] Hlavacek JD, Ames BC. Segmenting industrial and high-tech markets. Journal of Business Strategy. 1986;7(2):39-50 
[71] Freytag PV, Clarke AH. Business to business market segmentation. Industrial Marketing Management. 2001;30(6):473-486

[72] Vintage Ad Browser. Electronics/TV of the 1980s [Internet]. 2019. Available from: http://www.vintageadbrowser. com/electronics-ads-1980s/5 [Accessed: 04 May 2019]

[73] APKPot. Sony Walkman Music Player App Latest APK v9.3.7.a.1.2 for Android Free Download [Internet]. 2017. Available from: https://www. apkpot.net/apk/sony-walkman-musicplayer-app/ [Accessed: 09 May 2019]

[74] Dibb S, Simkin L. Market segmentation: Diagnosing and treating the barriers. Industrial Marketing Management. 2001;30(8):609-625

[75] De Villiers R. Sources of Sustainable Competitive Advantage for Businesses Operating in a Global Marketplace. University of Pretoria; 2001

[76] Volvo Car Group. About Our Company [Internet]. 2019. Available from: https://group.volvocars.com/ [Accessed: 02 May 2019]

[77] AutoTrader. BMW [Internet]. 2019. Available from: https://www.autotrader. com/BMW/2019 [Accessed: 11 May 2019]

[78] Rice-Oxley M. Vorsprung Durch Technik-Ad Slogan that Changed How We Saw Germany [Internet]. 2012. Available from: https://www. theguardian.com/world/2012/sep/18/ vorsprung-durch-technik-advertisinggermany [Accessed: 04 May 2019]

[79] World Airline Awards. Best Airlines 2018 by Region [Internet]. 2019. Available from: https://www. worldairlineawards.com/best-airlines2018-by-region/ [Accessed: 02 May 2019]
[80] Schwarzkopf. Our Brands

[Internet]. 2019. Available from: http:// www.schwarzkopf.com/en/home.html [Accessed: 08 May 2019]

[81] Tynan C, McKechnie S, Chhuon C. Co-creating value for luxury brands. Journal of Business Research. 2010;63(11):1156-1163

[82] Kim WC, Mauborgne R. Knowing a Winning Business Idea When You See One [Internet]. 2000. Available from: https://hbr.org/2000/09/knowing-awinning-business-idea-when-you-seeone [Accessed: 16 May 2019]

[83] Brunn P, Jensen M, Skovgaard J. e-marketplaces: Crafting a winning strategy. European Management Journal. 2002;20(3):286-298

[84] Symmetrics. A Go-To-Market (GTM) Strategy Primer. Available from. http://symmetricsgroup.com/a-go-tomarket-strategy-primer/ [Accessed: 19 May 2019]

[85] Tracey M, Wiersema F. Customer Intimacy and Other Value Disciplines. Harvard Business Review; 1993. pp. 84-93

[86] Treacy M, Wiersema F. The Discipline of Market Leaders: Choose your Customers, Narrow your Focus, Dominate your Market. Basic Books; 2007 



\title{
Repositioning of PR Field in Developing Countries
}

\author{
Anıl Kemal Kaya and Umut Ayman
}

\begin{abstract}
There is a big question in the market whether companies are giving a real equity for public relations (PR) field in developing countries. In developing countries, unfortunately, managers are not giving full support for PR professional in their institutions. Companies apply some of the marketing communication (MC) elements while trying to reach their target market and focus on the elements that can show performance in a short term, mostly because they want to return their investment in a short term. Advertising and sales promotion activities are measurable in a short run, and PR and sales force performance are measured in a long run; hence, companies prefer to allocate their budget more for their shortterm activities than long-term activities because they perceive all as extra cost, which is not true. Thus, managers have to believe that MC campaign is not an extra cost and that it is a type of communication investment for good corporate image and reputation for the public. This chapter is emphasizing what PR professionals are doing in their fields will be discussed in detail. Thus, this chapter is important because it is guiding the companies that have operations in developing countries about what they will expect from their PR professional when they build on their strategic communication.
\end{abstract}

Keywords: public relations, strategic communication, backbone, developing countries

\section{Introduction}

In many PR books, PR is defined as a backbone for the companies that create mutual understanding with stakeholders; if so why are companies in developing countries not seeing PR as a backbone in their institutions? One of the reasons is that there is a confusion or misunderstanding about PR field. The main confusion is that managers think that PR only care about customer relationship and receive the customers with smiling faces so there is no need to get specialized in that field as it only depends on personal skills. However they are doing more things than that. PR professionals are the ones that plan the whole strategic communication of the company while trying to communicate to the public in the long run. They are the ones who solve crises; they are the ones who create corporate reputation and brand image in correspondence with their strategic communication plan. For this context, the PR's primary roles, functions, and tactics help to understand the field of PR. 


\section{A hierarchy of PR's primary roles, functions, and tactics}

Hutton [1] pointed out the hierarchical strategy and tactics of PR with its roles and functions for managing strategic relationships in the context of framework. PR is defined as managing strategic relationships and building communicative bridge with the company and not only customers but also stakeholders. PR professionals have some situational roles to affect, persuade, advocate, educate, and crusade people and be highly responsible to give the right information as well as manage the reputation of the company.

The primary functions of PR cover research, image and communication, interpreting and negotiating, counseling aspects and managerial functions, and seeing and interpreting the threats for the company. PR professionals are responsible for these functions, and they create a mutual understanding and communication with stakeholders by using the tactical tools of the company as shown in Table 1.

Therefore, public relations must be discussed under managerial level. There is so much discussion about what PR professionals are doing in the market and what sort of background knowledge they must have. Anybody can act as PR professional without having specialization in the PR field. If companies need an effective and efficient company image, company reputation, and good corporate communication no matter in which sector they are in, they must hire at least one PR professional in their company.

\begin{tabular}{ll}
\hline Definition & "Managing strategic relationships" \\
\hline Situational roles & Persuader, advocate, educator, crusader, information provider, reputation manager. \\
\hline $\begin{array}{l}\text { Primary functions } \\
\text { performed }\end{array}$ & $\begin{array}{l}\text { Research, image making, counseling, managing, early warning, interpreting, } \\
\text { communicating, negotiating. }\end{array}$ \\
\hline Tactics/tools utilized & $\begin{array}{l}\text { Publicity, product placements, news releases, speeches, interpersonal } \\
\text { communications, web sites, publications, trade shows, corporate identity programs, } \\
\text { corporate advertising programs, etc. }\end{array}$ \\
\hline Source: Hutton [1], p. 211. &
\end{tabular}

Table 1.

Primary roles, functions, and tactics of $P R$.

\section{PR professional importance in the sector}

PR professionals are the ones who act as intermediary between the company that they work and the public, and they are also preparing the company strategic communication plan under nine steps as follows:

Step 1: Examine the situation analysis.

Step 2: Evaluate the organization.

Step 3: Investigate the publics.

Step 4: Set up goals and objectives.

Step 5: Put into word the action and response strategies.

Step 6: Use effective communication.

Step 7: Choose communication tactics.

Step 8: Apply the strategic plan.

Step 9: Measure the performance of the strategic plan [2]. 
According to these sequential steps, the first three steps, examining the situation analysis, evaluating the organization, and investigating the publics, are related with research. Situation analysis is one of the important steps in scanning internal and external environment to examine what is going on in the sector. Research about the internal environment is the evaluation of the organization and investigating publics is to understand the stakeholders' point of views with research. Steps 4, 5, and 6 are about strategy, which are setting up goals and objectives and then determining the action and response strategies with the use of effective communication. So, steps 7 and 8 are about tactics which the company selects, then put into action, and which the company use to transfer their communication to reach various stakeholder groups. The last step is about evaluation of strategic communication campaign. Every company has to have their own strategic plan to reflect accurately their corporate identity to the public. With the effective strategic plan and with a good corporate communication, the company can create good company image and reputation among public. In other words corporate identity can be defined as, "the reality and uniqueness of an organization which is integrally related to its external and internal image and reputation through corporate communication" [3, 4]. Having a good image and reputation helps company to differentiate themselves from their competitors by gaining a competitive advantage. As seen in the figure below, PR professionals have a chance to get a feedback from the target audience group about what they think about the company, what the company position is in the stakeholders' mind, and how stakeholder group perceives the company, and if there is any need for modification for their strategy, they may have a chance to modify or reshape it. In other words, according to the strategic communication evaluation, if PR professionals are aware of the fact that there is any negative image or bad reputation, they have to take actions to rebuild the company image. While managing corporate communication, PR professional has to build an accurate strategic communication by caring about the company's identity. Since every company has a different identity, that makes them different from the other companies, and identity comes into existence with the combination of company's mission(s), vision(s), value(s), and organization culture elements (Figure 1).

Stakeholders can be defined as public as well. Then public is categorized under four main headlines such as:

a. Customer: the people that have a chance to get the company's products or services. Customers can be current, potential, secondary, and shadow constituencies.

b.Producers: the people that provide any inputs for the companies to produce their products or services. Suppliers, personnel (employees, volunteers), and financiers (donors, stockholders) can be categorized as producers.

c. Limiters: the people that reduce or weaken the company's success such as competitors, opponents, and hostile forces.

d.Enablers: the people that influence company's success in the market such as media, allies, opinion leaders, and regulators ([2], p. 59).

While preparing for an effective strategic communication campaign, the PR professional has to perfectly define the key (strategic) to appeal to the public perfectly. These people are named as target audience whom PR professionals try to create an effective and efficient communication with. As they are so important, PR professional has to know these groups perfectly (Table 2 ). 


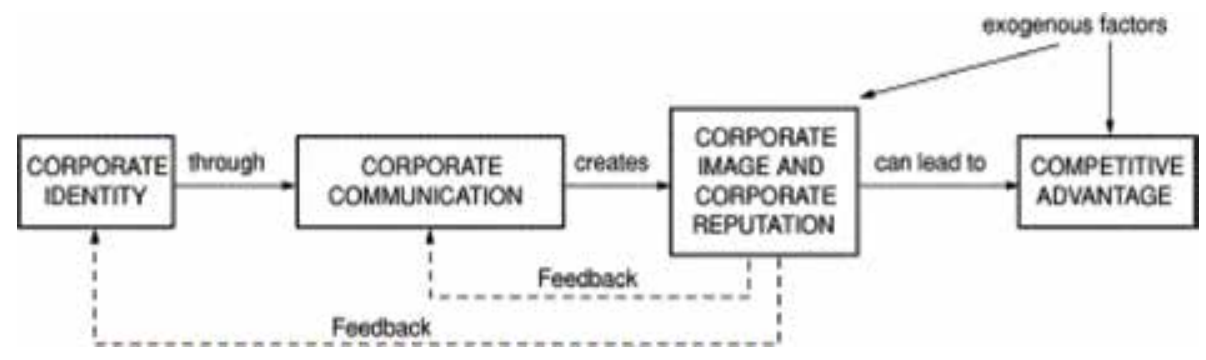

Figure 1.

Stages for company's competitive advantage [3-5].

To define an accurate key (strategic) public, follow the process

Customers

1. Define your company's primary customers (who use the company's product/service mainly?)

2. Define your secondary customers

3. What sort of changes you saw from your customer within the past years?

4. What sort of changes may happen from your customers within the coming years?

Producers

1. Define your supplier that produces some services/products for your company

2. Categorize your employees and define them perfectly

3. Define your volunteers if you have any

4. Who provides money for your company? Categorize these providers

5. What sort of changes you saw from your producers within the past years?

6. What sort of changes may happen from your producers within the coming years?

Enablers

1. Define who are the opinion leaders among your customers

2. Define who are the allies among your company

3. Define the regulators for your company

4. How have regulators helped you within the last 3 years?

5. Identify for whom are the contracts or agreements in your company

6. Define the media channels that your company uses mostly

7. What sort of changes you saw from your enablers within the past years?

8. What sort of changes may happen from your enablers within the coming years?

Limiters

1. Define your company's competitors

2. Define your company's opponents and categorize them

3. Define which limiters group either stops or slows down your company success mostly

5 . What sort of changes you saw from your limiters within the past years?

6. What sort of changes may happen from your limiters within the coming years?

Source: Smith [2], pp. 64-65.

Table 2.

Knowing public.

Then PR professionals perfectly define the key public in detail; this helps PR professionals to put the accurate strategy and tactics to reach their short-term and long-term objectives. No matter either short- or long-term objectives, objectives have to be specific, measurable, accurate, achievable, and time specific. 
In order to put effective and accurate objectives, PR professional has to do SWOT analysis of the company in a realistic way. In developing countries the main problem for the companies is that they do not realistically analyze their weak point; therefore while building strategic communication, their plan may not be effective. After accurate objective setting, PR professional has to put accurate strategy.

Strategy is the guideline that shows the plan of action that has to be applied to achieve the objectives. According to the objectives and situations, PR professional has a role; they do both proactive $\mathrm{PR}$ and reactive $\mathrm{PR}$ in the company.

Proactive $\mathrm{PR}$ is focusing more on brand, company image, and reputation. The main aim of proactive PR is to build trustworthy reputation of the company's brand among the public. On the other hand, reactive PR is focusing more on crisis-based issues either to minimize it or to stop it. While applying reactive PR, PR professional tries to minimize the damage to the company image by applying the right plan, and then if crises happen, they solve them and they concentrate on rebuilding trust. Building a good company image and reputation takes many years, but losing it takes seconds especially in this new age. Thus companies have to do the right thing, in the right time with both proactive $P R$ and reactive $P R$, not to lose their competitive advantage.

As shown in Table 3, proactive PR and reactive PR have different purposes and are applied by the companies' PR professional. Also just applying the right strategies and tactics are not enough; PR professional has to evaluate the outcomes during the strategic plan communication. Using different methodologies, PR professional may have a chance to measure the outcomes of that strategic communication (Figure 2).

As seen in the above figure, Macnamara model shows three stages as inputsoutputs and outcomes. The input stage focuses on formative research that evaluates the organization and the public, and the situation analysis is done by using different methods such as expert analysis, case studies, and observation. In formative research, PR professionals establish the communication goals and objectives by using SMART technique, and then in accordance with these objectives, strategies and tactics are applied using both quantitative and qualitative methodology results. As that type of strategic communication plans is costly, just applying it is not enough for the companies. In developing countries, mostly they implement the tactics somehow, but during the evaluation of outcomes, either they do not know how to apply it or they are not aware of the importance of the measurement of the campaign.

\begin{tabular}{ll}
\hline Proactive public relation strategies & Reactive public relations strategies \\
\hline Action strategies & - Preemptive action strategy: prebuttal \\
- Organizational performance & - Offensive response strategies: attack, embarrassment, threat \\
- Audience participation & - Defensive response strategies: denial, excuse, justification \\
- Special events & - Diversionary response strategies: concession, ingratiation, \\
- Alliances and coalitions & disassociation, relabeling \\
- Sponsorships & - Vocal commiseration strategies: concern, condolence, regret, \\
- Activism & apology \\
Communication strategies & Rectifying behavior strategies: investigation, corrective action, \\
- Newsworthy information & restitution, repentance \\
- Transparent communication & Strategic inaction: silence \\
\hline Source: Smith $[2], p .83$ and 98. & \\
\hline
\end{tabular}

Table 3.

Proactive-reactive PR strategies. 


\section{'Pyramid Model' of PR Research}

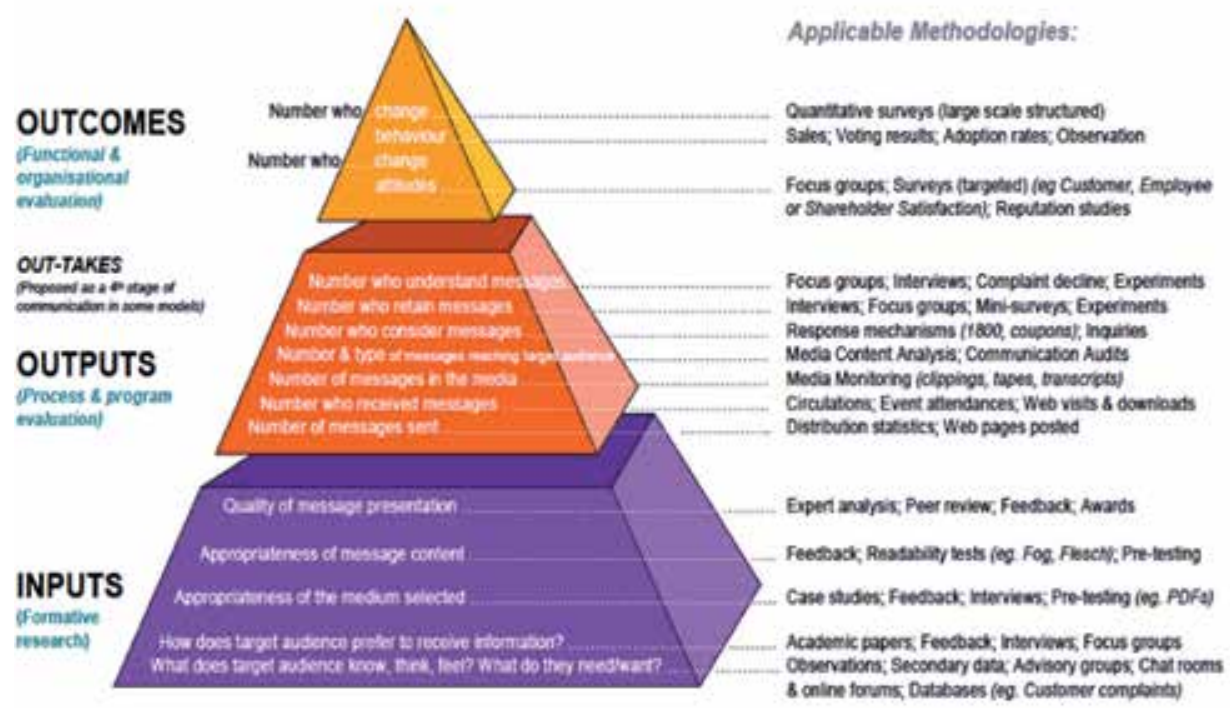

Figure 2.

Macnamara model ([6], p. 304) ([7], p. 85).

\section{Four models of PR called as Grunig and hunt model}

Four models of PR by Grunig and Hunt (1984) have explained the role of PR in management with its functions. Grunig and Hunt (1984) are the scholars who firstly explained the four characteristics of PR into practices in the model [8].

1. Press agent/publicity: the purpose is propaganda, which is used for persuasion. It is half trust and manipulation to influence audience to behave as the organization desires as there is little research done in this field. It is complete truth but not essential, and while reaching audience they use one-way communication which means they just send their message without getting any feedback mostly practiced in sports, theater, and product promotion field.

2. Public information: the purpose is dissemination of information, and it uses press release and other types of one-way communication channel techniques that send organizational information. Here PR professionals act as journalist in the company. Like press agent model, in this model, there is little and informal research done as well, and while communicating to their audience, they use one-way communication but the message is true and important; therefore it is readership and readable. It is practiced generally in governmental institutions and nonprofit associations.

3. Two-way asymmetric: the purpose is scientific persuasion which uses persuasion and manipulation to influence audience to behave as the organization desires. It conducts formal research and incorporates audience feedback that focuses on the evaluation of attitudes; therefore there is a two-way communication but in an imbalanced way in the nature of communication. This model does not use research to find out how stakeholders feel about the organization. Mostly competitive market profit-oriented companies apply that model to compete with other companies. 
4. Two-way symmetric: the purpose is mutual understanding which is used for communication to negotiate with the public. It seeks to resolve conflict and promote mutual benefits, understanding, and respect between the organization and key publics. It conducts formal research as two-way asymmetric, but in this model there is a balanced way in the nature of communication, and message focuses on the evaluation of the understanding of the audience. It is mostly practiced in corporate company in both developed and developing countries.

The developing countries use PR as press agent/publicity and public information in the context of Grunig and Hunt model. The developed countries use two-way asymmetric in the context of the model. The managerial people have a decisionmaking authority to establish a kind of PR in the context and frame it according to the expectations of the organization.

\section{Conclusion}

As a conclusion, the companies in developing countries have to focus on PR which is considered as a backbone of the company. The profit and nonprofit organizations have to understand the importance of PR for their stakeholders' communication process and future survival of the company. The companies have to understand $\mathrm{PR}$ and then create a positive PR professional perception which also affects the overall credibility of the companies' communication planning. The use of PR and PR professionals is valuable for stakeholders and for the society.

\section{Author details}

Anıl Kemal Kaya* and Umut Ayman

Eastern Mediterranean University, Famagusta, Northern Cyprus

*Address all correspondence to: anil.kemal@emu.edu.tr

IntechOpen

(C) 2019 The Author(s). Licensee IntechOpen. This chapter is distributed under the terms of the Creative Commons Attribution License (http://creativecommons.org/licenses/ by/3.0), which permits unrestricted use, distribution, and reproduction in any medium, provided the original work is properly cited. (cc) BY 


\section{References}

[1] Hutton JG. The definition, dimensions, and domain of public relations. Public Relations Review. 1999;25(2):199-214

[2] Smith RD. Strategic Planning for Public Relations. Mahwah, New Jersey London: Lawrence Erlbaum Associates Publishers; 2002. p. 42

[3] Gray JM, Balmer ER. Corporate identity and corporate communications: Creating a competitive advantage. Industrial and Commericial Training. 2000:256

[4] Gray RE, Balmer JM. Corporate identity and corporate communications: Creating a competitive advantage. Industrial and Commercial Training. 2000:260

[5] Gray ER, Balmer JM. Managing corporate image and corporate reputation. Long Range Planning. 1998:696

[6] Theaker A. The Public Relations Handbook. 2nd ed. London: Routledge; 2004

[7] Watson T, Noble P. Evaluating Public Relations: A Best Practice Guide to Public Relations Planning, Research and Evaluation. 2nd ed. London: Kogan Page Publishers; 2007

[8] Grunig JE, Dozier DM, Ehling WP, Grunig L, Repper FC, White J, editors. Excellence in Public Relations and Communication Management. New Jersey: Lawrence Erlbaum Associates; 1992 


\title{
Chapter 3
}

\section{Reputation Management}

\author{
František Pollák, Peter Dorčák and Peter Markovič
}

\begin{abstract}
The problem of building a reputation in the traditional brick-and-mortar world has been known for centuries; we know how to build a good reputation, or more precisely how to help in building a good reputation. Even if we are a target of various half-truths and slanders, we are aware that if they are only spoken words, their durability over time is quickly fleeting. However, written text is different from spoken words; its life durability over time is much longer. In our chapter, we bring the overview of what happens if we must suddenly face the problem of building and maintaining a good reputation in the virtual world of the Internet. Thus, the objective of this chapter is to summarize and present the state of the art in the field of reputation; it consists of the definition of basic terminology and then offers the well-arranged theoretical determination of the problem of reputation in both the traditional brick-and-mortar and virtual world.
\end{abstract}

Keywords: image, trust, reputation, online reputation, Internet

\section{Introduction}

The problem of building and subsequently maintaining a good reputation is hundreds of years old. In the eighteenth century, Benjamin Franklin, a wise man, nowadays mostly known only as the face of the one-hundred-dollar bill, or an inventor of the lightning rod, described the process of building a reputation as an extremely fragile system. He used to say that it takes many good deeds to build a good reputation, but only one bad deed and the good reputation is immediately lost. Today, his words are more up to date than ever before. The rapid onset of massmedia communication in the second half of the twentieth century has fundamentally changed the established principles of corporate practice in many areas. Prior to the advent of the media era, the reputation of business entities, or even individuals, was not only hard to build but also well guarded.

Procedures on how to build a good reputation have been honed for hundreds of years. Years of proven and effective reputation-building tools have almost seamlessly managed to offer solutions in difficult situations. However, times have changed, and the flow of information has accelerated. The nature of information has been adapted to fit the times. What was once private is now public. The availability of information in combination with the interactivity of the environment offers innumerable possibilities for influencing the reputation; of course, it is not just about influencing it in a positive sense. It may seem that the way to achieve a positive result is the effort to maximize transparency, maximum correctness and a positive approach to entrepreneurship [1]. If we lived in an ideal and rational world, it would surely be a guaranteed step toward the desired goal. 
Businesses as well as individuals would be able to plan a sequence of steps to build the dreamed-of target. However, we live in a real world full of real people. Warren Buffett would certainly be able to talk about that. Mr. Buffett came faceto-face with the limits of the real world in 1987, when his company Berkshire Hathaway made its biggest acquisition until that time, buying Solomon Inc. for 9 billion dollars. Despite the famous Oracle of Omaha building up an excellent reputation over dozens of years, it was soon necessary to tangle with an existential threat in the form of negative publicity associated with the activities of Solomon. Mr. Buffett had it easier in the period before the onset of the Internet. The audiences that he and his team had to manage in the process of fixing their reputation were largely clearly defined.

With the advent of the Internet, the flow of information has accelerated tremendously, one could say that a few mouse clicks are enough to destroy a good reputation today. There are many entities who are deliberately attempting to destroy corporate reputation, whether they are fierce competitors or dissatisfied employees or clients. It is enough to mention the name of Jeff Jarvis and his blog Dell Hell from the year 2005. The Internet gives users the ability to permanently interfere with the online reputation of a business in real-time. Google has become the ideal tool to build or destroy a reputation. The unregulated nature of the site provided a platform for the unregulated dissemination of information. The positive side is, of course, the access to up-to-date and uncensored information, while the downside is a severe lack of authenticity and false or modified information. In our chapter, we bring the overview of what happens if we must suddenly face the problem of building and maintaining a good reputation in both, traditional and the virtual world. Sustainable development of corporate reputation has never been that complex.

\section{Definition of basic terms}

In order to be able to describe the changes, which the process of reputation management has undergone from the traditional physical world to the virtual Internet environment, we firstly have to describe and define basic fundamentals of the problem. In the following subchapter, we will define the fundamental concepts of our work, particularly an image, trust, and reputation.

\subsection{Image}

Firstly, it is necessary to define the difference between a corporate identity and image. These two basic concepts are often confused, but their meaning is not the same. There are often mistakes in its understanding and perception, it is usually confused with the corporate design and with the image in general, but as a terminological concept, it is not new [2].

In our opinion, the corporate identity is one of its basic pillars. A company without forming its "self" is soulless, basically it does not exist, it is not able to fully carry out its activities. The corporate identity is an essential part of corporate strategy, and simply said, it represents a way how a company presents itself through individual elements, which then create a single, comprehensive picture of the whole functioning. It represents uniqueness, similar to how every person carries his/her own characteristics and specific features.

It includes a corporate history, philosophy and vision, people who belong to a company, its ethic values, visual style, which is a sort of virtual-real package of all activities of a company. It is a picture of what is a company like or what it wants to 
be, while the image is a public projection of this identity [2]. According to Nový and Surynek [3], the corporate identity means a purposeful formation of strategic concepts of the internal structure, functioning and external presentation of a specific enterprise in the market. The elements, which create it and are a part of it, generally include corporate communication, the abovementioned corporate design and acting.

In literature, there are a countless number of ways of explaining, perceiving, and understanding the word image. We will try to briefly summarize their content. The definition of Image can appear unambiguous and simple. In spite of this assumption, let us look at how this term is understood in the literature.

Kotler [4] understands image as a set of factors, literally a comprehensive complex of impressions, perceptions, opinions, and attitudes of individuals toward the enterprise itself. The American Marketing Association [5] defines image as the customer's perception of products, institutions, organizations, or even individuals that do not necessarily correspond with reality or with the current state. From the point of view of supplementary literature [6], we meet again with considerable illustrative homogeneity. Image is often defined as the way in which the management wants to present the organization externally. As a rule, however, it is not about how the company perceives itself, but rather about how the general public perceives it through its feelings.

Foster [7] notes that image cannot be purchased. An organization has to earn it or deserve it and, of course, that takes some time. It is often perceived by customers as goodwill, trustworthiness coupled with the brand itself. From the nature of the actual definition, it is possible to deduce a considerable degree of non-measurability of this value or assets owned by an enterprise. Image itself then has a relatively high value even despite the fact that the financial statement of this value is complex. Another interesting point of view is the broader approach of perceiving the concept itself, namely the presentation of the knowledge that image is the result of an exchange of views between organizations and individuals, mostly produced through conflicts. Furthermore, we encounter the claim that despite the fact that image passes through development stages whose parts are identifiable, it is essentially composed of simple parts dominant in their details.

Based on the abovementioned definitions, it is possible in our opinion to fully agree with the view of the team of authors Čihovská and Čihovský [8], who make a statement about the complexity of the phenomenon called image, which involves a number of objective as well as subjective factors. The most important factors include factors with a material nature and factors that are predominantly nonmaterial in nature. Non-material factors are represented here by a predominantly intangible presentation of the enterprise to the public (this includes, in particular, the appearance of business representatives on the outside, the style and tools of marketing communication policy and the marketing communication mix, reverse logistics, customer service, the level of written and oral communication level, etc.). Material factors are above all represented by their own level of product quality, the design of these products, the sales premises in terms of their equipment and facilities, the buildings, the design and the facilities of meeting rooms, and last but not least the means of transport used by the company or the clothing of the company's representatives.

All of these views are predominantly universal in terms of space (the brick-andmortar world versus the virtual world represented by the Internet environment). However, we believe that the Internet environment creates a set of specific factors, to some extent, that will be dealt with in the following chapters. Now we can proceed to the other of the supporting areas in the review of theoretical sources, namely the issue of trust and consequently reputation itself. 


\subsection{Trust}

The issue of reputation is closely related to the issue of trust; in the context of literature, these concepts often overlap. There is no doubt that trust determines reputation, but how should we actually define something at first glance as trivial as trust? From the very essence of the concept, the verbal basis-the belief-is obvious right away. In an effort to avoid a theological treatise on faith and thus to remain within the economic and managerial disciplines, we find a rather bizarre definition, namely, the description of trust as a concept linked with the unknown [9].

At first glance, the murky definition surprisingly reveals its point, wherein trust is compared to a bet, in which the specific problem is perceived in the context of balance, among often opposing desires. The process could be likened to a parentchild relationship. If, for example, the child asks the parent about the color of the water, whether the parent's response is trusted by the child is affected by the goodwill of the parent as well as the need for the parent to appear wise in the eyes of their child, even if they do not know the right answer. Specialized dictionaries offer a more detailed definition [10]; they generally state that trust is a kind of reliance on the ability, power, character, or truth of "someone" or "something."

Despite the fact that trust is of a non-material nature, in literature one relatively often encounters the approaches of the indirect measurement of this phenomenon. We choose one [11], the basis of which is the knowledge of the reality we are trying to describe. From the economist's point of view, we come across the concept of "cost," while from a physicist's, the concept of "speed."

How is trust related to these variables? When trust increases, the speed of the implementation of a particular process rises, while the cost of securing this process decreases. In case of bankruptcy, the process is the opposite. In the theory of trust management, it is represented by the belief of the personnel in the organization itself, the belief in achieving the goals of the enterprise. Management believes that the results of their work process management will be beneficial to the organization's personnel. Personnel and management sharing knowledge believe that management will appreciate this behavior positively. They expect that their behavior to increase group performance will be properly rewarded [12].

Trust can also be called a force that can bring individuals together into groups, creating a homogeneous society from an environment full of confusion and anarchy [13]. Also, as a state of mind, an expectation of one business partner to another, behavior, or a response of a predictable and mutually acceptable nature [14].

Different authors offer different interpretations [15]; trust means much more than just relying on the "other" side. Trust can come from goodwill, a common interest, but force can also be used to achieve it. It takes place under different conditions; it covers various areas of public and private life and includes a wide range of activities. In the context of the definition of the term, we again return to the concept that presents trust as a sort of a bet. The concept includes the notion of risk [9], a factor that entities usually attempt to avoid in all circumstances. The concept of risk in itself already indicates a state of a possible threat or a possible loss. However, the benefits of trust between entities often have a higher value in the long run than the potential losses. The bet "on trust" therefore expresses a certain degree of probability with which one entity determines that another entity or group of entities will perform a certain action or reaction [16].

Without trust, we would hardly know how to ensure any cooperation. Enterprises or even doing business itself would be almost impossible without the presumption of elementary trust. In literature [17], we often encounter the claim that trust is an oriented relationship between two subjects engaging in mutual interaction. In this case, orientation is an expression of the relationship of the 
subjects in terms of their resources and objectives. In this way, we come to describe two basic types of trust, contextually independent (trust in this case is given by the subjective probability of the expected action) and contextually dependent (trust is determined in this case by the extent of dependence on relative safety, despite the risk of negative consequences). In practical terms, these states could be described through two simple statements:

- We trust you based on your good reputation,

- We trust you despite your bad reputation.

The first of the arguments illustrates the situation where the trust of the subjects is determined by the reputation of one of the parties. The second of the statements illustrates the situation where, despite the existence of a negative reputation, there is "some" knowledge, for example, based on direct experience; this will subsequently change the weight of the negative assumptions.

Several authors discuss the classification of models based on trust and reputation, the basic criterion for classification is the typology of models. According Sabater and Sierra [18], interpretation is as follows: does the model work with reputation, confidence, or both parameters at the same time? Through simple decomposition, we get three basic categories, namely:

- Models based solely on trust - they only work with a factor of trust,

- Models based solely on reputation-they only work with the factor of reputation,

- Hybrid models_-using both of these parameters.

Based on the origin of the information, when classifying models, we consider parameters such as origin and source of information, authenticity, irrational factors (e.g., prejudices or ignorance of the social roles of subjects), and the like. Through the theoretical development of the issue of trust and consequently its relation to the reputation issue, we can proceed with the definition of reputation itself.

\subsection{Reputation}

In terms of reputation, the literature offers a wide range of views, from interpretational formalized views to views of an almost informal nature. In general, all of these views agree that reputation as a business asset is an extremely fragile element. At the same time, we are confronted with the claim that reputation is an element that every organization has to offer without distinction [19].

Unlike trust, often described as an oriented state, reputation is a more complex term, but we also encounter the claim (in our opinion not quite accurate) that it can be seen as a synonym for trust and reputation. Let us look at how reputation is defined within the scope of the available literature. Reputation is perceived as the overall quality, the optics, how the organization is perceived or judged by individuals [20].

The definition is a fairly simple interpretation; on the other hand, the purely formal encyclopedic definition [21] deals with reputation, again as a general quality; this time, however, it extends this quality to the very nature of the organization, which is clear and known to the target audience, with emphasis being placed on how these audiences perceive the attitudes, actions, and opinions of the organization. 
From the point of view of corporate management, it can be argued that, in the past, reputation was the domain of marketing, while currently it is integrated into the company strategy itself [22]. An interesting management view of the issue of reputation is the claim [23] that reputation can also affect activities directly unrelated to the fulfillment of corporate goals. It may be informal expressions of personnel, insufficient, or unsatisfactory responses to customer complaints, or illconsidered statements of representatives of organizations for the media. From the point of view of history [22], it is possible to believe that reputation or reputation management evolved from public relations.

As mentioned above, reputation is considered by many authors to be an asset of an organization. We also encounter the claim that it is the most comprehensive business asset [24]. Despite the challenge in the form of organized corporate reputation management and the use of comprehensive measurement approaches, reputation is still a relatively unexplored area.

After defining the term, we will come to the decomposition of the issue from the point of view of its partial attributes, namely, we will focus on components of reputation. Based on professional literature, reputation can be seen in three dimensions [25]:

- Primary dimension: reputation is created based on the organization's personal contacts and its target audiences. Such a reputation has an immediate and personal character. From a psychological point of view, we encounter an increased possibility of occurrence of the phenomenon of the first contact. With this first contact, target groups only perceive the organization's distinctive attributes and form their initial attitudes based on these attributes.

- Secondary dimension-also called indirect reputation in the literature: such a reputation, unlike the previous dimension, does not have a direct personal nature. It is formed through the sharing of messages through media or reference groups. Because of the impersonal and mediated nature of the messages, we encounter an increased incidence of prejudices and stereotypes within this dimension. These animosities often have a negative impact on the formation of reputation as they create the premise for superficial judgment.

- Cyclical dimension - also referred to as the third way: it is an approach within which organizations adapt the character and nature of communication to the perceptions of their target audiences. As far as positive attitudes are concerned, organizations typically do not need to correct the form and content of shared messages. If negative attitudes are noted, organizations will operatively change, or adapt their communication, behavior, or even products.

Harris and Fombrun [26] considered a reputation as collective evaluation of the company's ability to provide a valuable product, service, or another value to a group of customers. They developed the scale for measuring the corporate reputation, which they called the corporate reputation quotient (RQ). The reputation quotient is a complex method of measuring the corporate reputation. The given scale [25] consists of six criteria, about which we can ask the following questions:

1. Emotional appeal: is the company popular? Is it admired and respected?

2. Products and services: what is the quality of products and services of the company? Is the company active in innovations and credible? 
3. Financial representation: how can we evaluate the growth opportunities and risk of the company? Does it stand on a sound financial basis?

4. Vision and leadership: is there a strong leadership in the company? What visions do the leaders follow? Is it able to recognize opportunities and threats in the market?

5. Working environment: how successfully is the company led and what is the quality of co-workers?

6. Social responsibility: how significant is the social engagement of the company and how responsibly does it behave toward its environment?

The stated criteria are the results of work of Harris and Fombrun, who cooperated on the creation of a standardized tool that could be used to measure the perception of reputation of various companies in all sectors with more segments with multiple stakeholders. They found 20 attributes by the extensive analysis, which they subsequently grouped into the already mentioned six dimensions or criteria [27]. The work related to the corporate reputation was assigned especially to the area of marketing and communication. Burke et al. [28] state that the corporate reputation is nowadays integrated also into human resources management and especially to the corporate strategy. A reputation is mediated to the public by managers of an organization. It is generally recognized, that a reputation starts from inside to outside [29]. Fombrun and Foss [27] noted that an organization is doing well if it takes care about its own reputation, and they based the following factors on this emphasis:

1. the principle of characteristic signs-a strong reputation is the result of a significant position of the company in the minds of customers,

2. the principle of focus-companies can contribute to a strong reputation if they focus on their activities and communication around one central topic,

3. the principle of strength-a strong reputation is the result of company's consistency in its activities and communication with the internal as well as external environment,

4. the principle of identity-a strong reputation is the result when companies act in a way that is in accordance with the principle of identity. The main task for a company is to be perceived real by its customers and the public,

5. the principle of transparency-a strong reputation is the result when companies are transparent in managing their own affairs. The main aim for companies is to be perceived as open and honest in their business activity. Transparency requires good communication, a lot of good communication.

A company can be differentiated from its competitors through the corporate reputation. The reputation gives a significant advantage in industries with intangible assets such as innovations, creativity, intellectual capital, and the high level of customer services [28].

From the stated theoretical overview, it is possible to extract the essence of reputation management, namely four fundamental determinants of reputation management, comprised of responsibility, trustworthiness, reliability, and credibility. Each of these issues has a significant and irreplaceable role in the reputation management process. 


\section{Reputation management}

After defining concepts in previous subchapters, it is possible to conceptually define the key issue; thus, in the logical continuity of our text, we may start to focus on the theoretical determination of the problem of reputation in both the traditional brick-and-mortar and virtual world, as well as selected methodologies of measuring this phenomenon.

\subsection{Reputation from the perspective of traditional world}

The importance of corporate reputation as such is growing steadily, especially in light of the current competitive business environment. Correctly set reputation strategy can contribute to the overall prosperity of the business and influence its market value. There are a lot of strategies on how to build and coordinate reputation; however, it is important to realize that success needs more than just good technology or quality product/service portfolio.

The involvement of corporate reputation studies in multiple disciplines has caused it to have numerous definitions [32]. Fombrun and Van Riel define business reputation as a value that differentiates the company from others, is linked with strategic measures and activities, and is difficult to imitate [30]. When defining business reputation, authors frequently mention common denominators such as trust and cooperation. Van Riel representative of Reputation Institute further defines business reputation as a set of consumers' perceptions of company's past actions, results, expectation of further actions, and anticipations [31]. According to the American Heritage Dictionary, reputation is opinion of interested parties on the company [32].

Moreover, reputation also expresses credibility in relation to consumers and the overall increase in market value since it influences the market position of the company by focusing on decision-making process [33]. The basis for reputation building is the perception of external observers-consumers. In addition, Fombrun and Van Riel also suggest that being reliable and trustworthy in the eyes of consumers is crucial for reputation building [30]. With regard to consumer perceptions, Budd notes that it is very difficult to change the perception of a brand, despite the fact that it is moldable [34]. The fact that businesses literally fight for their reputation as its effect can change attitudes of consumers is studied by numerous authors $[1,31,35,36]$. Good reputation can increase customers' confidence in their purchasing decision and reduce shopping dissonance, thus leading to increased satisfaction and customer loyalty [24].

The Reputation Institute has defined a set of seven major factors affecting business reputation: Products, Innovation, Workplace, Governance, Citizenship, Leadership, and Performance, in which [36]:

- Leadership means how company is leading the way.

- Performance and profitability are key indicators of reputation success.

- Consistent delivery of quality products and services determines a company's value.

- Innovative companies that creatively push the status quo are more highly regarded.

- Workplace: corporate, culture directly impacts recruitment, retainment, and the quality, ability and willingness of greatest asset-human resources. 
- Governance: only with stakeholder support from those providing company a license-to-operate and benefit-of-the-doubt will result in continued growth.

- Citizenship: corporate social responsibility, charitable giving, volunteer efforts, and philanthropic campaigns help to make the world a little better.

Based on a series of research into reputation, Reputation Institute states that the abovementioned seven factors have different weights or pyramid-like importance factors, the basis of which is the quality of the goods or services and the associated customer service, followed closely by the integrity of the company (fulfillment of declared promises and ethical behavior), and then all other attributes [31].

In other words, what matters most is a portfolio of products and services; however, commercial variables are not sufficient enough to achieve a good business reputation. Research such as this creates a knowledge base for deeper exploration of issues in different environments. So, let us look at the issue of reputation in the Internet environment.

\subsection{Reputation from the perspective of the Internet}

As mentioned in the introduction to the paper, innovative technologies have fundamentally changed the established principles of corporate practice in many areas $[37,38]$. Prior to the arrival of the Internet, the reputation of business entities, or even individuals, was hard to dig up, but also well guarded. Years of proven and effective reputation-building tools have almost seamlessly managed to offer solutions in difficult situations.

But times have changed, the flow of information has accelerated, and the nature of the information has been adapted to fit the time. As we have already mentioned, what was once private, is public today.

The availability of information in combination with the interactivity of the environment offers innumerable possibilities for influencing reputation; of course, it is not just about influencing it in a positive sense [39]. Proven approaches have lost their effectiveness, in our opinion it was largely due to the use of "analog" tools in the "digital" environment. The incompatibility of traditional approaches derived from the brick-and-mortar environment was particularly pronounced at the turn of the 1990s and 2000s when solving the problems created in the virtual environment of the Internet, and subsequently (and more particularly) at the end of the first decade of the twenty-first century [40, 41]. We mention just one for all of the examples, Dell Hell, a blog of a dissatisfied customer of the technology giant Dell, which has resulted in a series of unpleasant events resulting in not an insignificant decrease in the value of the shares and thus the overall market capitalization of one of the largest players in the field of information technology.

But, let us go back to the very essence of the concept of corporate reputation from the perspective of the Internet also named as online reputation, often referred to as online reputation or virtual reputation. It is nothing other than reputational issues in the Internet environment; at the same time, we could also call this statement the simplest definition of the term.

The fact that it concerns a neologism from the point of view of terminology also suggests a rather austere interpretation of the concept of business vocabulary [42], which describes this term as obscure without a specific definition referring to the individual, society, or industry.

Many authors [43-45] describe online reputation as the overall presence of a particular subject on the Internet. At present, from a layman's point of view, presence on the Internet is equal to presence on social media, and from a professional point 
of view, this view is to a large extent limited. Reputation is not only the domain of social platforms, it is created primarily by users sharing their attitudes and following their interactions through a wide range of tools [46] such as search engines, catalogs, forums, blogs, and so on. Due to the instrumental variety of marketing in the Internet environment, it is recommended that the subjects use the largest possible number of these sub-tools as part of their marketing communications.

There is pressure on active marketing communication to eliminate potential threats caused by content moderation or the complete passivity of the subject. The contrast of "one" negative mention in the context of dozens of positive messages will greatly reduce the risk of a long-term damage to the reputation of the subject. Another author [47] notes that the concept of online reputation covers a wide range of aspects of the business presentation in the Internet environment. Online reputation is therefore a direct consequence of the enterprise's action on the Internet. It includes not only the actual performance of the company, but also the interaction of the company with potential as well as actual customers. Submitting a question about the importance of online reputation for business itself has long been inappropriate. It is more than desirable for businesses to actively manage their virtual reputation without delay. The author also presents three essential points in which he unambiguously and clearly describes the circumstances underlying the need to actively seek to manage corporate reputation on the Internet environment, namely:

- the continuous increase of Internet users, the perception of the advantages of the Internet in the process of making decisions about purchasing or purchase itself by users,

- perceptions of the Internet, as a sort of "lightning rod" of business activities, a high degree of secondary transparency,

- the need to not lose control of your own brand.

The very structure of the Internet multiplies the effort necessary for the active management of a company's reputation. Technologies with user-driven content of a varying nature, caused by various motivators, are not able to "judge" this content themselves. From the viewpoint of the tools, these are simple data, numerical series of ones and zeros.

The technology itself distinguishes the character of the message, distinguishes true information from false, and separates private information from public. Based on its principle, technology is already beyond generally accepted moral principles; the cool logic of machine code allows users to disclose whatever they deem appropriate [48]. Once a message is published, it is generally accessible via the Internet without geographical or time limitations. Enterprises must be aware of the fact that any interaction between them and the users is public and official at every turn, so it is necessary to approach it with the appropriate weight. Otherwise, the effort spent to remedy the undesirable situation may be highly counterproductive [49]. It is possible to conclude that the Internet has radically affected the dynamics of corporate reputation management.

With the growing consumer and media focus, businesses are finding it increasingly difficult to reach target markets in a way that generates the desired interactions. In a decentralized Internet environment, the voice of an individual can be the power of a large organization, the user is given the opportunity to present his/her opinions or attitudes. At any time, they can present their attitudes in the form of reviews, blogs, discussion posts, and so on, from the position of a "journalist" of "their own media." They thus have the ability to judge the brand or the company itself. 
New communication channels have greatly affected the balance of power. As a result, the reputation of businesses is often no longer defined by their behavior and performance, but by how they are perceived by the Internet community and its reactions and interactions toward the organization. Classical approaches to public relations are far too inefficient in the Internet environment as well as top-down communication [50].

\subsubsection{Online reputation management}

As we mentioned in one of our previous studies [61], the increasing number of Internet users and the related increase in users of social networks, blogs, and websites where the content is generated by the users themselves now justify the growing importance of Internet monitoring. For this purpose, entities can use a variety of tools that continuously index new pages on the Internet and compare them with the monitored phrases such as product name, company, competitors, or any other keyword.

Literature discusses the issue only marginally, but from the point of view of corporate practice, we encounter a relevant and highly current level of development as such. Practitioners [51] define the term "online reputation management" simply "ORM" as a process of managing user perception on the Internet, or as a systematic monitoring of corporate reputation in as wide a range of online media as possible, and potentially influencing this reputation in the positive direction [52].

The goal of ORM is therefore to actively prevent damage to the image of an enterprise in the Internet environment. In the literature, one can also meet the term "Reputation Management in the Search Engine Environment," which includes active Internet monitoring through dominant search engines such as Google, communication with target audiences, evaluation and interpretation of monitoring results, crisis management, reputation management, and crisis communication.

Many enterprises still do not know how to effectively build their online reputation. Online reputation management offers an effective tool to deal with a number of business-related activities in a turbulent, often unclear, social networking environment, portals, search engines, and opinion-forming media. The ever-increasing number of Internet users is logically reflected in the continuous year-on-year growth of social network users, discussion forums, website and portal visitors, blog readers, bloggers themselves, and audio-visual content contributors.

With the growth of these user groups, the need, importance, and justification of monitoring this virtual mass media are growing. Internet monitoring does not necessarily mean hours spent in front of the monitor; there is a wide variety of automated tools to index sites, their comparison with monitored phrases in the form of product names, companies, or any relevant context in the form of keywords [51].

At the conclusion of this chapter, as well as the whole theoretical discourse, it is necessary to be aware of the key facts based on empiricism and the continuous study of online reputation management by one of the most current authors [53]:

- ORM is not a one-time activity that needs to be done from time to time, it is a continuous and never-ending process.

- Since an honest attitude is the best approach, justification is the best response to legitimate customer reservations about the products offered by the company.

- The processes of the brick-and-mortar world, although in the virtual world, may not produce the desired results; of course, that does not mean that the brick-and-mortar world can be neglected in the virtual reputation management process. 
- Recognition of errors is appropriate as it is impossible to hide them in a virtual environment. Concealing or denying reality is a direct way to inevitably damage reputation.

- Ignoring negative reactions is dangerous, deleting reactions is unacceptable.

\subsection{Selected methodologies of measuring reputation in online environment}

To provide a complete view of the issue, it is necessary to summarize available methodologies of measuring this phenomenon. In the following subchapter, we present knowledge about the selected systems of measuring online reputation.

\subsubsection{Reputation mechanisms}

Before we will fully dedicate to the systems of creation of reputation, it is necessary to state the criteria, which are presented by Wang and Vassileva [54]. The stated criteria are a part of reputation systems:

1. centralized versus decentralized-whether the reputation systems are centralized or decentralized, they determine the feasibility and complexity of reputation mechanism. In the centralized system, the central node accepts all responsibility for the management of reputation of all members. In the decentralized system, there is no central node. Members of the system must cooperate and share responsibility for the management of reputation. Generally speaking, the mechanisms in the centralized systems are less complex and easier for implementation in the decentralized systems. Nevertheless, they still need strong and reliable central servers and large bandwidth for calculation, data storage, and communication,

2. person/agent versus resources—reputation systems may be classified by people/agents or resources. In the system of people/agents, the emphasis is put on the building of reputation through people and their acting on behalf of other people. In the system of resources, we focus on the modeling of reputation through resources, which could be products or services,

3. global versus personal-in the global reputation systems, the reputation of people/agents/products/services is based on opinions of the general population, which are public and visible for all members of the system. While in the personal reputation systems, the reputation of people/agents/products/ services is based on the opinion of a group of individual people, which may be different in the eyes of various members and they are influenced by many factors such as members of various social networks or uncertainty of the environment. It is much more difficult to create a global reputation mechanism in the decentralized system than in the centralized system.

\subsubsection{Systems based on counting and averaging}

If we talk about the reputation systems, the easiest solution is to count all positive and negative evaluations. The overall result related to a certain user is the difference between all positive and negative evaluations. The given principle is used mainly on the server eBay, which is one of the largest online markets and a community with more than 50 million registered users. After every transaction, a seller or buyer can give each other positive, negative, or neutral ratings, which add them 
plus or minus points in the reputation $(1,-1,0)$. Users can also leave comments. Especially, when people give negative evaluation, they definitely leave a comment that explains it.

Despite the fact that the reputation mechanism on eBay is very simple, empirical results show that it supports transactions between sellers and buyers. It is caused mainly by the fact that in case of sellers with a better reputation it is more probable that they will sell more. This mechanism can also prevent the conspiracy of people to artificially increase their reputation for each other [55].

\subsubsection{ReGreT model}

Another important model of the reputation quantification is the ReGreT model, presented by Sabater and Sierra [18]. The ReGreT model is a standard system of trust and reputation, focused on the complex small and middle-sized e-commerce environment, where social relationships between individuals play an important role. The system takes into consideration three different sources of information, which are direct experience, information from third parties and social structures. The ReGreT model of reputation is based on three specialized types of reputation:

1. Attested reputation-is calculated from information coming from witnesses,

2. Reputation surroundings-in which a reputation is calculated by information gained based on social relationships between partners,

3. System reputation-it is a value of reputation based on roles and general properties.

Another element of this system is the ontological structure. The authors believe that a reputation and trust are not separate and abstract concepts, but rather versatile aspects. The ontological structure provides necessary information for the combination of values of a reputation and trust, in order to make the calculation and combination from more complex attributes.

\subsubsection{Sentiment analysis}

Sentiment analysis (or opinion mining) can be defined as the automatic quantification of subjective content expressed in the text form with the aim to determine attitudes of a commentator or writer in respect of a given subject. It belongs to one of the oldest and often used methods of measuring reputation. We can generally say that the sentiment analysis is aimed at the determination of attitude of a speaker or writer with focus on a certain topic or overall conceptual polarity of a document. The attitude may be a judgment or evaluation of a particular person, emotional state of the author, or intended emotional communication (it represents an emotional effect, which an author wishes to create toward a recipient) [56]. It has a wide range of application areas such as services, film industry, consumer goods, measurability of the impact of online evaluations, monitoring of social media, monitoring of evaluation of products, services or brands, forecast of stock price development based on online evaluations, identification of cyberbullying, etc. Its priority tasks include identification of subjectivity, orientation, power and sentiment carrier, classification of emotions, detection of sarcasm, or various comparisons [57].

The sequence of the reputation measuring process starts by defining a representative of the investigated segment and its competitors in the industry. Within the sentiment analysis, there are 10 first results in the search engine taken into consideration. 
By the end of this section, we will continue with the holistically presented most important findings of the complex research. Based on our findings, there are presented conclusions and postulated recommendations for science and practice.

\subsection{Sustainable development of reputation management}

The issue of managing reputation especially online reputation as a new phenomenon in the form of fragile intangible assets is gradually gaining on importance and it is becoming one of the essential prerequisites for responsible and sustainable reputation management. Selected methods of quantification and subsequent measurement of reputation were used, for the purposes of the presentation of the issue. Based on many years of our intensive research into the issue of reputation, we can conclude that sustainable development of reputation management combines offline and online techniques, as both worlds are connected.

For better explanation of linking findings and proposed model, we will use an example from one of our recent studies [58]. Using the multi-factor analysis of reputation [59], which combines the best approaches presented in the previous subchapter, we tested specific subjects, namely 15 best Adriatic Coast Hotels selected by experts of The Daily Telegraph. Within the testing, we considered the entire spectrum of perceiving their reputation since we compared the whole specter of relevant virtual factors and connections measured by us against significant and relevant ranking of the mortar world provided by British experts for The Daily Telegraph. From the point of view of the subjects, these subjects as a lighthouse of perceived quality guarantee the relevance for identified connections, and findings, and recommendations drawn from them directed to the other players operating in the analyzed market. The analysis showed relatively close relations between offline and online factors. There is connection. Strong connection between ratings indicate necessity of combine online and offline approaches to obtain sustainable development of reputation of tested subjects.

Based on the findings, we have established a model of sustainable development of corporate reputation; this model looks as in Figure 1.

From the point of view of the sustainable reputation management, the subjects from the top places of the search engine results have undoubtedly a notable advantage from the point of view of online reputation for general public. If a user is searching for relevant information and at the same time does not have his/her own experience with a particular subject, in the absence of strong and positive presence,

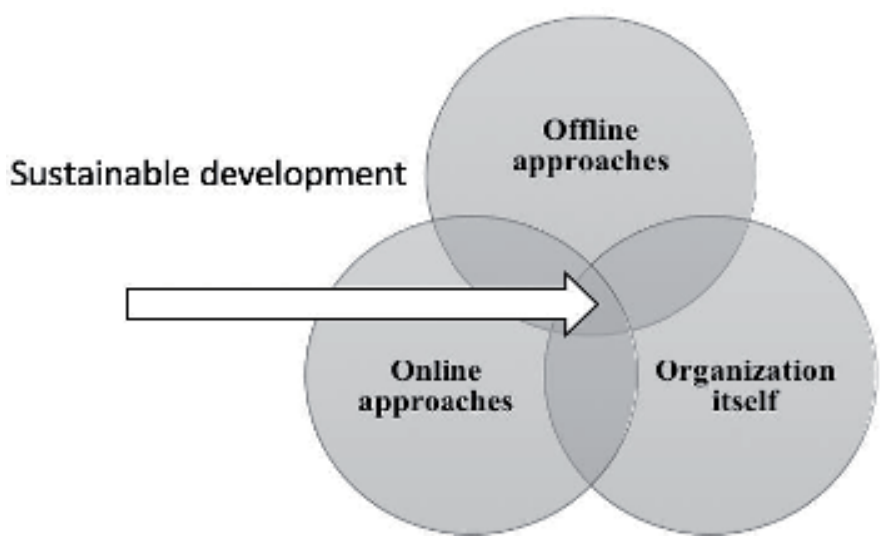

Figure 1.

Model for sustainable development [58]. 
his/her perceptions of the particular subject can be significantly deformed despite the enormous endeavor and physical demonstration of the perfection of the subject in the traditional world.

By eliminating negative publicity while maximizing positive media outputs in opinion-forming Internet media, and the displacement of neutral or negative search results to irrelevant positions presented by the second to $n$-th side of Google search results. Responsible and sustainable is the multiplatform approach to the online reputation management. Strategic alliances of major players will help more effective optimization of search engines, improving the availability of preferred results on relevant positions in searching. However, Google is not the only platform that needs to be considered. Integration of the main platforms presented by virtual social networks and media will ensure active feedback, as well as active content control. This largely eliminates the possibility of spreading half-truths and incomplete or untrue information. Involving virtual social networks in communication portfolio of companies can significantly contribute to the increase of interactivity and authenticity within communication provider-consumer. Not speaking about invaluable source of relevant data in the form of feedback in the real time. Especially in crisis marketing communication [52], the integration of modern communication channels is seen as key to master the so-called first wave. Finally, it is important to pay attention to the construction of consumer tribes; without any developed and motivated user base, it is not possible to predict any significant results for any of the activities described.

Even though different environments required specific approaches, recorded different dynamics, and required specific tools, the network between them is very strong $[39,58,60]$. It is almost impossible to be a star only in one world. However, by its nature, online reputation is more fragile.

\section{Conclusions}

The traditional world in our chapter, also referred to as the offline environment, has a dominant role in the process of building the reputation of the subjects as such. Renowned institutions focusing on the evaluation of different target groups developed effective approaches to measure reputation bound to objective data and objective factors, such as demonstrable outputs, technologies, certifications, and so on. On the other hand, factors affecting reputation in the virtual world are predominantly subjective. Therefore, a gap between objective and subjective reality occurs. The problem of objective reality is that it requires enormous resources in the form of finances, time, effort, and so on. Subjective reality, on the other hand, is based on the opinions of anonymous individuals. This results in the immense fragility of reputation as an intangible asset, as on one side, there is a tremendous effort, and on the other side, a disproportionate variability and uncertainty. We share the opinion of the authors [46] who consider the effort not to give up the control over the brand as one of the key preconditions when moving from offline to online reputation management. Sustainability in terms of building a corporate reputation is, in our opinion, continuation of investing in a traditional environment while actively monitoring the virtual environment. As we present in the proposed model, only by considering all variables, the organization can minimize threats and maximize opportunities on the increasingly turbulent twenty-first century market.

Our chapter synthesizes all mentioned points of view, offers a clear definition of basic terminology as well as well-arranged theoretical determination of the problem of reputation in both the traditional brick-and-mortar and virtual world.

The presented results of own research, especially after their visualization, bring interesting findings worthy of consideration. Despite the fact that literature offers a 
wide range of approaches to exploring the issue of reputation, the presented chapter offers a relatively simple and fairly accurate form for understanding the basic principles of active reputation management, thus providing an effective tool for increasing the competitiveness for a wide range of subjects trying to seek strategic alliances to achieve sustainable development of their reputation and maximize their market advantages against their competitors.

\section{Acknowledgements}

This chapter is one of the outputs from the research grant project KEGA no. 025EU-4/2017. This chapter is one of the outputs from the research grant project VEGA no. 1/0066/17.

\section{Conflict of interest}

The authors declare no conflict of interest.

\section{Author details}

František Pollák ${ }^{1 *}$, Peter Dorčák ${ }^{2}$ and Peter Markovič ${ }^{2}$

1 Faculty of Management, University of Prešov, Prešov, Slovakia

2 Faculty of Business Management, University of Economics in Bratislava, Bratislava, Slovakia

*Address all correspondence to: frantisek.pollak@unipo.sk

\section{IntechOpen}

(C) 2019 The Author(s). Licensee IntechOpen. This chapter is distributed under the terms of the Creative Commons Attribution License (http://creativecommons.org/licenses/ by/3.0), which permits unrestricted use, distribution, and reproduction in any medium, provided the original work is properly cited. (cc) BY 


\section{References}

[1] Williams RJ, Schanke ME, Fredenberger W. The impact of corporate strategy on a Firm's reputation. Corporate Reputation Review. 2005;8(3):187-197

[2] Vysekalová J, Mikeš J. Image a firemní identita. 1. Vyd. Praha: Grada Publishing a.s.; 2009. p. 192. ISBN: 978-80-247-2790-5

[3] Nový I, Surynek A, et al. Sociologie pro ekonomy a manažery, In: Grada Publishing. E-reading [Internet]. 2008. Available from: http://www.ereading.cz/ nakladatele/data/ebooks/5621_preview. pdf [Accessed on: 18 January 2014]

[4] Kotler P. Marketing Management. Prague: Grada Publishing; 1998. ISBN 80-7169-600-5

[5] AMA. Dictionary [Internet]. 2017. Available from: https://www.ama. org/resources/Pages/Dictionary. aspx?dLetter=I [Accessed on: 06 January 2017]

[6] Fillis I. Image, Reputation and Identity Issues in the Arts and Crafts Organizations [Internet]. 2008. Available from: https://www.researchgate.net/ profile/Ian_Fillis/publication/233519408_ Image_Reputation_and_Identity_Issues_ in_the_Arts_and_Crafts_Organization/ links/544a27e70cf2ea6541343de9.pdf [Accessed on: 28 January 2016]

[7] Foster R. Jak získat a udržet zákazníka. Brno: Computer Press; 2002. p. 117. ISBN 80-7226-663-2

[8] Čihovská V, Čihovský M. Európsky marketing. Bratislava: Sprint dva; 2011. p. 204. ISBN 978-80-89393-36-7

[9] Desteno D. Pravda o dôvere. Bratislava: Citadella; 2014. ISBN 978-80-89628-42-1

[10] Nixon P, Terzis S. Trust management. In: First International Conference, ITrust 2003. Heraklion: Springer
Science and Business Media; 2003. ISBN 978-354-04-02-244

[11] Covey S, Merrill R. Důvěra: jediná věc, která dokáže změnit vše. Prague: Management Press; 2008. p. 347. ISBN 978-80-7261-176-8

[12] Kim WC, Mauborgne RA.

Procedural justice, attitudes, and subsidiary top management compliance with Multinationals corporate strategic decisions. Academy of Management Journal. 1997;36(3):502-526

[13] Luknič AS. Štvrtý rozmer podnikania - etika. Bratislava: SAP; 1994 ISBN 80-85665-30-1

[14] Hittmar Š et al. Knowledge Base for Management - Theory and Practice.

Žilina: University of Žilina; 2010. p. 334. ISBN 978-80-554-0296-3

[15] Grudzowski WM et al. Trust Management in Virtual Work Environments: A Human Factors Perspective. Boca Raton, Florida: CRC Press; 2008 ISBN 978-142-006-894-8

[16] Gambetta D. Can we trust trust? [Internet]. 2000. Available from: http:// citeseerx.ist.psu.edu/viewdoc/downloa d?doi=10.1.1.24.5695\&rep=rep1\&type= pdf [Accessed on: 09 February 2014]

[17] JØsang et al. Survey of trust and reputation systems for on-line service provision [Internet]. 2007. Available from: http://eprints.qut.edu.au/7280/1/7280.pdf [Accessed on: 09 February 2014]

[18] Sabater J, Sierra C. Review on computational trust and reputation models [Internet]. Available from: http:// www.iiia.csic.es/ sierra/articles/2005/ SabaterSierra.pdf [Accessed on: 09 February 2014]

[19] Marsden H. Guard Your Reputation On-line. Birmingham: Smartebookshop; 2013 
[20] Griffin A. New Strategies for Reputation Management: Gaining Control of Issues, Crises \& Corporate Social Responsibility. London: Kogan Page Publishers; 2008

[21] Brittanica. [Internet]. Available from: https://www.britannica.com [Accessed on: 01 June 2016]

[22] Cooper C et al. Corporate Reputation: Managing Opportunities and Threats. London: Gower Publishing; 2012. ISBN 978-14-09460-39-8

[23] Benedigová M. Reputáciu firmy nemožno ponechat' len na PR manažéra [Internet]. 2003. Available from: http:// www.etrend.sk/podnikanie/reputaciufirmy-nemozno-ponechat-len-napr-manazera.html [Accessed on: 26 January 2016]

[24] Lafferty B, Goldsmith R. Corporate credibility's role in consumers' attitudes and purchase intentions when a high versus a low credibility endorser is used in the add. Journal of Business Research. 1999;44:109

[25] Svoboda I. Public relations - moderně a účinně. Prague: Grada Publishing; 2009. ISBN 978-80-24728-66-7

[26] Walsh G, Beatty S. Customer-based corporate reputation of a service firm: scale development and validation. Journal of the Academy of Marketing Science. 2007;35(1):127-143. ISSN 0092-0703

[27] Fombrun C J, Foss C B. The reputation quotient, Part 1: Developing a reputation quotient. [Internet]. 2001. Available from: http://www. reputationinstitute.com/frames/ press/01_15_14_GUAGE.pdf [Accessed on: 09 February 2014]

[28] Burke JR, Graeme M, Cooper LC. Corporate Reputation: Managing Opportunities and Threats. London: Gower Publishing; 2012. p. 356 ISBN 1409460398
[29] Zayed AM. Does corporate reputation affect brand preference? Application to the soft drinks industry in Egypt. African Journal of Marketing Management. 2015;7(1):7-15

[30] Fomburn CJ, Van Riel B. How Successful Companies Build Winning Reputations. New Jersey: FT Press; 2004. ISBN 978-0137-144-41-9

[31] Van Riel B. How to Measure the Success of Your Corporate Communication Department: Reputation Benchmarks: Insights from Reputation Institute [Internet]. 2018. Available from: https://www.reputationinstitute.com [Accessed on: 16 February 2018]

[32] Ozturk Y et al. The art of corporate reputation management in accommodation businesses. Journal of Travel and Tourism Research. 2013;13(1/2):71-90

[33] Dentchev NA, Heene AA. Managing the Reputation of Restructuring Corporations: Seng the right signal to the right stakeholder. Journal of Public Affairs. 2004;4(1):56-72

[34] Budd JF. How to manage corporate reputations. Public Relations. 1994;39(4):11-15

[35] Tavakolifard M. On Some Challenges for On-line Trust and Reputation Systems [Internet]. 2012. Available from: http://www.diva-portal.org/smash/get/ diva2:548911/FULLTEXT02 [Accessed on: 23 February 2018]

[36] Van Riel B. Reputation Institute: How can corporate reputation be measured? [Internet]. 2014. Available from: http://www.reputationhouse. co.za/how-can-corporate-reputationbe-measured/ [Accessed on: 22 April 2018]

[37] Delina R. Transparency in electronic business negotiations-evidence based analysis. Quality Innovation Prosperity. 2014;18(2):79-89 
[38] Delina R, Drab R. Socio-economic aspects of trust building for the electronic business platforms. E\&M Economics and Management. 2010;13(4):110-122

[39] Pollák F. On-line reputačný manažment $\mathrm{v}$ podmienkach stredoeurópskeho virtuálneho trhu. Prešov: Bookman; 2015

[40] Siano A. et al. Exploring the role of on-line consumer empowerment in reputation building: research questions and hypotheses [Internet]. 2011. Available from: http://www.academia.edu/1096337/ Exploring_the_role_of_on-line_ consumer_empowerment_in_reputation_ building_Research_questions_and_ hypotheses [Accessed: 22 March 2018]

[41] Soviar J. Simplification of marketing scheme for business startups. Communications Scientific Letters of the University of Žilina. 2011;13:55-57

[42] Businessdictionary. Reputation management [Internet]. 2015. Available from: http://www.businessdictionary. com/definition/reputation-management. html [Accessed: 15 February 2017]

[43] Janouch V. 333 tipů a triků pro internetový marketing. Brno: Computer Press; 2011

[44] Jones B, Temperley YJ, Lima A. Corporate reputation in the era of Web 2.0: The case of Primark. Journal of Marketing Management. 2009;25(9):927-939. ISSN 0267-257X

[45] Loayza J: The Beginner's Guide to Reputation Management: 8 Core Principles of Reputation Management [Internet]. 2013. Available from: http://reputationhacks.com/guideto-reputation-management-3-8-coreprinciples [Accessed on: 23 March 2018]

[46] Weber L. Marketing to the Social Web: How Digital Customer Communities Build Your Business. John
Wiley \&. Sons: Hoboken; 2007. ISBN: 978-0-470-41097-4

[47] Kanika D. Prečo je online reputácia dôležitá? [Internet]. 2016. Available from: http://www.pranswer.com/sk/ manazment-povesti-referencie-arecenzie/preco-je-online-reputaciadolezita/ [Accessed on: 07 April 2016]

[48] Fertik M, Thompson D. Wild West 2.0: How to Protect and Restore Your Reputation on the Untamed Socide Frontier. New York: Amacon; 2010. ISBN 978-0-8144-1509-2

[49] Spišák B. Prečo je dôležité budovat' online reputáciu? [Internet]. 2016. Available from: http://www. marketing-tu.sk/preco-je-dolezitebudovat-online-reputaciu/ [Accessed on: 14 December 2016]

[50] Bunting M, Lipski R. Drowned out? Rethinking corporate reputation management for the Internet. Journal of Communication Management [Internet]. 2012. Available from: http:// www.emeraldinsight.com/journals. htm?articleid=1524171/ [Accessed on: 17 January 2013]

[51] Sasko J. Dbáte na hodnotu svojej značky? [Internet]. 2015. Available from: http://www.podnikajte.sk/ manazmentmarketing/c/1392/category/ marketing/article/online-reputacnymanazment.xhtml [Accessed on: 23 March 2018]

[52] Laurenčík J. Online reputačný manažment vo vel'kom. [Internet]. 2010. Available from: http://blog.pizzaseo. com/sk/online-reputacny-manazmentvo-velkom/ [Accessed on: 07 April 2016]

[53] Ross J. Top 5 things that you need to know about online reputation management [Internet]. 2015. Available from: http://www.jseo.com/how-to/ top-5-things-that-you-need-to-knownabout-online-reputation-management [Accessed on: 17 February 2017] 
[54] Wang Y, Vassileva J. Toward trust and reputation based web service selection: A survey. [Internet]. 2007. Available from: http:// citeseerx.ist.psu.edu/viewdoc/ summary?doi=10.1.1.89.6365 [Accessed on: 02 September 2014]

[55] Resnick P, Zeckhauser R. Trust among strangers in internet transactions: Empirical analysis of eBay's reputation system. [Internet].2002. Available from: http:// presnick.people.si.umich.edu/papers/ ebayNBER/RZNBERBodegaBay.pdf [Accessed on: 15 February 2014]

[56] Liu B. Sentiment Analysis and Opinion Mining [Internet]. 2012. Available from: https://www.cs.uic. edu/ liub/FBS/SentimentAnalysis-andOpinionMining.pdf [Accessed on: 09 February 2014]

[57] Koncz P, Presentation. [Internet]. 2013. Available from: http://people.tuke. sk/jan.paralic/prezentacie/MZ/MZ8.pdf [Accessed on: 18 January 2014]

[58] Pollák F, Svetozarovová N, Malinak B. Selected approaches to sustainable development of corporate reputation-empirical study of online reputation management of the best adriatic coast hotels. In: Global Business Conference 2018: Developing New Value-Creating Paradigms. Zagreb: Insitut za inovacije; 2018. pp. 177-219. ISSN 1848-2252

[59] Dorcak P, Markovic P, Pollak F. Multifactor analysis of online reputation as a tool for enhancing competitiveness of subjects from automotive industry. Journal of Economics. 2017;65(2): 173-186. ISSN 0013-3035

[60] Pollák F, Svetozarovová N, Malinak B. Multifactor analysis of online reputation as a tool for enhancing competitiveness of selected tourism entities. Global Business and Economics Review. 2018;20(2):231-247
[61] Pollák F, Soviar J, Svetozarovová N. Selected approaches to sustainable development of corporate reputationempirical study of online reputation management of subjects from the field of supply chain management. In: Carpathian Logistics Congress (CLC) 2018. Ostrava: Tanger; 2018. pp. 324329. ISBN 978-80-87294-88-8 
Section 2

Inevitable Digitalization 



\title{
Chapter 4
}

\section{E-Detailing: Keyways for Successful Implementation of Digital Technologies in the Pharmaceutical Marketing}

\author{
Stefan Balkanski and Ilko Getov
}

\begin{abstract}
E-detailing describes the use of IT tools for promotional activities-delivering information for pharmaceutical products to customers (health professionals, medical personnel, and patients). It includes using electronic channels to interact with customers, as well as electronic support for sales reps in their everyday work. It is a strong and potential tool in the pharmaceutical marketing. This chapter describes the advantages and the challenges in the use of e-detailing.
\end{abstract}

Keywords: e-detailing, electronic visits, pharmaceutical marketing, pharmaceutical detailing, healthcare professionals, pharmaceutical sales representatives, digital marketing

\section{Introduction}

E-detailing (electronic visits, e-visits) is the generalized term to describe the use of digital technology for promotional activities for pharmaceutical products, mainly via the Internet. This approach is more commonly used in the United States but is slowly making its way into Europe.

\section{Methods}

A literature search was conducted in several databases (Google Scholar, Science Direct, and Scopus). A narrative review was undertaken from the published literature on original studies, and systematic reviews published from 2000 to 2019 were included to provide insights into the use of e-detailing. The search was limited to the English language. The data were revised and summarized into a full body review that describes e-detailing as a marketing tool and its implementation in the pharmaceutical industry.

\section{Overview of the pharmaceutical industry}

The pharmaceutical industry is one of the largest and dynamic economic sectors. IQVIA indicates that the global spending on medicines will grow to nearly $\$ 1.5$ 
trillion by 2023 at a 3-6\% compound annual growth rate over the next 5 years-a notable slowdown from the $6.3 \%$ seen over the past 5 years. The patent cliff and the aggressive approaches of the generic companies determine a huge competition on the pharmaceutical market as generic usage in the unprotected market is expected to exceed the health ministry target of $80 \%$ a year early in 2020 [1].

Generally, the pharmaceutical industry is strictly regulated. Promotional activities are under strict legislation. These activities are burdened with ethical consideration and public attention. In the case of pharmaceutical products, the aim of promoting is to inform consumers and healthcare professionals about new treatments available via either direct-to-consumer (DTC) advertisement or in the form of outreach to healthcare professionals by sales representatives who provide to the former up-to-date and accurate information about new chemical entities [2].

The development of new medicinal products, their manufacturing, authorization, and subsequent use (post-marketing surveillance) are closely inspected and controlled. The basic requirements a medical product must meet are in terms of quality, effectiveness, and safety. While quality and effectiveness can be proven in the preclinical phase of development, before marketing authorization, safety data can also be collected after a product's release to market. Furthermore, the development of a new, innovative medicinal product can be an expensive and long process (between 10 and 15 years). There is a need for more investments in research and development (R\&D), often accounting for over $20 \%$ of yearly revenues. Because of that, all new medicinal products are insured and covered by a patent which allows innovative companies to recover the funds used for R\&D and invest into the development of new molecules. The so-called innovative products do not have an analog in the current market and are being developed by $R \& D$ companies. If a patent expires, any company has the opportunity to produce its own generic product. Significant specifications of the industry include taking into consideration patient rights and other ethical norms, for example, animal rights and environmental impact.

Generic products are sold at a considerably lower price, because companies do not have to invest additionally into development, research, and patents. The tendency to remove patents and the decrease in amounts of new medicinal products to reach the market create a very competitive environment at all levels of the pharmaceuticals market.

Increased competitiveness in the traditionally large markets (the United States, Europe, and Japan), as well as the pressure coming from generic producers, forces the big multinational pharmaceutical companies to intensively strengthen their efforts to penetrate and position themselves in the underdeveloped markets. This market expansion is mainly focused on the growing markets in Eastern Europe, the former Soviet Union countries, China, and Latin America. Another approach to address competition is through acquisition and/or merger of former competitor companies $[1,3]$.

Marketing efforts within the pharmaceutical industry differ depending on the relevant recipient; they are not aimed at the product (medicine) user-the patient-but at the medical professional prescribing therapy. The main marketing approach is using sales representatives who meet with medical professionals and present their products' advantages and discuss what types of patients can benefit from the specific medicine. Such meetings, often referred to as "visits," are regulated and scheduled, so that individual sales reps visit multiple doctors per workday.

\section{Pharmaceutical marketing}

One characteristic of pharmaceutical marketing is that, in most cases, it is not directed to the end user of the product - the patients. Exceptions are 
over-the-counter (OTC) products sold without a prescription. In these cases, marketing campaigns are "Direct to Consumer." Pharmaceutical marketing is directed to medical professionals who prescribe medication and have to convince patients that it is the suitable treatment for them. Then patients purchase medication from pharmacies and are responsible for the adherence.

The main aspects of pharmaceutical marketing are the following: (a) stricter regulation of the industry than standard consumer markets where the level of regulation can only be compared to a handful of other sectors (e.g., airline companies), (b) the need for larger investments in R\&D which often account for over $20 \%$ of the revenue, (c) protection of patients' rights, and (d) a variety of ethical factors, as animal rights, environmental protection, and others. The main differences between the pharmaceutical and consumer markets are presented in Table 1 [3].

The direct consumers of pharmaceutical marketing are health specialists. They seek out medical knowledge, administer databases with their patients' medical history records, and to some extent abide by the "price-value" principle. Pharmaceutical companies, which promote products from different therapeutic areas, are usually in contact with numerous health specialists. One of the most important criteria when categorizing those customers is their professional rank, specialty, or professional title. An example for division of medical professionals is general practitioners (GPs), medical specialists (e.g., cardiologists, rheumatologists, endocrinologists), and academic lecturers (associate professors and professors). On the other hand, medical specialists can be divided into specialists involved in outpatient care (ambulatory) and in hospital (inpatient) care. This distinction determines the relevant patient group doctors work with and subsequently their potential for every company. A doctor's professional rank is defined by a hierarchy, which can be observed on all markets (Figure 1) [3].

On the top are the "opinion leaders" (OL), usually university professors or chairpersons of medical associations. Those are the medical professionals who dictate the trends in a specific therapeutic area. They have earned peer respect due to their experience and extensive practice closely connected to using the newest medical products and treatment methods. In terms of influence, OL are followed by managers of clinics or heads of departments, who lead teams of multiple medical doctors. In some cases, the clinics' managers can be the ones to choose the treatment of a specific condition available in their clinic or department. Medical specialists are the next hierarchical level. Their expertise and long-standing experience in their specialty make them valuable consultants in the specific therapeutic area. Next

\begin{tabular}{lll}
\hline & Pharmaceutical market & Consumer market \\
\hline The consumer makes the decision & False & True \\
\hline The consumer pays directly the product & False & True \\
\hline Brand loyalty & High & Low \\
\hline Ethical regulations & High & Low \\
\hline Level of government regulation & High & Low \\
\hline Manufacturer's responsibility & High & Low \\
\hline Degree of R\&D complexity & High & Low \\
\hline Human studies necessity & Yes & No \\
\hline R\&D price & High & Low \\
\hline
\end{tabular}

Table 1.

Comparison between the pharmaceutical and consumer markets [3]. 


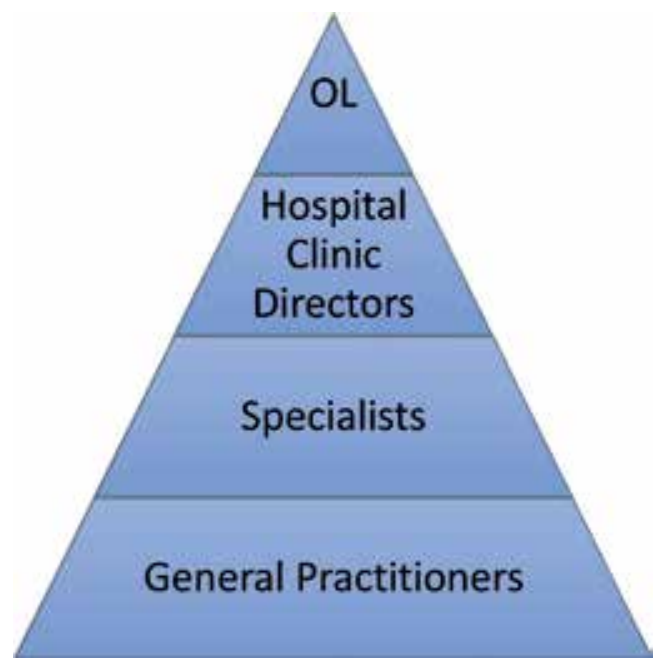

Figure 1.

Pyramid of influence of health specialists-Opinion leaders $(O L)$ [3].

come general practitioners who are not specialized in a particular area and provide care to patients with various health conditions. Usually, they would refer more complicated patient cases to the respective medical specialist.

The pyramid of influence describes the flow of knowledge and influence from opinion leaders all the way to general practitioners (GP). The same flow must be followed by pharmaceutical marketers when introducing a new product to market. In other words, early approval from key industry opinion leaders can be used to cascade influence and share knowledge, aiming to show the advantages of new products down the pyramid. Opinion leaders are often introduced to new products early on during clinical testing processes, making this stage a major responsibility for medical marketing managers.

The decision to prescribe a specific product is a process which attracts the attention of marketers, psychologists, etc. Determining the steps that define decision-making in prescribing a medicine, as well as the factors influencing the decision-making process, can contribute to successful marketing efforts to promote pharmaceutical products to medical professionals. The decision-making process in prescribing medicines starts with choosing a medicinal product from a therapeutic area that is most suitable for the respective health condition, followed by selecting a specific commercial brand out of the whole range of available products in the same area. The steps of both processes are the following: (a) defining the problem, (b) informed search for a suitable treatment, (c) assessing existing alternatives, (d) actual decision-making to prescribe a product, and (e) assessing results from the chosen treatment [3].

\section{Traditional (face-to-face) visits}

The primary promotional channel for pharmaceutical companies to reach medical specialists is in the form of meetings between them and sales representatives, or "visits." During such meetings, the sales representative discusses with doctors the advantages of their company's products and aims to identify suitable patients whom the products can be prescribed to. This process is the biggest expense for pharmaceutical companies [4]. In the United States, the cost of visits accounts for somewhere between 45 and $70 \%$ of the marketing budget. In the period in between 
2009 and 2010, American companies spent about 28 billion dollars for promoting medicines to doctors, some 15.3 billion having been allocated to visits. That makes up for over $54 \%$ of the overall promotional budget. In Europe the percentage is much higher, as direct marketing to patients is not allowed (except for OTC products); subsequently, this item does not even exist within the European companies' marketing budgets. In Europe's five largest markets (France, Germany, Italy, Spain, and the United Kingdom), the overall promotion expense in 2009-2010 exceeded 18.5 billion dollars, with 11.8 billion (or about 60\%) in costs for visits of health specialists [5]. The reason behind this is simple-the approach works. It generates sales for pharmaceutical companies and is beneficial for medical professionalsthey receive useful information about new products, which increases their medical competence. If doctors did not receive extra benefits, their access to sales reps would have been curtailed a long time ago. However, the number of pharmaceutical sales representatives rises continuously in recent years, which leads to a decrease in the quality of visits. Considering this, it is very important to be focused and deliver what is exactly needed by the doctors, and the pharmaceutical companies are looking for new approaches to presenting their products. Still individual sales visits continue to have the most important impact on medical doctors' confidence in pharmaceutical brands, and when deployed well, the combination of digital and physical channels creates flexibility in the promotion effort that can be modeled to meet sales goals with the appropriate resources. At present, healthcare professionals (HCP) do not have sufficient time to see pharmaceutical sales reps, but when they do see them, they expect more educational information from representatives than ever before. Pressured, pharmaceutical companies search for new approaches to introducing their products [6-11].

Campaigns employing digital channels can be more effective than traditional field force promotions. They can offer the opportunity to stand out from competitors through more frequent interactions with target physicians, presenting more varied content, and by leveraging other services (e.g., meet the expert), deploying interactive content and services, exploiting the full potential of new technologies (e.g., tablets), systematic real-time user feedback, and analysis through CRM tools and potential unlimited direct communication between the field force and physicians. In addition to increasing share of voice with current customers, digital marketing solutions can also be used to extend target coverage to other physicians involved in the diagnostic therapeutic path (secondary targets), as well as to other relevant stakeholders [7].

The following challenges can be pointed out when discussing traditional sales representative-medical doctor visits:

Opportunities for individual meetings with medical doctors decrease continuously. Medical specialists get busier and have limited time to spare for meetings with the growing number of sales reps. In the United States, for example, one of five visits with a doctor is successful. Longer distances between specialists from different geographic areas further limit opportunities for personal visits [8]. It turns out that access to specialists working in clinics and hospitals is relatively limited. In just 8 out of 100 attempts to arrange a meeting with professionals practicing in hospitals or clinics do sales representatives manage to talk to doctors [12].

Longer intervals between meetings. The reduced frequency of these meetings leads to limited possibilities for personal contact and can thus prolong the period between a product reaching market and a health specialist getting acquainted with it [8]. Thus far, this problem, for example, has not occurred in Bulgaria, as, despite their busy schedules, Bulgarian health professionals are easily accessible to sales reps. The frequency of visits with key customers can reach up to three times per month. 
Shorter duration of visits. In the United States, a visit lasts between three and four minutes on average, half of these visits lasting no longer than 2 minutes. This span is insufficient for a good enough product presentation for the customer. In $43 \%$ of cases, attempts to reach medical doctors do not make it beyond the reception, and $35 \%$ of US physicians do not meet with sales reps at all. With an average of eight visits daily, the US pharmaceutical sales reps spend $90 \%$ of their time traveling and waiting $[8,9,13]$.

Higher prices per visit. The higher prices are associated with travel costs and waiting time before meeting up with medical doctors, the expenses amounting to 665 British pounds in the United Kingdom and to 2000 dollars in the United States per hour for an effective visit [8]. A study conducted in 2003 on the financial effects of traditional visits shows that the return on investment (ROI) decreased by $42 \%$ compared to 1994 [14].

Inability to provide sufficient information during the visit. During a visit to a medical professional, sales representatives often do not have all information on hand or do not have the knowledge to answer all doctors' questions. On the one hand, this can lead to a beneficial follow-up meeting to discuss the question in detail; on the other hand, this may lead to unwanted delay of the information flow to the doctor or additional work for the sales rep [8]. In Bulgaria, during the last 2 years, using electronic devices (primarily tablets) has become more and more popular and has to a big extent replaced the use of traditional brochures. These devices allow sales reps to have all the needed information handy at every visit and thus limit the problem.

Standardizing communication. During traditional visits, the personality and knowledge of sales representatives are of utmost importance. These qualities can be used as an advantage, but at the same time, it is hard for pharmaceutical companies to assure that their marketing messages are interpreted in the same way throughout the markets [8].

A tendency to incorrectly determine a client's potential. Doctors are divided into different target status groups, according to their potential in relation to a certain product: ones with high potential are with a target " $\mathrm{A}$ " status and are to receive the most visits; ones with lower potential are identified as targets " $\mathrm{B}$ " and "C." Clients with a target rating " $\mathrm{A}$ " are of interest for most companies, and meeting with them becomes harder over time, whereas clients from the target group " $\mathrm{C}$ " are noticeably more easily accessible_-this leads to incorrectly determining a client's potential. This is why the barely accessible " $\mathrm{A}$ " clients are often rated as " $\mathrm{B}$ " targets instead, as this helps sales reps reach their monthly or yearly targets. The same can be observed with " $C$ " clients who are also sometimes regarded as " $\mathrm{B}$ " clients. This leads to ineffectiveness in sales and marketing campaigns [8].

The outcomes are negative tendencies in the sales representatives' results. During the recent years, in the United States, a decrease in the number of medical sales representatives can be observed — from 105,000 in 2005 to 75,000 in 2012—or a decline of $25 \%$ over a 7 -year period [5]. Some of the US doctors tend to decline meetings with sales reps more often than ever. The overall accessibility of health specialists has dropped by half (49\%) in the period in between 2008 and 2014. This trend can be explained with the reduced amount of time available to doctors, as well as with the increasing number of young specialists who prefer receiving information via digital channels and mobile devices [15]. Although a decrease of costs for sales reps can be observed compared to 2005, sales rep visits remain the strongest marketing tool for introducing new products, especially in Europe [16]. Medical specialists still perceive sales representatives as a valuable source of information. Therefore, it is important for pharmaceutical companies to find new ways to reach their customers [15]. Yet, pharmaceutical companies continue to invest substantially in physicianoriented marketing as it has proven more important and effective $[17,18]$. 
A 2014 study in France concludes that individual sales visits continue to have the most important impact on medical doctors' confidence in pharmaceutical brands [19].

\section{Electronic visits (e-detailing)}

As stated above, many factors such as the decline in effectiveness of sales reps, the increased costs for traditional visits, business of medical doctors, and the increasing popularity of online resources result in more frequent use of electronic channels to contact health professionals. A need to search for new communication approaches is generated. Ideas for using modern IT to present new medical products are being explored to support the sales representatives' functions. These integrated approaches are referred to as e-detailing [20].

\subsection{Definition}

E-detailing describes the use of IT tools for promotional activities-delivering information for pharmaceutical products to customers (health professionals, medical personnel, and patients). It includes using electronic channels to interact with customers, as well as electronic support for sales reps in their everyday work. Another definition introduces e-detailing as "a new communication channel for promotion of pharmaceutical products, using digital technologies, mainly via the Internet" [6].

Immediately when pharmaceutical companies begin to plan to use IT in their promotional activities, computer companies introduce e-detailing services. The first company to use e-detailing for its services was founded in 1998_Physician Interactive [21].

The process of using an electronic visit includes the following stages: initially, the pharmaceutical company has to choose a provider of e-detailing services, as well as to determine the end users to be reached via this promotional channel. After that, the service provider must arrange for the technical equipment to be set up for the chosen end users of the pharmaceutical company. Thus, the service provider establishes the connection between the company and customers (Figure 2). During this process, both the pharmaceutical companies and end users are regarded as customers of the electronic service provider [20].

\subsection{Development}

Traditionally, most of the information available on the Internet to medical professionals is static and is mostly found on the company's webpage. This can be useful to medical doctors but only in the sense of one-time visits, as it cannot keep the doctor's attention for longer. This is the main reason why interest toward this communication channel is not developed. The problem is solved by introducing electronic visits, which allows the use of information technologies within the

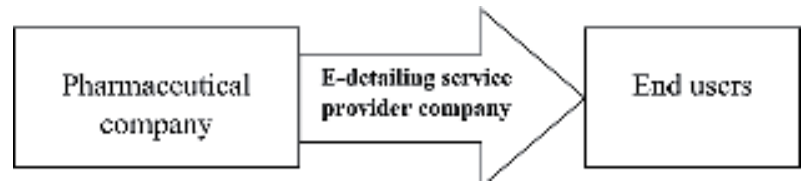

Figure 2.

Communication route in e-detailing [20]. 
process of marketing a new medical product. This is believed to be the e-visit's greatest advantage [20].

A variety of formats of e-detailing exist. They mainly differ in the relationship between medical specialists and the pharmaceutical company's sales representative. In some cases, there is a direct connection between the customer and the sales rep. This connection can be made in real time, through video calls or chat rooms, or at convenient time (e-mail correspondence). In other cases, customers "communicate" with a program and can themselves choose the content they wish to receive. Alternatively, the information the customer is exposed to is not influenced by his/ her behavior. An example for that are Internet websites or news sent via e-mail. The differentiation among the previous three types of interaction is connected to the flexibility of the communication-in the first case, the customer has a larger influence on the flow of information he/she receives [8].

The main communication channels used now - the Internet (accessed through personal computers or mobile devices), interactive digital television, telephone conversations, and personal meetings-are significantly different in their way of communicating, distribution among customers, and ability to present information. A personal computer with access to the Internet as a communication channel allows both synchronistic (chat, video conferences) and asynchronistic (electronic letters) forms of communication. Depending on the available equipment, it could allow forwarding of text, graphics, animations, and videos. On the other hand, using a phone as a communication channel is limited to a synchronistic transmission of sound [8].

In the United States, e-detailing is significantly more developed than in Europe. Data from one of iPhysicianNet campaigns from 2001 shows that sales representatives make 13 video calls per day (compared to the average of 8 with the traditional personal visits). During a video call, they are able to discuss an average of 2.7 products per visit (1.6 per personal visit), where the price of a meeting goes down to $\$ 46$ (compared to $\$ 106$ ) [22]. A research by HyGro Group on the advantages of preparing a script for visits in advance (scripted detailing) shows that using such programs specifically made for products already established on the market results in an increase in prescription rate in the test group from 3.2 to 9.9 percent in 4 months, where group members participated in two e-detailing sessions per month. About $68 \%$ of participating medical professionals rated the program superior to traditional meetings. For this type of visits with high-potential customers, researchers calculate a return on investment (ROI) of $480 \%$ (and increased prescription rate compared to the costs for development of the program) [14].

A number of researches show that the main reason why medical specialists participate in e-detailing campaigns is the opportunity to receive product information at their convenience [20-22]. Convenience has many dimensions-the use of and access to an e-visit are easier [14], meetings with sales reps take shorter [23], and making appointments for visits are at times suiting medical doctors, and the overall time-saver aspect is substantial [21]. About 73\% of electronic visits are conducted after working hours, where $34 \%$ are made during days off and $34 \%$ after 5 pm [14].

\subsection{Types}

The main types of e-detailing found in the United States are the following:

\subsubsection{Video visit}

In this case, medical doctors communicate with representatives of the pharmaceutical company through computers connected to the Internet, with a 
camera and microphone. In this way, specialists can receive details about different products, ask questions, or inquire for additional information [8]. This allows the visualization and presentation of the needed information in a quick and convenient way. Furthermore, doctors are able to schedule the meeting at their convenience and be in control of duration. A visit of this sort usually lasts for about 10 minutes [20]. The main provider of this type of services in the United States is iPhysicianNet. They support a video conference platform financed by pharmaceutical companies. Medical professionals are provided with a free computer and connection to the Internet. In return, medical doctors have agreed to participate in at least one video session per month with every one of the pharmaceutical companies supporting the platform. Video visits are, to a great extent, similar to individual meeting between a doctor and sales rep while allowing freedom in the formats of presenting information [8].

\subsubsection{Telephone conversation while jointly browsing the Internet (co-browsing)}

Just as in the case above, the real-time communication between the medical sales representative (or a call center) and the medical professional is discussed here, where the pharmaceutical company's rep has remote access to the doctor's computer. This allows the sales rep to show the doctor exactly what he/she wants. The doctor and sales rep talk to each other on the phone or through Internet-based telephone lines (IP telephones) and browse Internet-based content simultaneously. The visual connection is missing which renders the method somewhat less personalized than the previous one, hence the more limited use. This type of promotion is used by Novartis in France [8, 20].

\subsubsection{Visits with texts prepared in advance (scripted detailing)}

In this case, medical specialists have access to Internet-based interactive multimedia programs - a blend of flash-based online presentations and online training for a specific product. As a rule, the duration of a presentation like that is somewhere between 4 and 8 minutes. During these presentations, the doctor has the possibility to ask for additional information, for samples, or to get in touch with the sales representative. This method is considered particularly attractive for pharmaceutical companies for its any-day-any-time access to medical doctors and its fairly low price. It is especially effective when a large customer base has to be reached simultaneously. Some of the prominent users of this approach are Johnson \& Johnson, Aventis, Novartis, Amgen, and GlaxoSmithKline [7, 19].

\subsubsection{Interactive voice reply}

This is a type of scripted detailing based on telephone conversations. Customers receive a product presentation over the phone and can participate in it by using voice commands or by pressing the phone's buttons (e.g., to ask for samples). This is a less preferred approach, because it does not include the use of visualization for presenting information $[7,19]$.

\subsubsection{E-mail}

These are personalized electronic messages made to suit the customer's needs that can be used for product presentations, as a separate marketing tool, as well as a part of other marketing strategies. Together with e-detailing, companies use e-mail to invite medical professionals to Internet-based e-detailing programs [8]. 


\subsection{Factors defining the development of e-detailing}

The electronic visit is solely based on modern technologies, and because of that a leading factor in the development of this communication channel is the technology. If an organization uses video visits, the requirements include having a computer camera and microphone to establish a connection between the medical sales representative and the doctor. For such channels to be used, the provider companies need to supply to participating doctors the required equipment, as well as educate doctors on how to operate it. A problem with equipment supply can occur in Europe, because in many EU countries, unlike in the United States, the regulations do not allow pharmaceutical companies to purchase equipment for medical doctors [20].

Compensations are another limitation. A study conducted among medical professionals in the United States shows that additional financial incentives can significantly increase participation rates for electronic visits. About $85 \%$ of the surveyed medical doctors state that "adequate compensation" would motivate them to spend more time on virtual meetings with sales reps (electronic visits) [24]. Another study shows that $40 \%$ of the respondents mainly participated in electronic visits because of the financial compensation they receive [16].

Under the Pharmaceutical Research and Manufacturers of America (PhRMA) Ethical Code on Interaction with Health Care Professionals, compensation for health specialists cannot exceed $100 \$$ [25]. In the United Kingdom, the amount is $6 £$. The legal limitations for further development of e-visits are significantly stricter in EU, and this could be considered as one of the reasons for the slower implementation of this method in comparison to the United States.

Another factor which could influence the development of e-visits is connected to cultural differences. In some countries, such as Sweden, the traditional medical doctor-sales rep meetings are conducted during lunch time. Physicians are provided with information about new products while eating. E-detailing could face challenges trying to overcome this standard [26].

\subsection{Potential advantages}

In an article published in 2003, the potential advantages and disadvantages of e-detailing in Europe are described [8]. Other resources focusing on the benefits are also available online $[27,28]$.

\subsubsection{Low costs per visit}

The absence of travel costs and time spent in waiting for medical doctor, as well as personal expenses, show that introducing products via electronic channels is cheaper. According to a 2001 study, the decrease of expenses with e-detailing in the United States is between 25 and 90\% [29].

\subsubsection{Opportunities for a larger customer reach}

Medical doctors who have a lower potential for prescribing specific medicine and for whom standard visits prove unfeasible can be reached thanks to the lower prices of electronic channels. The flexibility of these channels as well as the ability to present a large amount of information in various formats makes access to medical doctors, who previously limited their meetings with sales reps, easier $[8,20]$. 


\subsubsection{More information available to customers and better ways of classifying it}

E-detailing is an electronic channel, which allows collecting additional information on medical doctor and their interests and practice. If a particular customer shows interest in a specific product or therapy, this allows the pharmaceutical company to better understand the individual interests than a modality where a prescriber passively receives materials from sales reps. It is to be noted that in Europe, distribution of specialized medical information is limited by various regulations [8].

\subsubsection{Reinforcement (synergy) of the effect of standard face-to-face visits}

Up to now, e-detailing is considered more as supplementary to the standard communication methods with health specialists, rather than a replacement. Examples for this supplementary aspect can be receiving information from one channel and using it in another one; medical sales reps have access to content available on the Internet during a visit, and rates of meetings between pharmaceutical companies and medical professionals increased [8].

\subsubsection{Better approval rates from health specialists}

E-detailing allows medical doctors to choose the time, place, and content of a specific meeting themselves and thus avoids disturbance of their workflow. This makes them more prone to receiving information they are interested in and promotes satisfaction $[8,9]$. Medical doctors report that they appreciate the flexibility of e-detailing and use it to arrange meetings outside of their typical working hours [22]. On the other hand, receiving compensation to take part in e-detailing programs is also referred to as an advantage in the United States. It additionally increases loyalty in health specialists, both to the program itself and to the pharmaceutical company [20].

\subsubsection{A more elaborate and faster access to information}

Electronic visits allow the use of various formats of multimedia presentations, which are available to doctors at any place and time [8].

\subsection{Use}

A case study of IQVIA for the European market shows that virtual-only activity improves sales by $65 \%$, as does face-to-face activity alone, while combining faceto-face visits with virtual calls results in more than $95 \%$ increase in sales. The time spent on the virtual platform is on average $78 \%$ longer than audio-only calls [30].

A pharmaceutical company's motivation to engage in e-detailing is determined by different factors: among which the increasing use of Internet among medical doctors, the pharmaceutical companies' wish to provide customers with various alternatives to better understand their medication and increase their customers' brand loyalty, and fear of falling behind of using new channels and subsequently losing market share [20].

Within the past decade, funds invested into e-detailing programs have sufficiently increased. According to a report by Jupiter Research, companies like Aventis, Novartis, and Pfizer invest heavily in programs using electronic visits. In 2002 these expenses amounted to $1-2 \%$ of the company's overall promotional budget, and in 2009 the expense has increased to 9\%. Jupiter Research points out that $56 \%$ of 
pharmaceutical companies invest in e-detailing programs. A study conducted by the same organization aims to show a more in-depth representation of the health specialists' perception of e-visits. Thirteen questions were sent out via e-mail to over 10,000 professionals. Response rate was $9.61 \%$ (961 doctors). About 651 doctors were in primary care and 310 specialists. And $76 \%$ respondents say they currently use an e-detailing program and are completely satisfied with it, 12\% show interest in such a program, and only $12 \%$ are not interested at all [20].

Another study was based on 30-minute interviews with 755 doctors. Results show that $75 \%$ of professionals, who were invited to participate in electronic visits, become regular users. In 2002 doctors spend less than 10\% of their time receiving pharmaceutical information through e-detailing, and this amount is expected to rise to $66 \%$ in 2008 [23].

A number of studies focus on another important indicator for the pharmaceutical industry, namely, the return on investment (ROI). In one particular study Aventis Japan compares the advantages of e-detailing by creating a control and a test group. Participants in the control group receive standard visits, and the test group-both standard and electronic visits. Results show that the test-group doctors prescribe the promoted medicine more often-19-25\% compared to the control group. This increases profits for the pharmaceutical company. E-detailing has a profit/price ratio of 3.2:1, which indicates that for every dollar spent, the company receives 3.2 dollars in profit. Traditional visits have a return of 2.5:1, meaning the ROI of e-detailing is 1.3 times higher than traditional visits [31].

Physician Interactive conducted a research aiming to determine whether the e-detailing program they offer leads to an increase in prescribing medication. The research included 5050 health specialists, who participated in the company's e-detailing program. As part of the program, the duration of interaction between a sales representative and doctor was on average 9.63 minutes and took place over the phone or the Internet. Results show that medical doctors, who participate in the e-detailing program, prescribe the presented product $63 \%$ more often than ones that did not take part in the program.

Another study, conducted by iPhysicianNet, aims to measure the effectiveness of e-detailing programs. An increase of 58\% in the volume of prescriptions has been observed. Further results demonstrate that electronic visits allow for 13 conversations daily, compared to 8 with standard visits. The duration of a visit is 9 minutes on average, compared to 3 with standard visits. With e-detailing, 2.7 products per conversation can be discussed, compared to 1.6 with standard visits, where expenses decreased by $18 \mathrm{~K}$ dollars per year.

Overall, results from these studies show that e-detailing is well received among health professionals and has a positive effect on pharmaceutical companies [20].

\subsection{Challenges}

Using electronic channels to promote medicinal products can burden the marketing budget with additional expenses, at least in the short term. At the same time, there are factors which can cause doubts about the effectiveness of these promotional channels on the market [8].

\subsubsection{Decreasing the overall marketing expenses}

The experience until now shows that e-detailing cannot fully replace traditional meetings of sales representatives with health specialists, at least not in the foreseeable future. Neither specialists nor medical sales reps want to cease face-to-face meetings; therefore, e-detailing campaigns are conducted in parallel 
with traditional visits. Because of that, e-detailing will not lead to a decrease in the pharmaceutical companies' promotion expenses [8].

\subsubsection{Service providers and market structure}

Up to now, the providers of e-detailing platforms are concentrated in North America. The active penetration of these communication channels in Europe is additionally complicated by the heterogeneity of the European markets, compared to the US one. Language and cultural differences among the European countries and regions lower the potential to reach any economies of scale [29].

\subsubsection{Legal restrictions}

Legal requirements and codes of conduct for pharmaceutical companies lower the opportunities for compensating medical doctors for the use of e-detailing. The payment and support models for medical doctors used in the United States cannot be replicated in EU. European companies face the challenge of finding other ways to encourage medical doctors to use these communication channels. There are also differences in the area of personal data protection: it is hard for European companies to collect and process some personal data, and in some cases, this can only be done with the participating persons' explicit consent [8].

\subsubsection{Skepticism and internal resistance}

The team of medical sales reps has an important role in every pharmaceutical company. The fear of losing one's job or of unwanted changes in work practices can lead to resistance to the decision to develop standard visits and can hamper the development of new projects [8].

\subsubsection{Objectivity of information}

More and more health professionals have access to the Internet and use it to search for medical information. Nevertheless, information provided by pharmaceutical companies is still not regarded as trustworthy. Medical doctors rank pharmaceutical companies' web pages low on their list of pages they visit and believe they are not useful. They often refer to their colleagues' opinion, medical literature, and publications as more independent and having bigger influence when receiving information [8].

\subsubsection{Medicinal products'safety}

Additional research is needed to explore the connection between e-detailing and pharmacovigilance. Do doctors participating in such programs receive a better understanding of the mechanism of therapeutic action of a specific medicine and its side effects, compared to standard visits? It is a responsibility of every pharmaceutical company to select information to be presented to medical doctors and to make sure it is clear and correct [20].

\subsubsection{Adopting new communication channels}

The more complicated communication formats, like video conferences or telephone conversations and co-browsing, require effort from the parties engaged, to get acquainted with and accustomed to the technological environment, as well 


\begin{tabular}{lcc}
\hline Criteria & E-detailing & Traditional visits \\
\hline ROI $^{*}$ & High & Low \\
\hline Access to doctors & Easy & Difficult \\
\hline Average duration of visit & Longer & Shorter \\
\hline Cost effectiveness & High & Low \\
\hline${ }^{*}$ ROI: Return on investment. & & \\
\hline
\end{tabular}

Table 2.

Traditional visits versus e-detailing [20].

as with the opportunities it offer [32]. This leads to barriers at the customers' end which pharmaceutical companies have to overcome, e.g., through providing additional training for medical doctors [8].

Another limitation, which could arise while using e-detailing, is the physical inability to leave samples during the visit. This could be easily resolved by providing medical doctors with the opportunity to order samples immediately after the end of an electronic visit [20].

Table 2 shows a comparison between traditional visits and e-detailing.

\subsection{When would e-detailing be most effective?}

It is interesting to discuss at which stage of the product life cycle it is most effective to use e-detailing. At different stages of the product life cycle, the reasons behind a medical doctor's decision to prescribe a product differ. At the beginning and at the end of the product life cycle, the decision is made preferably on an emotional basis, and in the middle, it based on facts or on a rational basis (Figure 3). This leads to pharmaceutical companies' resorting to different approaches. Intuitively, many pharmaceutical companies choose to use e-detailing at the end of a medicine's product life cycle, as an effective way to revive a slowly dying business.

However, this might not be the most suitable moment for using electronic promotion. Effectiveness can be defined by using the rate on which the medical doctor's

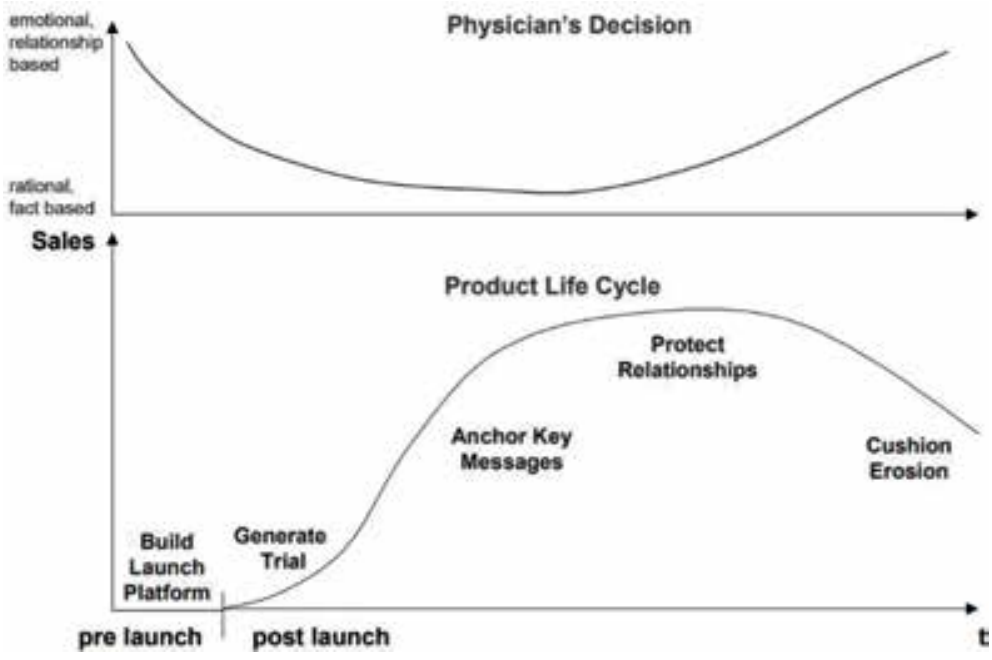

Figure 3.

Marketing objectives and factors influencing a health specialist when prescribing a product, depending on its product life cycle [9]. 
decision to use a certain product is influenced by emotion, based on brand perception or sales rep attitude, or rational, based on facts. Before launching a product to market or immediately after its introduction, there is not much available information on it. A medical professional would base his/her opinion on the trust he/she has in a brand or a sales rep, previous experience, etc. All of these are emotional factors. Over time, when a product is used more often, new studies are made, experience with the product increases, and medical doctors begin to make decisions more on the basis of facts or rationally. When moving into the maturity stage of a product and new, supposedly better medicines enter the market, the medical doctor would continue to prescribe the same product, because he/she believes in it, is used to it, has a good relationship with the company reps, etc. At this stage the medical doctor switches back to taking decisions on an emotional basis. This is the reason why at this stage replacing face-to-face communication with e-detailing can prove a mistake.

IT-based promoting should work best when a large amount of information about a specific product can be provided, so that facts can be presented through using different types of charts, 3D models, animations, etc. The best stage of the product's life cycle could be the stage immediately after launching a product to market, when the company wants to establish the key messages and support them with facts and information [9].

\subsection{Physicians' adoption of pharmaceutical e-detailing}

In 2010 Fadi Alkhateeb published a book on the factors influencing the rate of adoption of e-detailing among physicians [16]. A survey was sent out to 2000 randomly selected health specialist in Iowa, USA. The study explores the influence of innovative characteristics, communication channels, specifications of the specialists, and the social environment on the rate of adoption of e-detailing among medical doctors. The percentage of respondents using e-visits in the sample is 21 . This study repetitively shows that e-detailing is perceived well as a supplement to traditional meetings with sales reps. It turns out that even medical doctors who meet with a sales specialist more often are willing to use e-detailing more often$80 \%$ of those who use e-detailing meet with four or more medical reps monthly (this is a relatively high rate of meetings for the American market). This also shows that pharmaceutical companies use e-detailing as a support tool to traditional visits, rather than as their replacement. Results also show that the framework for determining adoption rates described by Rogers (Figure 4) explains the attitudes of health specialists toward e-detailing.

Better understanding of the advantages of the electronic visit (effectiveness, convenience, use, and work compatibility) on the part of medical doctors increases their proneness to use this communication channel. On the other hand, the study shows that complicatedness when using e-detailing does not have a particular influence on adoption rates. A possible explanation is the fact that pharmaceutical companies and service providers make a great effort in developing easy to use, user-friendly programs and train professionals to work with them. Another factor with a positive influence on e-detailing adoption rates is positive peer experience. Specialists who positively rate the e-detailing approach help the decision-making process of others.

Another aspect researched in the study is the connection between the adoption rates of e-detailing and access limitations to medical doctors. Data shows that medical professionals who have limited access to meetings with sales reps have a lower adoption rate of e-detailing than the ones who are able to meet with medical sales reps on a regular basis. Authors explain the correlation with the fact that medical doctors who practice in inpatient settings where access for sales reps is limited rely on alternative sources of information. 


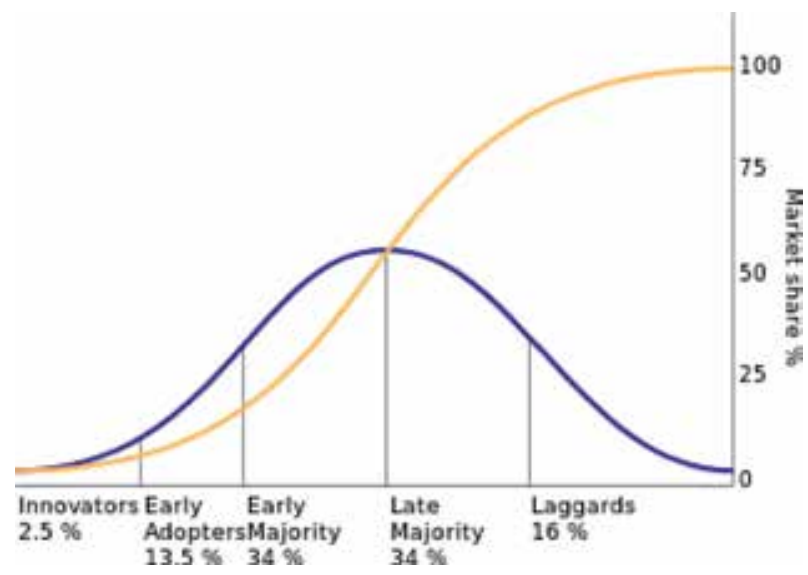

Figure 4.

Perceiving innovation [33].

A result of this study is also the connection found between the years of experience of a medical professional and the adoption rates of e-detailing. The longer the work experience, the stronger the negative effect on adoption rates of e-detailing. This shows that more inexperienced doctors are more inclined to participate in such method of communication, than ones with longer experience (at least 20 years). Younger health specialists are more willing to experiment with new technologies and use new communication channels, as opposed to older ones, who prefer more traditional approaches.

An interesting finding of the study is that practitioners in primary care (ambulatory) are more prone to use e-detailing than specialists. The underlying reason can be that primary care practitioners prescribe a larger variety of medication than specialists. Because of that, primary care practitioners need information on a wide range of medicines and are willing to receive information from multiple channels.

The study shows that men are more inclined to use e-detailing than women. Incorporating some sort of a "gift" as incentive has a positive effect on the adoption rate of e-detailing. The amount of prescriptions issued by health professionals turns out to be a significant factor in using e-detailing-medical doctors who issue fewer prescriptions are less willing to adopt the approach, than those who issue 100 prescriptions per week. The size of a health specialist's practice also greatly influences e-detailing uptake-individual practitioners are more willing to use e-detailing than ones who operate within a group practice [16].

The author of the study points out that the collected data is valid for the state of Iowa and does not claim that the same relations will necessarily be observed with medical professionals elsewhere in the United States or globally. Nonetheless, the study presents robust guidelines as to the possible factors that influence the rate of adoption of e-detailing.

\section{Conclusion}

Our review based on detailed literature search describes e-detailing as a marketing tool and analyzes its potential for implementation in the pharmaceutical industry. Based on our research, we can make the following statements about this method:

- E-detailing tends to supplement traditional meetings between sales reps and health professionals rather than replace them altogether. The main advantage 
of e-visits is not so much to decrease marketing expenses, as to increase the influence over customers. If pharmaceutical companies want to use these advantages, they have to be sure that valuable information about the customers is being received and this information can be used in all other communication channels.

- It is important to define an adequate communication mix when presenting different products. In the earlier phases of the life cycle of a pharmaceutical product, e-detailing can seem rather to attract medical doctors, engage their interest, and satisfy the need for information about a new product. Understandably, customer preferences and their willingness to adopt new technologies are of crucial importance to the success of any new communication mix.

- Although product information is an important factor, its reception will not likely to be a sufficient motivator for a medical doctor to use e-detailing. Because of that, pharmaceutical companies will have to consider other incentives to convince specialists to use the new communication channels. This is also a major problem when discussing development of more projects like that in Europe.

- The electronic visits have the potential of decreasing marketing expenses, increasing access to medical doctors, and preserving at the same time many of the advantages of standard face-to-face meetings. It is a revolutionary method for promoting pharmaceutical products which increases both the quality and the variety of promotional activities of pharmaceutical companies. It proves its benefits for medical doctors and pharmaceutical companies alike. The approach is a major time-saver for the former while ensuring higher ROI for the latter. E-detailing is not a substitute for standard visits but allows medical sales reps to be more effective instead. Therefore, it should be regarded as a supplement to the standard company marketing mix to complement and strengthen the approaches currently in use.

\section{Author details}

Stefan Balkanski ${ }^{1 *}$ and Ilko Getov ${ }^{1,2}$

1 Bulgarian Pharmaceutical Union, Sofia, Bulgaria

2 Faculty of Pharmacy, Medical University Sofia, Sofia, Bulgaria

*Address all correspondence to: st.balkanski@gmail.com

IntechOpen

(C) 2019 The Author(s). Licensee IntechOpen. This chapter is distributed under the terms of the Creative Commons Attribution License (http://creativecommons.org/licenses/ by/3.0), which permits unrestricted use, distribution, and reproduction in any medium, provided the original work is properly cited. (cc) BY 


\section{References}

[1] IQVIA. The Global Use of Medicine in 2019 and Outlook to 2023. Available from: https://www.iqvia.com; 2019. p. 75

[2] Panigrahi A, Aware K, Patil A. Application of integrated marketing communication in pharmaceutical industry. Journal of Management Research and Analysi. 2018;5(2):133-139

[3] Dogramatzis D. Pharmaceutical Marketing: A Practical Guide. Boca Raton, Florida: Taylor \& Francis Group; 2002

[4] Gönül FF, Carter F, Petrova E, Srinivasan K. Promotion of prescription drugs and its impact on physicians' choice behavior. Journal of Marketing. 2001;65(3):79-90

[5] Sridhar S, Mantrala MK, Albers S. Pharmaceutical detailing elasticities: A meta-analysis. In: Innovation and Marketing in the Pharmaceutical Industry: Emerging Practices, Research, and Policies. Springer; 2013. pp. 531-556

[6] Alkhateeb FM, Doucette WR. Electronic detailing (e-detailing) of pharmaceuticals to physicians: A review. International Journal of Pharmaceutical and Healthcare Marketing.

2008;2(3):235-245

[7] Nandy M, Pal B. Pharmaceutical marketing \& product promotion: A paradigm shift in Indian pharmaceutical industry (IPI). Adhyayan: A Journal of Management Sciences. 2016;5(2):27-40

[8] Heutschi R, Legner C,

Schiesser A, Barak V. Potential benefits and challenges of e-detailing in Europe papers potential benefits and challenges of e-detailing in Europe. Journal of Medical Marketing. 2003;3:263-273
[9] Bernewitz TW. E-Detailing: Where Does it Fit in Pharmaceutical Sales? Illinois, USA: ZS Association; 2001. pp. $1-10$

[10] Karaman A, Durmaz Y. A qualitative research on the factors determining product awareness and product preference in promoting medicines by digital tools. Medicine Science. 2018;7(4):923-929

[11] Harris G. Pharmaceutical representatives do influence physician behaviour. Family Practice. 2009;26(3):169-170

[12] Elling ME, Fogle H, McKhann CS. Making more of pharma's sales forcetle. McKinsey Quarterly. 2002;3:87-95

[13] Health Strategies Group. Access to High Prescribers the World of Doorknob Details. Chicago: Health Strategies Group; 1999

[14] Gleason M. Internet detailing opens the doctor's door. Medical Marketing \& Media. 2001;36(1):80-86

[15] Khedkar P. If Physicians Aren't Listening to Sales Reps, What Are they Listening to? Illinois, USA: ZS Association; 2014

[16] Alkhateeb F. Physicians' Adoption of Pharmaceutical E-Detailing: ROI and Metrics. Saarbrucken: LAP Lambert Academic Publishing; 2010

[17] Manchanda P, Honka E. The effects and role of direct-to-physician marketing in the pharmaceutical industry: An integrative review. Yale Journal of Health Policy, Law, and Ethics. 2013;5(2):8

[18] Fischer M, Albers S. Patient-or physician-oriented marketing: What 
drives primary demand for prescription drugs? Journal of Marketing Research. 2010;47(1):103-121

[19] Andreani J-C, Rokka J, Moulins J-L, Conchon F. Digital marketing effects and synergy in IMC - insights from... Pharmaceutical industry. Acedido a. 2014;20:1-39

[20] Montoya ID. E-detailing: Information technology applied to pharmaceutical detailing. Expert Opinion on Drug Safety. 2008;7(6):635-641

[21] Bates A, Bailey E, Rajyaguru I. Navigating the e-detailing maze. Journal of Medical Marketing. 2002;2(3):255-262

[22] Junger D. E-Detailing: The Future of the Primary Care Salesforce. In Pharm. com; Guildford, UK; 2001

[23] McKillen D. E-detailing gaining acceptance among physicians. Medical Marketing \& Media. 2002;39(9):62-72

[24] Banerjee S, Dash SK. Effectiveness of e-detailing as an innovative pharmaceutical marketing tool in emerging economies: Views of health care professionals of India. Journal of Medical Marketing. 2011;11(3):204-214

[25] Davidson T, Sivadas E. Success is in the E-tails. Marketing Health Services. 2004;24(1):20-26

[26] Flanagan A, Guy P, Larsson S, Saussois C. European Physicians and the Internet. Boston, USA: Boston Consulting Group; 2003

[27] Getshaman.com. The 5 advantages for e-detailing in pharma - Shaman [Online]. 2018. Available: https:// getshaman.com/blog/the-5-advantages- for-e-detailing-in-pharma/ [Accessed on: 28 May 2019]

[28] Skura.com. E-detailing, E detailing Pharma | SKURA [Online]. 2018. Available: http://www.skura.com/ edetailing.php [Accessed on: 28 May 2019]

[29] Boehm EW, Brown EG, Kari M. Pharma's Detailing Overhaul. Cambridge, USA: Forrester Rep; 2001

[30] IQVIA. ADDING VIRTUAL ENGAGEMENT IMPROVED SALES BY OVER 95\% Successfully Utilize Engagement Preferences. IQVIA Institute for Human Data Science; 2018

[31] Matsubara K. E-detailing boosts ROI. Pharmaceutical Executive. 2003;23(5):126

[32] Sauer J, Schramme S, Rüttinger B. Knowledge acquisition in ecological product design: The effects of computer-mediated communication and elicitation method. Behaviour \& Information Technology. 2000;19(5):315-327

[33] Rogers Everett M. Diffusion of Innovations. New York: Free Press; 1995 



\title{
Cheers in UK: How Visible Are Spanish Sparkling Wines on Google.co.uk?
}

\author{
Carlos Gonzalo-Penela, Noelia Jiménez-Asenjo \\ and Diana A. Filipescu
}

\begin{abstract}
In this chapter, we apply qualitative and quantitative analysis techniques with the aim of measuring the visibility of websites in searches for Spanish cava or sparkling wine made using the UK version of Google. Using the Google Ads Keyword Planner, we retrieved a group of searches in the semantic field of 'sparkling wines' and monitored the results. Extraction and also cybermetric analysis of Search Engine Result Pages (SERPs) using SEO techniques were used to calculate the visibility of Spanish cava brands via their own websites and e-commerce websites, whereupon we were able to establish rankings of media, social networks, wine sites and e-commerce websites as well as recommendations for content optimization.
\end{abstract}

Keywords: cava, sparkling wine, United Kingdom, SEO, Google, visibility, SERPs, web scraping, Google Ads, search frequency, e-commerce mapping

\section{Introduction}

In recent decades, the wine sector has undergone major structural changes due to globalisation and increased international competition [1]. It is a highly

fragmented sector where exports from the traditional producer countries (France, Italy and Spain) are being challenged by new producers, such as Australia, California, Chile, Argentina and South Africa, the latter dubbed 'New World Producers'.

Consumers are also changing globally. This is not only a geographic shift in terms of where exports are being directed, with the emergence of new markets such as China, but also a shift in terms of consumer tastes, whereby they are now opting for better quality wines and the satisfaction of more complex needs [2], something legitimate and linked to the cultural attributes associated with the product itself.

All these changes have had an impact on production, with numerous wineries, territories and countries battling to position their wines worldwide. Hence Denominations of Origin (DOs) are created, which help to certify the particular quality of wine products, whose production is limited to certain geographical areas, which in turn protects them from competition and fosters their promotion, status and international recognition. The most globally recognised DOs of sparkling wine are French Champagne, Spanish Catalan Cava and Italian Prosecco.

Although bottled still wine was the highest selling product worldwide in 2017, with a market share of $71 \%$ in value and $54 \%$ in volume, sparkling wines are gaining 
ground, with exports rising globally by $11.2 \%$ in volume and $8.9 \%$ in value; although they only represent $8 \%$ of the total exported volume, in terms of value that figure rises to $19 \%$ [3].

The main exporters of sparkling wine worldwide are Italy, with a market share of $41 \%$, followed by France, with $24 \%$ and Spain with $22 \%$. However, the average value of an exported bottle of Italian sparkling wine is $€ 2.80$, while that of Spanish sparkling wine is $€ 1.84$, and that of French is as high as $€ 12.60$, due to the high average price of champagne, $€ 18.20$ a bottle [4].

Champagne is a sparkling wine produced using the champenoise method whereby the second fermentation occurs inside each bottle, thus obtaining a superior quality product. Such high quality, status and global reputation make it the indisputable market leader. In 2017, global consumption of champagne amounted to $40 \%$ of the value and $13 \%$ of the volume of all sparkling wine, with France and the UK being the main consumer markets for this precious liquid [4].

Catalan cava is an alternative to champagne. It is made by the same production process as champagne, but the price is lower, so it is highly appreciated on the market for offering good value for money. Because of this, exports have grown exponentially since the 1990s to reach 162 million bottles in 2017, with sales led by the Freixenet and Codorníu companies.

Likewise, in recent years, Italian Prosecco has become one of the leading sparkling wines on the international market, regarded as a fashionable but cheaper alternative to French champagne. It costs less than champagne and cava because it is produced using the charmat method by which the second fermentation occurs in stainless steel tanks, which brings down production costs in comparison with the champenoise method. In 2016, Prosecco exports to the UK exceeded those of champagne in terms of value, and forecasts suggest it will become the fastest-rising sparkling wine in terms of worldwide sales $[4,5]$.

As for the main countries that import sparkling wine, the UK tops the ranking in terms of value, playing its part in the upward trend in sparkling wine consumption, with a 76\% increase in sales from 2012 to 2017 [4]. In 2015, 80.4 million litres of Italian sparkling wine were sold in the UK, followed by the 28 million litres of French sparkling wines and 20.2 million litres of Spanish sparkling wines $[6,7]$.

The Spanish wine sector, through the internationalisation of its wineries and designation of origin (DO) wines, is highly prestigious and internationally renowned. It is a key sector of the Spanish economy, culture and gastronomy, and has now reached full maturity [8]. However, the economic crisis that began in 2007 led to a decrease in domestic sales and stock accumulation, leading many companies, especially SMEs, to begin or intensify internationalisation processes (ICEX, 2013).

In this chapter, we shall be analysing the visibility of websites when searching for Spanish cava or sparkling wine using the UK version of the Google search engine.

In consideration of technological progress and the increase in online sales, a recent report by the RAW agency on 'The digital behaviour of Spanish wineries' [9] states that only two out of every 10 Spanish wineries get more than 10,000 visits to their website per month and in most cases these are limited to visits from inside Spain. In turn, a large proportion of Spanish wineries' foreign sales are made through wholesalers, since most of their websites are not addressed at the international digital market or at direct sales of their products. All of this suggests that there is a huge opportunity for them to increase their sales through a greater presence in the digital market, especially in the UK market that tops the rankings for the online sale of alcoholic beverages.

Estimates of international traffic generated with the SemRush digital marketing instrument show that only seven of the 10 highest selling Spanish wineries receive traffic from the UK (Table 1). 
Cheers in UK: How Visible Are Spanish Sparkling Wines on Google.co.uk?

DOI: http://dx.doi.org/10.5772/intechopen.89541

\begin{tabular}{lccc}
\hline & & Spanish traffic (\%) & UK traffic (\%) \\
\hline 1 & garciacarrion.es & 35.67 & 7.17 \\
\hline 2 & felixsolisavantis.com & 36.91 & 5.63 \\
\hline 3 & freixenet.es & 51.09 & 7.53 \\
\hline 4 & codorniu.com & 22.59 & 14.29 \\
\hline 5 & torres.es & 31.95 & 3.21 \\
\hline 6 & gonzalezbyass.com & 71.87 & 11.66 \\
\hline 7 & felixsolis.com & 29.57 & 2.42 \\
\hline 8 & pernodricardbodegas.com & 89.58 & 0 \\
\hline 10 & movialsa.es & 100 & 0 \\
\hline
\end{tabular}

Table 1.

Estimate of traffic from Spain and the UK (source: Semrush.com).

Although the instrument does not define the types of traffic (whether it is direct, via social networks, via links in newsletters or via search engines), the purpose of our study is to measure a website's visibility based on of the contents that appear on Search Engine Result Pages (SERPs).

\section{Research goals and questions}

The main objective of this study is to analyse the visibility of the Spanish sparkling wine brands on the UK version of the Google search engine, that is, to identify the websites that appear in the results of searches for 'cava' and thereby determine how well positioned Spanish cava brands are.

Our specific goals are:

1. Mapping of all websites visible on Google.co.uk when making searches related to Spanish cava or sparkling wines, in order to identify websites that, to a greater or lesser extent, produce content that appears on SERPs in response to searches related to 'cava'.

2. Analyse the Google visibility of the websites of Spanish sparkling wine brands. By mapping, we are able to identify sparkling wine websites and classify them by nationality, in order to accurately measure the visibility of websites belonging to Spanish brands and/or with a Spanish IP address.

3. Analyse the Google.co.uk SERP visibility of press, social network and sector website results in order to measure their weight and importance in the organic results, thus recognising the websites that are best rewarded by Google in these categories.

4. Analyse the visibility of retailers that appear in Google results and which offer Spanish sparkling wine brands, from specialist stores to major supermarket chains.

Bearing these objectives in mind, the research questions that this study will be looking to answer are the following:

RQ1. What kind of information does Google.co.uk show when British users search for Spanish sparkling wines? 
RQ2. What is the relative weight of the websites of Spanish sparkling wine brands in Google.co.uk results?

RQ3. What media, social networks and sector websites are shown by Google when searching for Spanish sparkling wines from the UK? What is their relative weight?

RQ4. Which are the main e-commerce websites in terms of their visibility?

\section{Conceptual framework}

It is well known that the vast majority of Europeans routinely use search engines to access the information available on the web, and that the links appearing on SERPs are their main point of access to the web immediately after performing a search using their search engine of choice. In the UK in 2018, Google had a market share of $89.1 \%$ of all searches made on search engines, thereby acting as gatekeeper [10] in terms of access to information, meaning that its search engine results pages are the best showcase for companies seeking to promote their products or services.

Search engine results pages (hereinafter SERPs) are one of the central objects of study in Search Engine Optimization (SEO), because they reveal what Google 'considers' to be the best possible response to the searches made by users, and if a website is viewed by Google to be one of the best answers to a query, that page will be ranked high on SERPs and will therefore benefit from the enormous flow of traffic that stems from being in the top positions.

At first, Google's SERP offered 10 organic results, that is, 10 links to web content that had previously been located by Google crawlers and that the search engine ordered by how relevant they were to its algorithm's criteria. However, since the incorporation of the Google Universal and Blended Results algorithm [11], its SERPs have undergone constant change and currently consist of a variety of elements that appear along with the 10 original organic results. These elements include images, videos, news, local results, social network content and special results generated by the search engine itself based on web content that it has been discovered during its page crawling and indexing processes. The most prominent of these elements include the Knowledge Graph [12], 'One Box' responses and, since 2018, the 'Related Searches' that appear in more than $80 \%$ of the searches we make.

However, despite the many elements that the search engine displays on its results page, as many as $84 \%$ of clicks are concentrated in the first four results [13], which makes the highest part of the SERP an extremely competitive space, not only for the websites that are looking to gain traffic by appearing in the top results, but also for the search engine itself, which fills up much of this space with its own elements.

With the aim of cataloguing and measuring the visibility of contents appearing on SERPs when performing searches related to Spanish cava and sparkling wine, the following study analyses SERP composition using the Infosphere model proposed by Peretti [14] and Bennett [15]. This media ecology applied as an open system of categorisation [16] can classify any content and measure its weight and importance on SERPs using a system composed of three well-differentiated and clearly identifiable strata, namely:

- The Conventional Layer corresponds to the media and is made up of cybermedia, meaning both the conventional press, and any other newspaper or magazine that is published on the web.

- The Middle Layer consists of millions of websites and includes leading domains on any subject.

- The Micro Layer includes social networks and the blogosphere. 
Each of these layers contains different sectors and conglomerates, groups of domains that all share a characteristic sector or theme. The system includes a database of websites thanks to which it is possible to identify and measure the proportion of websites appearing on SERPs individually or together with other sites in the same category. In addition, as it is an open system, the database can be expanded with new thematic conglomerates depending on the nature of the research, as we have done with our sample.

\section{Methodology}

This research is a longitudinal study over a period of time that analyses the composition of the SERPs shown by Google when we search for a specific topic, in our case related to the Spanish sparkling wine. The study combines quantitative and qualitative methodologies to analyse a series of samples of potentially visible SERPs in searches conducted from the UK. The qualitative analysis allows us to recognise different types of results shown by Google in its SERPs, as well as the different types of websites depending on their characteristics and themes. On the other hand, a quantitative analysis is applied to the categorisation derived from the qualitative analysis, thanks to which we can measure the weight of any of the sample categories.

Thus, the present study analyses a sample of Google.co.uk results found between May and November 2018 using a set of keywords related to 'cava'. The retrieval of these terms together with their frequency per month is the first step of the methodology, a list of keywords used in the UK to find information about sparkling wines or to buy them.

Using the Google Ads 'Keyword Planner' tool, previously known as Google Adwords, we were able to extract lists of keywords related to any term along with its monthly frequency in the last 4 years. The interface can be used to select any country in the world and extract results that are broadly or closely related to the initial search term.

In order to find out the search frequency of the different terms associated with this search niche, we checked four 'seed terms' in the planner: on the one hand, the term 'cava' together with its biggest French and Italian competitors, 'champagne' and 'prosecco', and on the other hand, the generic term 'sparkling wine'.

These four initial terms, after several iterations, produced a total of 2280 queries that had gathered an average of 481,640 searches per month during the previous 4 years.

There were 752 retrieved queries including the term 'prosecco', which accumulated an average of 215,000 searches a month, followed by those that include the term 'champagne', of which there were 691, but which accumulated a higher average of around 224,000 searches a month. At a considerable distance behind, we were able to identify 289 searches that included the term 'cava' and which accumulated around 22,000 searches per month, a lower figure than the 682 queries in which the term 'sparkling' appeared, which accumulated about 24,000 searches per month. Also, and to a lesser extent, 42 related terms were identified that include the term 'fizzy' and accumulated about 1500 searches a month (see Table 2).

In the aforesaid large groups, we can find searches that include more than one of the national terms that we use to describe sparkling wine. Searches that include 'champagne' and 'prosecco' have an average monthly frequency of 2610 searches, followed by those featuring the term 'champagne' together with 'cava' with 700 searches a month and 'cava' and 'Prosecco' with 640.

Once the keywords had been retrieved, we selected a subset of 24 representative terms, including the term 'cava' along with various search modifiers, which we 


\begin{tabular}{lcc}
\hline Seed term & Number of retrieved queries & Searches per month \\
\hline 'champagne' & 691 & 224,000 \\
\hline 'prosecco' & 752 & 215,000 \\
\hline 'cava' & 289 & 22,000 \\
\hline 'sparkling' & 682 & 24,000 \\
\hline 'fizzy' & 42 & 1500 \\
\hline
\end{tabular}

Table 2.

Seed term and number of retrieved queries and accumulated average monthly frequency.

\begin{tabular}{|c|c|c|c|c|}
\hline Keyword & Searches per month & 2016 & 2017 & 2018 \\
\hline Cava & 9900 & 97,900 & 102,100 & 113,700 \\
\hline Spanish sparkling wine & 1300 & 11,720 & 13,150 & 19,820 \\
\hline Cava champagne & 390 & 4370 & 3960 & 3530 \\
\hline Spanish cava & 260 & 4210 & 2420 & 3110 \\
\hline Best cava & 210 & 2750 & 2180 & 2130 \\
\hline Cheap cava & 170 & 2190 & 1850 & 1910 \\
\hline Pink cava & 140 & 1470 & 1580 & 1690 \\
\hline Bottle of cava & 140 & 1450 & 1350 & 1570 \\
\hline Rose cava & 140 & 1390 & 1270 & 1330 \\
\hline Cava rose & 110 & 1250 & 1130 & 1000 \\
\hline Spanish fizzy wine & 40 & 790 & 320 & 280 \\
\hline Cava sparkling wine & 70 & 680 & 540 & 730 \\
\hline Spanish cava brands & 40 & 490 & 360 & 420 \\
\hline Cava Spanish wine & 20 & 320 & 170 & 270 \\
\hline Best Spanish cava & 10 & 240 & 170 & 160 \\
\hline Spanish sparkling white wine & 30 & 230 & 320 & 560 \\
\hline Spanish sparkling wine list & 10 & 180 & 110 & 80 \\
\hline Sparkling cava & 10 & 150 & 150 & 130 \\
\hline Spanish champagne cava & 10 & 140 & 110 & 110 \\
\hline Spanish sparkling red wine & 10 & 100 & 100 & 100 \\
\hline Best cava sparkling wine & 10 & 90 & 60 & 70 \\
\hline Cava sparkling wine brands & 10 & 70 & 40 & 40 \\
\hline Spanish sparkling wine brands & 10 & 60 & 70 & 70 \\
\hline Spanish sparkling wine cava & 10 & 110 & 120 & 110 \\
\hline
\end{tabular}

Table 3.

Terms selected for extraction and their average monthly and accumulated frequency for the years 2016-2018.

proceeded to use as the main terms for extracting Google UK search engine results, both organic and those paid for using the Google Ads service. Table 3 shows the keywords used along with their monthly and accumulated average frequency for the years 2016-2018.

As mentioned before, we start from a database of more than 60,000 sites, which include media websites from different countries, the most popular online social networks, as well as relevant sites and blogs on a variety of topics. We can use this 
Cheers in UK: How Visible Are Spanish Sparkling Wines on Google.co.uk?

DOI: http://dx.doi.org/10.5772/intechopen.89541

\begin{tabular}{lcc}
\hline Search engine & URLs & Websites \\
\hline Google.co.uk Mobile & 36,316 & 682 \\
\hline Google.co.uk Universal & 35,986 & 661 \\
\hline Google.co.uk Pay per click & 2193 & 59 \\
\hline Total & 74,495 & 757 \\
\hline
\end{tabular}

Table 4

Total sample by search engine of the Top 5 SERPs.

database to take any sample of results and identify and measure those that belong to the Conventional Layer or the Micro Layer. Depending on the subject of the seed terms, each new capture of results presented new websites that had not been identified previously and that needed to be categorised.

The new capture of results with a set of terms related to cava allowed us to locate unknown websites that are categorised via a semi-automatic process that recognises the type and topic from the domain name, elements of the Uniform Resource Locator (hereinafter, URLs) and the metadata that we extract afterwards. These new websites mostly belong to the Middle Layer, especially when the thematic niche had not been mapped before.

Once the keywords had been selected, we applied Search Engine Optimization (hereinafter, SEO) tools to extract the Google.co.uk results for each term. The instrument used in this phase was Advanced Web Ranking Cloud, which was programmed to extract both the Top5 SERPs from the Mobile and Universal (desktop) versions, and results for paid Google Ads, which include advertisers who have bid for each of the terms used.

The data capture period lasted for 29 weeks from May to November 2018 (see Table 4), resulting in a sample of 72,302 organic results taken from Google.co.uk Mobile (36,316 URLs) and Google.co.uk Universal (35,986 URLs), and 2193 results from Google.co.uk Pay per Click (Google Ads). After retrieving the visible URLs from the organic results and advertisements, the parameters of the URLs were deleted and the domain names isolated, enabling us to identify a total of 757 different websites and 59 advertisers.

To measure and analyse the size of the different sectors and conglomerates, we have a database of previously categorised sites, a pre-established group of homogeneous conglomerates common to samples from different niches (press, social networks, government websites, etc.). However, during this data capture process, new sites were discovered and to categorise them, new conglomerates were created that fit specific types of websites that appeared in our sample, such as international sites of sparkling wine brands, liquor stores, websites and blogs on the wine world and a series of lesser sites that showed up in the sample. In this case, a database of national and international websites linked to the wine world was developed that includes more than 4000 Spanish wineries and thousands of websites and blogs.

Then all the results with visibility were categorised by layer, sector and conglomerate, followed by analysis of the complete dataset according to type of site, which of these categories they belong to and their position.

All the visibility calculations were performed on Excel spreadsheets, and dynamic tables were used to analyse the subsets of data.

To summarise, the following process was observed in order to answer the research questions:

1. Extraction of a list of searches made from the UK related to sparkling wine and cava using the keyword research features of the Adwords and SEMrush instrument. 
2. Selection of a set of 24 representative searches.

3. Scraping of the first five pages of results of each search on Google.co.uk using the Advanced Web Ranking Cloud instrument.

4. From the resulting package of SERPs, the URLs were extracted and the domain names to which they belong were isolated.

5. The domains were categorised by type and grouped into homogeneous conglomerates.

6. The composition of the results of the sample was analysed.

\section{Results}

The top five SERPs for each term were retrieved using scraping processes, extracting a sample of 74,495 URLs from Google.co.uk Pay per Click, Google.co.uk Mobile and Google.co.uk Universal. Categorisation of the domains of all the URLs in the sample enabled us to generate a database of websites that could provide an answer to the four research questions about the visibility of websites in the Top4.

The first research question asked what kind of information Google.co.uk shows when British users search for Spanish sparkling wines.

Table 5 shows the distribution of results by device used and the type of content that appeared in the Top5 SERPs. Most of the retrieved contents are organic results, $77.23 \%$ of the total, followed by images with 7.73\%, Accelerated Mobile Pages (AMP) only detected on Mobile with 7.15\%, and Related Questions with 5.98\%.

The weight of the remaining content is considerably lower, as shown in Table 5. Videos, mostly from YouTube, account for $1.08 \%$ of the total, and 'One Box' only amounted to $0.75 \%$.

The aforesaid proportions change substantially when we focus on the results that appear in the visible part of the SERP, that is, the top four results. Table 6 shows the same distribution as in the previous table but only for the Top4.

When analysing this sample we note that the organic results represent only $32.79 \%$ of the results (28.74\% on mobile and $36.85 \%$ on desktop) and the remarkably high visibility achieved by the Related Questions section in the top part of the SERP with an average of $43.86 \%$, while that figure rises to $48.96 \%$ in the

\begin{tabular}{lcccccc}
\hline Type of content & Google.co.uk Mobile & $\%$ & Google.co.uk Universal & $\%$ & Total & $\%$ \\
\hline Organic & 24,765 & 68.19 & 31,073 & 86.35 & 55,838 & 77.23 \\
\hline Images & 3587 & 9.88 & 2004 & 5.57 & 5591 & 7.73 \\
\hline AMP & 5168 & 14.23 & 0 & 0.00 & 5168 & 7.15 \\
\hline Related questions & 2145 & 5.91 & 2176 & 6.05 & 4321 & 5.98 \\
\hline Videos & 388 & 1.07 & 396 & 1.10 & 784 & 1.08 \\
\hline One Box & 254 & 0.70 & 289 & 0.80 & 543 & 0.75 \\
\hline Twitter & 6 & 0.02 & 24 & 0.07 & 30 & 0.04 \\
\hline News & 3 & 0.01 & 24 & 0.07 & 27 & 0.04 \\
\hline
\end{tabular}

Table 5 .

Type of contents that appeared in the sample. 
Cheers in UK: How Visible Are Spanish Sparkling Wines on Google.co.uk?

DOI: http://dx.doi.org/10.5772/intechopen.89541

\begin{tabular}{lcccccc}
\hline Type of content & Google.co.uk Mobile & $\%$ & Google.co.uk Universal & $\%$ & Total & $\%$ \\
\hline Related questions & 1079 & 38.76 & 1363 & 48.96 & 2442 & 43.86 \\
\hline Organic & 800 & 28.74 & 1026 & 36.85 & 1826 & 32.79 \\
\hline One Box & 240 & 8.62 & 289 & 10.38 & 529 & 9.50 \\
\hline Images & 337 & 12.10 & 62 & 2.23 & 399 & 7.17 \\
\hline AMP & 200 & 7.18 & & 0.00 & 200 & 3.59 \\
\hline Videos & 127 & 4.56 & 37 & 1.33 & 164 & 2.95 \\
\hline News & 1 & 0.04 & 5 & 0.18 & 6 & 0.11 \\
\hline Twitter & & 0.00 & 2 & 0.07 & 2 & 0.04 \\
\hline
\end{tabular}

Table 6.

Type of contents that appeared in the Top4 of the sample.

desktop version. The sample hence evidences the visual preponderance of these questions generated by Google over the other contents, even above the organic results.

Next, we applied the different Infosphere levels to the sample of results for the Top4, which allowed us to group the different websites according to which of the three main layers they belong to, and at a lower level by grouping them into sectors and conglomerates (see Table 7).

On the first level of analysis, we distinguish the three layers into which the Infosphere model is divided. The results from the Conventional Layer make up $56.48 \%$ of the total (3.145 URLs), followed by the Middle Layer with 34.72\% (1.933 URLs) and the Micro Layer with an average of $8.80 \%$ (490 URLs). However, we note that the proportions of the first two layers vary considerably in terms of Mobile and Desktop results, with a difference of 10 points more for media content in the Desktop version.

On the next level of analysis, we find a subcategory called Sector that encompasses sites that share common characteristics either in terms of sector or topic. In the Conventional Layer, we find two very distinct sectors, results coming from the press on the one hand, and results generated by Google on the other. On this level, we observe that the results generated by the search engine accumulate $43.89 \%$ compared to those by the press, which only amount to $12.59 \%$. The most prominent sectors in the Middle Layer include the group of sites dealing with e-commerce $(14.03 \%)$, followed by websites on various topics (13.06\%) and sites about the wine sector $(6.72 \%)$.

Finally, we calculated the proportions on a conglomerate level, where $43.89 \%$ of the search engine's results are 'Related Questions', followed by the British Press conglomerate with $12.07 \%$. In third place, we find the Middle Layer conglomerates that group food and drink websites with $10.65 \%$, followed in fourth and fifth place by the conglomerates that group Supermarkets and Liquor Stores with 8.21 and $3.95 \%$, respectively.

Focusing now on the second research question that enquires about the weight of the websites of Spanish sparkling wine brands in Google.co.uk results, we observe that the visibility of the Spanish brands that appear in UK results of is practically non-existent (see Table 8). The Freixenet brand stands out as the undisputed leader in terms of visibility both for mobile and desktop searches with 1169 ranked URLs, $1.5 \%$ of the total sample. The brand has the advantage of owning as many as four different domains, freixenetusa.com, freixenet.com, freixenet.es and $f$ reixenet.co.uk, the first of which features in 19 of the 24 searches. Its biggest 


\begin{tabular}{|c|c|c|c|c|c|c|}
\hline Strata $>$ sectors $>$ conglomerates & $\begin{array}{l}\text { Google.co.uk } \\
\text { Mobile }\end{array}$ & $\%$ & $\begin{array}{l}\text { Google.co.uk } \\
\text { Universal }\end{array}$ & $\%$ & Total & $\%$ \\
\hline 1. Conventional Layer & 1424 & 51.15 & 1721 & 61.82 & 3145 & 56.48 \\
\hline Google & 1079 & 38.76 & 1365 & 49.03 & 2444 & 43.89 \\
\hline Related Questions & 1079 & 38.76 & 1365 & 49.03 & 2444 & 43.89 \\
\hline Mass-Media & 345 & 12.39 & 356 & 12.79 & 701 & 12.59 \\
\hline 5Press-UK & 331 & 11.89 & 341 & 12.25 & 672 & 12.07 \\
\hline 5Prenss-Financial & 9 & 0.32 & 8 & 0.29 & 17 & 0.31 \\
\hline 5Press-USA & 5 & 0.18 & 7 & 0.25 & 12 & 0.22 \\
\hline 2. Middle Layer & 1104 & 39.66 & 829 & 29.78 & 1933 & 34.72 \\
\hline Ecommerce & 443 & 15.91 & 338 & 12.14 & 781 & 14.03 \\
\hline Supermarket & 258 & 9.27 & 199 & 7.15 & 457 & 8.21 \\
\hline Spirits & 129 & 4.63 & 91 & 3.27 & 220 & 3.95 \\
\hline Food & 23 & 0.83 & 21 & 0.75 & 44 & 0.79 \\
\hline Amazon & 22 & 0.79 & 19 & 0.68 & 41 & 0.74 \\
\hline Ecommerce & 11 & 0.40 & 8 & 0.29 & 19 & 0.34 \\
\hline Website & 415 & 14.91 & 312 & 11.21 & 727 & 13.06 \\
\hline Food and drink & 335 & 12.03 & 258 & 9.27 & 593 & 10.65 \\
\hline Entertainment & 34 & 1.22 & 26 & 0.93 & 60 & 1.08 \\
\hline Thematic website & 25 & 0.90 & 28 & 1.01 & 53 & 0.95 \\
\hline Home & 21 & 0.75 & & 0.00 & 21 & 0.38 \\
\hline Wine industry & 223 & 8.01 & 151 & 5.42 & 374 & 6.72 \\
\hline Wine website & 197 & 7.08 & 123 & 4.42 & 320 & 5.75 \\
\hline Agro-tourism & 26 & 0.93 & 28 & 1.01 & 54 & 0.97 \\
\hline Business & 23 & 0.83 & 28 & 1.01 & 51 & 0.92 \\
\hline Travel-tourism & 21 & 0.75 & 19 & 0.68 & 40 & 0.72 \\
\hline Restaurants & 1 & 0.04 & 5 & 0.18 & 6 & 0.11 \\
\hline Hotels & 1 & 0.04 & 4 & 0.14 & 5 & 0.09 \\
\hline 3. Micro Layer & 256 & 9.20 & 234 & 8.41 & 490 & 8.80 \\
\hline Red-Social & 256 & 9.20 & 234 & 8.41 & 490 & 8.80 \\
\hline Wikipedia & 134 & 4.81 & 192 & 6.90 & 326 & 5.85 \\
\hline YouTube & 120 & 4.31 & 39 & 1.40 & 159 & 2.86 \\
\hline Twitter & & & 2 & 0.07 & 2 & 0.04 \\
\hline Social website & 2 & 0.07 & & & 2 & 0.04 \\
\hline Facebook & & & 1 & 0.04 & 1 & 0.02 \\
\hline
\end{tabular}

Table 7.

Proportion of layers, sectors and conglomerates in the Top 4.

Catalan competitor, Codorníu, with only one domain, barely manages to get 80 URLs ranked in seven of the searches.

There is no brand of cava that appears in the Top4, and in the case of Freixenet, despite the fact that the domain freixenetusa.com has 806 contents ranked in the Top50, its average position is 27.45 on mobile and 25.93 on desktop, which is way 
Cheers in UK: How Visible Are Spanish Sparkling Wines on Google.co.uk?

DOI: http://dx.doi.org/10.5772/intechopen.89541

\begin{tabular}{lcccccc}
\hline Cava brands & $\begin{array}{c}\text { Google.co.uk } \\
\text { Mobile }\end{array}$ & $\begin{array}{c}\text { Average } \\
\text { ranking }\end{array}$ & $\%$ & $\begin{array}{c}\text { Google.co.uk } \\
\text { Universal }\end{array}$ & $\begin{array}{c}\text { Average } \\
\text { ranking }\end{array}$ & $\%$ \\
\hline freixenetusa.com & 406 & 27.45 & 1.12 & 400 & 25.93 & 1.10 \\
\hline freixenet.com & 56 & 43.64 & 0.15 & 68 & 40.21 & 0.19 \\
\hline paresbalta.com & 62 & 33.32 & 0.17 & 59 & 32.07 & 0.16 \\
\hline artcava.com & 58 & 35.79 & 0.16 & 53 & 34.58 & 0.15 \\
\hline freixenet.es & 53 & 34.11 & 0.15 & 55 & 35.22 & 0.15 \\
\hline holacava.com & 44 & 36.66 & 0.12 & 39 & 37.72 & 0.11 \\
\hline codorniu.com & 44 & 40.00 & 0.12 & 36 & 38.58 & 0.10 \\
\hline gonzalezbyass.com & 19 & 43.95 & 0.05 & 46 & 34.26 & 0.13 \\
\hline pinord.com & 30 & 39.13 & 0.08 & 31 & 32.58 & 0.09 \\
\hline freixenet.co.uk & 28 & 45.75 & 0.08 & 30 & 43.33 & 0.08 \\
\hline
\end{tabular}

Table 8.

Cava brands ranked in the Top50.

beneath the top of the SERPs and whose visibility and click probability are almost $0 \%$. It should also be noted that the only specific UK domain, freixenet.co.uk, appears in average positions of 43 and 46 out of 50, with virtually null visibility.

These average URL rankings of the 10 Spanish brands in 25-46th place out of 50 confirm the information published by the RAW agency on the digital behaviour of Spanish wineries, claiming that they have not been launched onto the digital market. This is why we advise these companies to work to get their websites into the Top10 of Google search engines, through SEO optimization or payment for keywords to appear in SEM, and thus achieve greater international visibility for their brands and products, focusing first on the international markets where the company has the highest sales and, secondly, on developing markets where there are good sales prospects.

The third research question asked what media, social networks and wine sites are retrieved by Google when searching for Spanish sparkling wines from the UK and what their weight is.

\subsection{Media visibility}

After performing an analysis of the media that appear in the Top4 Google.co.uk positions (see Table 9 ), we note that $43.86 \%$ correspond to questions that the search engine suggests to users who are looking for information about Spanish cava or sparkling wine.

In a prominent second place, we found the independent.co.uk newspaper, which covers $7.17 \%$ of searches made, followed by the telegraph.co.uk newspaper with $2.3 \%$ and theguardian.com with $1.90 \%$ of results when combining results for its website and the AMP mobile version.

From this analysis, we observed that these Spanish cava companies' marketing plans do not include public relations or advertising actions with these media, since their visibility is very limited.

\subsection{Visibility of social networks}

Regarding the visibility of social networks in searches related to cava or sparkling wine (see Table 10), we should note that only en.wikipedia.org and youtube.com 


\begin{tabular}{lcccccc}
\hline Media & $\begin{array}{c}\text { Google.co.uk } \\
\text { Mobile }\end{array}$ & $\%$ & $\begin{array}{c}\text { Google.co.uk } \\
\text { Universal }\end{array}$ & \% & Total & $\%$ \\
\hline Google-related questions & 1079 & 38.76 & 1363 & 48.96 & 2442 & 43.86 \\
\hline independent.co.uk & 200 & 7.18 & 199 & 7.15 & 399 & 7.17 \\
\hline telegraph.co.uk & 60 & 2.16 & 70 & 2.51 & 130 & 2.33 \\
\hline amp.theguardian.com & 54 & 1.94 & & 0.00 & 54 & 0.97 \\
\hline theguardian.com & 9 & 0.00 & 52 & 1.87 & 52 & 0.93 \\
\hline bloomberg.com & 9 & 0.32 & 8 & 0.29 & 17 & 0.31 \\
\hline thetimes.co.uk & 6 & 0.22 & 5 & 0.29 & 17 & 0.31 \\
\hline thesun.co.uk & 4 & 0.14 & 5 & 0.18 & 11 & 0.20 \\
\hline chicagotribune.com & & 0.00 & 6 & 0.18 & 9 & 0.16 \\
\hline express.co.uk & & & & 0.22 & 6 & 0.11 \\
\hline
\end{tabular}

Table 9.

Results generated by Google and 9 main media websites in the Top 4.

\begin{tabular}{lcccccc}
\hline Social network & Google.co.uk Mobile & $\mathbf{\%}$ & Google.co.uk Universal & \% & Total & $\%$ \\
\hline en.wikipedia.org & 134 & 4.81 & 192 & 6.90 & 326 & 5.85 \\
\hline youtube.com & 120 & 4.31 & 39 & 1.40 & 159 & 2.86 \\
\hline twitter.com & & 0.00 & 2 & 0.07 & 2 & 0.04 \\
\hline eyeonspain.com & 2 & 0.07 & & 0.00 & 2 & 0.04 \\
\hline m.facebook.com & & 0.00 & 1 & 0.04 & 1 & 0.02 \\
\hline
\end{tabular}

Table 10.

Social networks with visibility in the Top4.

\begin{tabular}{lcccccc}
\hline Wine & $\begin{array}{c}\text { Google.co.uk } \\
\text { Mobile }\end{array}$ & $\%$ & $\begin{array}{c}\text { Google.co.uk } \\
\text { Universal }\end{array}$ & \% & Total & $\%$ \\
\hline winefolly.com & 126 & 4.53 & 25 & 0.90 & 151 & 2.71 \\
\hline vinepair.com & 49 & 1.76 & 73 & 2.62 & 122 & 2.19 \\
\hline winepleasures.com & 26 & 0.93 & 28 & 1.01 & 54 & 0.97 \\
\hline vivino.com & 5 & 0.18 & 14 & 0.50 & 19 & 0.34 \\
\hline decanter.com & 9 & 0.32 & 8 & 0.29 & 17 & 0.31 \\
\hline winemag.com & 4 & 0.14 & & 0.00 & 4 & 0.07 \\
\hline wineonline.ie & 1 & 0.04 & 1 & 0.04 & 2 & 0.04 \\
\hline sparklingwinos.com & 2 & 0.07 & & 0.00 & 2 & 0.04 \\
\hline thedrinksbusiness.com & & 0.00 & 1 & 0.04 & 1 & 0.02 \\
\hline spanish-wines.org & 1 & 0.00 & 1 & 0.04 & 1 & 0.02 \\
\hline premierestateswine.co.uk & & 0.04 & & 0.00 & 1 & 0.02 \\
\hline
\end{tabular}

Table 11.

Wine websites in the Top4.

hold any significant weight in the Top4 with 5.85 and 2.86\%, respectively. Other social networks have only marginal visibility, since twitter.com and eyeonspain.com each has two ranked items of content, and m.facebook.com only has one. 
These results suggest that Spanish cava companies do not prioritise communication of their products on the web pages shown in Table 10 and from which they could obtain much better visibility among British users.

\subsection{Visibility of wine sector websites}

As shown in Table 11, the leading wine website in terms of visibility is winefolly.com which accumulates $2.71 \%$ of the total results in the Top4, claiming top spot on Mobile (4.53\%) and coming third in Universal $(0.90 \%)$. The next sites in the global ranking are vinepair.com and winepleasures.com with 2.19 and $0.97 \%$ respectively, although the former site has a greater number of ranked content in the Universal version.

The fourth and final question asks what the main e-commerce websites are in terms of their visibility.

As we mentioned earlier, by mapping websites on the sample of results, we can measure the visibility of any website whose contents are visible on Google SERPs.

\begin{tabular}{|c|c|c|c|c|c|c|}
\hline & $\begin{array}{l}\text { Google.co.uk } \\
\text { Mobile }\end{array}$ & $\%$ & $\begin{array}{c}\text { Google.co.uk } \\
\text { Universal }\end{array}$ & $\%$ & Total & $\%$ \\
\hline Amazon & 22 & 0.79 & 19 & 0.68 & 41 & 0.74 \\
\hline amazon.co.uk & 22 & 0.79 & 19 & 0.68 & 41 & 0.74 \\
\hline Supermarket & 258 & 9.27 & 199 & 7.15 & 457 & 8.21 \\
\hline tesco.com & 63 & 2.26 & 99 & 3.56 & 162 & 2.91 \\
\hline groceries.morrisons.com & 94 & 3.38 & 50 & 1.80 & 144 & 2.59 \\
\hline groceries.asda.com & 30 & 1.08 & 27 & 0.97 & 57 & 1.02 \\
\hline m.tesco.com & 48 & 1.72 & & 0.00 & 48 & 0.86 \\
\hline bascofinefoods.com & 22 & 0.79 & 21 & 0.75 & 43 & 0.77 \\
\hline marksandspencer.com & 20 & 0.72 & 18 & 0.65 & 38 & 0.68 \\
\hline sainsburys.co.uk & 2 & 0.07 & 3 & 0.11 & 5 & 0.09 \\
\hline aldi.co.uk & 1 & 0.04 & 2 & 0.07 & 3 & 0.05 \\
\hline simplespanishfood.typepad.com & 1 & 0.04 & & 0.00 & 1 & 0.02 \\
\hline Spirits & 129 & 4.63 & 91 & 3.27 & 220 & 3.95 \\
\hline laithwaites.co.uk & 42 & 1.51 & 33 & 1.19 & 75 & 1.35 \\
\hline totalwine.com & 30 & 1.08 & 24 & 0.86 & 54 & 0.97 \\
\hline matthewclark.co.uk & 15 & 0.54 & 16 & 0.57 & 31 & 0.56 \\
\hline waitrose.com & 30 & 1.08 & & 0.00 & 30 & 0.54 \\
\hline gerrardseel.co.uk & 5 & 0.18 & 8 & 0.29 & 13 & 0.23 \\
\hline sundaytimeswineclub.co.uk & 2 & 0.07 & 2 & 0.07 & 4 & 0.07 \\
\hline decantalo.com & 1 & 0.04 & 2 & 0.07 & 3 & 0.05 \\
\hline majestic.co.uk & 1 & 0.04 & 2 & 0.07 & 3 & 0.05 \\
\hline enterwine.com & & & 3 & 0.11 & 3 & 0.05 \\
\hline sedimentality.com & 2 & 0.01 & & 0.00 & 2 & 0.04 \\
\hline waitrosecellar.com & 1 & 0.00 & & 0.00 & 1 & 0.02 \\
\hline thechampagnecompany.com & & & 1 & 0.04 & 1 & 0.02 \\
\hline
\end{tabular}

Table 12.

E-commerce sites that appeared in the Top4 positions of Google.co.uk. 
The database resulting from this mapping procedure includes a series of e-commerce sites that we classified into three different conglomerates based on the products offered. So, we have a first conglomerate where all the results from Ama zon.co.uk were grouped, a specific conglomerate of supermarkets with visibility in the Top4, and a third for e-commerce websites specialising in wines and spirits.

Table 12 shows all the e-commerce websites that appeared in the sample grouped into the three aforementioned conglomerates.

The analysis also shows that the e-commerce domain that appears most frequently and has the best SEO rankings is tesco.com, as it appears 210 times (3.77\%); in second place is groceries.morrison.com with 144 URLs, followed by the laithwa ites.co.uk wine store with 75 URLs and groceries.asda.com with 57, while Amazon. co.uk appears seventh with 48 URLs ranked in the Top4. It should also be noted that the m.tesco.com link appears 48 times and sends users directly to the supermarket's wine section.

\section{Conclusions}

In this chapter, we have quantified a representative set of queries related to sparkling wine used by British users when searching for information on Google. From this set of queries, we have selected the ones that are directly linked to cava and extracted search engine results for a 29-week period so as to generate a database of all visible websites on Google.co.uk when searching for Spanish sparkling wines, among which we have identified the websites of Spanish brands.

Using the Google Ads Keyword Planner instrument, we retrieved the monthly frequency of a set of queries related to sparkling wine that include the generic term 'sparkling', the word 'cava', or the names of its direct competitors, namely 'champagne' and 'prosecco'.

From analysing this frequency data, we could confirm the rising tendency of the term 'prosecco', which is the most in-demand sparkling wine on international markets and the one that accumulates the highest number of queries in the UK; we also confirm the hegemony of 'champagne', which accumulates the highest number of searches a month, with searches for 'cava' and 'sparkling wine' in third and fourth place.

After this initial analysis, a set of 24 keywords related to Spanish sparkling wine were selected and SEO techniques were applied to extract the URLs that are shown when British users search using these keywords. The result was a sample of URLs and websites with which we could map all the websites that are visible on Google. co.uk for searches on subjects related to Spanish cava or sparkling wines.

Based on this mapping of results from Google.co.uk, we performed a cybermetric analysis of the web domains to work out the visibility of any website associated with the Spanish sparkling wine niche, and in particular to quantify the visibility of Spanish brands on SERPs.

This is how we were able to measure the visibility of the websites of Spanish sparkling wine brands, noting that no cava brand is ranked in the Top4, and that the site with the highest visibility, freixenetusa.com, reaches an average ranking of 25, a position with a visibility and click probability of almost $0 \%$. On average, the 10 Spanish brands detected in the sample are in around 25th and 46th place, which confirms the data published by the RAW agency that claims that these brands have not been launched on the digital market.

Likewise, all the web contents that appear in the results have been identified, especially those belonging to the media, social networks, wine websites and e-commerce sites. These data can be used as the basis to suggest content strategies 
that will gain visibility in the search niche, and offer guidance on where Spanish brands should focus in order to increase their visibility among British users and overcome barriers for the sale of wine.

Finally, we should stress that the mapping of websites in the sector shows what contents are chosen by the Google algorithm from among thousands of possible candidate sites. This selection showcases the best contents that any winery should take into account when creating their digital identity.

As a final conclusion, we could comment that if Google's Consumer Barometer mentions that 'By understanding what consumers look for, businesses are able to ensure the right information is available on their websites', by understanding what results appear on Google, we can make the contents available on cava websites visible from any search engine.

\section{Implications for managers}

The managerial applications derived from this study are aimed at improving the marketing strategies of Spanish wineries. The results of the research can help to optimise a company's digital identity and lead to a variety of actions aimed at improving not only the visibility of its website but also sales of products.

The following are four particular actions derived from this study whose real application will help to boost the ranking of cava brands and products.

Our first recommended action is to improve SEO strategies, that is, optimise websites to position their contents at the top of SERPs and thus achieve greater international visibility for brands and products. Brands should first focus on the international markets where the company has the highest sales and secondly, on developing markets where there are good sales prospects.

The second action is aimed at improving knowledge about consumers through search engine analysis. On the one hand, quantitative analysis of the frequency of Google queries related to cava, champagne and prosecco can be used to measure the level of relative and absolute interest in these three products that compete not only in the British market but also on a global scale. On the other hand, qualitative analysis of long-tail queries offers specific details about the perception of cava, prosecco and champagne among the population of any country.

The third action is directly related to improved website visibility, as knowledge of the ranking and level of optimisation of a website can reveal whether the content marketing plan is working in a certain market. That is why this third action is based on finding out what types of content are preferred by Google, which will help us to develop optimised content strategies based on the data extracted from the sample.

In the case of cava, it has been detected that independent.co.uk, telegraph.co.uk and theguardian.com are the press websites that cava brands should focus their public relations, advertising and press releases on, since they are the sites that can capture the most organic traffic for searches related to cava. Likewise, the social networks that have been identified as having the greatest visibility in British results, and for which we advise companies to develop good content, are Wikipedia, YouTube, Twitter and Facebook; to feature on the wine websites with the highest visibility in the UK, they should target efforts on winefolly.com, vinepair.com and winepleasures.com, and negotiate linear marketing and promotional deals with the leading e-commerce sites, particularly tesco.com, groceries.morrison.com, laithwa ites.co.uk, groceries.asda.com and totalwine.com, as these will not only take charge of selling the products, but also advertise and promote the brands and products that they work with on their own web pages. Knowledge of these media, blogs, websites and e-commerce companies will help to plan content, advertising and 
branded-content strategies to achieve better brand and product visibility in the eyes of British netizens.

In conclusion, we are able to make recommendations to improve the digital identity of cava brands aiming to gain visibility in a specific market.

\section{Limitations}

This study is not free of limitations. First, the selection of a single national search engine tells us about the visibility of Spanish sparkling wine sites in that specific country, but the results cannot be extrapolated to markets other than the UK. Secondly, although the AWR instrument can be used to select IPs from a specific country, the personalization of Google results based on the user's location can cause variations in the rankings and proportions of results for the same search. It would therefore be advisable to perform the data extractions from different locations in the UK and compare the results. Thirdly, constant modifications to Google's ranking algorithms can cause considerable variations in the results, so this study is only valid in the short or medium term. Therefore, the recommendations derived from these analyses need to be adjusted to further monitoring of the Google rankings over time in order to cater for evolutions in terms of results.

\section{Future lines of research}

Future research derived from this study includes increasing the sample size by expanding the list of analysed terms and/or analysing a higher number of locations.

This study was conducted on the basis of a limited group of searches, that is, a set of keywords limited to 24 generic terms related to cava and Spanish sparkling wine. However we could expand the list of terms in different ways by adding new combinations of keywords belonging to the same semantic field.

For example, we could add new generic searches related to the different types of cava and their variants ('cava' + 'type of grape' / 'cava' + DO / 'cava' + 'brand' / 'cava' + 'name of supermarket', 'cava' + 'search transaction modifiers') and measure the exact, real-time visibility of Catalan sparkling wine brands in Google results viewed from the UK or from any other country. Another option would be to use a set of keywords that includes terms related to wine tourism in Spain, which would allow us to measure the visibility, from any country in the world, of websites selling trips to Spanish vineyards.

The exercise could also be replicated with new sets of keywords using generic searches related to 'champagne' and 'prosecco', in order to measure the visibility of Italian and French wineries in the UK or on any other search engine.

As well as keywords, we could also increase the number of locations in the UK in order to measure deviations from this data capture, or choose any other Spanish wine-buying market by selecting different Google search engines designed for specific countries or cities.

Also, and in a similar way to what the SEMrush instrument does, at present we can only estimate the traffic from Google.co.uk to Spanish wineries in terms of the amount of content that appears on SERPs and their position. In future research, it will be essential to contrast visibility on Google.co.uk with the real traffic data of Spanish sparkling wine sites. Doing so would necessarily require traffic data on Spanish wineries obtained by accessing the Google Analytics platform of the different websites. 
In the long term, with a large database both of terms and sector websites, an observatory of the wine search niche focused on measuring Spanish websites in potential importer countries could be created.

\section{Acknowledgements}

This research has been carried out under the project eMarketwine (CSO2016-78775-R), financed by the Spanish Minister of Economy.

\section{Author details}

Carlos Gonzalo-Penela ${ }^{1}$, Noelia Jiménez-Asenjo ${ }^{2}$ and Diana A. Filipescu ${ }^{3 *}$

1 Pompeu Fabra Univeristy, Barcelona, Spain

2 EAE Business School, Barcelona, Spain

3 Toulouse Business School, Barcelona, Spain

*Address all correspondence to: d.filipescu@tbs-education.es

\section{IntechOpen}

(C) 2019 The Author(s). Licensee IntechOpen. This chapter is distributed under the terms of the Creative Commons Attribution License (http://creativecommons.org/licenses/ by/3.0), which permits unrestricted use, distribution, and reproduction in any medium, provided the original work is properly cited. (c) BY 


\section{References}

[1] Bernetti I, Casini L, Marinelli N. Wine and globalisation: Changes in the international market structure and the position of Italy. British Food Journal. 2006;108(4):306-315

[2] Nosi C. Il vino fra produzione e mercato. Catanzaro: Rubbettino Università; 2012, 169 p. (Not found in Google academic)

[3] OIV. Global State of Conditions Report: Developments and Trends. April 2018. International Organisation of Vine and Wine. 2018. Available from: http://www.oiv.int/en/oiv-life/globalstate-of-conditions-reportdevelopments-and-trends-april-2018

[4] IWSR. The IWSR Vinexpo Report 2011-2021. 2018. Available from: https://www.theiwsr.com/iwsr_ vinexpo_report.html

[5] IWSR. The IWSR Vinexpo Report 2012-2022. 2019. Available from: https://www.theiwsr.com/iwsr_vine xpo_report.html

[6] Statista. Volume of Sparkling Wine Imports to the United Kingdom (UK) in 2015. 2018a. Available from: https:// www.statista.com/statistics/ 706275/volume-of-sparklingwine-imports-united-kingdom-uk/

[7] Statista. Market Share Held by the Leading Search Engines in the United Kingdom (UK) as of November 2018. 2018b. Available from: https://www. statista.com/statistics/280269/marketshare-held-by-search-engines-inthe-united-kingdom/

[8] Jiménez-Asenjo N, Filipescu DA. Cheers in China: International marketing strategies of Spanish wine exporters. International Business Review. 2019;28(4):647-659

[9] Comportamiento digital de las bodegas en España - Agencia RAW.
Available from: < https://www.agencia raw.com/lab/bodegas/\#slide=1 $>$

[10] Nielsen RK. News media, search engines and social networking sites as varieties of online gatekeepers. In: Rethinking Journalism Again. Routledge; 2016. pp. 93-108. Available from: https://www.taylorfrancis.com/ books/e/9781315716244/chapters/ 10.4324/9781315716244-12

[11] Slawski B. Seobythesea. How Google Universal and Blended Results May Work. 2008. Available from: http:// www.seobythesea.com/2008/06/howg oogle-universal-search-and-blendedresults-may-work/

[12] Singhal A. Introducing the Knowledge Graph: Things, Not Strings. Google Official Blog. 2012. Available from: https://googleblog.blogspot.com/ 2012/05/introducing-knowledgegraph-things-not.html

[13] Maynes R. MOZ blog, Eye Tracking in 2014: How Users View \& Interact with Google SERPs. 2014. Available from: https://moz.com/blog/eyetracking-in-2014-how-users-viewand-interact-with-todays-google-serps

[14] Peretti J. Culture Jamming, Memes, Social Networks, and the Emerging Media Ecology the "Nike Sweatshop Email" as Object-to-Think-with. 2003. University of Washington. Available from: http://depts.washington.edu/ccce/ polcommcampaigns/peretti.html

[15] Bennett WL. Political Communication, Citizenship and Democracy: From the Mass Society to Personal Information Networks. Presentation slide show distributed by autor; 2004

[16] Gonzalo-Penela, Carlos. (2015). Posicionamiento web y dinámicas de información en motores de búsqueda: 
Cheers in UK: How Visible Are Spanish Sparkling Wines on Google.co.uk? DOI: http://dx.doi.org/10.5772/intechopen.89541

propuestas de análisis y estudio comparativo de visibilidad de contenidos digitales en el caso de procesos electorales [doctoral thesis]. Barcelona: UPF; 2015. Available from: http://hdl.handle.net/10230/23621 



\title{
Chapter 6
}

\section{Digital Marketing: Scope Opportunities and Challenges}

\author{
Chandan Kumar Mishra
}

\begin{abstract}
With the onset of Internet reform and economic growth of country, consumer expectation and need have formed a shape where comfort and delight service has become vital criteria for product selection. Several brands in market keep working to evaluate the changing need of consumers, developing suitable product and finding market place to reach the right customer. This digital reform has paved a new marketplace on Internet where everything and anything is available to explore and review and have a virtual feel. India is a growing economy country and has been considered in the article to brief the concept and scenario of different trends of digital marketing. The article will bring insights into the scope of different digital trends and future scope. In the 2019 summit of United Nations, leaders spoke about borderless economy reforms connecting new business players to invest in growing economy country. Here, to bring borderless and seamless economy, digital platform will play a major role for entry player as well as big MNCs evaluated in the need section of digital marketing. This article has referred collective researches and survey inputs from various sources and used secondary data mixed methods, keeping it unique and best suited for students to capture many new terminologies of digital marketing and bring utmost clarity on future trends of digitalisation. Agricultural segment has been studied in brief in correlation with digital marketing. This article refers to study on digital marketing suiting current need of people limited to its optimum and safe usage of Internet, considered as one of basic rights of human kind in twenty-first century.
\end{abstract}

Keywords: scope and challenges of digital marketing, future trends of digital marketing and its scope in agricultural segment

\section{Marketing}

Marketing is the oldest science with the human beings of identifying, creating, exchanging need and relationships between seller and buyer at a profit, thereby promoting and enabling the process of trading product or service. Definition of marketing as explained by Dr Philip Kotler, states it as "Satisfying needs and wants through an exchange process", the marketing is the broader way to reach customer which involves selling as the prime cause been influenced through different steps like need understanding, brand recognition and thereby completing element of sales and purchase. This includes different key process such as Need Identificationproduct development-customer reach and retention with loyalty building-need fulfilment. Following these each process gives sustainable market for marketer [1]. 
Connect to create and enabling reach of product and service from concept to customer is the base line in Marketing. In twenty-first century, approach of marketing has evolved opting digital form where product and brand is made to reach customer mind and influencing decisions through different tactics opted by brands. [1] This digital approach evolution of service marketing mix becomes more customer focus and new products made keeping Customer in centre. Thus 7 C's becomes more useful rather than 7 P's which reimagine the 7 P's in customerfocussed manner as mention Product-Customer, Price-Cost, Place-Convenience, Promotion-Communication, People-Caring, Process-Coordination, Physical Evidence-Confirmation [1].

The promotion of service or product to be deliverable is necessary to reach its people and there are various ways of promotion to increase awareness, generate sales and brand loyalty, develop interest and curiosity among buyers.

With the industrial reformation, the need of fast and impactful marketing is in demand and the technological advancement has changed the way of reaching to customer. Many advertisers/industries are using search engines to promote their businesses. The journey of paper writing to blog has been much faster and trends of marketing has shown paradigm shift in last 5 years than in last 50 . Ease of access to internet is now trending from $2 \mathrm{G}$ to $4 \mathrm{G} / 5 \mathrm{G}$ and this has become base for new era on which different products are placed and explored on Internet. The online marketing is now an ever-growing industry [2].

\section{Need of digitalisation}

Digitalisation has played a crucial role in the fast advancement of global economy. In developed markets, Digital market is one of the most prominent and established platform. Organised digitalisation has a $75-80 \%$ share in total marketing as compared with developing economies, where BTL marketing activities has a dominant share [3].

There is a local say "Be there where your customer Are" and digitalisation is enabling brand to remain where current customers stay i.e., in social mediaFacebook, Twitter, YouTube, Instagram. Digitalisation is maintaining its impressive growth in all markets, whether big or small. Big markets are countries that are always going to be e-commerce behemoths because of their size, and the smaller are promising markets where potential matters along with size (though not always).

Recent verdict in high court of Kerala, consider Right to Internet as fundamental freedom and is a part of Right to education for mankind. In 2019, there are 1.92 billion online buyers in world, accounting for a quarter of world population with 4.39 billion users on Internet and 3.48 billion users active on social media with increase of 9\% YOY. In 2014, online buyers were at 1.32 B expected to touch 2.14 billion by 2021, and over the next 5 years growth is expected to grow $21 \%$. India, with world's second highest population, is a developing country where 627 million users are active on Internet with active buying at 273 million and with a growth rate of $20 \%$ increase for online buyers [4].

Digitalisation has become very decisive platform for the product and brand.

\section{Scenario in developing countries: India and South East Asia}

\subsection{The information revolution}

The spread of mobile and other means of information technology has been truly pervasive in India. Having a population of 1.3 billion, India has 970 million number 
of active mobile phone connections. Since 2000, there has been exponential growth in the number of cell phone users in India (see Figures 1 and 2) [5].

It is also estimated that by 2019, there will be about 299 million smartphones in India as compared to 140 million in 2014. Low cost smart phones running on low cost operating system like Android One are fuelling the rise of smartphones in India. It is also estimated that there will be 527 million total Internet users in 2018, up from

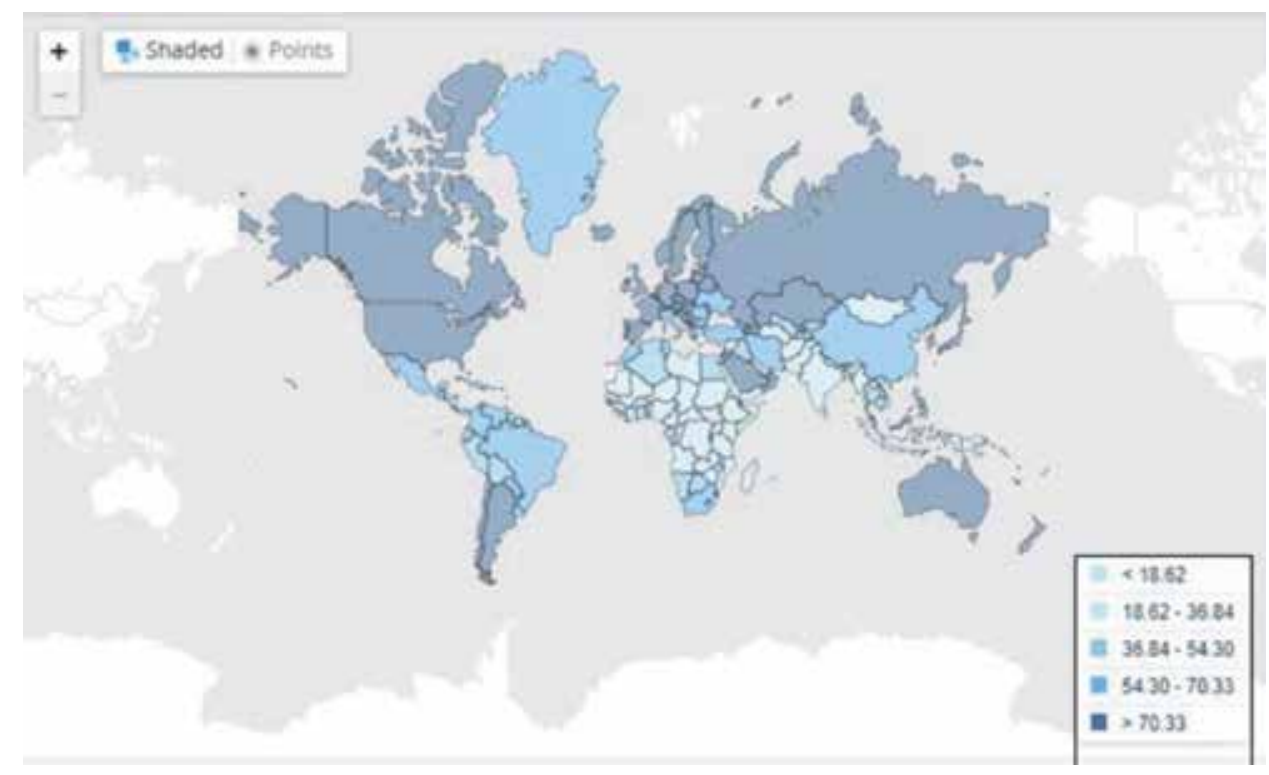

Figure 1.

Individuals using the Internet. Source: International Telecommunication Union, World Telecommunication/ ICT Development Report and database.

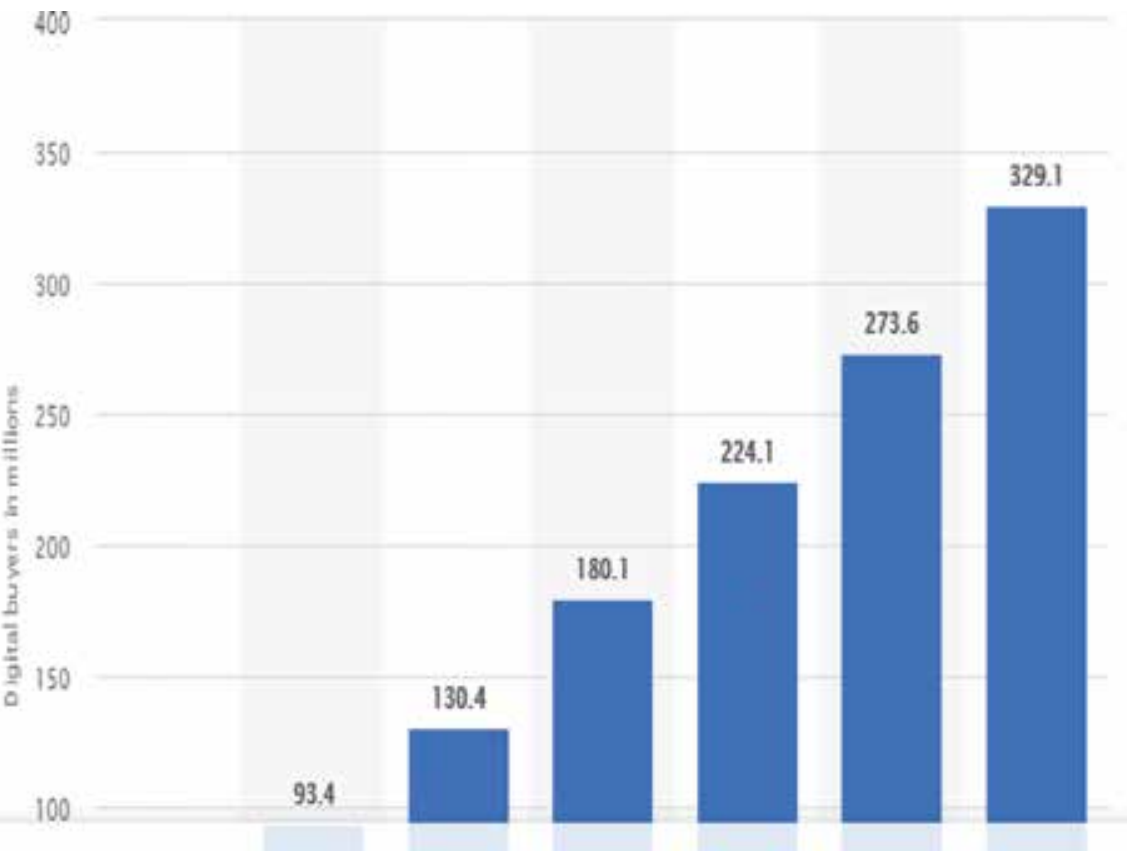

Figure 2.

Digital Buyers in India 2014-2020. Source: Published by Statista Research Department, August 15, 2016. 


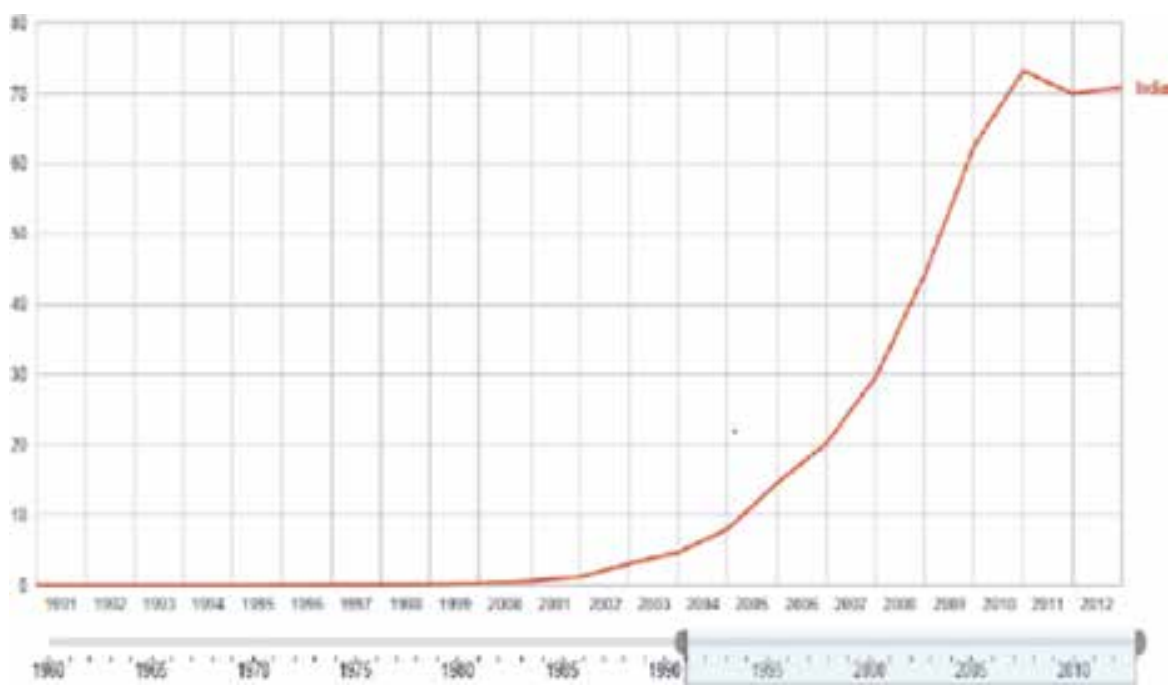

Figure 3.

Mobile cellular subscription per 100 people in India. Source: Data from World Bank.

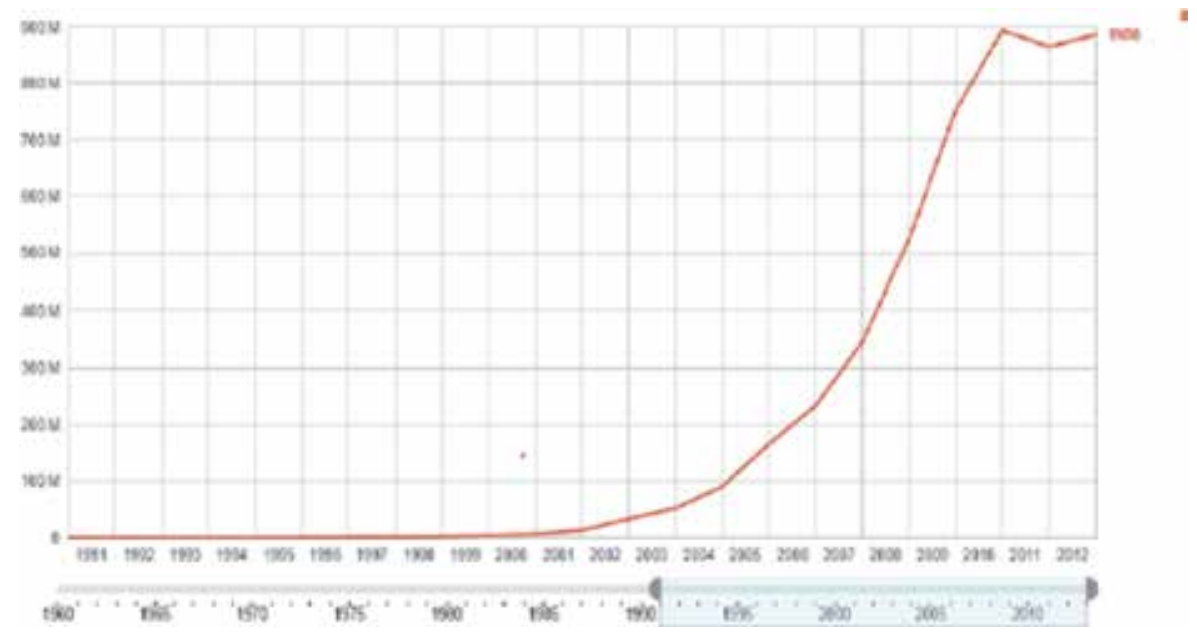

Figure 4.

Rise of total mobile subscription in India. Source: Data from World Bank.

213 million in 2013. Thereby given their reach, the combination of mobile and internet technologies has the potential of engaging a billion people in India [5] (Figures 3 and 4).

\section{Change in consumer behaviour}

Today's consumer is tech savvy, socially empowered, information rich and lacking time. At the same time, technology is quickly evolving and embracing the needs resulted from new consumer motivations. Consumers' ability to influence fellow consumers and companies alike is much bigger than earlier generations [2].

As a result, consumers expect the world at their fingertips, when they want it, how they want it and where they want it. Shopping is not a planned destination or 
event-they are shopping, 24/7. And they want an authentic shopping experience tailor-made specifically for them.

'Generation Z', want it all. They want to make an impact to the world and share all of their experiences on their journey. They strive to be authentic, socially sensible and in many cases value purpose over cost. They are driven by ambition and a strong moral conscience. They strive to independency, are more vocal and more informed than any generation before them. They are cognizant, engaged and choosy. They expect these standards are met by the businesses with which they deal with or take their business elsewhere. Furthermore, they will express their opinion, available for other fellow consumers to read.

With the onset of 1990s, Indian politics has seen digital changes where computerization and digitalisation invited by political leaders. Telecom revolution and IT revolution was started by the then prime minister of India Late Mr Rajiv Gandhi, which paved the way for many global players to enter the Indian economy. These companies saw India as a big opportunity and rushed to cater to middle class consumers - an estimated people of 200 million. India became biggest consumer of world for most industry section and responded to world market at double pace to see economy boosting. This elevated again with the launch of mobile at cheapest rate bringing mobile revolution in 2000 and Internet revolution by Jio in 2017 in India. These two steps paved India to see the world in similar specs as developed countries are seen bringing global market on tips. India with its strong growing GDP around $8 \%$ bring sustained market place for big MNCs, Although, current GDP rate reduced to $6.6 \%$ due to several recent government policies like demonetisation and GST implementation, country is focussed to see $\$ 5$ trillion economy which is boosting global MNCs to cater Indian market. Beside economy, India stood first with highest youth population of world making country biggest market place and prominence to accept digital market [6].

\subsection{Indians are getting more materialistic}

Indians are often stereotyped as deeply spiritual people who reject materialistic values. But this stereotype no longer reflects reality.

Indians have their mark globally and preferred for their dedicated and hard work. They are now motivated to grow and elevate globally to receive factual and material success. Average workweek of $50 \mathrm{~h}$ makes India hardest working nations globally (average workweek in US is $42 \mathrm{~h}$; European nations have workweeks of fewer than $40 \mathrm{~h}$ ). These materialistic characters bring nation close to keep youth busy and demand for easy and fast life. Digital sense became key and focussed on requirement by mass [7].

\subsection{Consumerism is becoming a way of life in India}

A study on Indians' savings goals reveals the increase in materialism. Savings and property making for next generation is long term priority, life's pleasure and status symbolism have gained importance in last decades keeping growth in tendency for Indians money aside for electronics and smart gadgets (Figures 5 and 6).

Digital marketing accounts a new way to promote products thereby wholesale and retail industry are largely affected with its implementation. Reference to ICRIER (Indian Council for Research and International Economic Relations), retail market accounts to $10 \%$ of India's GDP. It is sparked with increasing footfall of customer base, rising Indian economy, fast face life of youth, adoption of change in lifestyles and growing concept of Make in India. Organised retail sector is likely to have growth rate near to $45-50 \%$ p.a. and booming further with adoption of digital technology. 


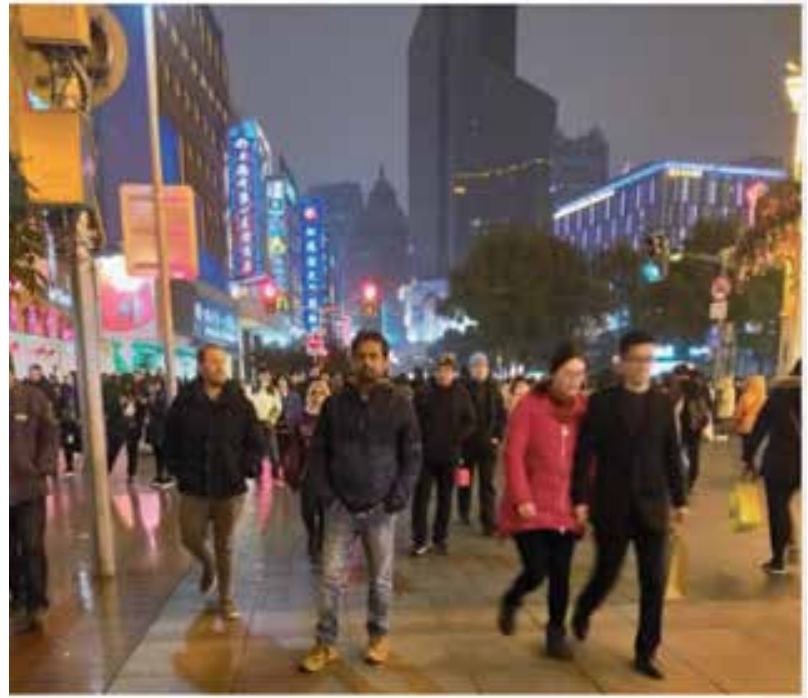

Figure 5.

People investing on commercial and market development. Source: Original.

\section{Savings Goals}

bencencagt of indiers who isenested (hele $x$ ambeg ther coula?

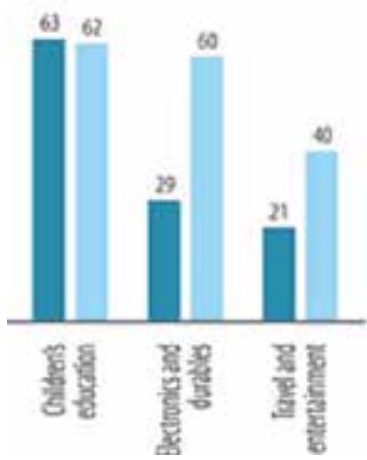

\section{Durable Goods Purchases}

cercenage of lintuns who own or vide

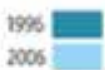

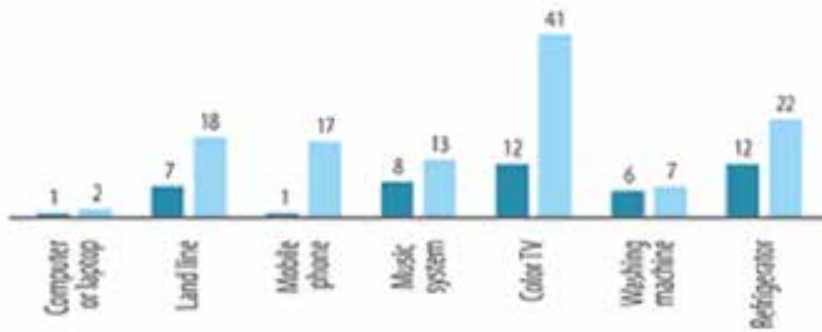

Figure 6.

Changes in consumer behaviour.

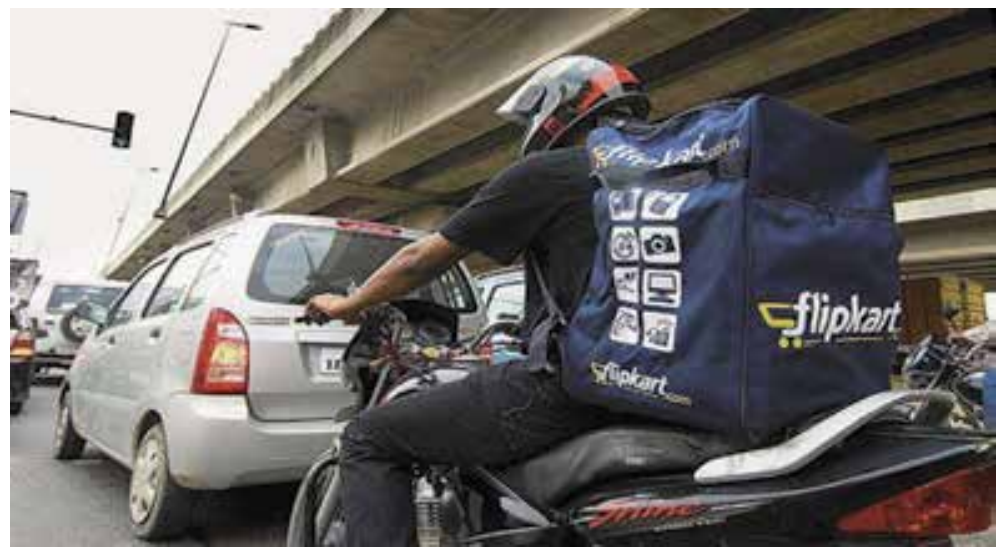

Figure 7.

A man with e-commerce goods for delivery. 
In country like India where population is more than $130 \mathrm{Cr}$ has online penetration to a tune of $60 \%$ and it brings challenge to have immediate shift of traditional retail channel to get embrace with Internet as alternative media to promote product.

However, the growth patterns are impressive for India's digital e-commerce, which has exponentially increased in recent years. It rose by more than $600 \%$, reaching \$16 billion mark in 2014 from $\$ 2.5$ billion in 2009 [7]. With flooding of digital e-commerce firms like Flipkart, Snapdeal, and Amazon in the country, the small and medium physical retailers were affected and suffered a lot. This dramatic change from physical retail to online retail benefitted the consumer bringing big firms and brands to think bringing their presence in the digital world to be connected to these new segments of consumers (Figure 7).

\section{History of digital marketing}

In late 1900, marketing has seen adopting technology and it evolved to make marketing and technology inseparable. This has brought the concept of digital marketing through various steps of events mentioned below (Table 1).

\begin{tabular}{ll}
\hline \multicolumn{2}{l}{ Important events in digital marketing } \\
\hline $\begin{array}{l}1945- \\
1970\end{array}$ & $\begin{array}{l}\text { Idea contemplates for linked documents by Vannevar Bush along with adopting Net by } \\
\text { Computer Science departments in US universities }\end{array}$ \\
\hline $\begin{array}{l}1971- \\
1980\end{array}$ & Bob Metcalfe writes his thesis on Ethernet, Apple II personal computer series introduced \\
\hline $1981-$ & $\begin{array}{l}\text { IBM launched its first computer, ANSI adopted SQL as a standard and also } 100 \mathrm{MB} \\
\text { capacities seen in computer storage }\end{array}$ \\
\hline 1990 & First coined digital marketing, Archie launched first search engine \\
\hline $\begin{array}{l}1993- \\
2001\end{array}$ & $\begin{array}{l}\text { Seen first Web Ad banner, e-commerce transaction started, launch of Yahoo, birth of } \\
\text { Google, first mobile marketing campaign started by Universal Music }\end{array}$ \\
\hline 2010 & $\begin{array}{l}\text { Launch of LinkedIn, Go Live of Facebook, YouTube, Twitter, WhatsApp, Google Buzz, } \\
\text { Amazon sales seen } \$ 10 \text { billion sales, iPhone series launch, China overtakes US on count of } \\
\text { internet users }\end{array}$ \\
\hline $\begin{array}{l}\text { 2011- } \\
2015\end{array}$ & $\begin{array}{l}\text { Social media budgets up 64\%, Facebook takeover WhatsApp, mobile internet users exceed } \\
\text { PC, Snapchat launches discover feature }\end{array}$ \\
\hline $\begin{array}{l}\text { 2016- } \\
\text { today }\end{array}$ & $\begin{array}{l}\text { India seen a big move on Internet Go Live with the launch of JIO, ever highest user login in } \\
\text { Source: Digital Marketing Insights 2019. }\end{array}$ \\
\hline
\end{tabular}

Table 1.

History and evolution of digital marketing.

\section{Digital marketing}

Digital marketing is a non-conventional virtual platform basically on Internet for promoting products, services, connecting customers, identifying and understanding needs of user using digital technologies and devices. It is one of most effective and prominent strategy to promote business online for brand awareness and business development.

The base line of digital marketing is to have individual Website or App through which different promotion and tools are linked and used. Digital marketing is the best approach to reach target audience in cost effective manner and is easier to scale the 
business on faster rate. In current scenario average user with internet spends $3 \mathrm{~h}$ on internet platform daily and it makes it biggest platform to promote any brands to eye catch user or buyer. There is a strong proverb in Hindi "Ants find the sweetness in room kept anywhere" hold good in case of digital marketing, wherever marketer find the right customer with the different tactics through digital marketing be it click type or search engines. It is found in several researches, $85 \%$ search happens before purchase, in $1 \mathrm{~s}$ almost 84 + thousand viewers' remains online in YouTube, and currently $89 \%$ users purchase based on available reviews and comments made for respective products. The young generation even kids are now tech savvy and since very early stage they know to operate smart devices and are fond of accepting technology [9] (Figure 8).

In order to have sustained product below journey need to be followed by the marketer for his product. These all steps are achieved by different tools of digital marketing (Figure 9).

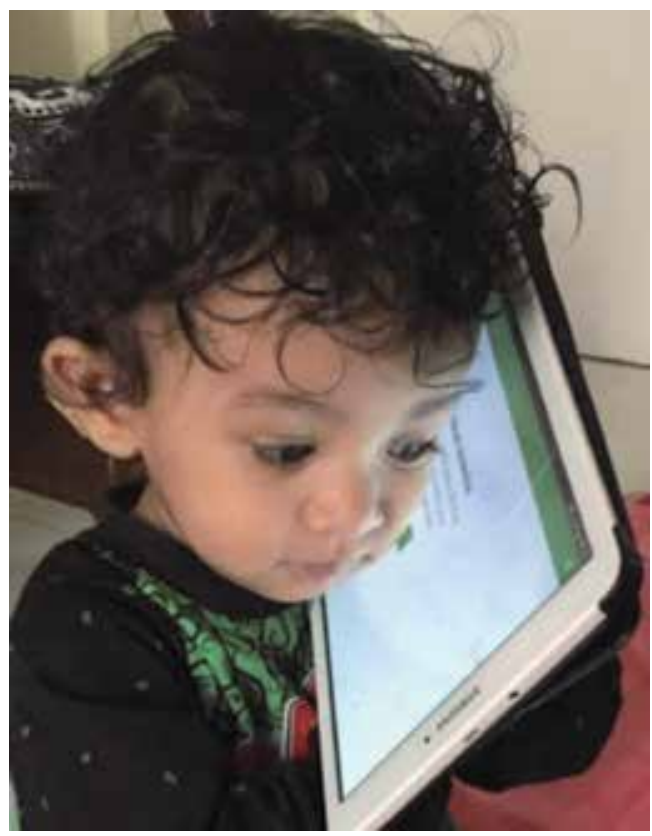

Figure 8.

A 1-year-old child with Tab in his hand: realm of digitalisation. Source: Original.

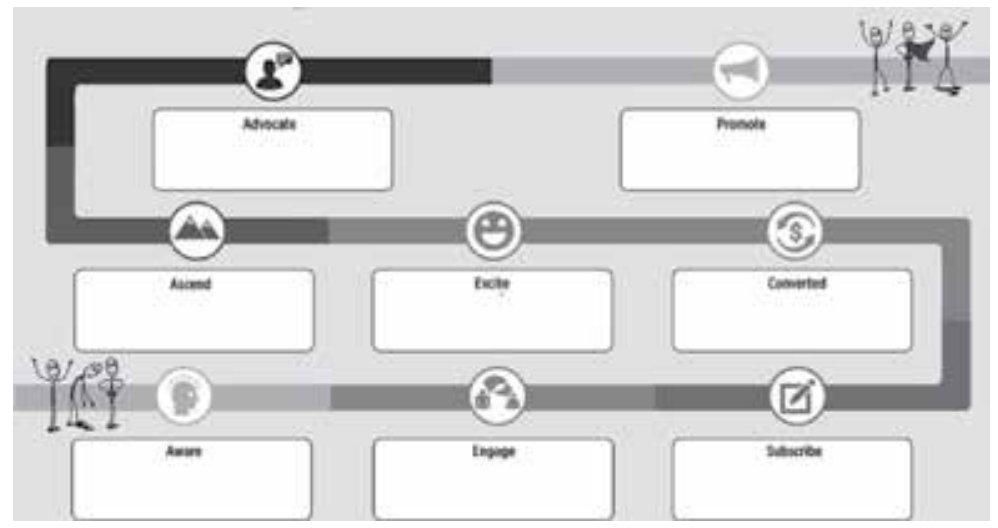

Figure 9.

Customer journey worksheet. Source: Courtesy of The Launch Grid (Digital Marketer). 


\section{Channels of digital marketing}

Digital marketing is incorporated by different brands through various channels suiting their product and means of communicating to their buyers. It also depends on choosing best channels that give better ROI for brand. Most used channels of digital marketing are briefed below [8]:

1. Affiliate marketing: It is perceived as a tool to produce demanded number of customers through independent marketer. It allows the brand to market its product through websites, create traffic and publish information. Individual work on behalf of brand using different tools of digital and leveraging devices. This concept is also popularly known as website marketing where commission to marketer is received only on the sale of a product.

2. Display advertising: It is one of the concepts to use the display organic to attract traffic like used by Google AdWords. Through this small banner, gif images and videos are made to highlight the product or brands. It is one of effect method of digital marketing where visual effect made to eye catch the traffic.

3. Email marketing: This tool is used to communicate to the individual where the promoter is aware about the intender or buyer and communicate directly. This is one of the cheapest modes of marketing and need to ensure effective content drafting. This email marketing is sometime less preferred as the user gets irritated as spam email so the user interest is legal obligation to receive, unsubscribing leads to stop receiving such communications.

4. Search engine marketing: It is a form of internet marketing based on websites. It is one of paid digital marketing concept through which traffic from search engine are brought to product or brand owing business websites. Search engine marketing platforms are Google AdWords, Bing Ads, Yahoo search Ads [8].

5. Search engine optimization: Marketers use different factors and tactics to bring the website to achieve top ranks on organic search results through optimization of search engine. It is based on algorithm and content drafting through which the search are made to attract the traffic of business websites to the top of search engine.

6. Social media marketing: It refers to the process of gaining traffic through social media sites. Paid marketing also commonly known as social media marketing includes promotion of content, websites or products through ads in several mobile apps, trusted and established channels like Facebook, Twitter, Instagram, YouTube, Pinterest, Google+ etc. It is process of advertising on external social sites executed to draw attention of buyers. It is also based on remarketing activities like user, buyers visiting to buy products in Flipkart happens in a way like Flipkart ads follows him even when user is visiting Facebook, Yahoo, Rediff or so similar another social media platform [8].

7.Apps marketing: Promotion of brands in different apps is a new way of promoting products. There are different apps been built for various sections of human livelihood and finding spaces in between or on the app section is the better to reach specific and defined segment. Product related to specific app are also mapped and tie up done by brand so as persons using app are 
considered to have interest in app related products. To put this as an example, people using health app may be interested in buying health products and so any app promotion of protein products could be interested in segment of people using health apps.

8. Web analytics: It is the process of analysing the behaviour of traffic on websites and search engines through measures are decided which will promote and attract more traffic. It is the analysing part of digital traffic through which human behaviour on platform are studied, used for researches so that more valued concept are brought suiting traffic. There are two common categories: onsite and offsite web analytics.

Other frequent used digital marketing channels are like Pay per click, Pop-up Ads, Match content ads, Floating Ads, Interstitial Ads, Online classified Ads, Frame Ads, Banners Ads.

\section{Digital marketing in agricultural industry: India and world}

India contributes to $18 \%$ of world population and ranks seconds by population. More than $60 \%$ of population dependent on agriculture in India contributing $17 \%$ of India GDP, giving jobs to $53 \%$ Indians. This sector is considered unorganised and tapped with many intermediaries due to which farmers has to sacrifice profits, this leads to necessitate removing middle men thereby bringing concept of Farm to Consumer (F2C). Agriculture has seen phases of changes as shown (Figures 10 and 11).

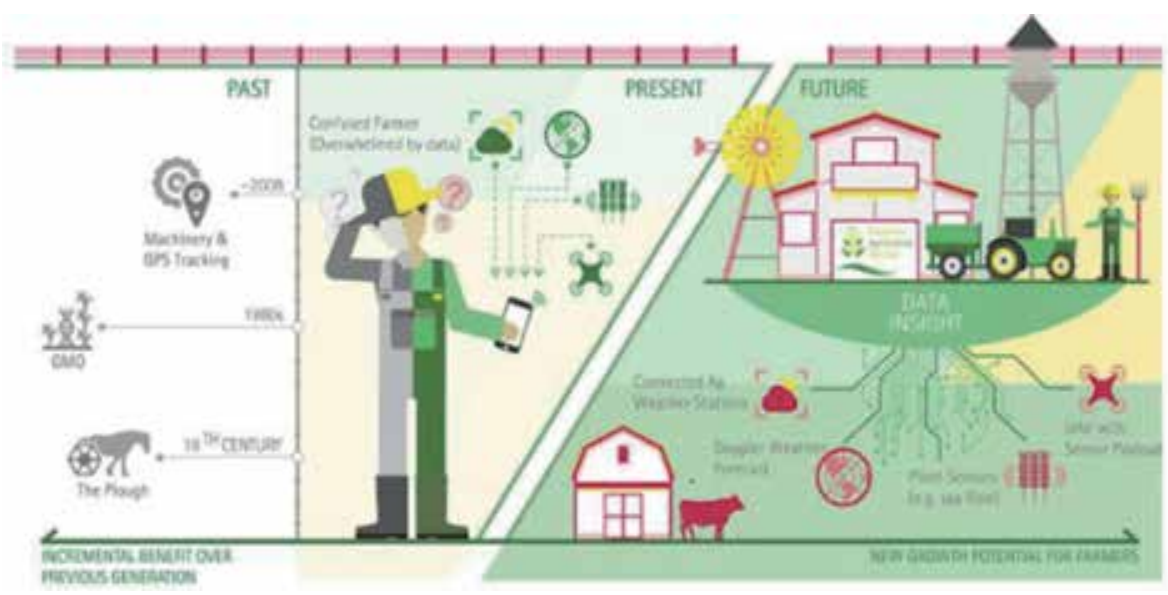

Figure 10.

Evolution of digital agriculture. Source: Accenture.

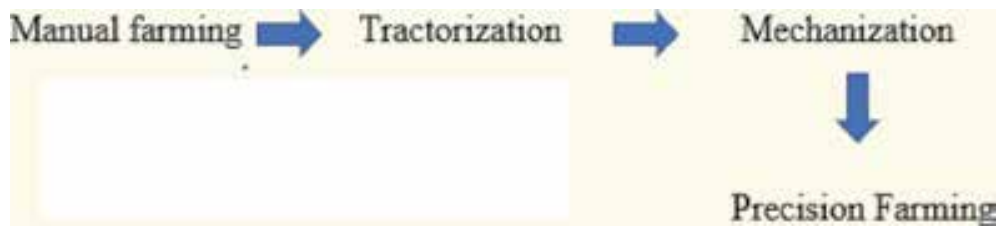

Figure 11.

Transformation in agriculture. Source: Original. 
Many companies are now working to bring realisation of precision farming which would be catalyst in meeting food requirement of future. Current agricultural requirement be it F2C or precision farming necessitates integration of digital marketing in agriculture.

Precision farming is true data driven concept for managing resources and optimising crop production. In last few years, industry has seen agriculture machines are getting equipped with smart intelligent devices to monitor, capture and bring analytical view while working in field. Agricultural machinery giants like New Holland, Case, John Deere, M\&M adopting digital technologies like Sky watch, Eagle Eye, Digi Sense to ensure enabling steps in precision farming. Few digital apps like Mach Rent, CapTon, Farm Passion, DeHaat, Big Basket, Grofers, etc. are connecting farmers with consumer. May start-ups are growing in this field and looking higher opportunity in future.

In a recent survey onto Nebraska farmers, there is adoption scenario of several technologies in agriculture, which shows possibility of resembling future movement of such technology in other countries in recent years. This shows the trend in agriculture integrating digital mechanism into farming practises.

These practises are focussed to increase average crop yield and increasing farm efficiency. One research of Goldman Sachs says there is potential of 1969 US $\$$ bn global crop value by 2050 showing increase of $70 \%$ over current value [10]

(Figures 12 and 13).

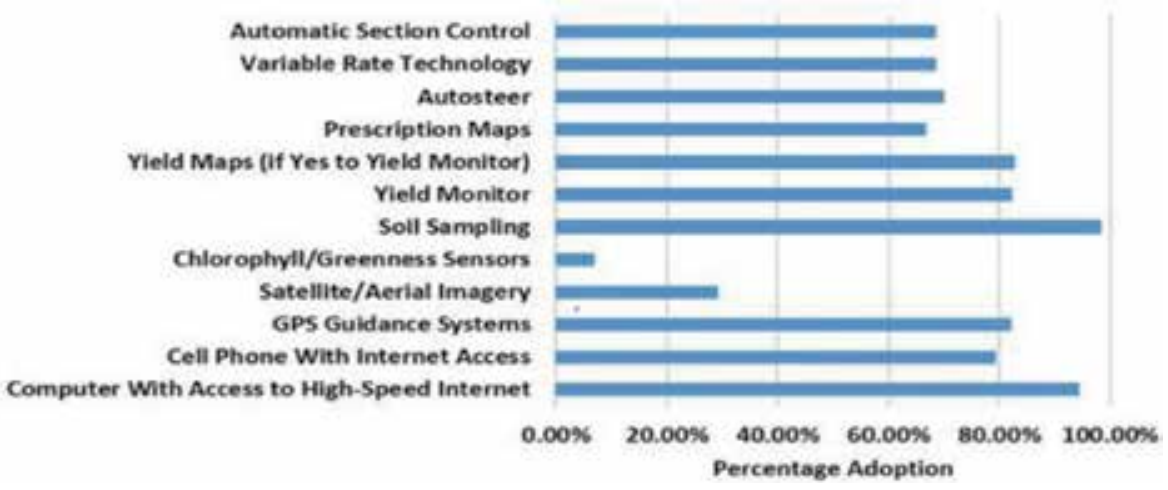

Figure 12.

Precision agriculture technology usage. Source: University of Nebraska-Lincoln.

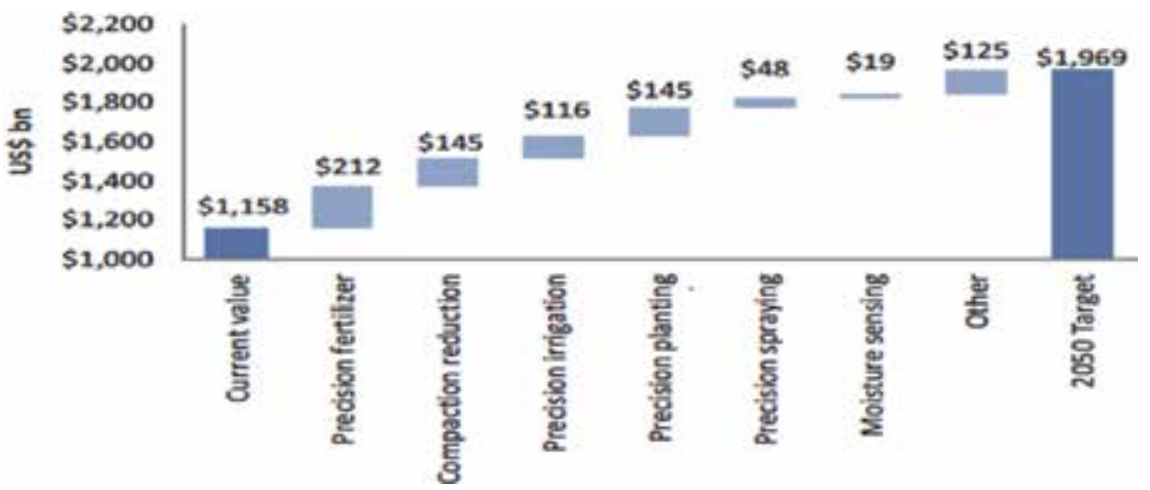

Figure 13.

Tech farm to global crop production. Source: Goldman Sachs Global Investment Research, Company Data. 
The value of digitalisation in precision farming aims to bring better profit and easiness which is targeted to bring educated youth in this segment. This has led a considerable impact on market size of precision farming in developing countries due to current lower cost of farming. Its adoption is significant in bringing improve income, reduce wastage, disseminate information and customer involvement with interaction.

\section{Few of the major digital technologies in agriculture}

One of the recent researches by Goldman Sachs Global Investment says average age of humans has increased in last 30 years and expected world population by 2050 is 9.7 billion, which requires $70 \%$ more growth rate than current to serve the world by 2050 , which is possible with adoption of precision farming that includes digitalisation in agriculture commonly known as digital agriculture [10].

\subsection{Field monitoring}

- Crop health monitoring: With analysis on imagery received with the use of drone and satellite helps to assess the health of crops. It works on the method of Normalised Difference Vegetation Index (NDVI) through the various visible and non-visible wavelengths of light.

- Crop scouting: Using NDVI, scouters capture important crop data on tablet/ mobiles which is then analysed by several platforms to understand the pest and weed activity on farm.

- Yield monitoring and forecasting: Yield sensors/moisture sensors on harvesters, tractors are used to understand best harvesting period. Drone imagery also used to analyse this information.

- Detection of diseases, pests or weeds: Gamaya's hyperspectral camera integrated with software yields input about the extent of pests or weeds in field.

- Weather, irrigation and soil quality: Mechanisms like drip irrigation are popularly used concepts by farmers instead of rain-fed farming. Satellites give proper information about weather and irrigation input. Few plant sensors are used to collect soil quality [10].

\subsection{Data management}

Mobile apps or integrated software linked with farms and farm business network to manage crop production, helping farmers make right decisions on managing farm operations. Presently two types of data management concepts are widely used Europe and USA [10].

- Farm management software platforms: Digital apps providing assistance to farmers with information on and from preparing soil condition suitable to crop to post harvesting, selecting pesticides, insecticides and knowing best sowing times to harvesting time are flourishing currently. Few of apps in India such as FarmLogs, Sirrus, Agrivi, Agworld, AgriDoctor, and Kisan App are widely used. 
- Data platforms: Data platforms are used to predict, guide, assist, prescribe, and produce high-yield crops. It supports to store historical behaviour of farm practise, integrate range of farm data and analyse them to derive and utilise resources suiting best to crop and its yield.

\section{Automation in agro industry}

Technology enabling digitization in farm are now also based on concept with automate the operation with minimal user interface. These needs facilitate development of technologies never seen before like farm robots, guidance system based on GPS, telematics, precision planting [11].

With the onset of these technologies, correct data capturing is ensured in farming which thereby used to determine correct market for the quality of crop produced along with determining right price. Consumers and agri-allied business look digital marketing an opportunity to reach farmers removing middle men. In rural areas, the use of Internet is increasing, and research shows ample opportunity exist in communication, loyalty development, customer service improvement in agriculture sector. Agricultural marketing includes planning, selecting crop, method of land preparation, renting machineries, precision planting, fertilisers, pesticides, choosing right irrigation practices, determining correct harvesting time, grading, packing, transport, storage, selling and promotion. Digital marketing used to connect and promote every step of farming facilitating right use of technology. Like other segment or business, agriculture has all that digital platform can enable it to grow similarly however the intense data mining is the future trend of digitization. Currently digital platform are in mostly used four forms in agriculture [11].

- Website development

- Mobile app development

- Social media marketing

- Content marketing

Education is the base to knowledge and understanding current trend and market. With the penetration of schools and colleges in rural areas, along with high growth of mobile network in rural areas are paving platform to digitization. The challenges of agricultural sector are counter with digital marketing, like selling of crop at right price to right market, digital marketing gives the platform. Daily price of milk, crops, poultry, pulses are get known to farmers through Internet. Training on current agricultural practices is also made possible through Internet. YouTube, Facebook are now widely used among youth in rural areas and become source of networking and connect to world. In long term, digital platform will bring higher consumption in rural India with creating more employment opportunities-this in turn will bring growth in country economy.

\section{Scope of digital marketing}

Few global driving factors to define scope of Digital marketing are briefed below [12]. 
- Digitalisation is directly linked with growth in Internet users. Country like India has seen $63.4 \%$ of all mobile users are accessing Internet from their mobile devices by end of 2019, which is likely to grow $80 \%$ by 2025 globally [13].

- $66 \%$ of users on Internet make buying decisions on digital platform [13].

- E-commerce sales B2B reach $\$ 12$ trillion globally by end of 2019 and likely to grow $\$ 24.3$ trillion by 2025 . India, a developing country, targets to reach US $\$ 200$ billion by 2026 from US $\$ 38$ billion in 2017 (Report based on Meticulous research) with growth rate of $11.1 \%$ CAGR [13].

- Globally 34\% organisations are investing more than half of their annual budget of marketing on digital marketing. Digital contributes alone 51\% in US and $22 \%$ in India against total budget advertisement and marketing promotion share [13].

- Technological development from Radio to Television, Smart Phone to Alexa, development of machine to automated robot scratches $360^{*}$ all around the need of giving comfort with quality, customer satisfaction to delight thereby creating a trend in society for ease of purchase with base of strong reviews and feedback thereby maintaining Trust with loyalty $[12,13]$.

- Trend shows shifting of price conscious market to value conscious and digital market continuously developing to create value of the product and promote the value rather only price and thereby most preferred market place and so growing exponentially.

- Seeing is believing, and based on this concept, digitalisation is also growing.

- Growth in economy, demanding more entrepreneurship and start ups give birth to more brands to come in industry and their need of promotion to larger mass in short period leaves digital marketing as only and best media.

- Technology advancement in artificial intelligence is a new wave in digital marketing.

- In current world, data is money and most valued for every industry and digital marketing is the best platform through which different types of data are preserved, captured, analysed which helps industry to draft his product definition, making belief true-DIGITAL IS FUTURE.

- Creativity backboned with right analysis results correct business decisions which pushes the business with higher ROI. This right analysis is based on data which is possible to capture in digital marketing trend.

- Marketing automation is the trend in society and is expected to grow at a rate of 22\% YOY. This gives digital marketing more exposure to expand and sustain customers [12].

It is seen above factors are working as a catalyst which keeps digital platform booming. Understanding change is the truth of humanity, digital platform keeps on developing new segment and channels of promotion which keeps users stick to the 
digital market place. Every day something new is added to the content platform which maintains the expectation bar excited among users keeping engaged in social and internet platform.

\section{The future of digital marketing}

The future of digital marketing will be integration of successful past technology and growing interest to personalise and customise need of individual.

It has changed most in last 5 years than the shift seen in last 50 years. It has resulted owing to change in human lifestyle and their interest on technology. Every individual business is now tech-savvy and wishes to be more productive and profitable in shortest possible time. Optimization is happening all around, and deliverable made to happen within available resources. Every industry and its segment want to gain and prove his product best in class with superior quality. The real difference in past and future scenario is not the quality of product someone delivering but the service someone offering along with the product will create differentiating factor and put him ahead in business race. Service of delivery and need based customization is the future of all and any product.

The digital transformation trends and strategies are evolving in data cloud, internet-based platform where script post is changing to voice search dominated with artificial intelligence.

There are majorly four factors contributing to the transformation of digital marketing $[8,12]$ :

- Tech advancement

- Storytelling

- Advantage of first mover

- Smart device focussed marketing

Above mentioned factors lead customers gain experiences which keeps him love with the brand and maintain his loyalty.

Tech advancement helps marketers to analyse and form strategies more effectively, making digital marketing more effective and productive. Advancement in technology place you ahead in understanding customer demographics, preferences, behaviour, requirements which helps to decide effective campaign and timing as per for business plan.

- Artificial Intelligence Chatbot: It is a computer program capable of simulating human conversation through oral commands or text chats or both using AI feature that is embedded through smart devices application. It is most seen at Starbucks taking orders for his customers and interacting status of order.

- Data and predictive tools: Data is value and companies are working to capture more data to understand their customer better. In Hotel industry, today they introduced the trend of Alex in rooms to place orders and interact which keeps record of order trends and like dislike of customer which are later analysed by personalised CRM activities of hoteliers to retain and attract more customers. Travel and ecommerce industry are also using predictive tools to 
understand the behaviour and preference of the site visitors before making suitable recommendations which will suit individuals.

- Virtual reality and augmented reality: Augmented reality uses live view like using smartphone camera whereas virtual reality creates an experience out of physical world through complete immersion using independent device like Samsung gear, Microsoft Hololens. Lenskart a known brand for smart glasses allows user to choose best specs suiting your face and style using AR technology making buying experience more customised.

- Marketing automation: It is a platform used to plan and manage marketing campaigns be it online or offline across channels including automated email, messages, websites, and social platform. Automation with predictive tools makes digital campaign super productive.

Story Telling: It is one kind of script in digital media for attracting traffic and connect emotionally, thought provoking and entertaining existing noise to differentiate your business and brands. Content creation in a form of storytelling and video marketing is the new trend to influence traffic. This type of initiative also helps brands to go viral and attain new shapes creating impression on their viewers. Some kind of interacting campaign between the blogger and user keeps attention of traffic making individual brand centric and eye catch new viewer in social media. Recently \#10DaysofGoodwill is one of right example of Siyaram's ads run during Navratri Campaign in India [8].

Advantage of first mover is benefitting in every field and is true for digital marketing campaign. To be placed on top, brand should be capable of implementing latest trends in digital field. As like in recent days, Brands need to create content and be the first mover during technological advancement like shift of image or content post to live streaming videos and capturing traffic on YouTube. Similar trends to be hacked by brands to be on top [8].

Smart device focussed marketing is the change in digital trend where desktop version of website change to mobile device compatibility. Traffic on mobile apps is more than on desktop websites and so websites' compatibility with smart mobile devices is a need of every brand having suitable apps, which function smoothly on the mobile device. Having more of video content than script is most likely to acknowledge by viewer is the prevailing which is now shifting to voice search and command. Compatibility to Voice command is the next move for very website owner or blogger or brand [8, 12].

Fewer future dimensions in digital era described below for understanding [12].

- SEO A/B split testing: It is one of new tool which is used to increase organic traffic without

○ Major change in website

- Sacrificing ranking numbers

It allows isolating variables increasing traffic so as to take targeted approach for changing the content. This tool also protects website being negatively impacted from outside of developer control. Recently with the changes made by Google in their "best practices" with the release of EAT (Expertise, Authoritativeness, Trust) has caused losing more than $50 \%$ traffic in well-known sites of healthcare industry. It gives a targeted approach by defining clear hypothesis statement to work upon for increasing traffic. This testing is carried majorly adopting technique using Clickflow, Google optimise, Google Ads. 
- Programmatic advertising: It is the algorithm buying and selling of advertising space in real time. This process involves software to play a major role and achieved targeted advertising without manual interference or touch. It allows marketer to decide and acknowledge the right segment, demography, tailored script to reach to the right targeted customer at target time. It optimises spend and resource. Programmatic advertising moving at a faster rate into the realms TV, radio, out of home $(\mathrm{OOH})$ advertising (Figure 14) [8].

- Personalization: It consists of tailor made concept in achieving individual or group requirements thereby customising the need and framing the advertising as per the market move and customer base which improves customer satisfaction and leading high rate of digital sale conversion, improving website metrics. It is a key element which is growing with the advancement of technology rendering tastes and varied preference. Deloitte study says, almost $36 \%$ customer preferred to have not only personalised communication but product and services also to be customised and personalised. It is growing in recent years and more advancement is to be seen in this segment (Figure 15).

- Video marketing: It is one of best tools for traffic engagement and keeping audience believing and trusting product with the concept generating through

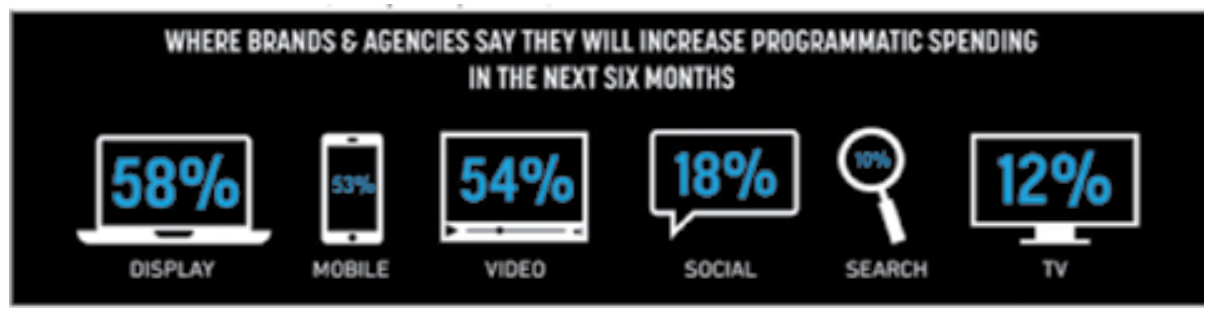

Figure 14 .

Increase in programmatic spending. Source: Forbes (stateofdigital.com-Current State of Programmatic advertising).

\section{6 per cent}
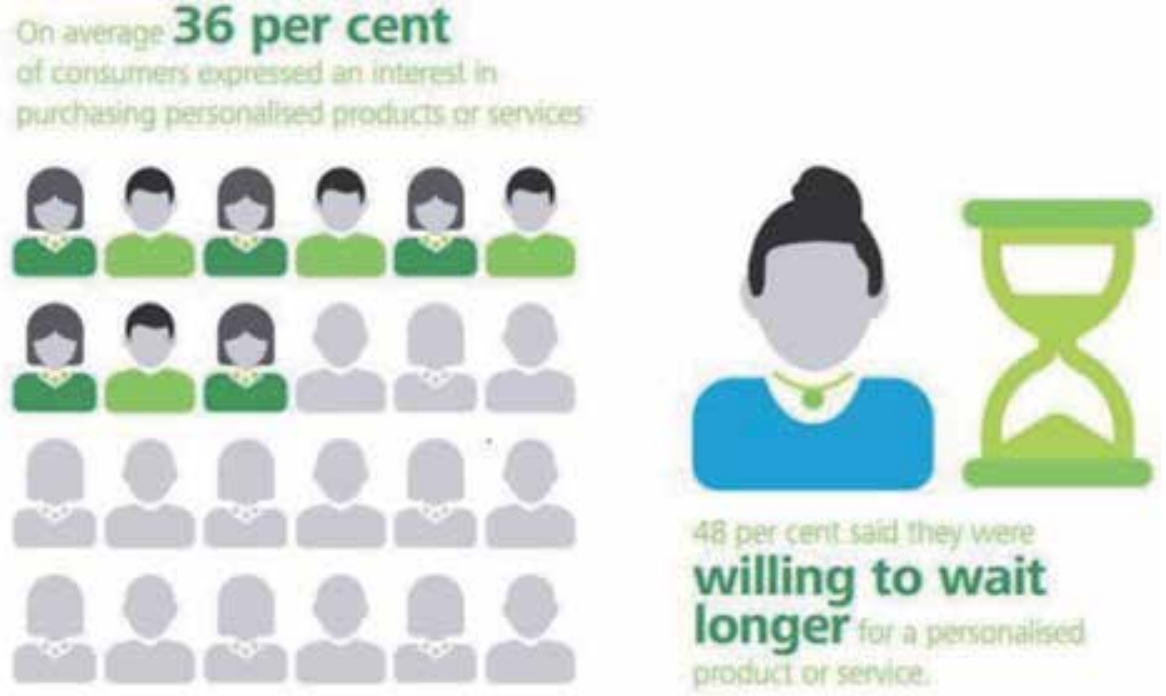

Figure 15.

Representation ratio to personalisation. Source: Digital Marketing Insights. 
video streaming. There are instances of product becoming symbol of message generating through video. Video marketing enables symbolising company's mission and vision in a better way thereby creating more impact than script content and leverage in establishing higher brand value [8].

Few facts on video marketing [8] (Figures 16 and 17)

- Video is more promising in communicating message than the audio or image.

- Facebook video contents are shared more than the image or script post.

- Survey reveals $65 \%$ of information is retained 3 days more by viewers with a visual aid.

- Influencer marketing: Currently one of social website, LinkedIn is seen getting more popular among professional and one of main reason is the endorsement, it brings which creates sense of confidence on content or message been published by individual. This holds true even in marketing where endorsement from known personality, organisations as an influencer becomes active reason for the brand establishment. It works on the credibility factor of individual which symbolises the brand user or recommender. This is one of the safest modes of marketing which also penetrated in digital platform [8].

- Visual search: It is currently trending digitally where someone can search what he sees and can filter search elements based on his preference where instead of text or content he desires to give the image or screenshot of his preference and the search engine give him the result. Recently noticed this development where Google gives the search for any kind of species or flowers which you do not identify whereas once you click the picture and give to search engine, it will result in giving the detail of image. This type of search engine mostly uses techniques related to content based image retrieval. With the development of Google lens camera, it is getting possible where you click

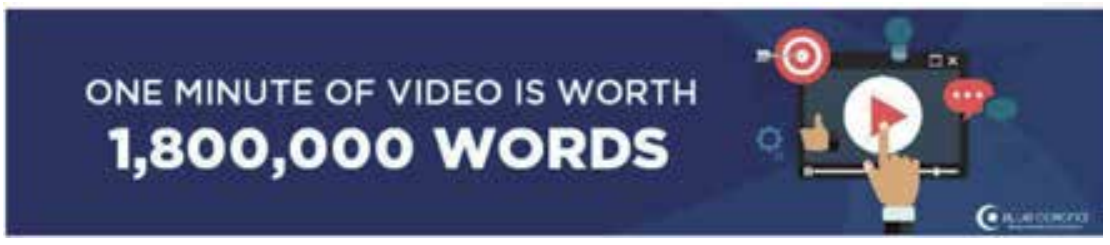

Figure 16.

Video marketing representation. Source: Blue Corona. Measurable Marketing Solutions.

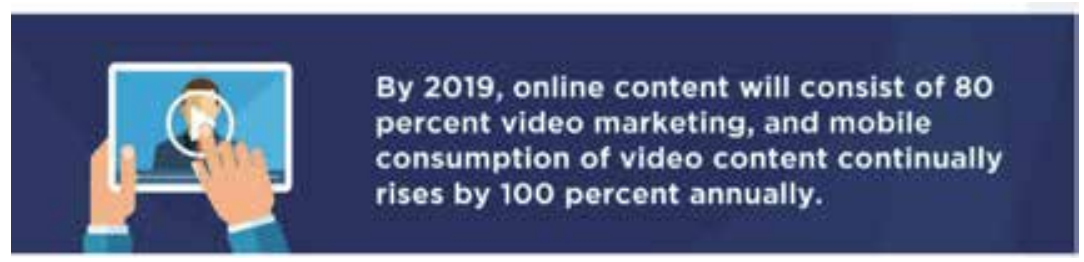

Figure 17.

Video marketing: representation. Source: Bluecorona Available from: https://www.bluecorona.com. 
viewing any brand or object to identify and Google will let you identify through World Wide Web information [14] (Figure 18).

It enables time saving and convenience bringing opportunity for ecommerce where using this feature someone can buy what he likes to see rather which he do not identify which brand or what is the called so but is impulsive buying nature of individual will lead to search through visual search technology. Visual search is now available with Pinterest, Bing, Google [14].

Report by Jumpshot and Moz in 2017 reveals statistics of increasing visual search have rising trend by traffic with $27 \%$ stake in image search for 10 major properties [14].

Micro moments: These moments are I-want-to-know moments where consumers using smart phones or tablets revolve around intent-rich moments. These needs are somewhat related to going, knowing, doing, buying something. These moments are captured using AdSense and thereby providing inputs of brands or results during search. Analysing micro moments helps to decide brand its sales strategy-make easier buying interface, content as per customer preference, process convenient to consumer $[8,12]$.

- Voice search: With more than a billion-search happening currently becoming a new revenue source, marketers are investing much on regional language artificial intelligence enabled technology voice search which make possible to compile and analyse data. With the onset of Google Assistant, Cortana, Alexa and so like technology it is expected to reach $50 \%$ of search through Voice

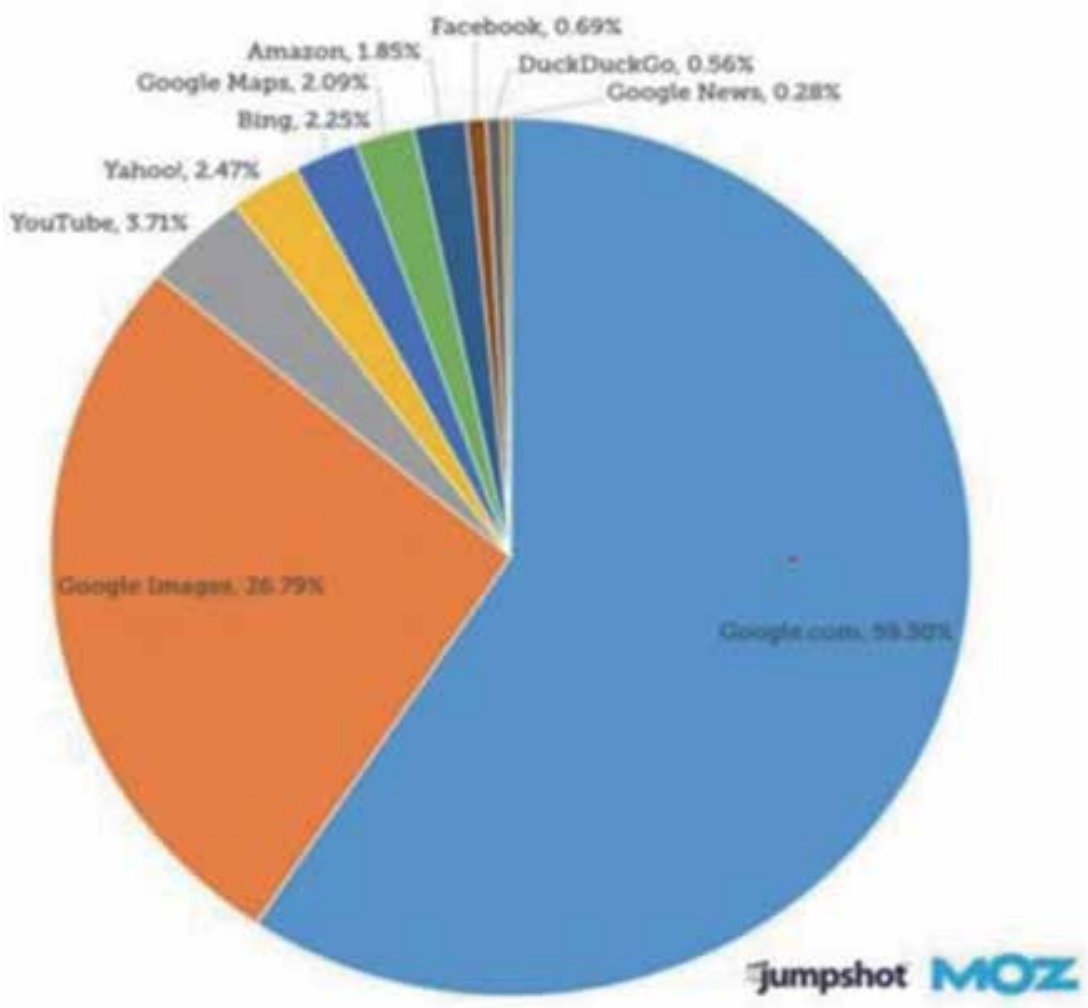

Figure 18.

Distribution of US searches across 10 web properties. Source: Jumpshot's Moz October 2016. 
enabled features by 2020. It is also noted with smart devices in hands, more than $50 \%$ of searches through Voice is seen through mobile or tablet this enables marketers to adopt mobile-first technology approach for marketing or promotion of its product (Figure 19).

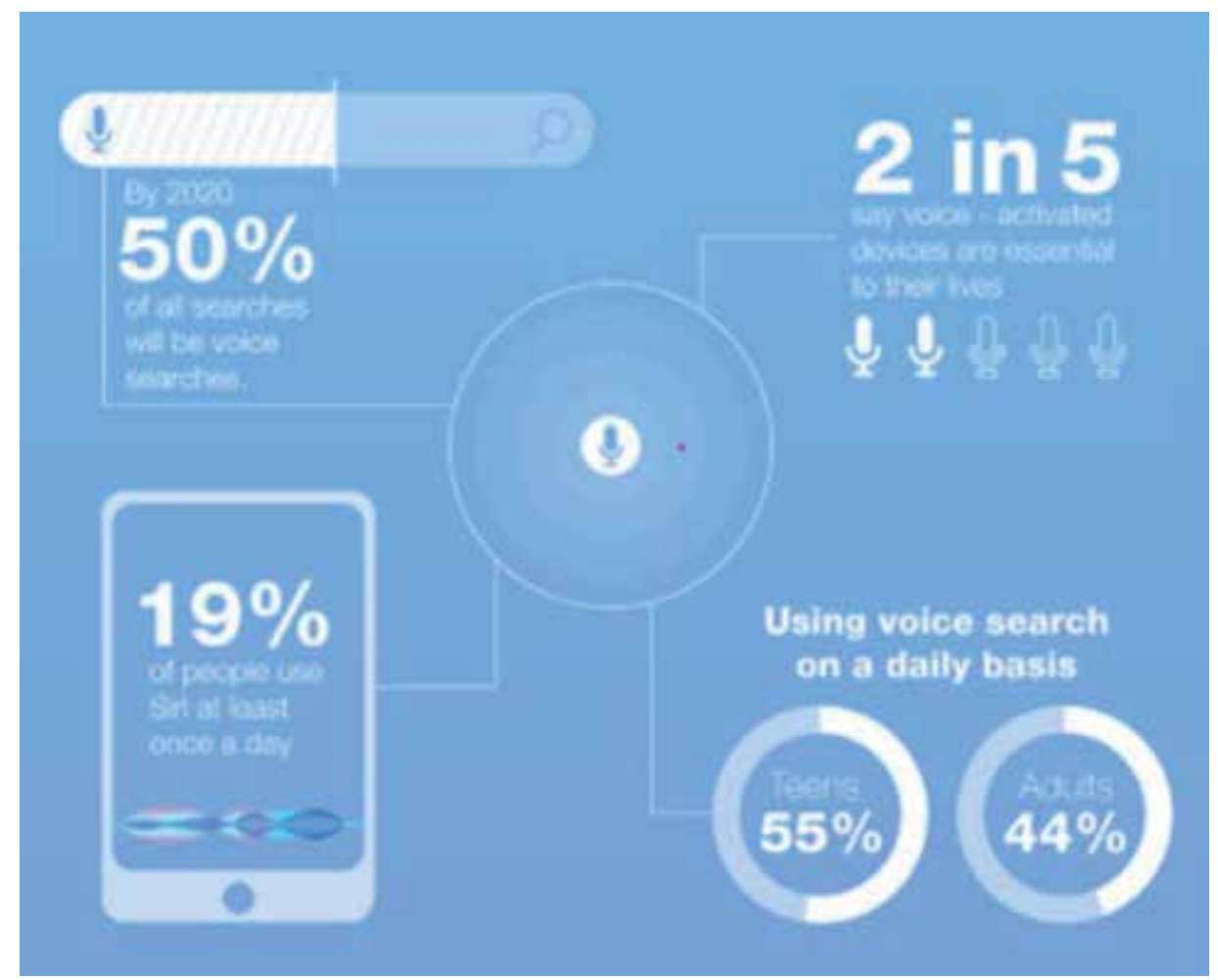

Figure 19.

Voice search: quick stats. Source: Saynetech.

Future $A$ demand trajectory

Average estimated trajectory in Ar igending. noxt a years, weighted by firm slev?

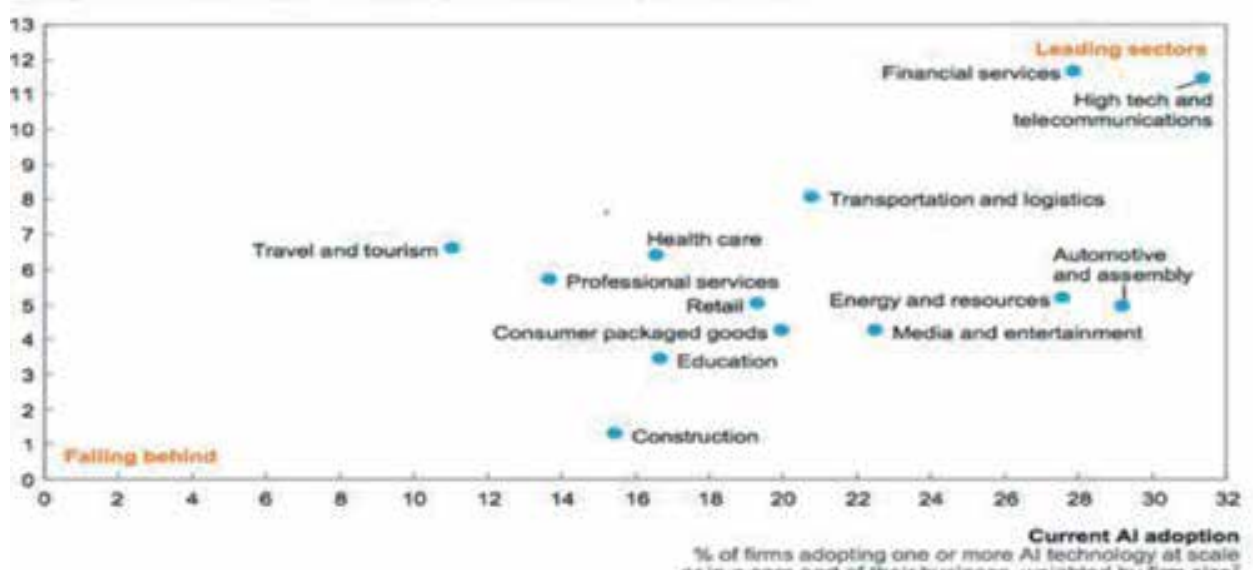

* of firms adopting one or mone Ai technoliogy at scale

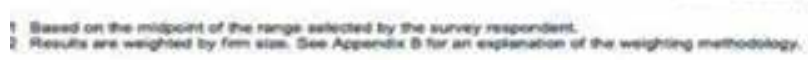

Figure 20.

Future AI demand trajectory. Source: McKinsey Global Institute AI adoption and use survey, McKinsey Global Institute analysis. 
- Artificial intelligence: AI gives intelligence to machine to think, respond, and perform tasks like human. AI in marketing market is said to grow with a CAGR of $26 \%$ reaching 21 bn USD by 2023 [8, 12] (Figure 20).

It is increasing popular because

- It is seamless and work with high efficiency

- More deeper insights are analysed for better experience

- It adapts regular input through progressive learning algorithms

It gives competitive edge to digital marketing owing to its feature [15]

- Understanding need of consumer better

- Enhance user experience and interface

- Increase marketing effectivity

- Increase ROI

\subsection{Latest tools of digital marketing}

Many new companies in recent years with their start up gives boost and new tools to Digital industry. Few of trending tools used by marketer are HubSpot, BuzzSumo, PowToons, Apester, Google Trends which is enabling them to have tools for CRM, content marketing, social media marketing, develop powerful interactive session in terms of power point, data mining, video, supports comparison of search volume, thereby facilitating customer getting attractable, to remain with brand for longer period, sense of delight. These tools are most advanced marketer and breach the gap of consumer need and product development.

\section{Challenges in digital marketing}

It is said World War III between nations will be for data security theft and biggest threat against digitalisation is high chances of data loss, breach of privacy. Data mining is the base of digital marketing and same is the threat owing to its possibility of being hacked by bugs or virus. In current scenario of digital marketing, several data, be it personal or business strategy, plan, or budget, all are available in digital form and have chances of being hacked by someone who can breach subject security. People have become dependent on gadgets and devices, hindering innovation, and new development or discovery is limited, and only improvement in process and product is seen in current scenario. This digital marketing made consumer more powerful by giving several options to choose from big digital platform, raising sense of high competitiveness owing to transparency in price and globalising product (Figure 21).

The challenges evolve every year with the technological advancement in digital platform. Risk of yesterday is gone, and unseen factors of tomorrow are the threat to digital platform. Competition to be as top brand is perceived as biggest challenge in digital world as brands must evolve themselves to understand the evolving need of consumers. This bring brand to reframe and refresh his technology updates 


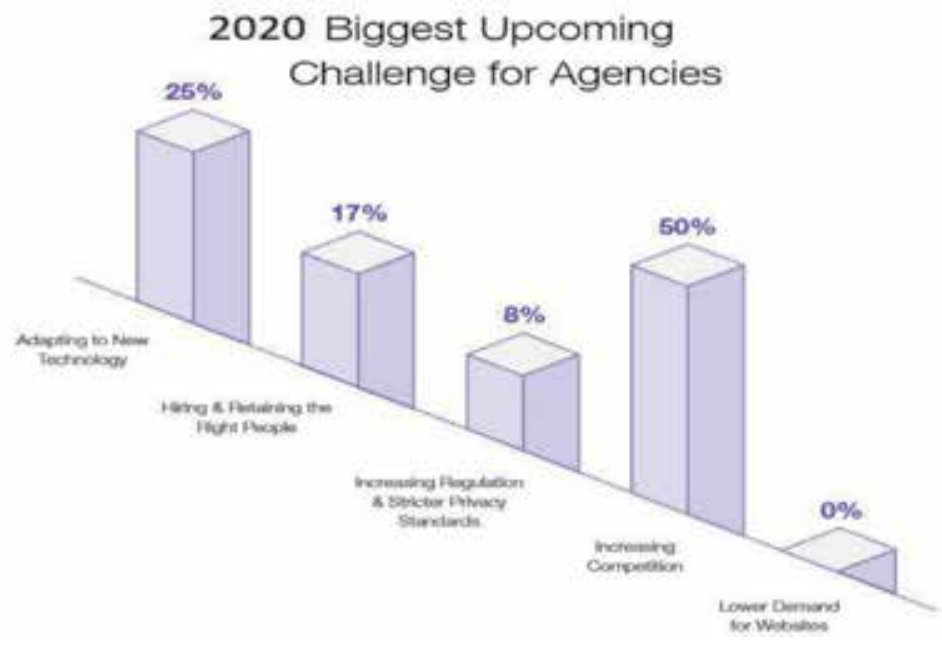

Figure 21.

2020 challenges for agencies. Source: WIX.

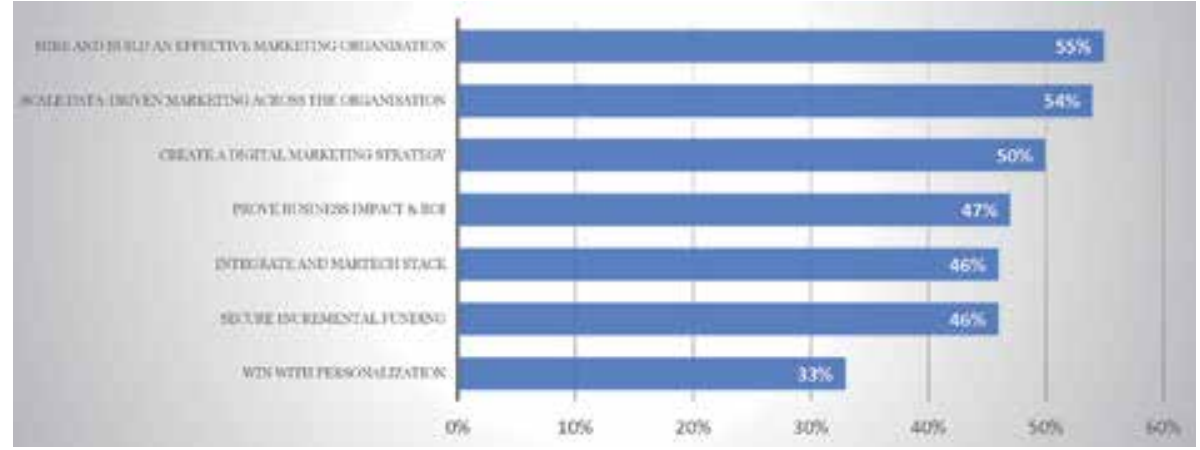

Figure 22.

2019 challenges in digital marketing. Source: State of Inbound Report.

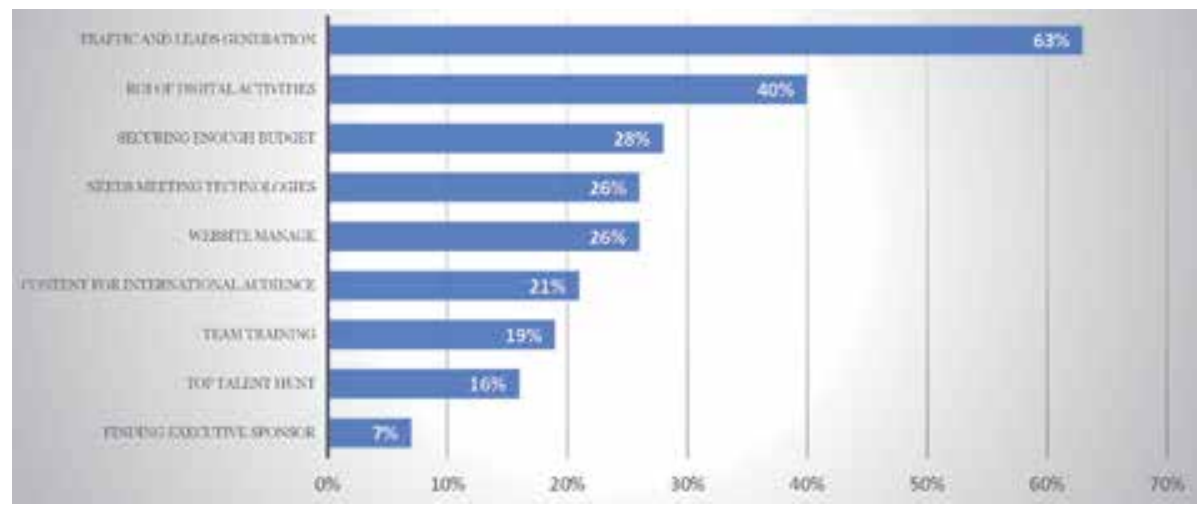

Figure 23.

2017-2018 challenges in digital marketing. Source: State of Inbound Report.

regularly which is challenging to main as every new start up gives a threat to existing technology. Since today product alone is not sold rather service is accompanied with product, the frame of words to product is necessary to build in a way to connect correct features and strength otherwise it even leads to failure of product or 
brand. The fast reach and easily accessible feature of digital platform is even seen sometimes a threat as consumer gives open reviews which is seen by mass and even affects the sales growth of brand.

Discipline and prevailing trend knowledge is needed in handling brand on digital platform (Figures 22 and 23).

\section{Conclusion}

Above article reveals digital market as a new place for different brands where company and consumer can interact and evaluate each other. Significant increase of Internet users seen globally with India crossing 350 million, where $93.91 \%$ make their presence to digital world through mobile devices [16]. Since 2017, JIO as network provider has given India cheapest mode of Internet, leveraging mass usage of Internet in India, giving estimated market for mobile commerce to a tune of $\$ 19$ billion by 2019 [16]. The social media platform has become unique market place for different brands and AI is new language of Digital market which is enabling industry to evolve and increase efficiency. Irrespective of regional differences, digital frequency is unanimously increasing, various age group people accepts online transaction as safe and secure mode, male and female purchase behaviours are same, male female behave somewhat alike with respect to purchase frequency, urbanity and online security perception. Nuclear family is the booster to digital platform, and social networking is available through digital platform. It gives equal opportunity to small and big brand to grow. Internet growing in rural areas, connecting it to urban culture brings immense opportunity to consumer. Technology is acknowledged to have shift in every decade and noticed such shift from Radio to Television to Mobile. Mobile empower consumer with their rights through connect to source of knowledge and as each. Digital marketing helps consumer Connect to product, Create its own requirement. Communicate, Collaborate with brand. Discipline to data privacy by the network and social media platform is sensitive to maintain for enabling extensive and mass usage of digital marketing. Although digital platform has some threats to security and privacy, it is the trend in current society and is accepted worldwide as the biggest market for all brands.

\section{Author details}

Chandan Kumar Mishra

Indian Institute of Management, Kozhikode, Pune, India

*Address all correspondence to: chandan7@alumni.iimk.ac.in

\section{IntechOpen}

(C) 2020 The Author(s). Licensee IntechOpen. This chapter is distributed under the terms of the Creative Commons Attribution License (http://creativecommons.org/licenses/ by/3.0), which permits unrestricted use, distribution, and reproduction in any medium, provided the original work is properly cited. (c) BY 


\section{References}

[1] My Adventures in Marketing: The Autobiography of Philip Kotler. KotlerMarketing.com. 27 June 2017

[2] Kotler PT, Armstrong G, Agnihotri P. Principles of Marketing. 17th ed. 31st March 2018

[3] Ismagilova E, Dwivedi YK, Slade E, Williams MD. Electronic Word of Mouth (eWOM) in the Marketing Context: A State of the Art. January 2017

[4] Global Internet Report + Social Media Statistics \& Facts. 2019. Available from: www.statistica.com

[5] International Telecommunication Union. World Telecommunication/ICT Development Report and Database; 2019

[6] United Nations Fund for Population Activities. The State of the World's Children 2017: Children in a Digital World. August 2018

[7] OECD. Economic Outlook for Southeast Asia, China and India 2018. Development Centre; 2018

[8] Digital Marketing Insights 2018. Social Beat Digital Marketing LLP

[9] Ghosh S. Social Media Success: Strategies to Mastering Your Business or Brand. Educreation Publishing; 2017

[10] G Global Innovation Index 2017: Innovation Feeding the World. Cornell University; INSEAD; World Intellectual Property Organization

[11] Hussmann S. Automation in Agriculture: Securing Food Supplies for Future Generations. March 2018

[12] Hemann C, Burbary K. Digital Marketing Analytics: Making Sense of Consumer Data in a Digital World
[13] Mobile Phone Internet User Oenetration Worldwide 2014-2019. Statista Research Department; 2015

[14] Neher K. Visual Social Marketing For Dummies. Boot Camp Digital; 2013

[15] Shairoz AZ. Make an Impact with Key Digital Marketing Strategies: Ultimate Competitive Marketing Guide for Driving Growth. 2019

[16] Punita D, Anurag S. M-Commerce: Experiencing the Phygital Retail. Apple Academic Press; 2019 
Section 3

Sectoral Developments 



\title{
Dissecting Changes in Consumer Characteristics through Psychographics
}

\author{
Sumitro Sarkum
}

\begin{abstract}
The importance of a psychographic approach is to find out what underlies the lifestyle of people in Indonesia as consumers of various product brands and services circulating in traditional and modern markets. Pattern forming the consumers' insight needs to be known and seen from the activities, desires, and opinions expressed through their shopping styles. Basically, this perception is a way to show others around them that they have different ways of getting what they want. This insight continues to develop along with technological developments that provide convenience in facilitating products and services. This chapter will discuss the consumers' typologies based on their psychographic segment in Indonesia and the influence of technology trends in higher aspiration purchases within online and offline markets.
\end{abstract}

Keywords: psychographics, characteristics of consumer markets, offline and online marketing, new segments of marketing, Labuhanbatu Regency Indonesia

\section{Introduction}

The hustle and bustle of traditional markets and the entry of modern markets in the competition to win the hearts of consumers have changed the face of Labuhanbatu Regency into an area that continues to be in demand by supermarket and mall business practitioners. These forms of modern businesses quickly win the hearts of consumers and expand their market share. Changes and transitions of the modern shops concept also penetrated the local business to be able to compete with the practitioners of mini market businesses that have been scattered almost all over the region. Modern outlets that are displayed offer more to increase the value of consumers' social class that seems luxurious, elegant, fast, and friendly service along with professional management [1]. Those all are different with the appearance presented by business people in traditional outlets, seeming slum, stink, and shabby; therefore, almost most of the traditional business people are eliminated from competition. However, those who quickly adjust to the market-changing conditions can survive even if they seem to live in shame but unwilling to die.

Another factor that arises upon social value in class advancement in Labuhanbatu community is the emergence of online transportation that can spoil consumers by shopping online service with no need to waste time getting out of the house. Modern business people quickly and responsively act to the emergence of 
this online transportation to cooperate in logistics matters. The traditional business people seem slow in responding to this despite starting to join in handling situations and business conditions that are constantly improving. Another case with existing marketplaces in Indonesia such as Tokopedia, Blibli, Bukalapak, Lazada, Zilingo, Shopie, JD.id, and others also influences the shopping style of Labuhanbatu community by consuming permanent goods which are cheaper than the prices in modern and traditional stores.

Changes in the shopping style of Labuhanbatu community are inseparable from the role of internet operators who are increasingly competing with each other to facilitate internet in Indonesia, so that from the corners of the country they can also do the shopping online align with support from many business operators in logistics to spoil consumers.

In this chapter, we will first start by distinguishing geographical groups in Psychographics segmentation in order to know theoretically what they mean and what theories view from the perspective of Psychographics. Then, it proceeds to look at the characteristics of consumers in a developing market and the lifestyle of each consumer. Then, the latest marketing system in Indonesia will be reviewed from both sides: offline and online markets. From this background, it will be possible to judge the possibility of what will happen to the marketing system that has changed by dissecting it through changes in consumers' characteristics toward their lifestyle in shopping.

\section{Psychographics}

Psychographics is not entirely new concept because many researchers have been employing psychographic measurements for many years but simply did not know it. Based on their survey result, Winter and Russell [2] found that Psychographics has a great value to copywriters because it gives them a detailed portrait of the person they are trying to communicate with. Psychographics offers a fresh approach to understand the consumer and is more fully understood by those with the task of communicating with the consumer. Although the need for a common definition of psychographics is obvious, no single definition has met with general approval. However, Wells [3] concluded to the marketing practitioner psychographic methods have offered a way of describing consumers that have many advantages over alternative methods, even though much work on reliability and validity remains to be done. To researchers with more general interests, psychographics methods have offered new ways of looking at old problems, new dimensions for charting trends, and a new vocabulary in which consumer typologies may be described. From the speed with which psychographics have diffused through the marketing community, it seems obvious that they are perceived as meeting a keenly felt need. The problem now is not so much one of pioneering as it is one of sorting out the techniques that work best. As that process proceeds, it seems extremely likely that psychographic methods will gradually become more familiar and less controversial and eventually will merge into the mainstream of marketing research.

While the research which was conducted by Becherer et al. [4] on a questionnaire was mailed to 1000 applicants, 233 of these were respondents who held bank credit card banking services; they found that results of research highlight the potential role of psychographics as a new way to look at an old problem. For this reason, it is necessary to understand that market segmentation is an activity to sort a market into several groups of different buyers with different needs and characteristics and behaviors to meet product needs through different marketing mix. Based on the findings of Burns and Harrison [5], their study on the reliability of 
psychographic measurements during a 1-year time interval does not support the use of this instrument as a precise measure of the lifestyle of the individual consumer. In marketing, the most prevalent method of gaining insight into consumer leisure time activity involvement has been the use of activity and interest items or psychographics [6].

\section{Characteristics of consumer markets in Indonesia}

The characteristics of the consumer market are influenced by several factors including cultural, social, and psychological factors. Cultural factor is the most extensive factor to see consumer behavior, where the basic values of perceptions and desires are based on life experiences so that reality is very permanently influencing behavior. This refers to the influence of social and family status. While personality factors are seen from age, work, life patterns, and self-concepts that shape identity, psychological factors shape someone to be motivated to interpret themselves from their experience and knowledge with their beliefs and attitudes toward one's tendency to remain consistent. In November-December 2004, a survey titled Face of Indonesia [7-9] conducted by Lowe Indonesia and Prompt Research took more than 2000 consumers as sample. They were randomly selected from urban and rural areas throughout Indonesia, with various socioeconomic backgrounds and educational levels. Quantitative research was conducted randomly in 9 of the 63 urban areas in Indonesia, namely Central Jakarta, Bandung, Makassar, Gianyar, Magelang, Padang, Lampung, Surabaya, and Sidoarjo. Representing 78 rural areas, 8 regions were randomly selected, namely Bekasi, Garut, Karanganyar, Magetan, Lumajang, Tegal, Prabumulih, and Padang Sidempuan [10]. This survey dissects the following eight consumer characters in Indonesia:

1. Consumer behavior and attitude in seeing the brand

2. The type of brand wanted

3. Consumer aspirations in choosing products

4. Activities that represent themselves in various conditions

5. The effect of advertising on purchasing behavior

6. The most aspirational media as a window to life

7. Types of advertisements wanted

The following are eight psychographic segments that describe consumers in Indonesia:

\section{Established confident}

The demographic percentage is $15.2 \%$, generally men of mature age, highly educated, and living in urban areas. Very confident and strong character likes peace in his social life, very normative, and helpful. The picture that approached him might be the figure of a good father; in this group, the basic desire is to put the family more than the material, have a good reputation, and is to be quite acceptable to the community. 


\section{The optimistic domestic goddess}

The number of the optimistic domestic goddess is quite large, $13.5 \%$. The character of the group, mostly mature women from rural areas with low socioeconomic conditions, is trying to live a modest, realistic, family, and normative life. Like housewives in Indonesia, they like cooking as a hobby, not just an obligation. Their basic desires are neither material nor any other things since family is everything.

\section{The chance-expecting lad}

This group is a group of consumers of which $10.5 \%$ are boys, living in urban areas, but their socioeconomic level is lower middle class. Their character is life oriented toward friends (group). The word "friends" for them means "One for all, all for one." According to them, friends are everything. For the sake of friends, they will do anything. Because of the circumstances and the environment, they are very tolerant of sex. To be accepted and loved by friends has become their basic desire. Friends have been their life motivation and material for them or are still a means of survival. This group is usually seen hanging out in malls (neither in restaurants nor cafes) while joking and smoking.

\section{The cheerful humanist}

This group has $12.1 \%$ in number. This group, which mostly consists of young women from rural areas with low socioeconomic levels, tends not to be the center of attention, even though it is accepted in their environment. They like a peaceful environment full of harmony. They are very attentive and empathetic to the environment and the people around them and feel very valued if the environment accepts them as they are. With such a character, their basic desires are clearly not concerned with the material but want to always be needed by the environment and enjoy being together.

\section{The introverted wallflower}

Identified about $8.1 \%$ of the entire population of Indonesia, they are generally mature-age women who have low education and live in the area. Because their lives are mediocre, this consumer group does not have many desires and is not too optimistic about their future. They tend to flow like water, without having to "disturb" other people.

\section{The savvy conqueror/city slickers}

This group is very straightforward and attractive. His goal in life is to achieve glory. Therefore, they really like to compete and tend to be dominant in relationships. Those who are generally mature educated men, from urban areas, would really enjoy their life. As an example is their attitude toward sex as a form of relaxation. They really like fashion, enjoy cuisine, and fond of advertising. Thus, their basic desire that always arises is to be pampered with material and possessions, to be flattered and revered, as well as accommodating and full of energy. These attractive consumers are demographically very large in number, about $16 \%$.

\section{The networking pleasure seeker}

It is also quite large in amount, around $11 \%$ of total Indonesian consumers. They are such consumers who are very open, sociable, and full of passion. They generally are also dominated by women of mature age, but they live in urban areas with an A + socio-economic level. They are very materialistic, and for them, possessing 
(wealth/things) is the peak of happiness in life. Moreover, they feel that the success achieved was not obtained from formal education.

Believe that friendship is an investment, in their eyes; friendship is more like networking than bonding. So for them, self-recognition exists if it is highly accepted by the social environment. According to them, friends (relatives/families) are supporters of their success.

\section{Spontaneous fun-loving}

This group stands around $13.6 \%$. Similar to the men (The Savvy Conqueror), a group of mostly women from urban areas with high socioeconomic really likes to be the center of attention. They like to get along, show off, and involve in activities outside home, such as parties and gatherings. They like new things that are becoming trends, like fashion and gadgets, and really enjoy life. They believe that material is a tool to meet the demands of lifestyle, flattery and idol are a proof of self-recognition, and the group is a means of achieving popularity.

In general, it has been identified that the following are typically the Indonesian consumer's behaviors:

a. Really care about the people around

b. Very concerned about people's opinions about him

c. Feel uncomfortable if alienated from the environment

d. Care deeply about norms and traditions

e. Uphold seniority compared with one's abilities

f. Looking for a safe position in the social strata

g. Crave harmony and polite relations

h. Prioritize cooperation rather than working alone

i. Expect people to do the same thing as he did

This typical Indonesian consumer is not directly related to the way of consumption, but from the beginning Lowe Indonesia agreed that there is a narrative of consumption, where the consumption has a story and basically the consumer is an actor. Consumer attitudes toward advertising, direct marketing, and promotion show that $80.47 \%$ of the preferred advertisements are funny and entertaining. While the level of consumer optimism, $78.01 \%$ believes that the ability to provide better material for the family than experience can lead to success in the future up to $72.57 \%$. Consumer opinion on traditional Indonesian values shows $70.66 \%$ that the views of Indonesian people have changed a lot. Likewise with the view of sexual permissiveness, Indonesian consumers do not care about the sex lives of others as long as it can be addressed in an adult manner.

Proving the results of the survey, this chapter explains the results of the survey reconducted to dissect the characteristics of consumers in other regions in Indonesia, namely Labuhanbatu district. Samples taken randomly were conducted on a minimum sample of 312 people [11], by not changing the indicators in the eight 
Psychographic clusters of Indonesian consumer behavior. Changes in survey findings can be seen in Table 1.

In Table 1, it shows that consumer behavior is still assessing the same brand whether it is from overseas and local with quality, but there is nothing new in the

\begin{tabular}{|c|c|c|c|}
\hline Indicators & Characteristics & Survey 2019 & Survey 2004 [9] \\
\hline \multirow[t]{8}{*}{ Brand insight } & $\begin{array}{l}\text { Established } \\
\text { confidents }\end{array}$ & $\begin{array}{l}\text { High-quality brands both local } \\
\text { and abroad, halal logo is } \\
\text { included, not too expensive, } \\
\text { easy to find, can be maintained, } \\
\text { and able to understand } \\
\text { consumer needs and durable }\end{array}$ & $\begin{array}{l}\text { Brand easily established, } \\
\text { conservative style, expensive } \\
\text { prices, made of durable } \\
\text { materials, sold at special outlets, } \\
\text { local and abroad }\end{array}$ \\
\hline & $\begin{array}{l}\text { The optimistic } \\
\text { family person }\end{array}$ & $\begin{array}{l}\text { Not brand-focused, easy to } \\
\text { reach and has a low price }\end{array}$ & $\begin{array}{l}\text { Not well known to the famous } \\
\text { brands(certain), widely used by } \\
\text { people, trendy, the prices can be } \\
\text { cheap or expensive }\end{array}$ \\
\hline & $\begin{array}{l}\text { The change- } \\
\text { expecting lad }\end{array}$ & $\begin{array}{l}\text { A brand that can make the } \\
\text { consumers feel proud when } \\
\text { using it, seems glamorous, } \\
\text { luxurious, and affordable }\end{array}$ & $\begin{array}{l}\text { Fast food/drink, cheap prices, } \\
\text { popular, simple, made in Japan } \\
\text { or China }\end{array}$ \\
\hline & $\begin{array}{l}\text { Cheerful } \\
\text { humanist }\end{array}$ & $\begin{array}{l}\text { Brands that are able to meet the } \\
\text { needs, varied, widely used in } \\
\text { accordance with the criteria and } \\
\text { affordable prices }\end{array}$ & $\begin{array}{l}\text { Unknown to famous brands } \\
\text { (certain), brands are widely } \\
\text { used by people, trendy, low } \\
\text { prices }\end{array}$ \\
\hline & $\begin{array}{l}\text { Introvert } \\
\text { wallflower }\end{array}$ & $\begin{array}{l}\text { Low prices, easy to get, } \\
\text { available anywhere, affordable, } \\
\text { hygienic, tasty, attractive, and } \\
\text { up-to-date product brands }\end{array}$ & $\begin{array}{l}\text { Food and beverage products } \\
\text { that will be processed again, } \\
\text { toiletries are cheap, cheap } \\
\text { electronics, festive, investment } \\
\text { with a small budget }\end{array}$ \\
\hline & $\begin{array}{l}\text { The savvy } \\
\text { conqueror/city } \\
\text { slickers }\end{array}$ & $\begin{array}{l}\text { Popular and expensive products } \\
\text { that make consumers look } \\
\text { glamorous when using them, } \\
\text { well-known and high-quality } \\
\text { products }\end{array}$ & $\begin{array}{l}\text { - Premium food and drinks } \\
\text { of various kinds, available } \\
\text { in luxury places, clothing } \\
\text { and cosmetics, brands } \\
\text { made in foreign countries } \\
\text { - Multi-functional, newest, } \\
\text { compatible, imported, } \\
\text { futuristic body design, } \\
\text { high technology } \\
\text { applicable models } \\
\text { - Vehicles designed for } \\
\text { high speed, branded, } \\
\text { comfortable, futuristic, } \\
\text { made in Europe, America, } \\
\text { Japan, Korea }\end{array}$ \\
\hline & $\begin{array}{l}\text { The networking } \\
\text { pleasure seeker }\end{array}$ & $\begin{array}{l}\text { Brands that can understand my } \\
\text { needs are produced by well- } \\
\text { known companies with quality } \\
\text { products, expensive prices, } \\
\text { standardized, trendy, imported } \\
\text { quality }\end{array}$ & $\begin{array}{l}\text { Famous brands, produced by } \\
\text { well-known companies, have } \\
\text { cheap-expensive prices, quality, } \\
\text { trendy, the latest models/series, } \\
\text { futuristic, and foreign-made }\end{array}$ \\
\hline & $\begin{array}{l}\text { The } \\
\text { spontaneous } \\
\text { fun-loving }\end{array}$ & $\begin{array}{l}\text { Famous brands, trendy, stylish, } \\
\text { guaranteed quality, affordable, } \\
\text { and luxurious }\end{array}$ & $\begin{array}{l}\text { Famous brands, trendy, stylish, } \\
\text { bought at premium, models, } \\
\text { online banking systems, } \\
\text { available in shopping centers, } \\
\text { and accepted at many newest, } \\
\text { futuristic, handmade merchants } \\
\text { overseas }\end{array}$ \\
\hline
\end{tabular}


Dissecting Changes in Consumer Characteristics through Psychographics

DOI: http://dx.doi.org/10.5772/intechopen.89635

\begin{tabular}{llll}
\hline Indicators & Characteristics & Survey 2019 & Survey 2004 [9] \\
\hline Some relevant & Established & Almira, holster wadimor, Gajah & Tissot, Tagheur, Guess, Seiko, \\
brands & duduk, Atlas, zoya, Rabbani, & Nokia 9210, 9300, 9500, \\
& Lucky Strike, Djie Sam Soe, & Motorolla, Bally, Hush N \\
& Sampoerna, Dunhill, Marlboro, & Puppies, Next, Everbest, Toyota \\
& Surya, Oppo, Vivo, Toyota, & (Toyota) Innova \\
& Suzuki, Honda, Yamaha, & \\
& Honda, Suzuki, Nokia, Xiomi, \\
& Polytron, LG, Polytron, \\
& Panasonic, Samsung, Iphone, \\
& Puma, Loggo, Gucci, Converse, \\
& Brick, Fladeo, Yongki Kamladi, \\
& Krisbow, Alexander Cristie, & \\
& Masako, Cosmos, Tupperware, \\
& Seiko, Mustika queen, Lifeboy, \\
& Biore, Downy, Daia
\end{tabular}

The optimistic family person
Cooking spices such as royco, dolphin salt, blue triangle. Cosmetic tools (wardah, ponds, viva, pixy inez, mustika queen, olay), nuvo, Daia, lux, hock, rinai, kirin, maspion, sharp, Nokia

\begin{tabular}{|c|c|c|}
\hline $\begin{array}{l}\text { The change- } \\
\text { expecting lad }\end{array}$ & $\begin{array}{l}\text { Shoes (Adidas, Nike, Ardiles, } \\
\text { Vans, Bata, Carvil) clothing } \\
\text { (Hugo, Room, Bontera, } \\
\text { Cardinal, Cresida), Vivo, Oppo, } \\
\text { Samsung, Yamaha, Honda, } \\
\text { Honda, Suzuki, Garnier, Biore, } \\
\text { Pond’s, Pop Mie, Indomie, KFC, } \\
\text { Le Mineral, Walls, Amanda } \\
\text { Brownis, Yakult, Sprite, } \\
\text { Marlboro, Sampoerna, Surya }\end{array}$ & $\begin{array}{l}\text { Indomie, Indomilk Milk, KFC, } \\
\text { Kapal Api, Coca Cola, } \\
\text { Alexander Christy, Casio G- } \\
\text { Shock, Yamaha, Honda, Jin } \\
\text { Ceng, Polytron, Digitek, } \\
\text { Sampoerna A Mild, Gatsby, } \\
\text { Tanco }\end{array}$ \\
\hline $\begin{array}{l}\text { Cheerful } \\
\text { humanist }\end{array}$ & $\begin{array}{l}\text { Skincare: Citra, Wardah, } \\
\text { Harmony Soap, Downy, and } \\
\text { Molto Clothing fragrance, } \\
\text { Oppo, Samsung, Indomie, Pop } \\
\text { Mie, Wardah, Mustika Ratu, } \\
\text { Wadimor cover, Exona, } \\
\text { Konicare, My baby, Johnson and } \\
\text { Tupperware }\end{array}$ & $\begin{array}{l}\text { Instant noodles Supermi, } \\
\text { Indomie, Salami, mie Sedaap, } \\
\text { Pop Ice powder drinks, Viva, } \\
\text { Marina, Sari Ayu, Mustika Ratu, } \\
\text { Ponds, Adidas, Fila, Nokia } \\
\text { 2100, 2600, 3300, Sony Ericson } \\
\text { T230, J200 }\end{array}$ \\
\hline $\begin{array}{l}\text { Introvert } \\
\text { wallflower }\end{array}$ & $\begin{array}{l}\text { Harmony Soap, Royco, } \\
\text { Ajinomoto, Masako, Baygon, } \\
\text { My Baby, Ponds, Olay, Detol, } \\
\text { Molto, Instant Noodles, SOS } \\
\text { Bottle Tea, Flag, Clear, Sunsilk, } \\
\text { Lifebuoy, Lux, Milo, Harmony, } \\
\text { Daia, Molto Mas, Economic } \\
\text { soap, bukrim, Oppo, Nakio, } \\
\text { Changhong, Panasonic and } \\
\text { Blackberry }\end{array}$ & $\begin{array}{l}\text { Masako, Miwon, Ajonomoto, } \\
\text { The Sariwangi, Bimoli, Kunci } \\
\text { Mas, Kopi Kapal Api, Wheat } \\
\text { Flour from Bogasari, GIV, } \\
\text { Lifebuoy, Lux, Fujitec, Akira, } \\
\text { Crystal, BRI and BNI savings }\end{array}$ \\
\hline $\begin{array}{l}\text { The savvy } \\
\text { conqueror/city } \\
\text { slickers }\end{array}$ & $\begin{array}{l}\text { Nike, Adidas, Reebok, Canon, } \\
\text { Toyota, Philip brand shoes, J.CO } \\
\text { Donuts }\end{array}$ & $\begin{array}{l}\text { - Starbucks Coffee, Tamani } \\
\text { Cafe Steak, Win Café, } \\
\text { Piza Café ice cream, flush } \\
\text { bred talk bread, mineral } \\
\text { water Equil, coca cola } \\
\text { diet, beer, country juice } \\
\text { choice, berry juice, }\end{array}$ \\
\hline
\end{tabular}

Dry noodles, Dua telor, Bogasari: segitiga biru-kunci, cakra, Filma, Royco, Kecap Bango, Sari Ayu, Mustika Ratu, Ponds, Nivea, Oriflame, Accent, Executive 99, Alba, Citizen, Bata, Eagle

(n)

. 


\begin{tabular}{|c|c|c|c|}
\hline Indicators & Characteristics & Survey 2019 & Survey 2004 [9] \\
\hline & & & $\begin{array}{l}\text { fisherman friends, } \\
\text { fox, etc. } \\
\text { Panasonic, Philip, } \\
\text { Electrolux, Sony, } \\
\text { Samsung, Pioneer, } \\
\text { Kenwood, Hewlett } \\
\text { Package, IBM, Toshiba, } \\
\text { Vertus, Nokia, Samsung, } \\
\text { Motorolla, O2, Tag } \\
\text { Heuer, Swatch } \\
\text { Mercedes Benz, BMW, } \\
\text { Audi, Wrangler, Ford, } \\
\text { Lexus, VW, Maserati, } \\
\text { Ducati, Harley Davidson, } \\
\text { Cagiva, Tony Car, } \\
\text { Honda, etc. } \\
\text { Valino, Van Heusen, G } \\
\text { 2000, Arrow, Nike, } \\
\text { Adidas, Reebok, Fila, } \\
\text { Next, And1, M 2000, } \\
\text { Levis, Dunhill, Doviduff, } \\
\text { Giorgio Armani, Hugo, } \\
\text { Boss, CK1 }\end{array}$ \\
\hline & $\begin{array}{l}\text { The networking } \\
\text { pleasure seeker }\end{array}$ & $\begin{array}{l}\text { Inez, wardah, mustika queen, } \\
\text { oriflame, yongki komaladi, } \\
\text { rabbani, zoya, brick, elzatta, } \\
\text { azale, honda }\end{array}$ & $\begin{array}{l}\text { Sari Ayu, Mustika queen, } \\
\text { Pantene, Lifebuoy, Alba, } \\
\text { Citizen, Rado, Tissot, Toyota } \\
\text { (Innova, Vios, Avanza, etc.)), as } \\
\text { well as well-known local brands, } \\
\text { Nokia } 7260,9300,9500 \text {, Sony } \\
\text { Ericson K7000, S700 }\end{array}$ \\
\hline & $\begin{array}{l}\text { The } \\
\text { spontaneous } \\
\text { fun-loving }\end{array}$ & $\begin{array}{l}\text { Coffee Crowd, KFC, the body } \\
\text { shop, Oriflame, Wardah, } \\
\text { Converse All Star, Nike, Honda, } \\
\text { Rabbani, Charles and Keith }\end{array}$ & $\begin{array}{l}\text { Starbuck Coffee, Tamani Café, } \\
\text { The Body Shop, Revlon, } \\
\text { Kanebo, Mark \& Spencer, } \\
\text { G2000, Kijang Innova, Toyota } \\
\text { Vios, Honda Odessy, Nokia } \\
\text { 7650, Citibank, HSBC, BCA, } \\
\text { Amex }\end{array}$ \\
\hline \multirow[t]{3}{*}{$\begin{array}{l}\text { Strategy to } \\
\text { work on the } \\
\text { market }\end{array}$} & $\begin{array}{l}\text { Established } \\
\text { confidents }\end{array}$ & $\begin{array}{l}\text { Easily found in markets, mini- } \\
\text { markets, supermarkets, clean } \\
\text { and safe, advertisements in } \\
\text { various media and often hold } \\
\text { discounts. The product is placed } \\
\text { in a strategic position and has a } \\
\text { discount or give away for each } \\
\text { purchase of the product. } \\
\text { Improve quality and reduce } \\
\text { selling prices }\end{array}$ & $\begin{array}{l}\text { Niche market strategy, product } \\
\text { differentiation strategy, } \\
\text { premium price strategy, placing } \\
\text { products in executive outlets at } \\
\text { premium prices (places made } \\
\text { exclusively) }\end{array}$ \\
\hline & $\begin{array}{l}\text { The optimistic } \\
\text { family person }\end{array}$ & $\begin{array}{l}\text { The company maintains the } \\
\text { product quality, easy to reach, } \\
\text { has many discounts, and can be } \\
\text { paid with credit }\end{array}$ & $\begin{array}{l}\text { Mass market strategy, } \\
\text { specifically for FMCG, products } \\
\text { must be available even in the } \\
\text { level of stalls and available in } \\
\text { traditional markets, promotions } \\
\text { especially above the line (ATL) } \\
\text { (television) }\end{array}$ \\
\hline & $\begin{array}{l}\text { The change- } \\
\text { expecting lad }\end{array}$ & $\begin{array}{l}\text { The company releases products } \\
\text { that follow trends, easy to reach, } \\
\text { mass strategy, affordable prices }\end{array}$ & $\begin{array}{l}\text { Mass marketing strategy, mass } \\
\text { product strategy, placing } \\
\text { products in traditional outlets } \\
\text { with visitors from low SES }\end{array}$ \\
\hline
\end{tabular}




\begin{tabular}{|c|c|c|c|}
\hline \multirow[t]{7}{*}{ Indicators } & Characteristics & Survey 2019 & Survey 2004 [9] \\
\hline & & & $\begin{array}{l}\text { levels offering low-priced } \\
\text { products }\end{array}$ \\
\hline & $\begin{array}{l}\text { Cheerful } \\
\text { humanist }\end{array}$ & $\begin{array}{l}\text { The company lists the } \\
\text { composition of the product, has } \\
\text { a BPOM permit, made of } \\
\text { materials that are safe for the } \\
\text { skin, and halal label, easily } \\
\text { obtained and sold at the market } \\
\text { center, stores and mini markets }\end{array}$ & $\begin{array}{l}\text { Mass market strategy, lower } \\
\text { price strategy, specifically for } \\
\text { FMCG: products must be } \\
\text { available to the level of stalls } \\
\text { and available in traditional } \\
\text { markets, promotion especially } \\
\text { ATL (television) }\end{array}$ \\
\hline & $\begin{array}{l}\text { Introvert } \\
\text { wallflower }\end{array}$ & $\begin{array}{l}\text { Companies must be able to } \\
\text { make consumers interested in } \\
\text { good and quality products by } \\
\text { doing extensive marketing on a } \\
\text { large scale, affordable prices, } \\
\text { easy to get, and have sale } \\
\text { promotional programs }\end{array}$ & $\begin{array}{l}\text { Mass marketing that emphasize } \\
\text { product functions }\end{array}$ \\
\hline & $\begin{array}{l}\text { The savvy } \\
\text { conqueror/city } \\
\text { slickers }\end{array}$ & $\begin{array}{l}\text { The company should focus its } \\
\text { products on just one type of } \\
\text { product that is different from } \\
\text { similar products and has a } \\
\text { warranty, for example, } \\
\text { smartphone products, } \\
\text { television, cars, etc. }\end{array}$ & $\begin{array}{l}\text { Niche-market strategy, product } \\
\text { differentiation, premium prices, } \\
\text { outlets in prestigious locations, } \\
\text { intended for the SES A \& B }\end{array}$ \\
\hline & $\begin{array}{l}\text { The networking } \\
\text { pleasure seeker }\end{array}$ & Available at the mall, up to date & $\begin{array}{l}\text { Mass market strategy, product } \\
\text { differentiation strategy, value } \\
\text { oriented }\end{array}$ \\
\hline & $\begin{array}{l}\text { The } \\
\text { spontaneous } \\
\text { fun-loving }\end{array}$ & $\begin{array}{l}\text { Placing products in good, } \\
\text { luxurious, and comfortable } \\
\text { outlets, premium prices, } \\
\text { appropriate quality, providing a } \\
\text { place to negotiate }\end{array}$ & $\begin{array}{l}\text { Niche market strategy, product } \\
\text { differentiation strategy, } \\
\text { premium price strategy, placing } \\
\text { products in exclusive outlets/ } \\
\text { outlets }\end{array}$ \\
\hline \multirow[t]{6}{*}{ Packaging } & $\begin{array}{l}\text { Established } \\
\text { confidents }\end{array}$ & $\begin{array}{l}\text { Simple and easy to carry } \\
\text { product packaging. Tidy, } \\
\text { comfortable, durable, not easily } \\
\text { damaged, and looks elegant, } \\
\text { beautiful with attractive colors, } \\
\text { sealed, halal labeled, safe, and } \\
\text { waterproof }\end{array}$ & $\begin{array}{l}\text { Conservative colors, } \\
\text { unobtrusive, displaying brands } \\
\text { and logos, elegant, perceived } \\
\text { quality, including natural raw } \\
\text { materials, not easily damaged, } \\
\text { comfortable, and luxurious } \\
\text { impression }\end{array}$ \\
\hline & $\begin{array}{l}\text { The optimistic } \\
\text { family person }\end{array}$ & $\begin{array}{l}\text { Packaging which lists product } \\
\text { composition, expired date, } \\
\text { BPOM permission, and has a } \\
\text { halal label }\end{array}$ & $\begin{array}{l}\text { Unique, colorful, expensive, } \\
\text { including the composition of } \\
\text { raw materials, highlighting the } \\
\text { color, logo, and brand }\end{array}$ \\
\hline & $\begin{array}{l}\text { The change- } \\
\text { expecting lad }\end{array}$ & $\begin{array}{l}\text { Products with simple and } \\
\text { attractive packaging, neat, } \\
\text { beautiful, colorful, not } \\
\text { conspicuous, easy to hold and } \\
\text { unique }\end{array}$ & $\begin{array}{l}\text { Colorful and bright, easy to } \\
\text { handle and consume }\end{array}$ \\
\hline & $\begin{array}{l}\text { Cheerful } \\
\text { humanist }\end{array}$ & $\begin{array}{l}\text { Has a simple, unique design. } \\
\text { Attractive and elegant sight }\end{array}$ & $\begin{array}{l}\text { Unique and colorful, } \\
\text { accentuating the brand and logo }\end{array}$ \\
\hline & $\begin{array}{l}\text { Introvert } \\
\text { wallflower }\end{array}$ & $\begin{array}{l}\text { Has a simple and attractive } \\
\text { form, and fashionable }\end{array}$ & Simple \\
\hline & $\begin{array}{l}\text { The savvy } \\
\text { conqueror/city } \\
\text { slickers }\end{array}$ & $\begin{array}{l}\text { Packaging products that seem } \\
\text { luxurious, brand labels, } \\
\text { innovate, following trends }\end{array}$ & $\begin{array}{l}\text { Unique with bright colors, } \\
\text { content in foreign languages, } \\
\text { ingredient information, produk } \\
\text { companies, durable, futuristic, }\end{array}$ \\
\hline
\end{tabular}




\begin{tabular}{|c|c|c|c|}
\hline Indicators & Characteristics & Survey 2019 & Survey 2004 [9] \\
\hline & & & $\begin{array}{l}\text { following trends, and seem } \\
\text { expensive }\end{array}$ \\
\hline & $\begin{array}{l}\text { The networking } \\
\text { pleasure seeker }\end{array}$ & $\begin{array}{l}\text { Unique, attractive colors, } \\
\text { elegant, accentuating the brand, } \\
\text { luxurious design, comfortable, } \\
\text { durable, elegant, and fantastic }\end{array}$ & $\begin{array}{l}\text { Unique, with striking colors, the } \\
\text { content must be clear, impulse, } \\
\text { elegant, accentuating the brand } \\
\text { and logo, trendy, and expensive }\end{array}$ \\
\hline & $\begin{array}{l}\text { The } \\
\text { spontaneous } \\
\text { fun-loving }\end{array}$ & $\begin{array}{l}\text { Colorful, attractive, luxurious, } \\
\text { and has an elegant design, } \\
\text { includes composition, sealed, } \\
\text { and halal }\end{array}$ & $\begin{array}{l}\text { Unique, colorful, impressed } \\
\text { with luxury, including the } \\
\text { composition of raw materials, } \\
\text { highlighting the brand with } \\
\text { cartoon or velvet packaging, } \\
\text { striking colors }\end{array}$ \\
\hline \multirow[t]{8}{*}{ Communication } & $\begin{array}{l}\text { Established } \\
\text { confidents }\end{array}$ & $\begin{array}{l}\text { Ads that provide information } \\
\text { about product benefits and } \\
\text { provide discounts at several } \\
\text { events. Motivational and } \\
\text { inspirational advertising. Halal } \\
\text { and certified }\end{array}$ & $\begin{array}{l}\text { Communicating charity } \\
\text { activities, highlighting product } \\
\text { character, product } \\
\text { functionalities, product benefits } \\
\text { and values, ATL, and below the } \\
\text { line (BTL) }\end{array}$ \\
\hline & $\begin{array}{l}\text { The optimistic } \\
\text { family person }\end{array}$ & $\begin{array}{l}\text { Explains the benefits, functions, } \\
\text { and usability of the product }\end{array}$ & $\begin{array}{l}\text { Highlighting unique selling } \\
\text { points, structural benefits and } \\
\text { emotional benefits, above the } \\
\text { line and below the line }\end{array}$ \\
\hline & $\begin{array}{l}\text { The change- } \\
\text { expecting lad }\end{array}$ & $\begin{array}{l}\text { Ads provide good, healthy } \\
\text { facilities; there are promos in } \\
\text { stores and supermarkets }\end{array}$ & $\begin{array}{l}\text { Emphasizing emotional } \\
\text { benefits, above the line (more } \\
\text { emphasize especially on promos } \\
\text { at outlets/shopping places) }\end{array}$ \\
\hline & $\begin{array}{l}\text { Cheerful } \\
\text { humanist }\end{array}$ & $\begin{array}{l}\text { Highlighting benefits, } \\
\text { advantages, quality, and } \\
\text { affordable prices }\end{array}$ & $\begin{array}{l}\text { Highlighting functional benefits } \\
\text { and value (low prices), ATL, } \\
\text { and BTL }\end{array}$ \\
\hline & $\begin{array}{l}\text { Introvert } \\
\text { wallflower }\end{array}$ & $\begin{array}{l}\text { A simple ads, cheap, describes } \\
\text { the function of the product in } \\
\text { detail, and at an affordable price }\end{array}$ & $\begin{array}{l}\text { Emphasizing the function and } \\
\text { the price is cheap }\end{array}$ \\
\hline & $\begin{array}{l}\text { The savvy } \\
\text { conqueror/city } \\
\text { slickers }\end{array}$ & $\begin{array}{l}\text { Promotion through SPG, } \\
\text { exposing the functions of the } \\
\text { product and conducting } \\
\text { promotions in various } \\
\text { exhibitions }\end{array}$ & $\begin{array}{l}\text { Communication events that } \\
\text { involve not only emotions but } \\
\text { also supported by the function } \\
\text { of the goods, promotions below } \\
\text { the line, premium prices }\end{array}$ \\
\hline & $\begin{array}{l}\text { The networking } \\
\text { pleasure seeker }\end{array}$ & $\begin{array}{l}\text { Prominence of function and } \\
\text { benefits, quality superiority is } \\
\text { trusted, comfortable, and } \\
\text { trendy. Highlight the functional } \\
\text { product and easy to get }\end{array}$ & $\begin{array}{l}\text { Highlighting functional and } \\
\text { emotive benefits and value } \\
\text { orientation, proportion of above } \\
\text { the line (ATL), and below the } \\
\text { line (BTL) } 80: 20\end{array}$ \\
\hline & $\begin{array}{l}\text { The } \\
\text { spontaneous } \\
\text { fun-loving }\end{array}$ & $\begin{array}{l}\text { There are SPGs or people who } \\
\text { can be asked about these } \\
\text { products, and highlighting the } \\
\text { uniqueness of the product and } \\
\text { its advantages }\end{array}$ & $\begin{array}{l}\text { Highlighting unique selling } \\
\text { points, emotional benefits and } \\
\text { values, ATL and BTL (more } \\
\text { emphasize especially on promo } \\
\text { outlets/shopping places) }\end{array}$ \\
\hline \multirow[t]{2}{*}{ Media } & $\begin{array}{l}\text { Established } \\
\text { confidents }\end{array}$ & $\begin{array}{l}\text { Social media (YouTube, } \\
\text { Facebook, Instagram), radio, } \\
\text { television }\end{array}$ & $\mathrm{TV}$, magazine \\
\hline & $\begin{array}{l}\text { The optimistic } \\
\text { family person }\end{array}$ & $\begin{array}{l}\text { Electronic media such as } \\
\text { television (GTV, MNC, RCTI, } \\
\text { SCTV) and digital (social } \\
\text { media), word of mouth, } \\
\text { exhibition }\end{array}$ & $\begin{array}{l}\text { TV (especially RCTI, SCTV, } \\
\text { Indonesia, TPI), local radio, } \\
\text { national newspapers, tabloids, } \\
\text { magazine }\end{array}$ \\
\hline
\end{tabular}


Dissecting Changes in Consumer Characteristics through Psychographics

DOI: http://dx.doi.org/10.5772/intechopen.89635

\begin{tabular}{|c|c|c|c|}
\hline Indicators & Characteristics & Survey 2019 & Survey 2004 [9] \\
\hline & $\begin{array}{l}\text { The change- } \\
\text { expecting lad }\end{array}$ & $\begin{array}{l}\text { Social media (Facebook, } \\
\text { Instagram, WhatsApp, Twitter, } \\
\text { online magazines, YouTube) } \\
\text { television and radio }\end{array}$ & $\begin{array}{l}\text { TV (RCTI, SCTV, Global TV), } \\
\text { youth segment radio, youth } \\
\text { magazine }\end{array}$ \\
\hline & $\begin{array}{l}\text { Cheerful } \\
\text { humanist }\end{array}$ & Social media and television & $\begin{array}{l}\text { TV (especially RCTI, CTV, } \\
\text { Indosiar, TPI) local radio }\end{array}$ \\
\hline & $\begin{array}{l}\text { Introvert } \\
\text { wallflower }\end{array}$ & $\begin{array}{l}\text { Television, print and online } \\
\text { media, Facebook, WhatsApp, } \\
\text { Instagram }\end{array}$ & $\mathrm{TV}$ and radio \\
\hline & $\begin{array}{l}\text { The savvy } \\
\text { conqueror/city } \\
\text { slickers }\end{array}$ & $\begin{array}{l}\text { Online media, television, } \\
\text { magazines, newspapers }\end{array}$ & $\begin{array}{l}\mathrm{TV} \text {, radio, magazines, } \\
\text { newspapers }\end{array}$ \\
\hline & $\begin{array}{l}\text { The networking } \\
\text { pleasure seeker }\end{array}$ & $\begin{array}{l}\text { Television, online media, } \\
\text { magazines and social media }\end{array}$ & $\begin{array}{l}\text { TV (especially RCTI, SCTV, } \\
\text { Metro, Indosiar, Trans), radio, } \\
\text { national and local newspapers, } \\
\text { magazines }\end{array}$ \\
\hline & $\begin{array}{l}\text { The } \\
\text { spontaneous } \\
\text { fun-loving }\end{array}$ & $\begin{array}{l}\mathrm{TV} \text {, online media, and } \\
\text { magazines }\end{array}$ & $\begin{array}{l}\text { TV (especially RCTI, SCTV, } \\
\text { Metro, Indosiar, Trans), top } \\
\text { segment radio, national } \\
\text { newspapers, top segment } \\
\text { magazines }\end{array}$ \\
\hline \multirow[t]{5}{*}{ Ads } & $\begin{array}{l}\text { Established } \\
\text { confidents }\end{array}$ & $\begin{array}{l}\text { Ads that use social media } \\
\text { accessed by smart phones. It } \\
\text { shows that if they are women, } \\
\text { then they will cover their } \\
\text { genitals and pay attention to the } \\
\text { contents that does not offend } \\
\text { any party so that it can affect } \\
\text { purchasing power }\end{array}$ & $\begin{array}{l}\text { Highlighting the character to } \\
\text { the "Father," showing the } \\
\text { quality and functional products, } \\
\text { endorser is a public figure who } \\
\text { has long been famous, } \\
\text { highlighting the brand, and } \\
\text { product excellence, companies } \\
\text { are advised to bring up } \\
\text { programs on TV }\end{array}$ \\
\hline & $\begin{array}{l}\text { The optimistic } \\
\text { family person }\end{array}$ & $\begin{array}{l}\text { Ads that are attractive, unique, } \\
\text { and not boring and use well- } \\
\text { known endorsers and not only } \\
\text { white }\end{array}$ & $\begin{array}{l}\text { Unique, involving emotions, } \\
\text { endorsers are public figures that } \\
\text { are on the rise/foreign artists, } \\
\text { causing a sense of pride when } \\
\text { using these products, } \\
\text { highlighting the brand, and } \\
\text { product excellence }\end{array}$ \\
\hline & $\begin{array}{l}\text { The change- } \\
\text { expecting lad }\end{array}$ & $\begin{array}{l}\text { Uses a rising public figure. Ads } \\
\text { linked to smart phones and } \\
\text { testimonials that can affect } \\
\text { purchasing strength }\end{array}$ & $\begin{array}{l}\text { Involving emotions, } \\
\text { accentuating teamwork/teams, } \\
\text { smelling unfamiliar, creating a } \\
\text { sense of pride when using these } \\
\text { products, accentuating the } \\
\text { brand. Appeared on TV shows } \\
\text { that involve many people such } \\
\text { as sporting events }\end{array}$ \\
\hline & $\begin{array}{l}\text { Cheerful } \\
\text { humanist }\end{array}$ & $\begin{array}{l}\text { Ads that not only promote } \\
\text { products but also contain } \\
\text { educational meaning, unique, } \\
\text { and use well-known artists. } \\
\text { Ads linked to apps on } \\
\text { smartphones, education, using } \\
\text { artists that can influence } \\
\text { purchasing strength }\end{array}$ & $\begin{array}{l}\text { Unique, engaging emotions, } \\
\text { endorsers are the rising public } \\
\text { figures/artists, creating pride } \\
\text { when using the product, } \\
\text { accentuating the brand, and } \\
\text { product excellence }\end{array}$ \\
\hline & $\begin{array}{l}\text { Introvert } \\
\text { wallflower }\end{array}$ & $\begin{array}{l}\text { Company promotes its products } \\
\text { in the form of ads in various } \\
\text { media, so that people can get to }\end{array}$ & $\begin{array}{l}\text { Thematic advertisements, } \\
\text { endorsers do not need to be } \\
\text { famous }\end{array}$ \\
\hline
\end{tabular}




\begin{tabular}{|c|c|c|c|}
\hline Indicators & Characteristics & Survey 2019 & Survey 2004 [9] \\
\hline & & \multicolumn{2}{|l|}{$\begin{array}{l}\text { know the products they offer, } \\
\text { interesting and not boring. Not } \\
\text { impressed, the expensive, } \\
\text { simple, and attractive }\end{array}$} \\
\hline & $\begin{array}{l}\text { The savvy } \\
\text { conqueror/city } \\
\text { slickers }\end{array}$ & $\begin{array}{l}\text { Highlight the delicacy; highlight } \\
\text { the luxury and excellence of the } \\
\text { product. Online media on } \\
\text { smartphones is very influential } \\
\text { on consumer interest }\end{array}$ & $\begin{array}{l}\text { Thematic, illustrating the } \\
\text { positive side of consumers when } \\
\text { consuming these products, by } \\
\text { highlighting the incomparable } \\
\text { taste of taste }\end{array}$ \\
\hline & $\begin{array}{l}\text { The networking } \\
\text { pleasure seeker }\end{array}$ & $\begin{array}{l}\text { Attractive, engaging emotions, } \\
\text { arousing desire to buy, } \\
\text { endorsers from famous artists, } \\
\text { accentuating brands, and } \\
\text { quality. Advertising is quite } \\
\text { influential on consumer interest } \\
\text { in determining and looking for } \\
\text { work }\end{array}$ & $\begin{array}{l}\text { Unique, involving emotions, } \\
\text { endorsers are public figures } \\
\text { from SES above who are on the } \\
\text { rise/foreign artists, foreign, } \\
\text { causing pride when using these } \\
\text { products, accentuating the } \\
\text { brand and brand excellence and } \\
\text { excellence product }\end{array}$ \\
\hline & $\begin{array}{l}\text { The } \\
\text { spontaneous } \\
\text { fun-loving }\end{array}$ & $\begin{array}{l}\text { Using famous endorse public } \\
\text { figures and hits. Adverts on } \\
\text { smartphone also greatly affect } \\
\text { consumer interest in a product }\end{array}$ & $\begin{array}{l}\text { Using endorsers of public } \\
\text { figures from SES on the rising/ } \\
\text { foreign artists, foreign, giving } \\
\text { pride to the product, } \\
\text { accentuating the brand and } \\
\text { product excellence }\end{array}$ \\
\hline
\end{tabular}

Table 1.

Changing in consumer behavior characteristic.

findings this time where consumers state that products must include passed and certified halal, easy in maintenance and not too expensive. In relevant brands, there are significant changes local brands begin to change consumer behavior. While the strategy to work on the market is more influenced by advertising, discounts and easy to find which is very different from the previous survey which found that the strategy to work on the market places the product in the executive place at a premium price. As with packaging, consumer behavior changes with simplicity, easy to carry, safe, smart, and lawful, which previously featured an elegant brand and logo, included natural raw materials, not perishable and comfortable, and seemed luxurious. Likewise with reemphasizing communication "halal," certified even though there are similarities about the benefits of the product. Changes also exist in terms of media where the magazine is no longer a medium for product delivery but in fact has changed into social media. Meanwhile, advertising also experienced a change where advertisements using social media such as Facebook, YouTube, and Instagram that can be accessed through smartphones are found more effective than television and magazines. The emphasis of halal endorse is resticking in advertisements this time and is very much different from previous surveys which also emphasize on specific, well-known endorsers and appear on a special program on television.

\section{New segments of marketing in Labuhanbatu Regency Indonesia}

Bella [12] wrote in marketer.com that trend technology has higher aspirations than before. How many followers or subscribers have search through mobile phones that are expressive and have a great desire to stand out of Integrate online and 
offline. Hijrah's research results [13] patterns of internet use, the online consumer market consists of three segmentations that are generally commonly used, namely: segmentation in the basic communication pattern, in this segment consumers use the internet primarily to communicate via e-mail, then the trade segment or shopping, in this segment consumers use the internet to surf and browse online stores and the third segments is social relationships and pleasure, in this segment consumers exploit the internet by using interactive features to interact and entertain themselves by chatting, blogging, video streaming, gaming, stalking and downloading. Another case with Sarkum et al.'s research findings [14] on owners, managers, or business owners and SME managers who conduct two marketing systems from offline to online confirms the gap of previous research that the dynamic capabilities, involvement and performance of actors are still a contradiction in between research results. In addition, there is still a gap phenomenon in increasing business performance in SMEs in both offline to online marketing systems.

\section{Discussion}

Consumer typology as outlined in this book chapter is the result of the latest survey that was first held in Labuhan Batu Regency and does not describe the overall character of consumers in Indonesia, but to describe and understand the behavior of Indonesian consumers is important, especially adopting trends in society. The report by Bella [12] states that Judging from MarkPlus Analysis data regarding Customer Attitude/Lifestyle and Facilitating Technology Trends (20122020) there are five Marketers summarized from a number of insights related to Indonesian consumer trends in recent times, including the following:

\section{Multiple aspiration and poverty lines}

Now, Indonesian consumers have higher aspirations than before. Consumers can now feel like a rich person for a moment but can also feel poor instantly. This feeling can be felt so easily and quickly.

\section{2. "F" factor}

The second problem is the "F" factor (Fans/Followers, Friends, and Family driving rate democracy). If people used to think that their assets were how many advertising channels they could reach, now these assets change to how many followers or subscribers they have and how high their engagement is.

\section{Spontaneous discovery}

“About $96 \%$ of Indonesia's population is affected by TVC, 52\% of whom search via mobile phones while watching television," said Yosanova. Nowadays, consumers can easily find something. They can see content on television and at that moment also search for what they see on television via mobile phone. Businesses can respond to this behavior by utilizing sensor technology, ranging from basic ones such as UPC Barcodes or QR Codes to advanced ones such as Location-Based Services, NFC, Digital Wallet, and Augmented Reality.

\section{High demand for customization}

The more advanced the technology the more diverse the desires of consumers. Moreover, young consumers in urban areas are very expressive and have great 
desires to accentuate themselves. The key lies in customer analytics. How often do you hear about Indonesia as a potential market for business people? Maybe this statement is familiar to your ears because almost business players in every industry admit this.

\section{Offline experience still matters}

As the world becomes more digital, consumers increasingly miss the role of offline. For that, the solution is a human interface. Do not underestimate any channel because we cannot see so many opportunities.

So from this, it is necessary for further research, so that what is found can be proven with the predicted trend. In conclusion, Dharmmesta [15] summarizes that understanding the role of consumer behavior research in the context of marketing analysis assumes that we master consumer behavior in the context in which this occurs. If this is done, we can focus on consumer-oriented corporate behavior. Understanding the nature and behavior of companies requires an adequate understanding of consumer choices. The same thing was revealed by Brotspies [16] stating that segmenting business markets is challenging but potentially highly rewarding. An in-depth understanding of how to segment markets is necessary to guide the best decisions leading to profitable targeting. Business markets are changing rapidly due to new technology and a more complex business environment.

\section{Conclusions}

Mapping market segmentation of consumer behavior in Indonesia has changed. Originally, the characteristics of consumer behavior in Indonesia still relied on luxury goods and focused on glamorous brands, changed in quality at an affordable price. It is important to remember that there are new things that did not appear in the results of the previous survey, where the findings of consumers' behavior are requesting the products from upstream to downstream to be certified and halal. This indicates that the wanted products contain religious values and are safe for consumption by consumers in Indonesia.

The segmentation of consumer behavior in advertising and promotional media has also changed, which was originally delivered by television media turned into online media. This has become the basis that promotion and advertising of a product is more effectively done with social media and online.

\section{Acknowledgements}

The author thanks the 6D and E semester students of the Labuhanbatu University Faculty of Economics and Business marketing class who have helped conduct the research for this chapter. LLDikti Region I North Sumatera and Ministry of Research, Technology and Higher Education of the Republic of Indonesia. 
Dissecting Changes in Consumer Characteristics through Psychographics

DOI: $h t t p: / / d x$. doi.org/10.5772/intechopen.89635

\section{Author details}

Sumitro Sarkum

Science and Technology Faculty, Labuhanbatu University, Indonesia

*Address all correspondence to: sumitro.ulb@gmail.com

\section{IntechOpen}

(C) 2019 The Author(s). Licensee IntechOpen. This chapter is distributed under the terms of the Creative Commons Attribution License (http://creativecommons.org/licenses/ by/3.0), which permits unrestricted use, distribution, and reproduction in any medium, provided the original work is properly cited. (cc) BY 


\section{References}

[1] Septiyaningrum R, Lau EA, Yudhyan E. Pengaruh faktor psikografis terhadap keputusan pembelian konsumen matahari department store plaza mulia samarinda. Ekonomia. 2016; 5(2):1-7

[2] Winter E, Russell JT. Psychographics and creativity. Journal of Advertising. 1973;2(1):32-35

[3] Wells WD. Psychographics: A critical review. Journal of Marketing Research. 1975;12(2):196-213

[4] Richard DBA, Becherer C, Lawrence P, Richard M, James PD, Wiley B. Predicting market behavior: Are psychographics really better? Journal of the Academy of Marketing Science. 1977;5(2):75-84

[5] Burns AC, Harrison MC. A test of the reliability of psychographics. Journal of Marketing Research. 1979;16(1):32-38

[6] Szybillo GJ, Binstok S, Buchanan L. Measure validation of leisure time activities: Time budgets and psychographics. Journal of Marketing Research. 1979;16(1):74-79

[7] LI \& P Research. Membedah 8 Karakter Konsumen Indonesia (Survei Psikografis Terlengkap). 2004

[8] DHSA Budiman and Vetriciawizach. Membedah 8 karakter konsumen indonesia: Survey Psikografis Terlengkap, 2008

[9] Membedah 8 Karakter Konsumen Indonesia, SWA.co.id. 2005

[10] SWAOnline. Face of Indonesia oleh Lowe Indonesia, SWA Online Magazine. 2005. Available from: https://swa.co.id/ swa/listed-articles/face-of-indonesiaoleh-lowe-indonesia
[11] Suliyanto. Ekonometrika Terapan:

Teori \& Aplikasi dengan SPSS.

Yogyakarta: ANDI; 2011

[12] Bella A. Seperti Apa Tren Perilaku Konsumen Indonesia? Marketeers. 2018. Available from: https://marketeers.com/ tren-2019-saatnya-ritel-besar-berdaya kan-warung-kecil/

[13] Hijrah L. Segmentasi konsumen pada pasar online di Indonesia. Forum Ekon. 2017;19(2):210-219

[14] Sarkum S, Pramuka BA, Suroso A. Dynamic marketing through engagement_answering the role of marketing functions. International Journal of Marketing, Communication and New Media. 2017;5(9):5-23

[15] Dharmmesta BS. Riset konsumen dalam pengembangan teori perilaku konsumen dan masa depannya. Jurnal Ekonomi dan Bisnis Indonesia. 1999;1:14

[16] Brotspies H, Weinstein A. Rethinking business segmentation: A conceptual model and strategic insights, journal of strategic marketing. Journal of Strategic Marketing. 2017 


\title{
The Media Effect: Implications for Manifesting Maintainable Body Image in the Context of Global Fashion Industry
}

\author{
Arooj Rashid
}

\begin{abstract}
The media 'effect' on consumer behaviour has long been of interest to many researchers. In part, this has been related to how movies, magazines and television programmes portrayed thinness in the nineteenth and twentieth century, a concept which has been consistently emphasised and promoted to women, thus resulting in increased body dissatisfaction. Prior to the existence of media, a curvaceous body was considered as a sign of wealth and an ideal body image. More recently, with the emergence of the Internet, there has been increasing debate over portraying a healthier body image. However, no research to date has addressed the implications of manifesting a maintainable body image in the context of the global fashion industry. Thus, to fill this gap, qualitative ethnographic approach (netnography) of studying online behaviour and consumer perception was undertaken. The chapter briefly outlines the relevance of clothing and the evolution of the ideal body image over the last decade, indicating how the ideal body image has changed, but also shows how different media channels have had an effect using television and social media examples.
\end{abstract}

Keywords: media effect, promotion, body image, global fashion industry

\section{Introduction}

The media effect on the ideal body image has been part of a key debate over the past decade. In part, this is because body image is related to body dissatisfaction and has been linked to several critical physical and mental health problems, such as depression, low self-esteem, bulimia and anorexia [1-3]. More recently, some studies have also started focusing on plus-size body shape, particularly with reference to the shopping experience; however, this study considers the implications for manifesting a maintainable body shape and image, supported by a series of examples based on the media channels and netnography using social media as the key medium of investigation.

\section{Literature review: setting the scene-the changing roles of the ideal body image}

In this social world, clothing has been described as the second skin for a person, reflecting their social status, a concept that is prevalent throughout history [4]. 
When associated with a trend or fashion, it is described as a way of expressing a lifestyle that revolves around activities and interests and it relates to self-expression and covering of the body. The self-expression and covering of the body and the desire to have a body shape are influenced by a range of factors, such as cultural values, impacting on gender, age and social attitude, social norms [5] and media [6]. Furthermore, the desire for a particular body shape or views can also be described as a subjective matter, as everyone has different views and a liking for a particular shape. The views can change depending on the education, experience and understanding of a different lifestyle or the reading habits [7].

In the 1990s until 2010, print media and televised images were the key medium that started to have an increasing effect on the body image, describing thinness as attractive $[4,8]$. For example, exposure to popular fashion magazines that contained messages focused on beauty and fashion (e.g. Elle, Vogue, and InStyle) was correlated with negative moods and higher body dissatisfaction in women [9]. Furthermore, even people in music videos, cartoon characters [10], movie and television actresses, Playboy centrefolds, and Miss America Pageant winners have all become increasingly thinner over the past decades [11-14], impacting young women's body dissatisfaction [15].

Consequently, much attention has been paid towards body image and its impact, particularly in the literature of health, fitness [16] and psychology [3, 8, 17]. In part, this is because body image is described as body dissatisfaction, a desire for thinness and muscularity, self-objectification and the use of more appearance comparisons than non-users [18]. Body image is thus linked to several critical physical and mental health problems, such as depression, low self-esteem, bulimia, anorexia, etc. [3, 19-21]. However, the media's manifesting of a maintainable body image is an under-researched area, in particular with reference to the global fashion industry. Therefore, supported by a series of case studies, qualitative interviews and netnography, this chapter will highlight how the media could manifest a maintainable body image and change consumers' perspective, thereby making a contribution to the literature of marketing and communication.

This chapter focuses on the two key mediums of television and the Internet (social media in particular), indicating how the ideal body image and shape have changed over the years and providing the implications for portraying a more maintainable body shape. The chapter is split into the following sections. Section 1 provides an overview of the chapter, highlighting the gap in the literature it seeks to fill, followed by the articulation of the objective. Section 2 reviews the existing literature with the aim of setting the scene regarding the changes and the recent developments that have occurred in the UK fashion industry. Following this, in Section 2, the ideal body shape in the fashion industry is analysed, starting with a historical overview of how curvaceous was once deemed ideal, followed by how thinness became the new ideal, thereby showing how a maintainable body shape is becoming a new trend in the fashion media. Section 3 discusses the methodology. Section 4 outlines the findings regarding the implications for manifesting a maintainable body image, supported by netnography. Finally, Section 5 concludes and discusses the limitations.

\subsection{Historical overview: evolution of the ideal body shape and the fashion industry}

The concept of the ideal body shape has changed significantly since the early 1900s [22] when a woman with curves was considered as having the ideal body shape. For example, Aphrodite, the goddess of sexual love and beauty, was often portrayed with curves. Furthermore, in the seventeenth and eighteenth centuries, 
a curvaceous figure was also a sign of wealth and a luxurious lifestyle, as only those from a high-class society could afford complex and costly garments [23] and consume meat, milk and alcohol; only a small group of people were representatives of a high-class society. Meanwhile, those with a lower status often remained at home and did household work [24], surviving mainly on plain water, cereals and vegetables $[4,25]$. Consequently, the plump figure at the time was considered as the 'ideal' body shape, with a round stomach being emphasised as a symbol of fertility [26]. Being pale-skinned also represented being rich, as the complexion indicated that people were provided with enough support to do the household work. In other words, women from the rich society could afford servants and/or maids, as opposed to those from the lower classes, who had to work in the sun. The ideal body during this middle age was idealised by the artists of the time [27], as there were no television and magazines at the time. For example, the Flemish painter Paul Rubens was the namesake for the term 'Rubenesque', meaning plump or rounded [28], as he often portrayed women with curvy body types. His contemporary paintings were widely appreciated, essentially because the large body shape represented wealth. To gain that body shape in reality, the corset became a popular undergarment among women in the western world from the late Renaissance until the twentieth century [22]. However, as society's views of a woman's body changed over time, so did the shape and the construction of the corset [22]. For instance, by the nineteenth century, the plump shape figure was replaced by a voluptuous hourglass figure. During this period, the S-bend corset became popular, which reached down the hips and thrust the bust forward. Thereafter, during the twentieth century, a very defined shift towards an increasingly young, athletic and slender body occurred. This shift emerged after the World War I. Women who worked during the war were becoming financially stable and sought social independence, which included driving cars, wearing skimpy dresses and makeup, drinking alcohol and smoking in public. The 1920s saw the rising trend of the flappers, and this reflected the shift towards the western world's desire for a slim physique [22]. This era was also marked as the rebellious 'youth revolutionary era', wherein even older people began copying the trends of younger people.

Following this revolutionary change, the first great depression descended on the economic climate, and with this, the fashion changed, replacing flappers with feminine clothing. During this period, more developments were emerging, i.e. cinema and jazz music became the key source of entertainment. Advertisements in magazines and newspapers started to play an important role, making consumers more beauty conscious [29]. After World War II, many celebrities became iconic role models representing the iconic body shape, such as Marilyn Monroe, Jane Russell and Elizabeth Taylor, while other cultural phenomena such as the Playboy centrefold [30] also added to the portrayal of the curvaceous hourglass figure.

However, the definition of the ideal body image and the media exposure has evolved significantly over the last two decades, particularly relating to body image and eating disturbance in women. Research has shown that media depictions have made a contribution to the current thin beauty ideal by manifesting 'attractive' females (i.e. models, actresses and pop stars). For example, in 2006, British clothing stores started stocking the waiflike size four, which was similar to the US size zero. Fashion retailers such as Banana Republic, initially owned by Gap, also started to advertise size zero clothes on their website in 2006. Furthermore, numerous studies have shown significant correlations between consuming fashion magazines and female body dissatisfaction and a desire for thinness $[6,9]$. Tiggemann and Zaccardo [31] confirmed that mass media has been a powerful and pervasive force, and there is extensive research that indicates the link between media exposure and body dissatisfaction [32], supported by meta-analyses [33] and experimental evidence $[34,35]$. Across these studies, there is reliable evidence of a 
small-to-moderate negative effect of the thinness ideal portrayed within magazines and television programmes. More recent correlational research has established a similar link between time spent on the Internet and body dissatisfaction in adult and adolescent women [16, 36-38].

The present study focuses on exposure to television and social media (Facebook and Instagram), indicating the implications for manifesting a maintainable body shape.

\subsection{The television industry}

In the literature on communication and psychology, many researchers have shown increasing interest towards television viewing, particularly concerning gender views [34, 39, 40] and its impact on eating disorders [41]. For example, Wille et al. [39] examined television viewing, fat stereotyping and body shape standards and suggested that because young children are more likely than adolescents or adults to model viewed behaviour, it is reasonable to expect that young children would model the ideal body shape they observe on television. On the other hand, Botta [42] examined television images and adolescents' views and suggested that the existence of the ideal thin body shape does have an impact on television viewers. In part, adolescents are prone to be more vulnerable to the thin-promoting messages because they are at a time in their lives when they may be seeking outside information to form a self-identity $[21,43]$.

Furthermore, the literature on promotion and communication also looks into commercialisations [44] and reality shows, suggesting how the television and film industry can be driven by commercialisations and entertainment content such as television programmes [44, 45]. Vazquez et al. [44] denote that characters in commercials and/or hosts and characters in reality shows often become celebrities in their own right and celebrities are a popular means of promoting fashion products such as lifestyle trends and beauty or clothing products, e.g. Piers Morgan on Good Morning Britain and the characters of Love Island. Adding to this, Manwaring [46] contributes how, in 2010, Heidi Montag of The Hills discussed her plastic surgery procedure in one of the Time Magazine interviews, highlighting how she used to bring pictures of movie stars to the plastic surgeon to request a body part to be made. More recently, in Good Morning Britain, the actress Katie Price revealed she had received 16 surgeries, which can be considered an addition. In addition, on November 8, 2018, Good Morning Britain portrayed a show where a plus-size woman modelled some lingerie. In the show, the reality show star Helen Wood suggested that models should be skinny. However, no research to date has explored the implications of manifesting a maintainable body shape.

This section focused on television, particularly reality shows. The next section will focus on social media, due to the number of bloggers promoting a healthy lifestyle.

\subsection{The social media effect}

Previously, many authors have shown increasing interest towards airbrushing and the computerised edited photos displayed in magazines and television advertisements [23] and their impact on young women [18, 38, 47]. Recently, several authors have suggested that Facebook should be deemed as one of the most popular social media platforms for young women $[18,38]$, who tend to spend around $2 \mathrm{~h}$ per day on Facebook. Social media sites Facebook and Instagram are particularly known to impact young women because they allow users to create public and/or semipublic personal profiles by providing their information and uploading their photos [48]. These two sites are also known for allowing users to edit their photos; for example, 
Instagram has several filtering options, which users can use before uploading a photo or video $[16,38]$. The filtering option and the opportunity to 'like' and make comments on the photo have resulted in individuals feeling the pressure to enhance the photo prior to displaying it, which has implications for social comparison and self-presentation $[49,50]$. Social presentation is a process derived from the evaluative presence of other people and other viewers. In other words, individuals compare themselves with the cultural ideal of beauty and thinness presented in the media, which can result in dissatisfaction with their own body [51].

However, this social presentation can also have a positive effect, particularly when many fitness and lifestyle bloggers are trying to make a positive impact, such as Carly Rowena, Lazy Girl Running and Kayla Itsines, promoting ways to remain healthy yet making it seem fun. Furthermore, some authors have also started to show interest in the effect of plus-size models displayed in the media [52], finding how viewers consider plus-size to be more realistic as opposed to the ideal thin body shape. However, manifesting a maintainable body image in the media remains as an under-researched area, particularly as displaying plus-size models on television is starting to increase the debate on unhealthy body figures and consumers' lack of preference.

\section{Methodology}

To investigate the media's effect on consumer attitude and preferences towards a maintainable body image, this study took an ethnographic approach of studying online behaviour, described by Kozinets [53] as 'netnography' [54]. Netnography applies ethnographic approaches to online behaviour, drawing on publicly accessible online social interactions in the same way that an ethnographer observes human behaviour in the field [53]. In other words, it refers to studying and understanding the consumption-related aspects of customers' lives online [53,55]. Similar approaches have been used previously in qualitative studies of online health-related discussion boards. The sampling framework was consumers' interaction and engagement on social media platforms, reading a large number of comments expressing a range of reactions to changes in body shape and images posted on Facebook (FB) and/or Instagram (IG), particularly focusing on online pure-play retailers, plus-size clothing retailers, sport brands and international online retailers. Other sources, such as Good Morning Britain and BBC, were also observed on the social media platforms to examine whether consumers had similar responses or whether they differed.

Populations from which social media research data are drawn cannot be generalised. Accordingly, it should be acknowledged that views expressed on social media platforms are those of the general audience, representing a wide range of audience that either finds the body shape negative or positive, empowering the society.

In doing so, it was deemed important to observe how many comments were made and how frequently certain reactions were made by the consumers in order to identify how a post and an image on the media affected the audience. To generate a manageable data sample, there was a pragmatic need for three body shapes or images that the study could focus on. Thus, using an opportunistic approach [54], this study focused on three key body shapes: 'super-skinny', 'plus-size' and 'fitness built body shape'. Fitness built body shape particularly focused on the body shape and size that can be managed after childbirth or similar. To attain a maintainable body shape, fitness routine is imperative, as is healthy food intake, etc., and this is very rarely promoted on the media including social media unless a personal trainer has created a personal brand and has numerous followers on Instagram and social media.

In terms of the choice of social media platform, Facebook was deemed important because numerous sources [54] have indicated that there are about 2.41 billion 
monthly active users as of the second quarter of 2019, with Facebook being the largest social network worldwide. Active users are those who have logged in on Facebook and have carried out the following activities: follow a group or organisation, 55\% of US baby boomers and senior survey respondents followed a group or organisation in 2013, and $40 \%$ of those respondents posted and watched videos [56]. Statistics from 2017 [57] indicate that $40.7 \%$ of users accessed Facebook to communicate with a group. A group can involve a TV programme, BBC news and other pages related to world affairs. Communication with the group is the largest factor for this study, as this is where the data is generated from. However, another activity that also contributed towards generating the findings was 'read, watch and share news about the world', with $52.03 \%$ of users logging in on Facebook and carrying out this activity as per 2017 statistics [58].

Instagram was another social media platform that was chosen to observe online behaviour using the netnography approach, with about 60 million photos being uploaded to Instagram every day [59]. Instagram was deemed as a useful platform as this new digital environment has especially empowered women to market themselves as brands. Furthermore, the most important aspect is the extensive growth of fitness bloggers manifesting fitness routines (i.e. Carly Rowena, Lazy Girl Running) and the increasing exposure of fashion brands using plus-size models, i.e. Boohoo, JD Williams, Shein, Next, etc. Using a diverse range of primary social sites ensured the availability of triangulated perspectives that also delivered data on the convergence and divergence of a maintainable body image $[1,60]$.

The data were then thematically evaluated using the template analysis method [61], observing online pure-play retailer, sport retailers, plus-size fashion brand and an American fashion retailer. Meanwhile, the content analysis approach was dismissed, which involves counting the amount of time frequency of a variable or a word that occurs and is considered useful when identifying the similarities and differences within the structure of the research subject [62]. As a result, the data for this study were evaluated through a systematic recognition of themes or meaning patterns, which is referred to by [61] as a meaning-making process. Due to reasons of confidentially, posts that were observed have not been identified [63].

\section{Findings}

This section will present the findings concerning consumers' perspectives on various body shapes and the implications for maintaining a body image, using information drawn from the netnography that involved observing Facebook and Instagram. The findings are structured in these two themes: manifesting plus-size body image and the portrayal and effect of skinny models; however, more results and findings can be found in Appendix 1.

\subsection{Manifesting plus-size body image}

As mentioned in Section 3.4, social presentation involves individuals comparing themselves with the culturally ideal body shape, which has previously been associated with 'thin', resulting in individuals with dissatisfaction towards their own body. From observing the social media platforms, it appears that fashion industry has actively started producing product lines that are tailored for the plus-size market but has also started promoting plus-size models on social media, e.g. Boohoo, Very and JD Williams. However, plus-size clothing and models are yet not promoted as frequently as skinny models are; for example, on Instagram (IG), Boohoo only posts 2 or 3 photos of plus-size out of 31 or more photos posted in a week's turnaround. 
From the netnography it is evident that promoting plus-sizes on social media is done for positive reasoning, for example, a female respondent on social media argued that 'the fashion industry can not neglect the plus size'.

Furthermore, throughout history, the plus-size body shape has been considered as the ideal body shape and one that represented wealth. However, from the findings it is evident that this is no longer the case in the current society. For example, the posts on social media appear to be fostering debate about how plus-size is associated with being unhealthy and obese, e.g. a male respondent on Facebook stated that 'big is beautiful is a deluded phrase and that plus-size can lead to stroke diseases and cancer' (FB, 2018). Another female respondent has also stated on a different Instagram photo that 'obesity is unhealthy and promoting it is irresponsible' (IG, 2019). While some comments are also empowering, i.e. 'She is nailing it', and 'She is beautiful, this would suit my curves' (IG, 2019).

In contrast to the negative comments, another female respondent argued to a post on social media platform stating 'plus-size is not obese but an average size of a women; however, the fashion industry is compelled to use this terminology as anorexia size is deemed to be average' (FB, 2018). This indicates how the use of the terminology 'plus-size', 'unedited' and clothing' can create a buzz on social media.

Further buzz was spotted on social media when a fashion online pure-play retailer was slammed for photoshopping and adding using 'butt pads' on models in 2018 to promote its plus-size collection. Comments were mainly related to 'how the image represented a plus-size, even though the model was fairly slim or skinny' $(\mathrm{FB}, 2018)$ and would have been referred to as such by many.

In another social media news, a sport brand was accused recently by the journalist for promoting obesity using a plus-size mannequin. The general public defended the fashion brand by stating on social media platform 'that the marketing reflects their body' and 'Happy that the brand is doing this for normal people like myself, inspiring to get the health back on track'.

Furthermore, more comments were made relating to how rather than individuals supporting plus-size, they could perhaps encourage a fitness regime. A similar debate rose on September 20, 2018, when the host Piers Morgan criticised that 'Cosmopolitan was promoting dangerous and wrong image' by manifesting an American model who weighed around $300 \mathrm{lbs}$ (21.4 st) and was a US size 22 [64], associating this with obesity.

\subsection{The portrayal and effect of skinny models}

Since the 1990s, with the discovery of Kate Moss, the fashion industry has been extensively involved in promoting skinny models. Over the years, the trend of skinny has led to an impact on younger girls and women, who have taken her mantra of 'nothing tastes as good as skinny feels' far too far.

More recently, the fashion industry has started making some effort by taking the action of banning super-skinny models in some countries. For example, France banned anyone with a body mass index (BMI) below a certain level from working as a model. Posts related to this generally received positive feedback on Facebook. For example, an individual on Facebook commented, 'Thank god we need to see healthy women on the runways' (FB, 2015). However, majority of the posts relating to France banning super-skinny models have not received as many comments as would a post on social media manifesting a negative image or an image that is not generally approved by the general public. For example, the majority of the posts relating to France banning super-skinny models have only had a few individuals sharing the post, and some have had no comments at all. 
On the one hand, Instagram appears to have more actively engaging customers, criticising or making comments about skinny models, by making comments such as 'does it come with a body to match', 'I better look like this in it or I'll be fuming', 'I have stuck to the diet 2 days now', and 'Why don't I look like this' (IG, 2019). These comments were particularly made under pictures with models wearing bikini.

Furthermore, the maintainable body shape is often found to be questionable as it is not clear whether it relates more closely to a plus-size or super-skinny. However, there are many fitness influencers who are now trying to promote a healthy lifestyle and a maintainable body shape suggesting different fitness routines e.g. squads and other legs work out, followed by some empowering comments e.g. 'Need to build my strength to rock this!!' (IG, 2018), This is awesome I am just starting my fitness journey and seeing your post gave me the extra kick, I need too stick to it! (IG, 2017). On the other hand, some influencers are also trying to promote 'being confident in embracing the curves', which could be due to several reasons, e.g. postpartum and hormones, while empowering them to try staying healthy by fitness routines. This is also deemed to contribute towards mind and soul.

By observing the social media platform, it is has emerged that these influencers are not only promoting a fitness routine but are also suggesting how one should feel confident about their body shape, manifesting maintainable body shape and image. For example, a UK London-based fitness trainer 'Carly Rowena' often posts stories on Instagram about 'how people should do as they feel and how they should feel confident about their body shape and skin' (IG Story, 2019). Furthermore, the comments made under the personal blog are also fairly positive, encouraging and empowering and, thus, indicating the influence of a personal brand on consumers as opposed to clothing brands.

Another known fitness trainer 'Kayla Itsines' is an Australian blogger with many followers, who promotes the emotional rollercoaster one may go through when trying to maintain a lifestyle and body shape after giving birth. Their posts are followed by many positive comments and baby posts by other individuals, spreading words of wisdom and positivity.

\section{Conclusion and discussion}

The focus of this chapter was on the implications of manifesting a maintainable body shape in the global fashion industry. The data was drawn focusing on two. Each channel is supported by data analysed using netnography, drawing information from comments made in the online communities on Facebook and Instagram.

The study particularly focused on the two body shapes of plus-size and skinny models. In part, this was important, as skinny models were traditionally preferred in the global fashion industry, whereas now plus-size models are being more frequently promoted.

Based on the findings drawn from social media platforms, it is evident that some consumers on online communities are not fully happy with the promotion of plus-size model, even if a fashion brand shares only so often, e.g. one photo a week. While many health studies have identified how being overweight can be due to health issues such as hormones or DNA, comments on social media indicate that this should not be manifested on the mass media as this may not be a true representation or a maintainable body shape, contradicting previous studies that argued similarly about thinness [33-35] (see Figure 1 as an example). From a brand's perspective, it can be assumed that due to consumer's critics and comments 


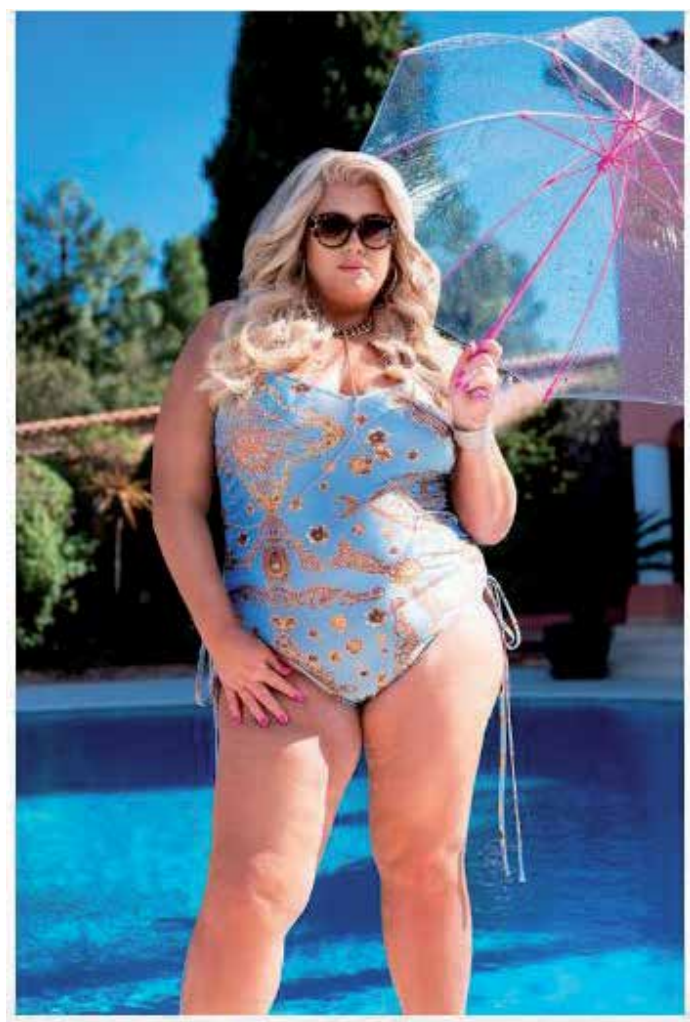

Figure 1.

An example of the portrayal of plus-size model online. Source: Boohoo.com (2019).

related to health issues and obesity, fashion brands are pushed to share only limited photos on plus-size or using slimmer models to promote plus-size clothing, which is also resulting in complaints and shaming the media. However, these results vary depending on the type of fashion brand it is, i.e. if the brand is recognised for selling plus-size, then the negative comments are less as opposed to if brand is targeting a young, slimmer body shape. Thus, a contribution can be made to the literature of promotion, communication and body image.

From the findings and comments, it appears that social media platform has many active users and majority of the active users follow fashion brands to view the latest trend, i.e. new bikini, new dresses, etc. However, some of the comments under the post relates to wanting a particular body shape or if wearing a particular clothing product would make them slimmer, etc., going in hand with previous studies (see $[6,9])$. Adding to this, majority of the comments do relate to wanting to buy the product as well. This indicates how a body shape and clothing products impact consumer's behaviour and cognitive thinking process. However, from the findings, it was also evident that clothing products such as bikini's often trigger more comments related to body shape and image as oppose to those with a dress (see Figure 2). Thus, this can also contribute to literature of fashion promotion and clothing.

Finally, it can be concluded that plus-size body image gains more negative attention as opposed to slimmer body shape, despite that fashion industry is constantly criticised for promoting skinner fashion model. However, there are now personal influencers on Instagram that are collaborating with sport fashion brands to promote their fitness product line and maintainable body shape and image. 


\subsection{Limitations}

The study has identified several challenges and limitations in doing this research. The findings can only be generalised according to the size of the sample. For instance, the process of identifying suitable posts on social media was deemed to be difficult as not many are directly related to fashion. Secondly, the process can be time-consuming as it involves going through comments and extracting patterns and meaning while looking at different sources and comments.

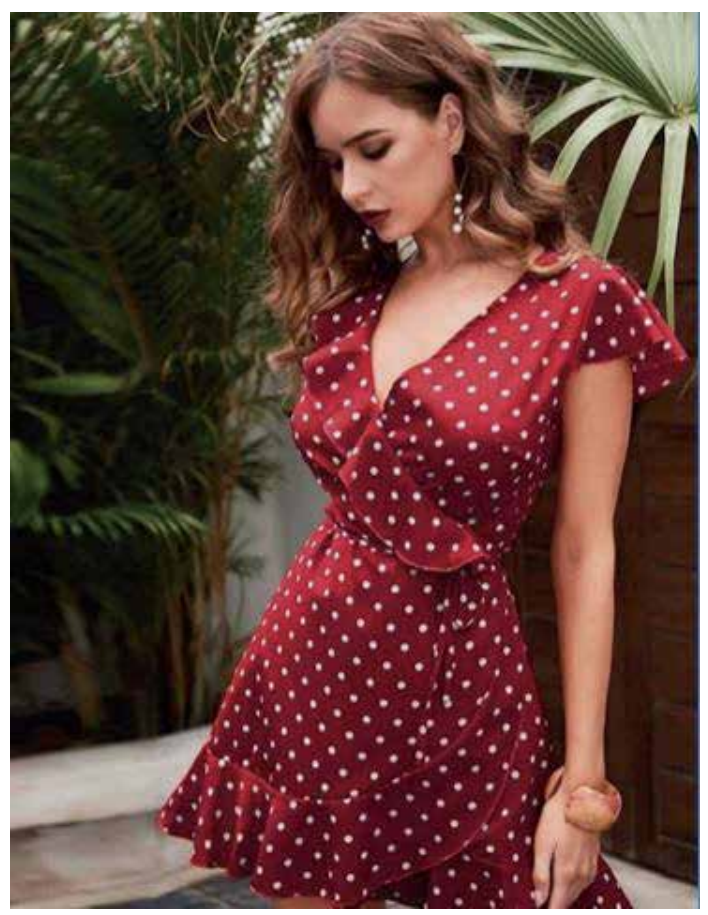

Figure 2.

An example of a product that attracts less comments related to body shape and more related to the actual product. Source. Shein.com, 2019.

\section{Appendix 1}

\begin{tabular}{|c|c|c|}
\hline Participant & $\begin{array}{l}\text { Body shape and } \\
\text { image }\end{array}$ & Key views \\
\hline Plus-size & $\begin{array}{l}\text { Instagram, } \\
\text { 2019; Facebook, } \\
2018\end{array}$ & $\begin{array}{l}\text { - The fashion industry cannot neglect the plus-size (IG, 2019) } \\
\text { - Big is beautiful is a deluded phrase and that plus-size can lead to } \\
\text { stroke diseases and cancer (FB, 2018) } \\
\text { - Confidently Unhealthy (IG, 2019) } \\
\text { - hey lovely We were scrolling through and think you're } \\
\text { absolutely gorgeous (-) DM us, we'd love to collaborate (Fashion } \\
\text { brand, IG, 2019) } \\
\text { - Do you think it's ok to put obese models?? They are shocking } \\
\text { and looks very unhealthy (IG, 2019) } \\
\text { - Chubby but it's really beautiful (IG, 2019) } \\
\text { - I'm all for body confidence being a } 14 \text { myself I like to see curvy } \\
\text { models but this looks like it doesn't fit she needs the bigger size } \\
\text { (IG, 2019) }\end{array}$ \\
\hline
\end{tabular}


The Media Effect: Implications for Manifesting Maintainable Body Image in the Context... DOI: http://dx.doi.org/10.5772/intechopen.89239

\begin{tabular}{|c|c|c|}
\hline Participant & $\begin{array}{l}\text { Body shape and } \\
\text { image }\end{array}$ & Key views \\
\hline Skinny models & $\begin{array}{l}\text { Instagram, } \\
\text { 2019; Facebook, } \\
2018\end{array}$ & $\begin{array}{l}\text { - Can I have her body please thanks (IG, 2019) } \\
\text { - I better look like this in it or I'll be fuming } \\
\text { - How do regular people wear this?! (IG, 2019) } \\
\text { - Thank god we need to see healthy women on the runways } \\
\text { - I have stuck to the diet } 2 \text { days now. } \\
\text { - Why don't I look like this } \\
\text { - too much for holiday? Will I look just like her in this? Haha (IG, } \\
\text { 2019) } \\
\text { - It might look better if she had sum meat on her bones (IG, } \\
\text { 2019) } \\
\text { - obviously not for swimming, just to show off by the pool (IG, } \\
2019 \text { ) } \\
\text { - if only I had this body lmao (IG, 2019) } \\
\text { - If only I have a body shape like that (IG, 2019) }\end{array}$ \\
\hline $\begin{array}{l}\text { Maintainable } \\
\text { body }\end{array}$ & $\begin{array}{l}\text { Instagram, 2017, } \\
\text { 2019; Facebook, } \\
\text { 2018, } 2019\end{array}$ & $\begin{array}{l}\text { - You look awesome but you always have :- }{ }^{*} \text { beautiful inside and } \\
\text { out } \\
\text { - You're killing it! So happy for you and your progress! (IG, 2017) } \\
\text { - This is awesome I am just starting my fitness journey and seeing } \\
\text { your post gave me the extra kick in the back, I need too stick to } \\
\text { it! (IG, 2017) } \\
\text { - It's not just the exercise...that girl looks like that because she's } \\
\text { very careful of what she is eating. Everyone can do these } \\
\text { exercises everyday but won't look like that if their diet is not } \\
\text { 'perfect'. Plus I believe she was born with a slim figure and now } \\
\text { she has perfected it (IG, 2019) } \\
\text { - Thank god we need to see healthy women on the runways (FB, } \\
\text { 2015) } \\
\text { - Need to build my strength to rock this!! (IG, 2018) }\end{array}$ \\
\hline
\end{tabular}

\section{Author details}

Arooj Rashid

Nottingham Trent University, Nottingham, England

*Address all correspondence to: arooj.rashid@ntu.ac.uk

\section{IntechOpen}

(C) 2019 The Author(s). Licensee IntechOpen. This chapter is distributed under the terms of the Creative Commons Attribution License (http://creativecommons.org/licenses/ by/3.0), which permits unrestricted use, distribution, and reproduction in any medium, provided the original work is properly cited. (cc) BY 


\section{References}

[1] Dion D, Mazzalovo G. Reviving sleeping beauty brands by rearticulating brand heritage. Journal of Business Research. 2016;69(12):5894-5900. DOI: 10.1016/j.jbusres.2016.04.105

[2] Fardouly J, Willburger BK, Vartanian LR. Instagram use and young women's body image concerns and self-objectification: Testing mediational pathways. New Media \& Society. 2017;20:1380-1395. DOI: $10.1177 / 1461444817694499$

[3] Grabe S, Hyde JS, Lindberg SM. Body objectification and depression in adolescents: The role of gender, shame, and rumination. Psychology of Women Quarterly. 2007;31:164-175. DOI: 10.1111/j.1471-6402.2007.00350.x

[4] Apeagyei PR. Significance of body image among female UK fashion consumers: The cult of size zero, the skinny trend. International Journal of Fashion Design, Technology and Education. 2008;1(1):3-11. DOI: $10.1080 / 17543260701867697$

[5] Kozinets R. Click to connect: Netnography and tribal advertising. Journal of Advertising Research. 2006;46:279-288. DOI: 10.2501/ S0021849906060338

[6] Cusumano DL, Thompson JK. Body image and body shape ideals in magazines: Exposure, awareness, and internalization. Sex Roles. 1997;37:701721. DOI: 10.1007/BF02936336.pdf

[7] Grossberg L, Ellen W, Charles W. Media Making: Mass Media in a Popular Culture. Thousand Oaks, CA: Sage; 1998

[8] Heinberg LJ, Thompson JK. Body image and televised images of thinness and attractiveness: A controlled laboratory investigation. Journal of Social and Clinical Psychology. 1995;14:325-338. DOI: 10.1521/ jscp.1995.14.4.325

[9] Swiatkowski P. Magazine influence on body dissatisfaction: Fashion vs. health? Cogent Social Sciences. 2016;2:1-17

[10] Grabe S, Ward L, Shibley-Hyde J. The role of the media in body image concerns among women: A meta-analysis of experimental and correlational studies. Psychological Bulletin. 2008;134:460-476. DOI: 10.1037/0033-2909.134.3.460

[11] Garner DM, Garfinkel PE, Schwartz D, Thompson M. Cultural expectations of thinness in women. Psychological Reports. 1980;47:483-491. DOI: $10.2466 /$ pr0.1980.47.2.483

[12] Klein H, Shiffman KS. Thin is 'in' and stout is 'out': What animated cartoons tell viewers about body weight. Eating and Weight Disorders. 2005;10:107-116. DOI: $10.1007 /$ BF03327532

[13] Morris A, Cooper T, Cooper P. The changing shape of female fashion models. International Journal of Eating Disorders. 1989;8:593-596. DOI: 10.1002/1098-108X(198909) 8:5<593:: AID-EAT2260080511>3.0.CO;2-H

[14] Spitzer BL, Henderson KA, Zivian MT. Gender differences in population versus media body sizes: A comparison over four decades. Sex Roles. 1999;40:545-565. DOI: 10.1023/A:1018836029738

[15] Myers T, Crowther J. Social comparison as a predictor of body dissatisfaction: A meta-analytic review. Journal of Abnormal Psychology. 2009;118:683-698. DOI: $10.1037 /$ a0016763 
The Media Effect: Implications for Manifesting Maintainable Body Image in the Context... DOI: http://dx.doi.org/10.5772/intechopen.89239

[16] Tiggemann M, Miller J. The Internet and adolescent girls weight satisfaction and drive for thinness. Sex Roles. 2010;63:79-90. DOI: 10.1007/ s11199-010-9789-z

[17] Johnson F, Wardle J. Dietary restraint, body dissatisfaction, and psychological distress: A prospective analysis. Journal of Abnormal Psychology. 2005;114:119-125. DOI: 10.1037/0021-843X.114.1.119

[18] Fardouly J, Diedrichs PC, Vartanian LR, Halliwell E. The mediating role of appearance comparisons in the relationship between media usage and self-objectification in young women. Psychology of Women Quarterly. 2015;39(4):447-457. DOI: $10.1177 / 0361684315581841$

[19] Moreno-Domínguez S, Servián-Franco F, Reyes del Paso GA, et al. Images of thin and plus-size models produce opposite effects on women's body image, body dissatisfaction, and anxiety. Sex Roles. 2019;80:607-616. DOI: 10.1007/ s11199-018-0951-3

[20] Neumark-Sztainer D, Wall M, Larson NI, Eisenberg ME, Loth K. Dieting and disordered eating behaviors from adolescence to young adulthood: Findings from a 10-year longitudinal study. Journal of the American Dietetic Association. 2011;111:1004-1011. DOI: 10.1016/j. jada.2011.04.012

[21] Strasburger VC. Adolescents and the Media: Medical and Psychological Impact. Thousand Oaks, CA: Sage; 1995

[22] Howard J, Ginsburg A. The History of the 'Ideal' Woman and Where that has Left Us. 2018. Available from: https://edition.cnn.com/2018/03/07/ health/body-image-history-of-beautyexplainer-intl/index.html [Accessed: 10 July 2019]
[23] Holmqvist K, Frisén A. I bet they aren't that perfect in reality: Appearance ideals viewed from the perspective of adolescents with a positive body image. Body Image. 2012;9:388-395. DOI: 10.1016/j.bodyim.2012.03.007

[24] Sigmund E, Sigmundová D, Badura P, Kalman M, Hamrik Z, Pavelka J. Temporal trends in overweight and obesity, physical activity and screen time among Czech adolescents from 2002 to 2014: A National Health Behaviour in School-aged Children Study. International Journal of Environmental Research and Public Health. 2015;12:11848-11868. DOI: 10.3390/ijerph120911848

[25] Cohen R, Newton-John T, Slater A. The relationship between Facebook and Instagram appearancefocused activities and body image concerns in young women. Body Image. 2017;23:183-187. DOI: 10.1016/j. bodyim.2017.10.00

[26] Fallon A. Culture in the mirror: Sociocultural determinants of body image. In: Cash T, Pruzinsky T, editors. Body images: Development, Deviance, and Change. New York: Guilford; 1990. Available from: https://psycnet.apa.org/ record/1990-98350-004

[27] Grogan S. Body Image:

Understanding Body Dissatisfaction in Men, Women and Children. London/ New York: Routledge; 1998

[28] Auwera JV, Rubens PP, Balis A. Rubens: A Genius at Work: The Works of Peter Paul Rubens in the Royal Museums of Fine Arts of Belgium Reconsidered. Lannoo Uitgeverij; 2007

[29] Hill D, Hill G. As Seen in Vogue: A Century of American Fashion in Advertising (Costume Society of America Series). Texas: Texas Tech University Press; 2007 
[30] Mazur A. U.S. trends in feminine beauty and over-adaption. The Journal of Sex Research. 1986;22:281-303. DOI: 10.1080/00223980209604820

[31] Tiggemann M, Zaccardo M. Exercise to be fit, not skinny: The effect of fitspiration imagery on women's body image. Body Image. 2015;15:61-67. DOI: 10.1016/j.bodyim.2015.06.003

[32] Lin L, Reid K. The relationship between media exposure and antifat attitudes: The role of dysfunctional appearance beliefs. Body Image. 2009;6:52-55. DOI: 10.1016/j. bodyim.2008.09.001

[33] Levine MP, Murnen SK. Everybody knows that mass media are/are not [pick one] a cause of eating disorders: A critical review of evidence for a causal link between media, negative body image, and disordered eating in females. Journal of Social and Clinical Psychology. 2009;28:9-42. DOI: 10.1521/ jscp.2009.28.1.9

[34] Wood K, Baker J, Thompson J. Body image dissatisfaction in pre-adolescent children. Journal of Applied Developmental Psychology. 1996;17:85-100. DOI: 10.1016/ S0193-3973(96)90007-6

[35] Groesz LM, Levine MP, Murnen SK. The effect of experimental presentation of thin media images on body satisfaction: A meta-analytic review. The International Journal of Eating Disorders. 2002;31:1-16

[36] Blair CE, Kelly NR, Serdar KL, Mazzeo SE. Does the Internet function like magazines? An exploration of image-focused media, eating pathology, and body dissatisfaction. Eating Behaviors. 2012;13:398-401. DOI: 10.1016/j.eatbeh.2012.06.003

[37] Tiggemann M, McGill B. The role of social comparison in the effect of magazine advertisements on women's mood and body dissatisfaction. Journal of Social and Clinical Psychology. 2004;23:23-44. DOI: $10.1521 /$ jscp.23.1.23.26991

[38] Tiggemann M, Slater A. NetGirls: The Internet, Facebook, and body image concern in adolescent girls. International Journal of Eating Disorders. 2013;46:630-634

[39] Wille E, Gaspard H, Trautwein U, Oschatz K, Scheiter K, Nagengast B. Gender stereotypes in a children's television program: Effects on girls' and boys' stereotype endorsement, math performance, motivational dispositions, and attitudes. Frontiers in Psychology. 2018;9:2435. DOI: 10.3389/ fpsyg.2018.02435

[40] Anschutz D, Engels RCME, Becker ES, Van Strien T. The effects of TV commercials using less thin models on young women's mood, body image and actual food intake. Body Image. 2009;6:270-276. DOI: 10.1016/j. bodyim.2009.07.007

[41] Harrison K. Television viewing, fat stereotyping, body shape standards, and eating disorder symptomatology in grade school children. Communication Research. 2000;27:617-640. DOI: $10.1177 / 009365000027005003$

[42] Botta RA. The mirror of television: A comparison of Black and White adolescents' body image. Journal of Communication. 2000;50:144-159

[43] Ashbach C. Media influences and personality development: The inner image and the outer world. In: Zillmann D, Bryant J, Huston AC, editors. Media, Children and the Family: Social Scientific, Psychodynamic and Clinical Perspectives. Hillsdale, NJ: Erlbaum; 1994. pp. 117-128

[44] Vazquez D, Cheung J, Xu X. Investigating Chinese audience- 
The Media Effect: Implications for Manifesting Maintainable Body Image in the Context... DOI: http://dx.doi.org/10.5772/intechopen.89239

consumers responses towards TV carácter based fashion related social media content. International Journal of Business and Globalisation. 2018;22(1):53-73. DOI: 10.1504/ IJBG.2019.097389

[45] Homer PM. Product placements: The impact of placement type and repetition on attitude. Journal of Advertising. 2009;38(3):21-32. DOI: 10.2753/JOA0091-3367380302

[46] Manwaring A. Reality television and its impact on women's body image [Online Theses and Dissertations]. Paper 50; 2011. Available from: https:// encompass.eku.edu/etd/50

[47] Kim JW, Chock MT. Body image 2.0: Associations between social grooming on Facebook and body image concerns. Computers in Human Behavior. 2015;48:331-339. DOI: 10.1016/j. chb.2015.01.009

[48] Fardouly J, Vartanian LR. Negative comparisons about one's appearance mediate the relationship between Facebook usage and body image concerns. Body Image. 2015;12:82-88. DOI: $10.1016 /$ j.bodyim.2014.10.004

[49] Chua THH, Chang L. Follow me and like my beautiful selfies: Singapore teenage girls' engagement in selfpresentation and peer comparison on social media. Computers in Human Behavior. 2016;55:190-197. DOI: 10.1016/j.chb.2015.09.011

[50] Webb JB, Butler-Ajibade P, Robinson SA. Considering an affect regulation framework for examining the association between body dissatisfaction and positive body image in Black older adolescent females: Does body mass index matter? Body Image. 2014;11:426-437. DOI: 10.1016/j. bodyim.2014.07.002

[51] Bell. Social media and female body image [Unpublished master's thesis]. Bridgewater, Massachusetts:

Bridgewater State University;

2016. Retrieved from: http://

vc.bridgew.edu/cgi/viewcontent.

cgi?article=1137\&context=honors_proj

[52] Beale K, Malson H, Tischner I.

Deconstructing "real" women: Young women's readings of advertising images of "plus-size" models in the UK. Feminism and Psychology. 2016;26(3):1-9. DOI: $10.1177 / 0959353516639616$

[53] Kozinets R. On netnography: Initial reflections on consumer research investigations of cyberculture. In: Alba J, Hutchinson W, editors. Advances in Consumer Research. Vol. 25. Provo, UT: Association for Consumer Research; 1998. pp. 366-371

[54] Elvey R, Voorhees J, Bailey S, Burns T, Hogson D. GPs' views of health policy changes: A qualitative 'netnography' study of UK general practice online magazine commentary. British Journal of General Practice. 2018;68(671):441-448. DOI: $10.3399 /$ bjgp18X696161

[55] Heinonen K, Medberg G. Netnography as a tool for understanding customers: Implications for service research and practice. Journal of Services Marketing. 2018;32(6):657-679. DOI: 10.1108/JSM-08-2017-0294

[56] Numbers of Monthly Active Facebook Users Worldwide as of 2nd Quarter 2019 (in millions) [Internet]. 2019. Available from: https://www. statista.com/statistics/264810/numberof-monthly-active-facebook-usersworldwide/

[57] Most Popular Social Networks Activities of Baby Boomer and Senior Internet Users in the United States in 2013 [Internet]. 2013. Available from: https://www.statista.com/ statistics/309228/boomer-senior-socialnetwork-activities/ 
[58] Most Popular Facebook Activities in the United States as of October 2017 [Internet]. 2017. Available from: https:// www.statista.com/statistics/275788/ share-of-facebook-user-activities/

[59] 16 Statistics to Show Why Instagram Marketing is Crucial [Internet]. 2019. Available from: https://oursocialtimes. com/16-statistics-to-show-whymarketers-need-instagram/

[60] Speziale HS, Streubert HJ, Carpenter DR. Qualitative Research in Nursing: Advancing the Humanistic Imperative. China: Lippincott Williams and Wilkins; 2011

[61] King N, Horrocks C. Interviews in Qualitative Research. London, UK: Sage Publications; 2010

[62] Dwyer L, Gill A, Seetaram N. Handbook of Research Methods in Tourism: Quantitative and Qualitative Approaches. Cheltenham, UK: Edward Elgar Publishing; 2012

[63] Rashid A, Barnes L, Warnaby G. Management perspective on country of origin. Journal of Fashion Marketing and Management. 2016;2(2):230-244

[64] Sherdian E. Piers Morgan Tells Plus-Size Model Tess Holliday She 'Needs Help' as Bitter Feud Continues [Internet]. 2018. Available from: https:// www.mirror.co.uk/3am/celebrity-news/ piers-morgan-tells-plus-size-13280115 


\title{
Marketing Communication and Promotion in Health Services
}

\author{
Aykut Ekiyor and Fatih Altan
}

\begin{abstract}
Marketing communication in the health sector is the communication of the products or services produced by health organizations to the potential users and convincing them about the benefits to be provided. Although the use of the concept of health services and promotion is controversial, promotional activities in health services are different from promotion activities in other sectors. Public relations (PRs) rather than advertising are in the forefront of promotion activities in the health sector. Health institutions, especially hospitals, are highly complex systems both in terms of services provided and organizational structure. The aim of this study is to reveal the importance of promotion activities in health care and their different aspects from other sectors. In this context, the international literature on health marketing was searched, and this content was created. As a result, the aim of promotion in health services is not to direct the patient unnecessarily to consumption but to inform patients, to convince them about benefits of the services, and to facilitate their service delivery by increasing their participation in the service process. If promotion tools are used correctly in health care, they can help in early diagnosis of many diseases.
\end{abstract}

Keywords: promotion, marketing, health care, communication, consumer

\section{Introduction}

Modern marketing requires much more than developing a good product or service, making attractive pricing, and making available products or services accessible. Businesses have to communicate with existing and potential stakeholders and the public. Businesses in public communication; be going to say what, how, where, when, how often, and to whom should well planned. Consumers are actively using communication tools such as hundreds of cable and satellite broadcasts, thousands of magazines and newspapers, and millions of web pages ([1], p. 579).

Marketing communication is a very popular topic today. No field of marketing is changing as fast and drastic as marketing communication. Because with the emergence of concepts such as online, mobile, and social media marketing, customer participation is increasing day by day ([2], p. 425).

Marketing communication (promotion) can be defined as the process of information transmission between the seller and the potential buyer or other people ([3], p. 344). In other words, marketing communication can be defined as the means used by the company to communicate with customers and other stakeholders ([2], p. 426). Promotion is one of the marketing mix; the right products and/or services 
include those described to the target audience, which can be reached at the right place and at the right price. Promotion activities should be compatible with other elements of the marketing mix and differentiation and positioning strategies, requiring serious work for the target audience ([3], p. 344).

Marketing communication is defined as the method in which enterprises try to inform and persuade consumers about the products or services they sell directly or indirectly. It represents the brand and voice of the business. These methods are also the means for the enterprise to establish dialog and develop relationships with consumers. It contributes to customer value by strengthening customer loyalty. In addition to increasing sales, it affects brand value. It creates a brand image by keeping the brand in mind and contributes to brand equity ([1], p. 580). Building good customer communication requires more than developing a good product or service, making attractive pricing, or making it available to customers. When developing products or services, businesses should involve consumers in this process, communicate their value suggestions to their customers, and leave communication to chance ([2], p. 425).

The importance of marketing communication has increased in recent years for various reasons. Increasing products and services are seen as the similarity of their life cycles at maturity stage. As a result, it is seen that it is very difficult to make a difference in terms of distinguishing the brands related to the specific qualities of products and services. Marketing communication elements contribute to the creation of points that make a difference. In markets with uncertainty and complexity, marketing communication becomes very important for enterprises to gain competitive advantage ([4], p. 823).

\section{Communication process}

Communication is basically the transmission of information. In order for communication to take place, the information must have some things in common with both the sender and the recipient. There must be a common understanding of symbols, words, and images used to convey information. Accordingly, communication can be expressed as a sharing of meaning ([5], p. 430). Figure 1 shows the communication process in detail.

As shown in Figure 1, business communication process starts with sources. Source is defined as a person, group, or organization attempting to share a

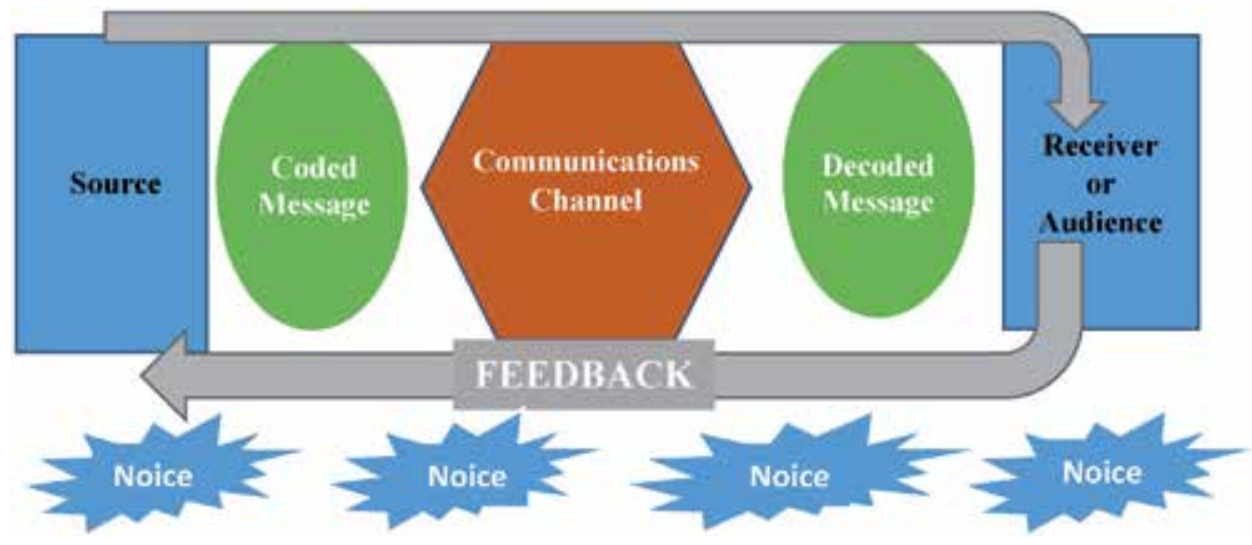

Figure 1.

Communication process. Source: Ref. ([6], p. 568). 
meaning with the audience or recipient. Source can be a salesperson explaining the characteristics of the TV to the customer in a TV store or a TV manufacturer advertising through the TV to inform the consumer. A strategy can be developed to increase the communication efficiency of a source. For example, a sales person can influence a customer's decision by comparing it to the competitor's products. Receiver or audience is a person, group, or organization that decodes a coded message sent by the source. Coding is the process by which a source converts a series of signs or symbols representing meaning, ideas, or concepts to convey the message. The source has to take into account some features of the receiver or audience when encoding a message. In order to share the meaning, it is necessary to use the signs and symbols of source appropriate to the receiver or audience. Research shows that messages from a source are more convincing when addressing a person's character. For this reason, enterprises should recognize their target audience and carry out promotional activities accordingly ([6], pp. 568-569).

Source selects and uses a communication means, i.e., a communication channel, which carries the encoded message from the source to the viewer or receiver to share a coded message with the receiver or audience. Communication tools include printed media (newspapers, magazines, etc.), visual media (TV, etc.), and digital communication. Although TV is used as the most common means of communication today, it is becoming widespread in digital channels. Decoding is defined as the conversion of signs and symbols into concepts or ideas. Noise arises from the different perceptions of the encoded message as a result of the decoding step. In other words, it is defined as anything that reduces the clarity and accuracy of communication. Sometimes the communication channel also causes noise. Examples include the difficulty in transmitting from radio or television or the slow Internet connection speed. Feedback is defined as the response of recipient or viewer to a decoded message. Therefore, communication refers to the circular process between the source and the receiver or audience ([5], pp. 431-432).

In order to carry out a healthy communication with the target audience, the marketing manager should pay attention in establishing a marketing communication, and some system issues should be taken into consideration [7]:

- Target audience should be well-defined.

- Targets and the reaction to be created in the target audience should be determined.

- Communication should be designed, and the most appropriate communication channel (media) should be selected.

- Provide feedback and measure results.

- Factors preventing communication should be eliminated.

\section{Promotion mix}

The promotion mix-also called marketing communication-consists of advertising, public relations, personal selling, sales promotions, direct sales, and digital marketing used to contact with consumers, establish relationships with customers, and persuade customers. These promotional means are described as follows ([2], pp. 425-426): 
- Advertising: It may be defined as any nonpersonal paid element used for the promotion of ideas, goods, or services through a particular financier.

- Sales promotions: Short-term incentives used to promote the purchase or sale of a product or service.

- Personal selling: Personal customer interactions to attract customers, make sales, and establish relationships with customers.

- Public relations: Establishing good relations with various groups in order to create a good corporate image and deal with and prevent negative rumors or situations related to the business.

- Direct and digital marketing: The goal is to interact directly with individual customers or customer communities, both for instant response and to make customer relationships more permanent.

According to Keller ([4], pp. 820-821), marketing communication tools consist of many tools. These tools are media advertising, direct response and interactive advertising, place advertising, store signage and point of purchase advertising, trade and consumer-oriented promotions, event marketing and sponsorships, marketingoriented public relations and publicity, and personal selling. Media advertising is carried out by using media tools such as TV, radio, newspapers, and magazines. Direct response and interactive advertising are carried out by using channels such as direct mail, online advertising, and telephone solicitation. Place advertising is carried out by using media tools billboards and bulletins, posters, transit ads, and cinema ads. Store signage and point of purchase advertising is carried out by the means of external store signs, in-store shelf signs, shopping cart ads, and in-store radio and TV. Trade and consumer-oriented promotions are carried out by using promotions such as trade deals and buying allowances, display and advertising, trade shows, cooperative advertising, samples, coupons, premiums refunds/rebates, contests/ sweepstakes, promotional games, bonus packs, and price-off deals. Event marketing and sponsorships are carried out through activities such as sponsorship of sporting events and sponsorship of arts, fairs, and festivals.

There are clear differences between the challenge marketers face 20-30 years ago and today's challenges. One of the most important of these changes is the increase in the variety and number of communication options that marketers can use to reach consumers. In recent years, there have been some changes in marketing communication. These are fragmentations of traditional advertising media and the emergence of new (non-traditional) media, publicity, and other means of communication. These developments pushed marketing communication to use different communication methods. One of these methods of communication is any form of communication initiated by any marketer who is directly or indirectly related to the brand. As indicated in Table 1, communication options are often categorized by broad communication options or media types ([4], pp. 820-821).

Marketing communication is a concept beyond the abovementioned promotion mix elements. Many elements such as the design of the product, price, shape and color of the package, and the stores where the product is sold convey something to the buyers. Therefore, although the promotion mix is the main task and communication activity of the enterprise, it should be coordinated to make a big impact with all marketing mix elements such as the product, price, and distribution promotion ([2], p. 425). 


\begin{tabular}{|c|c|}
\hline \multirow[t]{3}{*}{$\begin{array}{l}\text { Advertising for } \\
\text { consumer markets }\end{array}$} & $\begin{array}{l}\text { National advertising } \\
\text { It can be expressed as advertising by large companies nationwide or in many regions } \\
\text { of the country. Most advertisements for well-known companies and brands seen in } \\
\text { the major national or regional media can be considered in this category. The goals } \\
\text { of national advertisers are to inform or remind consumers about the characteristics, } \\
\text { benefits, advantages, or uses of the company or brand and to create an image for } \\
\text { consumers to tend to purchase }\end{array}$ \\
\hline & $\begin{array}{l}\text { Retail/local advertising } \\
\text { It can be expressed as a type of advertising by retailers or local merchants to encourage } \\
\text { consumers to shop in a particular store, use a local service, or become a customer of } \\
\text { a particular business. The advertisements in this category apply to certain protective } \\
\text { activities such as price, working hours, service, atmosphere, and image or variety of } \\
\text { commercial products. }\end{array}$ \\
\hline & $\begin{array}{l}\text { Primary versus selective demand advertising } \\
\text { Primary versus ads are ads designed to promote demand for the overall product class } \\
\text { or the entire industry. Selective demand advertising is intended to create a demand for } \\
\text { the goods or services of a particular company } \\
\text { The advertiser's brand is the market leader, and the primary demand is focused on } \\
\text { advertising. Primary demand ads are used as part of promotional strategies for a new } \\
\text { product to be accepted in the market }\end{array}$ \\
\hline \multirow[t]{3}{*}{$\begin{array}{l}\text { Advertising for } \\
\text { business and } \\
\text { professional } \\
\text { markets }\end{array}$} & $\begin{array}{l}\text { Business-to-business advertising (B2B) } \\
\text { B2B advertising is an advertisement used to persuade owners to purchase industrial } \\
\text { goods or services for their companies. Industrial goods can be either raw materials } \\
\text { or machines used to produce another product. Insurance, travel, and health services } \\
\text { are considered in this category. In addition, these goods may also be products used } \\
\text { in the production of other goods and used to assist in the conduct of a company's } \\
\text { business (office equipment, computers, etc.). Insurance, travel, and health services } \\
\text { are considered in this category }\end{array}$ \\
\hline & $\begin{array}{l}\text { Professional advertising } \\
\text { Professional advertising targets professionals such as physicians, lawyers dentists, and } \\
\text { engineers to encourage them to use a company's product in their } \\
\text { business operations. In addition, it can be used to encourage professionals to } \\
\text { recommend the use of a company's product by end users }\end{array}$ \\
\hline & $\begin{array}{l}\text { Trade advertising } \\
\text { It targets marketing channel members such as wholesalers, distributors, and } \\
\text { retailers. The goal is to encourage channel members to stock, promote, and sell the } \\
\text { manufacturer's branded products to their customers. }\end{array}$ \\
\hline
\end{tabular}

Source: Ref. ([8], p. 20).

Table 1.

Advertising classification.

Basic forms of marketing communication include traditional mass advertising (TV, magazines, etc.), online advertising (websites, emails, text messaging, etc.), sales promotions (samples, coupons, discounts and premium products, etc.), stores and point of sale signs, direct mail supply, marketing-oriented public relations and promotional presentations, sponsorship, and sales personnel presentation. All of these communication and media tools constitute promotion components ([9], p. 4).

Marketing managers should understand that many sales promotion activities will not produce results in a short time. Therefore, long-term sales promotion objectives of enterprises should be long enough to predict real success. It should also have the patience to create a concrete market position that will continue its sales promotion strategy. In addition, creativity is at the forefront of sales promotion activities ([7], p. 230). 


\section{Advertising}

In-line with economic, political, technological, and social changes, one of the promotional tools used by organizations to reach their target audiences is advertising ([7], p. 230). Advertising is the transmission of information about products and services to an audience through mass media, including TV, radio, the Internet, newspapers, magazines, direct mail, outdoor shows, and signs on public transport. Advertisements change as consumers' habits of mass media use change. Nowadays, businesses use digital media extensively to maintain their existence and maximize their impact. Advertisements that appeal to even smaller audiences are designed. The use of traditional advertising tools is decreasing day by day ([6], pp. 574-575). Individuals and organizations use advertising to promote their products, services, ideas, and problems to people. The flexibility of the advertisements allows it to reach a larger audience and can focus on a small and undefined group. For example, while Quizno's ads focus on a wide range of potentially fast-food customers, from children to adults, advertising for Gulfstream jets focuses on a much smaller and more specific target market. On the other hand, outdoor advertising related to the dangers of passive smoking is used to increase awareness among children. The more people can focus on people at a low cost per person, the more economical it is ([5], p. 437).

There are limitations as well as what the ad can achieve. Consumers often perceive the ad as a guest who comes in without being invited. When they see the advertisement, consumers try to avoid the advertisement by turning the pages of newspapers and magazines, muting the sound of TV and radio, and dealing with other issues during the advertisement. In particular, ads that interrupt consumers' favorite programs may have negative effects on consumers. Another negative aspect of mass media advertising is that it reaches more people than the actual target audience. For example, TV broadcasting of cosmetic products for women does not only reach women consumers but also the audience of men and children ([10], p. 540).

Advertising varies from sector to sector. Businesses, retailers, etc. that sell products or services to the consumer market are usually rely on advertising to communicate with the target audience. However, advertising increases the demand for products or services. Advertising is also widely used by businesses competing in professional markets to reach existing or potential customers. For example, marketers help raise awareness about businesses and their products and services, guide sales force, build confidence in customers' products and services, and create an appropriate environment ([8], pp. 18-19).

The objectives of the advertisement can be grouped into three categories. These are information, persuasion, and reminder. In addition, advertising can be done for the following purposes ([7], p. 233):

- Introducing new products to the market and introducing them or entering the new market section

- Encouraging the use of products and services used by a small audience for large masses by creating purchasing motivation

- Giving information about the usage of the product

- To create brand preference

- To create company image and brand loyalty 
- Helping the sellers by explaining the company and the properties of the goods

- Expanding the volume of goods or services to maintain demand

- Reaching individuals or groups that vendors cannot reach directly

- Correcting prejudices and false and negative impressions

- Educating consumers

- Reminding consumers where to buy products or services

- Keeping the product alive in the minds of consumers during periods of low sales

In order to achieve the goals of the advertisement, decisions should be made on how to make advertising campaigns and how many budgets will be allocated and which media will be used and the effectiveness of the advertisement.

In Table 1, advertising is expressed in two main categories. These are advertising for business and professional markets and consumer markets. Advertising for consumer markets, national advertising, local/retail advertising, and primary versus selective demand advertising, and advertising for business and professional markets, business-to-business advertising (B2B), professional advertising, and trade advertising, are examined separately.

Direct-to-consumer advertising (DTCA) is one of the most controversial issues in the health sector. Historically, prescription drug and medical device advertising in the United States were primarily intended for professional individuals and organizations rather than consumers, but in 1997 the Food and Drug Administration (FDA) guided direct marketing guidelines for pharmaceutical companies for advertising in mass media. With this published guide, DTCA became widespread [11]. Figure 1 shows the increase in direct consumer expenditures in the pharmaceutical sector. In 1997, advertising spending reached a record level following the FDA's guidance on changing DTCA rules.

With the increasing knowledge of healthcare users about product and service selection, health service providers, health insurance companies, pharmaceutical companies, and medical device manufacturers have recognized the benefits of advertising for end users. This has been the result of the rapid increase in healthcare expenditures in the United States [12].

The most important factor among the benefits of advertising in health services is the power of individuals to make decisions about their health. Individuals will be able to know how, where, and when to use medical products and services when their knowledge of health is increased through advertising. On the other hand, the most important concern about advertising is the difficulty of the relationship between the physician and patient. The clinical decision-making role of the physician may potentially be diminished [13].

\section{Personal selling}

It is a paid form of personal communication that persuades customers to inform and purchase products in the event of change. Personal selling is the most commonly used promotional activity for high-quality products such as home, 
car, electronic products, and furniture in inter-business and consumer markets ([5],p. 438). Personal selling includes face-to-face communication with the customer. Unlike advertising, promotion, and other nonpersonal forms of communication, there is a direct interaction between the buyer and the seller. This twoway communication means that the seller receives information about the buyer instantly and makes a sales presentation in accordance with his specific needs and problems ([14], p. 491). The most effective way to establish meaningful dialog with the customer is personal selling. Businesses use personal selling to promote new products, services, brands, and facilities. Because it is less costly than consumer advertisements, low-budget businesses use personal selling to increase their influence in the market ([15], p. 291).

Personal selling provides all kinds of customer relationships from real sales relationships to personal friendships. An effective salesperson protects the interests of customers to solve long-term relationships by solving customer's problems. After the sales presentation, even if the buyer gets the answer "no, thank you," he usually feels the need to listen and respond. Despite the fact that advertising can be increased and decreased, it is difficult to change the size of the sales force, which requires a longer-term agreement than advertising. It is the most expensive promotion tool of businesses. Therefore, businesses spend three times the amount they spend on advertising ([2], p. 441).

Personal selling often includes very fast and precise feedback as the sales presentation can be evaluated according to customer reactions. If the sales staffs notice that the sales presentation is inappropriate from the customer feedback, they can change the message. Although it is one of the elements of personal selling promotion mix, it is not a direct part of marketing communication in many companies. Personal selling is often referred to as a different management department that is not included in the advertising or marketing department. In addition, various promotional elements such as media advertising, digital marketing, and sales promotions should be conducted in coordination with personal selling ([8], p. 27).

Home visits of health personnel in institutions that provide preventive health services in health services are examples of personal selling. During these visits, health personnel determine the health needs of the household and invite individuals to the health institution. Another example is the medical representatives of pharmaceutical companies. Medical agents inform physicians about the medicines offered by the company and try to convince physicians to prescribe them. In therapeutic health services, personal selling is not meaningful due to the characteristics of health services.

In addition, sales activities for pharmaceuticals and medical supplier representatives for physicians, insurance providers for consumers, biomedical planting suppliers for health institutions are examples personal selling in health services [16].

\section{Sales promotions}

Sales promotions are defined as an activity or material that directly provides incentives and means of product or service, provides added value, and provides incentives to sellers and customers, such as free samples, games, discounts, sweepstakes, contests, premiums, coupons and so on. Sales promotion should not be confused with promotion. Sales promotion is only part of the promotion, which is a much more comprehensive field of activity. Marketers spend more on sales promotions than ads. In addition, sales promotion is an area that grows faster than advertising ([5], p. 440). 
With the incentives provided by sales promotions, there is a rapid support for sales. The impact of such promotional activities is very short-lived. In addition, the excessive use of certain incentives may damage the brand image ([14], p. 431).

Sales promotions attract the attention of the consumer and engage the consumer and provide strong incentives for the purchase. Customers are rewarded with sales promotions to react quickly. Advertising activities tells consumers to "buy our products or services," and sales promotions say "buy our products or services now." Ensuring long-term brand preference and building customer mass is not as effective as advertising or personal selling ([2], p. 440).

Sales promotion in health services is a more modest tool than other marketing communication mix elements. An example of sales promotions in health care is the free presentation of things such as pens, calendars, and similar objects with the logo of the institution or organization [17]. In addition, participating in trade fairs, professional meetings, and conferences of the personnel working within the health institution may be a means of sales promotion. This provides an opportunity for people who are difficult to reach, such as physicians or health managers, to display the product/service offered by the institution or institution. While it can be quite difficult to reach the physician in the healthcare institution, such sales promotions can be easily reached with the target audience [16].

\section{Public relations}

Many of the promotional elements focus on the company's customers. But for businesses-suppliers, employees, shareholders, media, educators, potential investors, government, and society in general—other stakeholders are also very important. In order to communicate with customers and other stakeholders, public relations is an important concept. Public relations are a wide range of communication efforts used to establish and maintain positive relationships between an organization and its stakeholders. Establishing a positive relationship with one or more stakeholders contributes to the sales, profitability, and survival of the entity ([6], p. 576).

Public relations include corporate promotion, seminars, publications, lobbying, and charitable donations ([14], p. 450). Public relations activities in international enterprises are generally carried out by independent departments within the headquarters of the companies. The public relations department basically carries out the following activities ([7], p. 250; [14], p. 450):

- Relations with the media

- Product and company presentation

- Recognizing the target audience

- Improving image and communication in enterprises

- Lobbying and sociocultural activities

- Sponsorship

- Image studies

- Participation in fairs and exhibitions 
- Consultancy

- Charitable donations

- Seminars

- Publications

Publicity is one of the most important elements of public relations. The information about a product, service, or organization is transmit to the society through media channels. The three main tasks of the promotion department are to respond to information requests from the media, to provide information to the media about important events in the organization, and to encourage the media to communicate the information and perspective of the organization to the society. The dissemination of information can take place through news, as well as through long-length articles, interviews, and public meetings (conferences, seminars, etc.). Regardless of which of these tools is used to communicate information to society, promotion has three important features. These ([14], p. 451) are the following:

1. High reliability of the message to be transmitted to the society.

\section{No direct media costs.}

\section{No broadcast controls.}

Since the transfer of corporate information to the society through the media is done through a media and not directly by the institution, it needs to have higher reliability. In addition, the fact that there is no direct cost of the information to be transmitted to the society does not mean that it has no cost. Taking part in a media tool's newsletter, organizing a conference or taking part in an interview requires a particular organization. This organization is carried out through agencies. In addition, there is no guarantee that the news will be published unlike advertisements, as there is no fee for information to be transmitted through the media. The decision is made by the editors of the media organization. Table 2 shows the issues that may be news for a business.

The most important feature of health institutions in terms of public relations is that it addresses all public sectors and serves people of all ages and genders. In addition, another feature of public relations units is the requirement of health institutions to protect patient interests. More importantly, all health managers, doctors, nurses and staff have effective elements in their activities [18].

There are important objectives of public relations in health institutions. These objectives can be expressed as the public disclosure of the service policies of the health institution and the adoption of these policies by the public, ensuring that the activities carried out by the organization are welcomed by the society in a positive manner, learning what is thought about the organization by the society, and providing cooperation with the public [19].

\section{Direct marketing}

Direct marketing, involves "an interactive system of marketing that uses one or more advertising media to effect a measurable response and/or transaction." The main difference between direct marketing and other promotion tools is that 


\begin{tabular}{ll}
\hline Marketing issue & Financial issues \\
\hline New products & Financial statements \\
Research & Acquisitions \\
Breakthroughs: future new products & Sales/profit achievements \\
Large orders/contracts & Personal issue \\
Sponsorships & Training awards \\
Price changes & Winners of company contests \\
Service changes & Promotions/new appointments \\
New logos & Success stories \\
Export success & Visits by famous people \\
& Reports of interviews \\
\hline Production issues & General issues \\
\hline Productivity achievements & Conferences/seminars/exhibitions \\
Employment changes & Anniversaries of significant events \\
Capital investments & \\
\hline Source: Ref. ([14], $p$. 452). & \\
\hline
\end{tabular}

Table 2.

Issues with potential news value.

marketers target a direct audience to deliver a message for specific needs [16]. Direct marketing is one of the fastest growing areas of the US economy. Traditionally, direct marketing is not considered among the promotion mix elements. However, in many companies, it is considered as an element of promotion mix as it is an integral part of marketing communication ([8], p. 62).

Direct marketing is the introduction of products to customers through the use of telephone, the Internet, or nonpersonal media, enabling customers to purchase them through these tools ([5], p. 409). According to the American Direct Marketing Association's definition, direct marketing is defined as "an interactive (bi-directional) marketing system that uses one or more advertising tools to induce measurable response and/or activity from anywhere, or to influence customers' ideas." ([7], p. 252). For example, a business can announce through letters, brochures, mail, etc. to its specified target audience. It can even make it easier for the target audience to purchase the product or service by adding an order form related to the products and services to the specified promotional tools. In the globalizing world, changing customer profiles and changing lifestyles of people, the change and spread of the technology used in marketing and the spread of customer-oriented marketing understanding have led to the spread of direct marketing ([10], p. 65). Direct marketing provides the opportunity to supply products in new ways. In addition, direct marketing differs from other methods of communication and usually requires a direct response. This allows quantitative assessment of the effectiveness of many direct marketing campaigns ([14], p. 481).

Businesses use direct marketing to tailor their offerings and content to the needs and interests of narrowly defined groups or individual buyers. In this way, customer participation is ensured, brand community is formed, and sales are realized ([2], p. 512).

Health institutions can use direct marketing to inform customers about existing or new services or to propose special offers to customers. In this communication method, the recipient should have the attention to open the e-mail. The advantage of e-mail compared to direct mail is that it reaches the target in a very short time and has a minimum entitlement [20].

Telemarketing, a direct marketing method that consumers are familiar with, is a method which is based on periodical communication of health institution with 
consumers via call center informing them about the products/services produced offered. In other words, it is a direct marketing method used to reach potential customers regarding various services and programs. In addition, telemarketing is more expensive than e-mail, but it is more effective in attracting the patient to the healthcare facility [16].

Promotion mix elements consist of advertising (newspaper, magazine, TV etc.), personal selling (personal communication with customers), direct marketing (e-mail, telemarketing etc.), digital communications (social media, blog, website etc.), sales promotion (coupons, sample product, discount etc.), publicity (corporate identity, institutional advertising etc.), and sponsorship. All of these tools have typical strengths and weaknesses. Direct marketing has strengths such as personalizing communication, facilitating the measurement of short-term activities, sustaining communication with customers through periodic contact, and minimizing competitors' access to activities performed. In contrast, the low response rate and direct marketing activities targeting the poor may cause consumer disturbance and weaknesses ([14], p. 432).

\section{Health services and promotion}

Today, health institutions have become consumer-centered and aim to produce high-quality services at reasonable prices. Therefore, health marketing has become increasingly competitive all over the world [21].

Health care and promotion are two concepts that have been difficult to think together. It is always debated which messages will be given to people with health problems related to a hospital or similar health institution. Moreover, it is not clear when the need for health services will arise. It is natural that healthy person does not pay much attention to a doctor, hospital, or health care. Because of these features, it is possible to say that there are different dimensions of promotion in health services ([7], p. 252). Promotion is a remarkable issue in health services. In broad terms, the product/service, price, distribution, promotion, and human element in the marketing mix constitute the means of communication. The promotion function in any service organization consists of efforts to communicate with old, current, and future customers. Customers must be aware of the service provided by the organization. Promotion includes promotional activities such as advertising, sales promotion, and personal selling. Health institutions do not carry out aggressive promotion activities. They believe that word of mouth communication is more reliable [21].

It is necessary to address the image of the organization before discussing how promotion activities can be carried out in healthcare facilities. For example, is the organization innovative, dynamic, and using advanced technology, or is it more traditionally committed? Answering these questions is very important. The answers to these questions vary depending on the type of service offered by the health institution and the market conditions in which it operates. Some questions need to be answered about how to manage promotional activities. These ([22], p. 136) are the following:

- What image does the hospital or unit currently have?

- What kind of image do health managers want?

- What kind of image do patients and applicants want, and what will be most comfortable?

- What images are there in other local hospitals or units? 
Promotion indicates how health enterprises will provide information and training to the market on their products and services. The information process includes public relations, advertising, and other activities. For example, the publicity function can be used for present and new services, management of the crisis situation, partnership with organizations, and promotion of the new method that will lead the future of the organization. In addition, it is advertised to the masses on billboards by service providers to inform potential patients, healthcare organizations, and local employers the type of product or service, the cost status of the organization, and ease of transportation ([7], p. 253). In addition, five activities that are generally used as promotion or communication tools in health institutions are mentioned (Figure 2).

While some of the promotion mix elements (brochures, etc.) mentioned in Figure 3 require low cost and coordination, others (advertisements, exhibitions, public relations, sponsorship, etc.) are applications with higher budgets. As it can be understood from the statements, it is necessary to use many elements together in which only one or two promoter elements will not contribute much to the establishment ([22], p. 138).

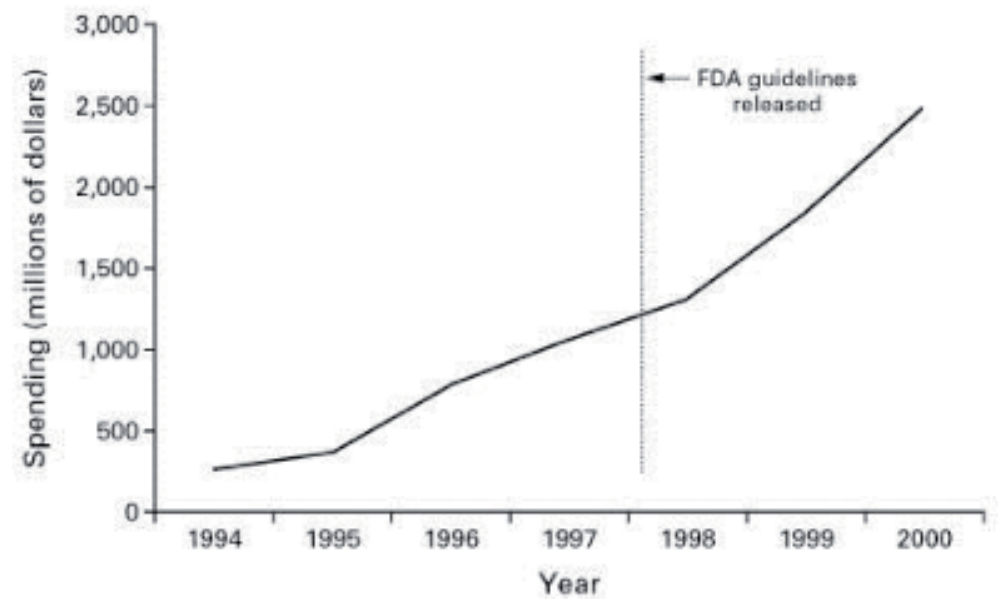

Figure 2.

The growth of pharmaceutical DTCA spending. Source: [12].

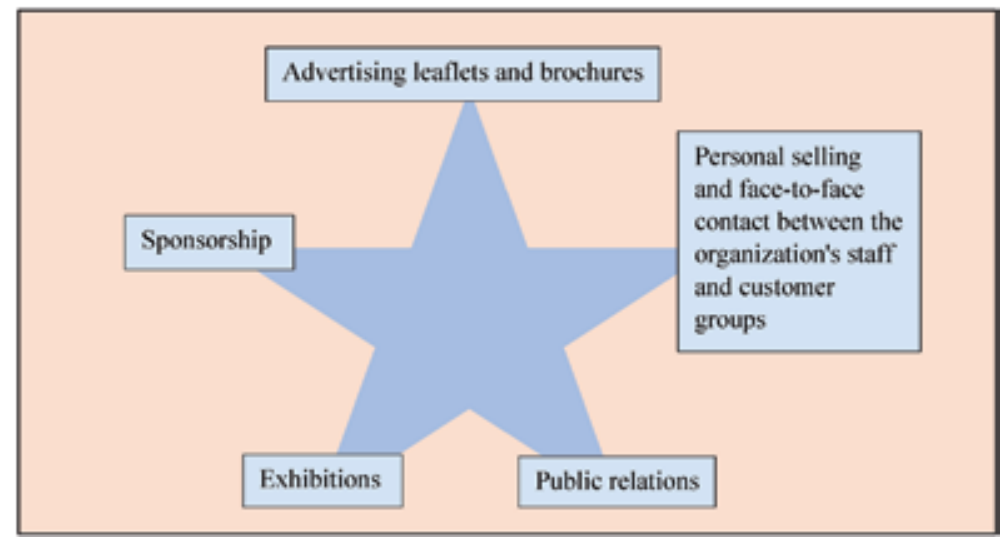

Figure 3 .

The promotion or communications mix. Source: Ref. ([22], p. 137). 
Despite some negative opinions in the health sector, advertising has been implemented by hospitals for many years under the headings of public relations and press and community relations. Today, such communication activities have been expanded not only to assist in the promotion of the services offered but also to carry out a training and motivation and attitude development function. As an effective means of communication, advertising should draw people facing health services to existing services while warning them against certain facts. Although there have been some criticisms of unethical practices and wasted resources, it has been successful in increasing the consumption of the services provided. If it is done in an appropriate and moral way, advertising will continue to be a powerful tool for the healthcare sector that wants to promote its services to consumers [23].

Health care is one of the sectors that has grown the most in the service sector. With increasing interest in health, advertising plays an important role in determining the market share and profitability of hospitals. Reasons for this include increased competitive pressures for hospitals, increased customer training levels, greater awareness, and better discrepancy between the qualities of service provided by different hospitals [24].

Public relations are at the forefront in terms of creating a positive image in the society in terms of services and works offered in health institutions rather than advertising in marketing communication. Health services marketing with image management, it aims to create communication programs that will enable customers to evaluate the hospital and the health services provided positively ([7], p. 253). Health institutions and staff should have the ability to communicate effectively with their customers and stakeholders. Communication can be more effective with a clear audience and when the audience's media habits are in-line with what is known. Successful communication involves nine elements of communication. These are the source, coding, message, media, decoding, receiver/viewer, response, noise, and feedback. In addition, the audience must understand the responses from awareness to knowledge, preference, taste, beliefs, and purchasing. Developing effective marketing communication consists of eight important steps. These ([25]: 426) are the following:

1. Identify the target audience: It is the determination of the audience that each marketing communication tool used by the company will reach. At the same time, the answers to the questions to what extent the target group will be reached are determined.

2. Determining communication objectives: It is sought to answer questions about how communication processes consumers, increases awareness, and improves the image of the healthcare organization.

3. Designing communication: The healthcare organization has to determine how to establish communication in order to reach its target audience. It should use well-designed communication to help customers remember the brand more easily and improve their relationship with customers. For example, it is illegal to broadcast DTC-branded drugs on Canadian television channels. However, the firm is able to strengthen the communication with its customers by advertising to the American TV channels considering that Canadians can access the TV channels in the United States.

4. Selecting communication channels: The healthcare organization should determine which channel (TV commercials, social media, brochures, billboards, 
etc.) to use to communicate with its target audience. When determining the communication channel, determining a suitable channel for the customer is very important in terms of brand recognition and retention.

5. Estimate the total marketing communication budget: The healthcare organization should determine the budget to be allocated to the tools to be used in marketing communication. For this reason, the communication medium that can reach the target audience must be in-line with the budget of the healthcare organization. Otherwise, it will be inevitable that the healthcare organization will face financial problems in the future.

6. Deciding which media channels to use: The healthcare organization can have multiple communication tools to reach its target audience. Deciding which of these communication tools to choose is very important for effective and efficient customer communication.

7. To measure the results: The measurement of the effectiveness and efficiency of the communication channels determined and applied to reach the target audience is realized at this stage.

8. Managing integrated communications: In summary, a healthcare provider should decide the best mix of marketing communication tools (advertising, personal selling, public relations, promotion, direct marketing, etc.). It should continually evaluate the decision-making methods with criteria such as awareness, interest, information, preference, and procurement. The organization should try to manage a well-integrated marketing communication program over time.

As mentioned before, personal selling is the most powerful promotion method in the service sector. Research on this subject shows that the sales process of a service depends on the quality of the relationship between the seller and the buyer. However, when used well, advertising can have more positive results than public relations. Inter-customer communication, also called word of mouth marketing, is also very important for the health sector ([7], p. 254). Healthcare companies generally prefer to use their own staff instead of professional salespeople. Should a professional sales person be trained and used in the sale of health services, or should staff such as nurses and doctors be trained in sales techniques? A complete answer to this question has not yet been found. In one view, health care is no different from other goods or services, so a person who has previously been successful in the sale of construction equipment can also be successful in this field. Another alternative is to benefit from people who have proven their ability to sell in health-related branches. Companies that produce or sell pharmaceuticals and medical supplies use many sales representatives. The medical knowledge of such a salesperson cannot be as much as a physician but it is undoubtedly more than any person [18].

Some people see physicians referring patients to the hospital as sales persons, which is wrong. The sales representative acts for the purpose of sale. However, the physician refers the patient to a higher health institution for medical reasons. The physician is free to send the patient to any organization and physician, and the seller does not have such freedom [26].

Providing health services effectively is perhaps the only way to reach healthy generations. Hospitals, which are one of the places where health services are provided, can provide these services through the integrated marketing communication efforts of the hospitals. Integrated marketing communication in the health sector is to communicate health services to potential users through communication and to 
convince them of the benefits to be achieved. Through integrated marketing communication studies, it is aimed to convey the existence, quality, access, and use of services to potential patients. Although personal selling and sales promotion activities, which play an important role in product marketing, do not have a wide application in health services, advertising and public relations can find a very important and wide application area. These subjects are explained in detail in this book ([23] p. V). The advertisement gives a reason for the purchase of the product, and the sales promotion offers an incentive for the purchase. Sales promotion includes efforts for consumer promotion such as samples, coupons, cash back, discounted prices, gifts, free trials, warranties, binding promotions, point of sale displays, and exhibitions. Commercial promotion includes discounted prices, advertising and display costs, and free items, and business and sales promotion includes commercial exhibitions and congresses, competitions for sales representatives, and special advertisements [27]. Compared to sales development activities implemented in other sectors, the methods of sales promotion in health services are very limited. However, some creative solutions can still be found. For example, patients who come to the health facility for the first time can be given a certain discount or to children who come with the patient can be given small gifts. Sales incentives applied in the health services sector can be given as a positive work, action, or attitude response. Trying, buying more, and participating in marketing effort are positive behavior. However, sometimes penalties may be imposed to prevent the opposite of a desired behavior. For example, while in some countries financial assistance is provided to families with fewer children for the purpose of population control, tax rates of families with many children have been increased [18].

Along with the difficulties arising from the abstractness of health services, health promotion strategies are as follows ([7], p. 254);

1. Ensure that employees are aware of opportunities to promote health as part of their work.

2. Provide health information to employees, visitors, and patients in order to inform them of their health decisions.

3. Support the changing behavior of individuals.

4. Beautify the environment of the health institution for its users.

5. Establish contact with other health institutions for proper planning and distribution.

6. Ensure that all marketing communication activities are research-based.

7. Evaluate the results of promotion activities.

Social media marketing in the field of health is another marketing communication tool. There are several ways in which social media can be used for health promotion education. The digitization of human interactions and intimacy has led to a distance of convergence and even disappearing at the touch of a button. As a result of digitalization, social media is a source of interaction for public health. It has the potential to change many health-related behaviors, especially in times of crisis. With the interaction in social media, multifaceted communication takes place and public health messages are spread more rapidly. As a result, health knowledge of the society increases and contributes to the development of health level ([28], p. 301). 
Consumers' widespread use of electronic tools forces marketing experts to find new technology strategies. The aim of health marketing is to learn and understand the needs and aspirations of potential patients in order to meet these requirements at the highest standards. Tools such as the Internet, social media, and e-mail provide a direct cost to direct marketing, as well as provide virtual customers with an opportunity to market the service, eliminate distances, and make consumers aware of the service provided. Another important advantage increases the ability of marketing managers in health institutions to identify target audiences by using electronic media as advertising tools in the development of marketing strategies ([29], p. 44; [30]). In a study examining the effectiveness of social media in plastic surgery marketing, researchers compared the prevalence of social media with classical marketing methods. This research was conducted in Beverly Hills, California; Dallas, Texas; Houston, Texas; Las Vegas, Nevada; Miami, Florida; New York City, New York; and San Francisco, California. Plastic surgeons in Florida prefer social media (50\% Facebook and $46 \%$ Twitter) for their promotional activities. Fifty-six percent of plastic surgeons in New York use magazines and newspapers in their promotional activities, while surgeons in Beverly Hills use television commercials. As a result, although social media seems to be a unique means of communication, it is emphasized that it is important to maintain the profession in a professional way and to create a traditional website and to maintain these activities in line with ethical principles [31].

It is always a good idea to have a good website for corporations. The fact that organizations have an interactive and user-friendly website that provides a lot of information also points to an excellent advertising platform. The website may be a source of information for potential patients, employees, or other stakeholders. Patients use the organization's websites to learn about the services provided by the healthcare provider, read user reviews, access photo and video content about the organization, and compare healthcare prices and offers with other healthcare organizations. At the same time, access to consumers is facilitated through keywords added to websites. This makes it easier to reach the target audience. The healthcare provider communicates with consumers through their website about their own or the price offers of products and services and helps the Internet user to search for the information they want and to make the dialog between consumers and the organization sustainable [32].

Advertising and promotion, which are among the promotion activities in health services, are marketing strategies aimed at developing and sustaining relations with the target group (patients). In order to carry out these activities, ethical rules are needed in health marketing. Because health services are open to abuse. Therefore, promotion activities of health institutions should be consistent and should not create unnecessary expectations for patients. Physicians or health institutions providing health services should be able to provide the health services claimed in the advertisements. A patient who is in severe pain is easily affected by advertising and will tend to rely on any promise of recovery [33].

\section{Result}

Marketing communication is done to inform consumers about whom, when, where, how, and why the product or service will be used. Through marketing communication, consumers can learn by whom the product or service is being produced and what the manufacturer or brand means. It also contributes to brand equity by increasing sales, increasing brand value, and creating brand image [1]. Organizations try to provide competitive advantage through marketing communication or promotion activities and to protect and increase their superiority. 
Although these activities are thought to be aimed at consumers, they are carried out in the works for intermediary institutions [34]. Marketing communication activities in corporations are carried out with many tools such as advertising, sales promotions, personal selling, public relations, direct marketing, and digital marketing. Promotion can be done not only in nonprofit organizations but also by nonprofit organizations and manufacturers. The main purpose of promotion in corporations is to inform, convince, and remind current or potential customers about the corporation and the products and services it produces. The result of these activities is to attract the attention of customers and realize the sale.

Due to some factors arising from consumers, the importance of promotion is increasing day by day. Some of these factors are changing the demands, needs, and expectations of consumers, increasing the number of conscious consumers; increasing competitors; increasing the number of intermediary institutions; or being in different positions of producers and consumers. However, increasing cost pressures hinder promotion activities in some cases. For this reason, it is possible to reduce the costs of promotion with technological developments in today's world. Technological advances have brought the concept of digital marketing to the agenda and traditional marketing methods have become much less used. Corporations use many digital tools such as web sites, social media, and e-mail in their promotional activities, and these modern marketing methods can reach more people at a lower cost than classical marketing. Consumers can easily find the corporation, product, or service they want to reach through search engines, and in the light of the information on their web sites, they both know the business and obtain information about the product or service. In addition, promotional activities through social media reinforce the image of the business and create a communication between the business and the consumer.

Promotion activities in health services, which are very difficult to deliver and manage within the service sector are very important. Although it is not as active as the promotion mix elements used in other sectors, advertising and public relations occupy an important and wide place in the health sector. Promotion in the health sector means to conduct the products or services presented in the healthcare facility to the potential users by using promotional tools such as advertising and public relations and convincing them about the benefits to be obtained. The aim is to provide information about the existence, quality, access, and use of services to be provided to potential patients.

In the health sector, the services provided are not only communicated to potential users but are also considered as promotions in trainings provided on social platforms in order to increase the reliability and the image of the company or serve the society. As in other sectors, promotion activities in the health sector have changed in parallel with the development of technology. In the past, the services provided by the healthcare facility were communicated to potential users through mass media such as magazines, newspapers, or TV channels, but now they communicate directly or indirectly with patients through their own web sites or social media accounts. At the same time, it is easier for healthcare organizations to communicate with their existing or potential patients through their own mobile applications developed on platforms such as Apple Store and Play Store.

The most important marketing communication tool used in health institutions is public relations. As in all other organizations, there are many groups (stakeholders) where health institutions interact. These are divided into two as internal stakeholders (employees, managers, hospital owners, etc.) and external stakeholders (patients, relatives of patients, media, Ministry of Health, competing hospitals, supplier groups, etc.). Public relations, which is one of the marketing communication tools, can be expressed as efforts to create a positive image in society by 
establishing correct and reliable relations with internal and external stakeholders. Furthermore, sharing the policies implemented by the health institution with the stakeholders and adopting these policies by the stakeholders, ensuring that the activities of the organization are positively met by the stakeholders, are among the activities of public relations. If good communication is established with the society, it is inevitable that the health institution will increase its market awareness and superiority over its competitors. For this reason, public relations, which is one of the marketing communication tools, is among the indispensable marketing activities of the health institution.

The aim of health promotion activities is not to direct existing or potential patients to unnecessary consumption but to inform them, to convince them of the benefits to be provided, and to include patients in the diagnosis and treatment process. In this way, it helps in the early diagnosis and treatment of diseases. It can also be used to provide new financial resources through donations to the organization through the efforts of the public relations unit. As a result, the promotion of the health service marketing mix, or the so-called marketing communication, is vital.

\section{Author details}

Aykut Ekiyor $^{1 *}$ and Fatih Altan ${ }^{2}$

1 Faculty of Economics and Administrative Sciences, Healthcare Management, University of Ankara Haci Bayram Veli, Turkey

2 Department of Medical Services and Techniques, Halil Bayraktar Vocational School of Health Services, University of Erciyes, Turkey

*Address all correspondence to: aykutekiyor1974@yahoo.com

IntechOpen

(C) 2020 The Author(s). Licensee IntechOpen. This chapter is distributed under the terms of the Creative Commons Attribution License (http://creativecommons.org/licenses/ by/3.0), which permits unrestricted use, distribution, and reproduction in any medium, provided the original work is properly cited. (cc) BY 


\section{References}

[1] Kotler P, Keller KL. Marketing Management. 15th Global ed. London: Pearson Education; 2016

[2] Kotler P, Armstrong G. Principles of Marketing. United Kingdom: Pearson Education Limited; 2018

[3] Perreault WD, Cannon JP, McCarthy EJ. Essentials of Marketing: A Marketing Strategy Planning Approach. 4th ed. New York: McGraw-Hill Education; 2015

[4] Keller KL. Mastering the marketing communications mix: Micro and macro perspectives on integrated marketing communication programs. Journal of Marketing Management. 2001;17(7-8):819-847

[5] Pride WM, Ferrell OC. Foundations of Marketing. 6th ed. USA: Cengage Learning; 2015

[6] Pride WM, Ferrell OC. Marketing. 14th ed. USA: Cengage Learning; 2014

[7] Tengilimoğlu D. Sağlık Hizmetleri Pazarlaması. Ankara: Siyasal Kitabevi; 2011

[8] Belch GE, Belch MA. Advertising and Promotion: An Integrated Marketing Communications Perspective. 11th ed. USA: McGraw-Hill Education; 2012

[9] Shimp TA. Advertising, Promotion, and Other Aspects of Interrated Marketing Communications. 7th ed. USA: Thomson South-Western; 2007

[10] Korkmaz S, Eser Z, Öztürk SA. Pazarlama: Kavramlar-İlkeler-Kararlar (3. Bask1). Ankara: Siyasal Kitabevi; 2017

[11] Findlay SD. Direct-to-consumer promotion of prescription drugs: Economic implications for patients, payers and providers. PharmacoEconomics. 2001;19(2):109-119

[12] Rosenthal MB, Berndt ER, Donohue JM, Frank RG, Epstein AM. Promotion of prescription drugs to consumers. New England Journal of Medicine. 2002;346(7):498-505

[13] Adeoye S, Bozic KJ. Direct to consumer advertising in healthcare. Clinical Orthopaedics and Related Research. 2007;457:96-104

[14] Fahy J, Jobber D. Foundations of Marketing. 5th ed. USA: McGraw-Hill Education; 2015

[15] Pike S. Destination Marketing: An Integrated Marketing Communication Approach. USA: Butterworth-

Heinemann; 2008

[16] Thomas RK. Health Services Marketing: A Practitioner's Guide. USA: Springer Science+Business Media, LLC; 2008

[17] Elrod JK, Fortenberry JL. Formulating productive marketing communications strategy: A major health system's experience. BMC Health Services Research. 2018;18(3):926

[18] Karafakioğlu M. Sağlık Hizmetleri Pazarlaması. İstanbul: İstanbul Üniversitesi İşletme Fakültesi Yayın No: $271 ; 1998$

[19] Kirdar Y. The role of public relations for image creating in health services: A sample patient satisfaction survey. Health Marketing Quarterly. 2008;24(3-4):33-53

[20] PhillipsBJ, McQuarrieEF. Contesting the social impact of marketing: A re-characterization of women's fashion advertising. Marketing Theory. 2011;11(2):99-126 
[21] Sreenivas T, Srinivasarao B, Rao US. An analysis on marketing mix in hospital. International Journal of Advanced Research in Management and Social Sciences. 2013;2(4):187-207

[22] Gilligan C, Lowe R. Marketing and Health Care Organizations. CRC Press, Taylor \& Francis Group; 2016

[23] Karaca Ş. Sağlık Hizmetlerinde Pazarlama: Bütünleşik Pazarlama İletişimi Yaklaşımıyla. İstanbul: Beta Yayıncılık; 2015

[24] Andaleeb SS. Determinants of customer satisfaction with hospitals: A managerial model. International Journal of Health Care Quality Assurance. 1998;11(6):181-187

[25] Kotler P, Shlowitz J, Stevens RJ. Stratejic Marketing for Health Care Organizations: Building a CustomerDriven Health System. USA: John Wiley \& Sons; 2008

[26] Kotler P, Clarke RN. Marketing for Health Care Organization. New Jersey: Prentic-Hall Inc.; 1987

[27] Kotler P. Marketing Management (Millennium Edition b.).

(N. Muallimoğlu, Çev.). İstanbul: Beta Yayınc1lı; 2000

[28] Gupta A, Tyagi M, Sharma D. Use of social media marketing in healthcare. Journal of Health Management.

2013;15(2):293-302

[29] Radu G, Solomon M, Gheorghe CM, Hostiuc M, Bulescu IA, Purcarea VL. The adaptation of health care marketing to the digital era. Journal of Medicine and Life. 2017;10(1):44-46

[30] Copley P. Marketing

Communications Management:

Concepts and Theories, Cases and Practices. Routledge (Taylor\& Francis Group); 2004
[31] Wong WW, Gupta SC. Plastic surgery marketing in a generation of “tweeting”. Aesthetic Surgery Journal. 2011;31(8):972-976

[32] Masterman G, Wood EH. Innovative Marketing Communications: Strategies for the Event Industry. Routledge; 2006

[33] Maria S, Gabriel R, Marinela H, Madalin MM, Alexandru BI, Lorin PV. Ethical issues in advertising and promotion of medical units.

Romanian Journal of Ophthalmology. 2016;60(4):216-218

[34] Gümüş S. Sağlıkta İlaç Pazarlaması: Araştırma, İnceleme, Mülakat, Yorum, Sonuç ve Değerlendirmeler. İstanbul: Hiperlink Yayınları; 2014 


\section{Edited by Umut Ayman and Anıl Kemal Kaya}

This edited Promotion and Marketing Communications book is an original volume that presents a collection of chapters authored by various researchers and edited by marketing communication professionals. To survive in the competitive world, companies feel an urge to achieve a competitive advantage by applying accurate marketing communication tactics. Understanding marketing communication is an essential aspect for any field and any country. Hence, in this volume there is the latest research about marketing communication under which marketing strategies are delicately discussed. This book does not only contribute to the marketing and marketing communication intellectuals but also serves different sector company managerial positions and provides a guideline for people who want to attain a career in this field, giving them a chance to acquire the knowledge regarding consumer behavior, public relations, and digital marketing themes.

Published in London, UK

\section{IntechOpen}
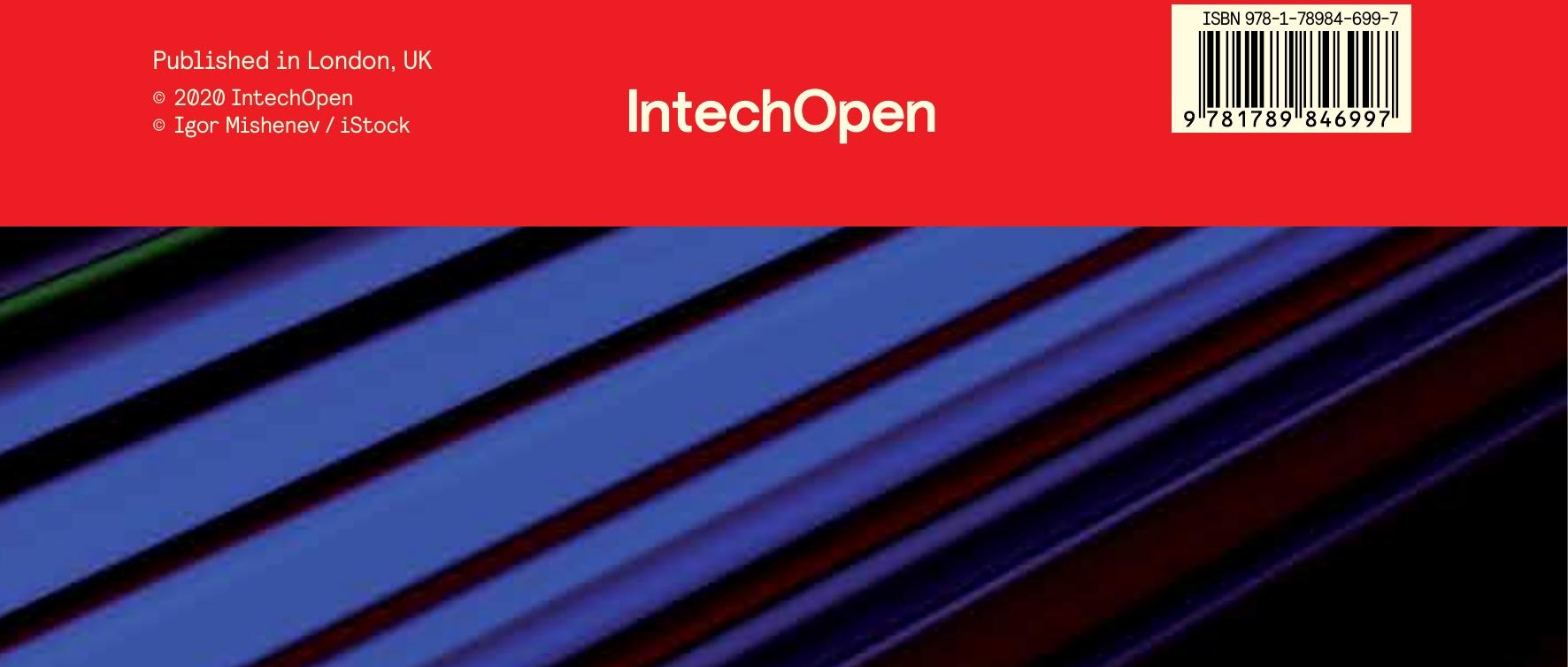